Universidade de São Paulo

Faculdade de Filosofia, Letras e Ciências Humanas

Departamento de Sociologia

FÁTIMA ANTUNES DA SILVA

\title{
A IMAGEM POÉTICA DO NUEVO TEATRO LATINO- AMERICANO: O CASO DO TEC e LA CANDELÁRIA
}

Tese apresentada ao Departamento de Sociologia da Faculdade de Filosofia, Letras e Ciências Humanas da Universidade de São Paulo, como exigência para a obtenção do Título de Doutor em Sociologia.

Orientador: Prof. Dr. Sedi Hirano 
BANCA EXAMINADORA 
Aos meus queridos pais, Aurene Maria Antunes da Silva

e David Ferreira da Silva 


\section{AGRADECIMENTOS}

Foram muitas as pessoas, organizações e instituições que tornaram essa tese possível. Agradeço a todos que de forma direta ou indireta contribuíram para o trabalho. Um agradecimento muito especial para:

Professor Doutor Sedi Hirano, Orientador e Mestre.

Professores Drs. Dilma de Melo e Verônica

Professores Dr. Claudia Montilla e Beth Osório, do Departamento de la Universidad de los Andes

Jacqueline Vidal, diretora do TEC - Teatro Experimental de Cali (Cali, Colômbia)

Santiago Garcia, Diretor do La Candelária (Bogotá, Colômbia)

Ângela e Irani, da Secretaria de Pós-Graduação da Sociologia

Nomes: Funcionários da Biblioteca da FFLCH

Aos meus alunos das disciplinas Nuevo Teatro Colombiano, Teoria da Encenação e InterpretaçãoII: Gaby, Monique, (...) 


\section{LA POESÍA ES UN ATENTADO CELESTE}

Yo estoy ausente pero en el fondo de esta ausencia

Hay la espera de mí mismo

Y esta espera es otro modo de presencia

La espera de mi retorno

Yo estoy en otros objetos

Ando en viaje dando un poco de mi vida

A ciertos árboles y a ciertas piedras

Que me han esperado muchos años

Se cansaron de esperarme y se sentaron

Yo no estoy y estoy

Estoy ausente y estoy presente en estado de espera

Ellos querrían mi lenguaje para expresarse

$Y$ yo querría el de ellos para expresarlos

He aquí el equívoco el atroz equívoco

Angustioso lamentable

Me voy adentrando en estas plantas

Voy dejando mis ropas

Se me van cayendo las carnes

$\mathrm{Y}$ mi esqueleto se va revistiendo de cortezas

Me estoy haciendo árbol Cuántas cosas me he ido convirtiendo en

[otras cosas...

Es doloroso y lleno de ternura Podría dar un grito pero se espantaría la transubstanciación Hay que guardar silencio

Esperar en silencio

(Vicente Huidobro, poeta chileno) 


\section{RESUMO}

O objetivo do presente trabalho foi desenvolver um estudo sobre a imagem poética do Nuevo Teatro Latino-Americano. A análise desenvolvida, a partir do ponto de vista da Sociologia da Arte, buscou o deslindamento dessa imagem nas encenações teatrais representativas dos principais grupos do movimento: TEC e LA CANDELÁRIA da Colômbia.

Parte-se de uma primeira hipótese de que essa imagem poética repousa sobre princípios que remontam às vanguardas do início do século XX. Parte-se de uma segunda hipótese de que encenadores de parte das obras teatrais representativas do movimento do Nuevo Teatro, para além de seu engajamento sócio-político já constatado, empreenderam, consciente ou inconscientemente, uma busca estética que pode dialogar em muitos pontos com a vanguarda russa do século XX. Experiência em que vigorou de forma orgânica a confluência entre vanguarda artística e vanguarda política. Por meio de múltiplos caminhos, alguns não aparentes e subterrâneos, pode-se afirmar, que houve influências de princípios do teatro de vanguarda russo, mais precisamente do teatro de Meyerhold, sobre o Nuevo Teatro, evidentes nas imagens cênicas construídas em suas obras teatrais.

A partir da violência e barbárie da Conquista, as sociedades da América Latina foram se configurando sob o signo da fragmentação, o que gerou desde sua origem a busca pela unidade do Ser. O alcance da criação de imagens poéticas de sua produção teatral da segunda metade do século XX revela um relativo amadurecimento desta busca. Representa não um ponto de chegada propriamente dito, mas uma aproximação ao reconhecimento do que significou, significa e significará ser latino-americano. 


\section{ABSTRACT}

This work intends to develop a study on the poetical image of the "Nuevo Teatro Latino-Americano”. From the Sociology of the Arts point of view the analysis sought to explicate this image in the theatrical presentations representative of the main groups of the movement: TEC and the Colombian LA CANDELÀRIA.

The first hypothesis surmises that this poetical image rests upon principles that go back to the vanguards of the early $20^{\text {th }}$ Century. A second hypothesis considers that those staging part of the theatrical works representative of the Nuevo Teatro movement, in addition to their already detected social-political commitment, consciously or unconsciously pursued an esthetical quest able to establish a wide ranging dialogue with the Russian vanguard of the $20^{\text {th }}$ Century. An experience that strengthened in an organic manner the confluence between the artistic and the political vanguards. Through multiple routes, some not apparent and subterranean, it can be stated that the Russian vanguard theater principles, more precisely, the Meyerhold theater had an influence, on the Nuevo Teatro, clearly seen in the scenic images constructed in their theatrical works.

After the violence and barbarism of Conquest, Latin American societies were being shaped under the sign of fragmentation which generated, as from their origin, the quest for unison of the Being. In the second half of the $20^{\text {th }}$ Century, the scope of the Nuevo Teatro poetical image creation discloses a relative maturity of this quest. It does not embody a true point of arrival, but an approximation to the acknowledgment of what it meant, means and will mean to be Latin-American. 


\section{LISTA DE ABREVIAÇÕES DE INSTITUIÇÕES CULTURAIS}

ALCA - Associação de Livre Comércio das Américas

ASONATU - Asociación Nacional de Teatro Universitario

ANUC - Asociasión Nacional de Usuários Campesinos

C.C.T. - Corporação Colombiana de Teatro

CAN - Comunidade Andina de Nações

CLETA - Centro Libre de Experimentación Teatral y Artística (México)

I.C.C. - Instituto Colombiano de Cultura

Cocultura - Instituto Colombiano de Teatro

I.T.I. - Instituto Internacional de Teatro da Unesco (1957)

OIC - Organização Internacional do Café

T.E.C - Teatro Escuela de Cali

TEC - Teatro Experimental de Cali

TENAZ - Teatro Nacional de Aztlán (Estados Unidos)

TIAR - Tratado Inter-americano de Assistência Recíproca

TLC - Tratado bi-lateral de Livre Comércio 


\section{SUMÁRIO}

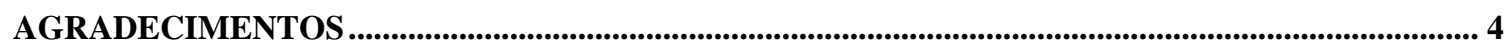

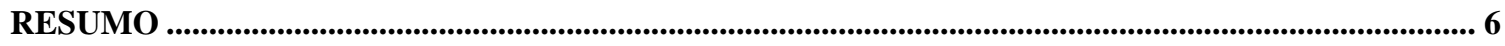

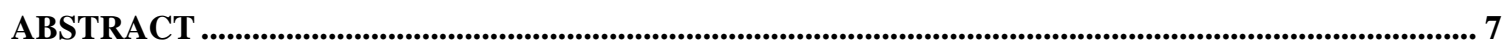

LISTA DE ABREVIAÇÕES DE INSTITUIÇÕES CULTURAIS........................................................... 8

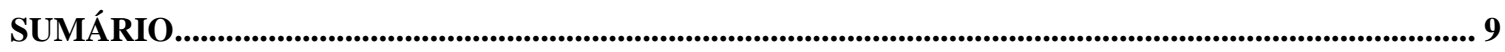

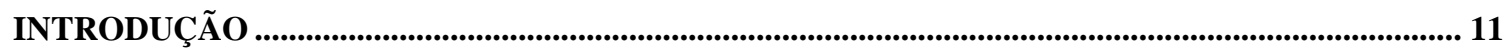

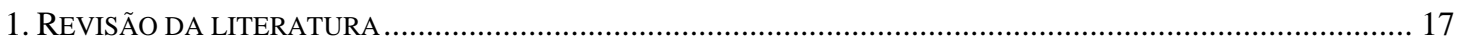

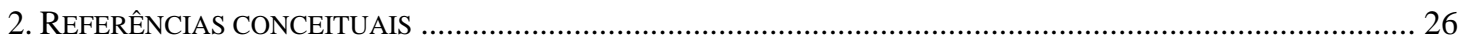

1. O ponto de vista da Sociologia ........................................................................................................ 26

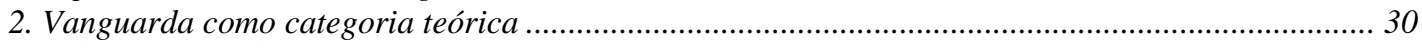

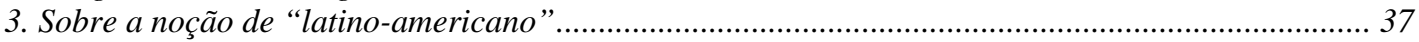

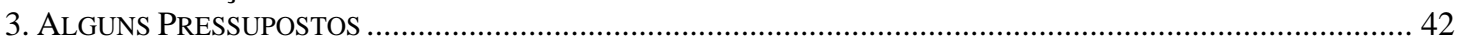

1. O Nuevo Teatro como a primeira vanguarda teatral latino-americana ........................................ 42

2. Vinculação a uma estética socio-política ..................................................................................... 44

3. Cultura de resistência e continuidade cultural ............................................................................... 52

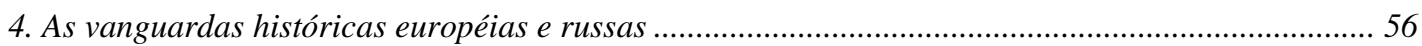

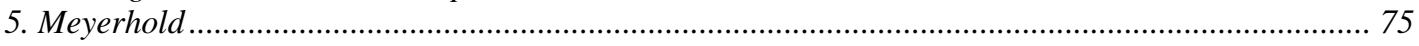

I. ANTECEDENTES HISTÓRICO E POLÍTICO DO NUEVO TEATRO COLOMBIANO .................91

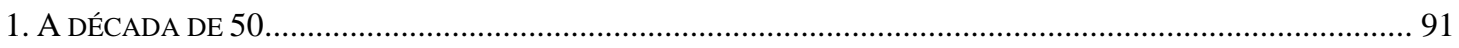

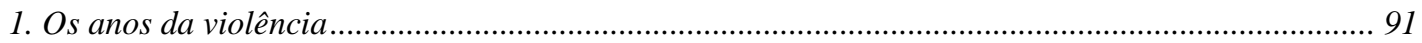

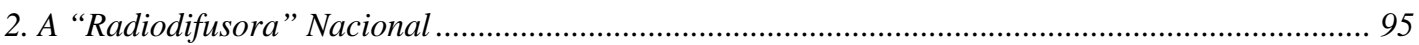

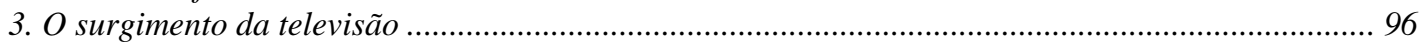

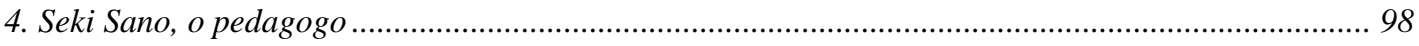

Seki Sano na Colômbia ........................................................................................................................................100

Seki Sano: ponte entre América Latina e "União Soviética” / Ponte entre Nuevo Teatro e Vanguarda Russa.104

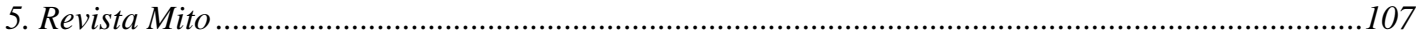

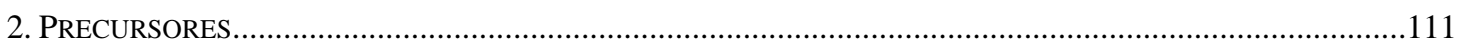

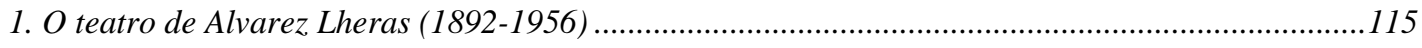

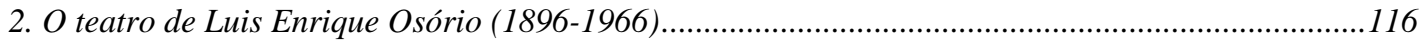

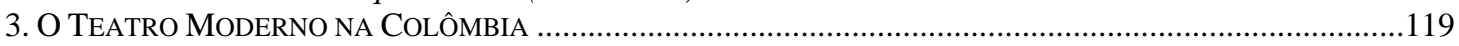

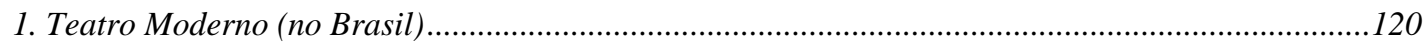

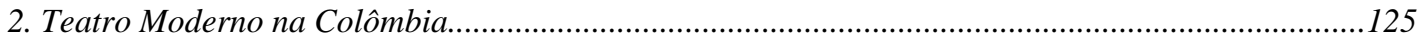

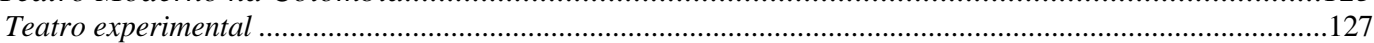

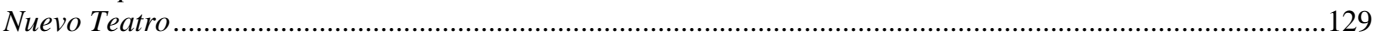

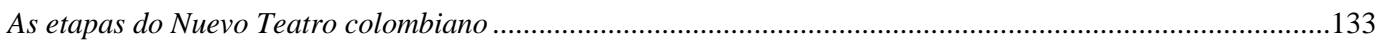

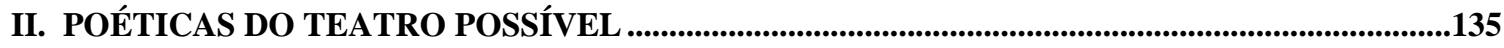

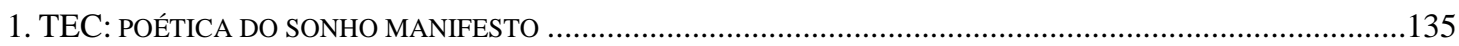

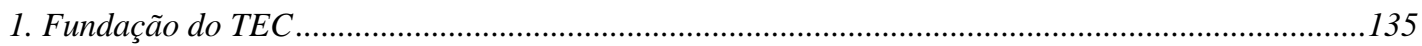

2. Personalidade de Enrique Buenaventura (1925-2003): ...............................................................135

3. Primórdios de sua Teoria Teatral..............................................................................................137

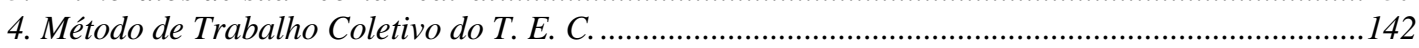

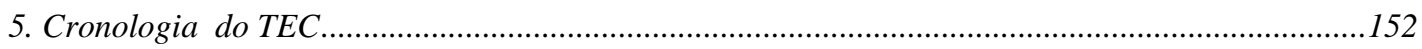


2. LA CANDELÁRIA: AS ALTURAS DO VÔO POÉTICO .............................................................................155

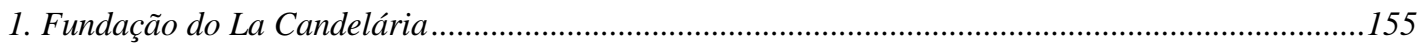

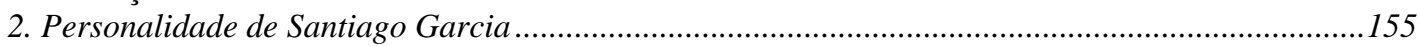

3. Sua Concepção Teatral ....................................................................................................................159

Nosotros los comunes - a primeira criação coletiva do La Candelária................................................163

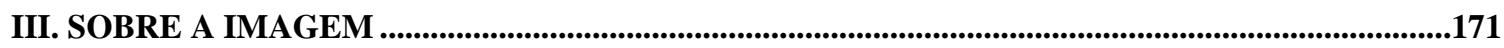

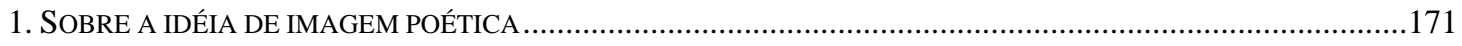

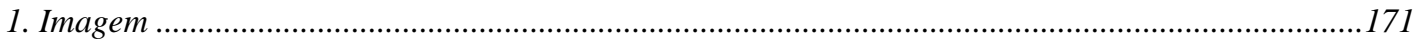

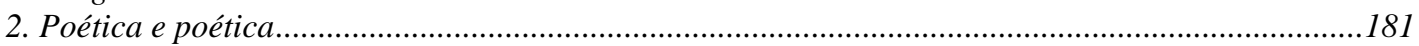

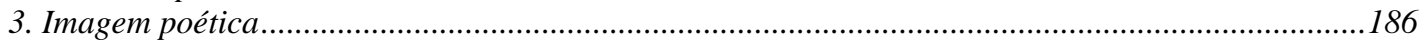

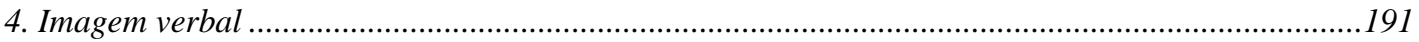

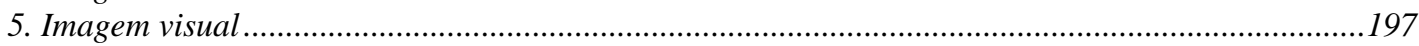

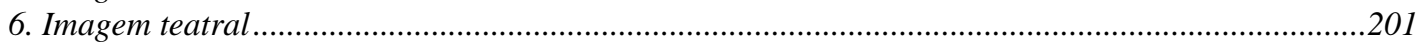

7. A imagem poética do Nuevo Teatro .......................................................................................208

IV. A IMAGEM POÉTICA DO NUEVO TEATRO.........................................................................211

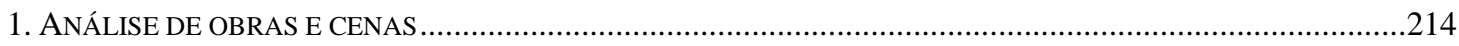

1. A imagem poética do TEC ......................................................................................................216

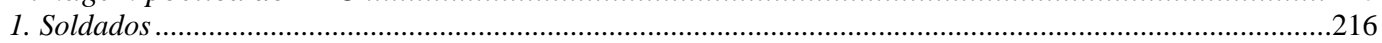

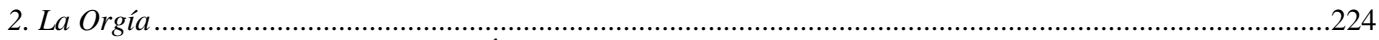

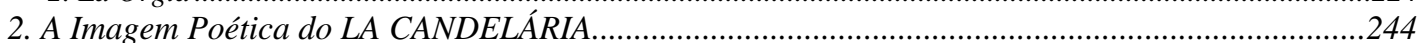

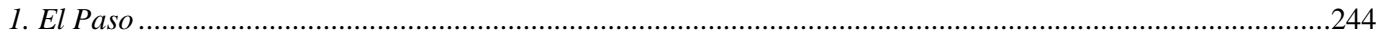

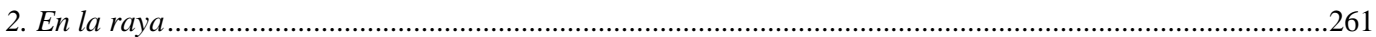

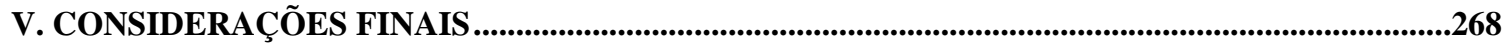

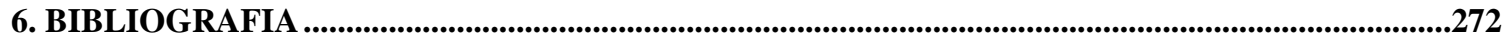

1. OBRAS DE E SOBRE ENRIQUE BUENAVENTURA E O TEATRO EXPERIMENTAL DE CALI.............................272

2. OBRAS DE E SOBRE SANTIAGO GARCIA E O TEATRo LA CANDELÁRIA ................................................272

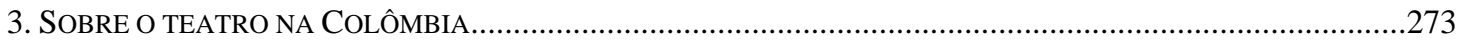

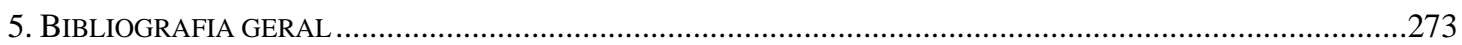

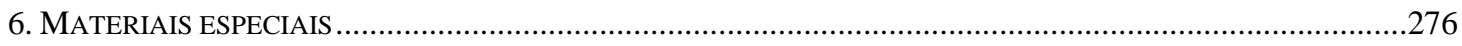

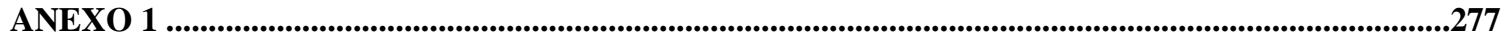

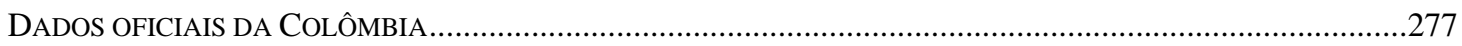

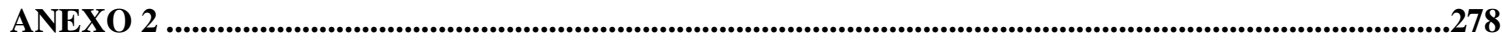

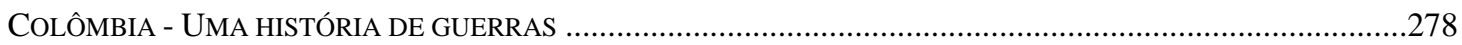

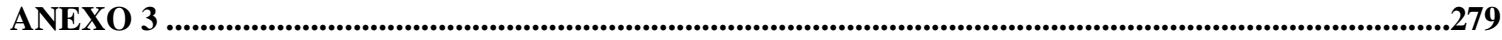




\section{INTRODUÇÃO}

Este trabalho trata do desenvolvimento da imagem poética do Nuevo Teatro Latino-Americano, movimento que teve suas origens em 1955, seu auge em 1965-1975, atravessou os anos 80-90 por meio de seus contínuos desdobramentos, estendo-se até os dias atuais (2007). O foco principal não é a história do movimento nem o seu caráter de teatro comprometido socio-politicamente, aspectos já explorados por diversas análises, mas, ao invés disso, trata-se antes de identificar, nos textos teóricos e nas encenações dos principais artistas do movimento, pistas que deixam entrever uma preocupação com a construção poética da cena, uma faceta das produções teatrais do Nuevo Teatro que tem sido menosprezada, quando não negada em prol de um entendimento tornado lugar comum concernente ao seu engajamento político. Objeto de inúmeras investigações, este aspecto político do Nuevo Teatro acabou se tornando uma espécie de rótulo: uma etiqueta, que só fez obscurecer suas múltiplas implicações, sua complexidade, e por fim seus limites. Paralelamente a este engajamento político, todavia, o Nuevo Teatro perseguiu e buscou continuamente uma forma poética, no sentido de promover na cena uma certa poesia, uma imagem esteticamente elaborada. É sobre esta busca estética pautada em seu engajamento sócio-político que este trabalho se debruçou. Essa busca de uma poesia da cena, ou de uma poética política, pode ser facilmente detectada nos textos e no âmbito da teoria produzida no Nuevo Teatro pelos diretores de ao menos dois dos principais grupos do movimento colombiano: Enrique Buenaventura e Santiago Garcia; mas, se a objetivação desta busca chegou efetivamente à cena, se sua realização cênica foi alcançada, trata-se de uma das questões a que se propõe investigar o presente trabalho.

É preciso lembrar que não se trata de nenhuma inovação do Nuevo Teatro essa articulação entre teatro engajado e pesquisa estética. O debate sobre a relação entre Arte e Política de um lado e Arte Pura do outro é obra do início do processo de "autonomização" da arte de meados do século XIX na Europa, em que a Literatura se destacou como pioneira nessa reflexão, de acordo com a análise de Bourdieu. O acirramento do debate vai desembocar no equívoco do realismo socialista na Rússia dos anos 30 (séc. XX), mas ele surge também na ambigüidade das proposições vanguardistas. De todo modo, há pelo 
menos um momento da história do teatro europeu em que a vinculação entre teatro engajado e pesquisa estética vai resultar numa completa revolução e inovação na produção de obras de arte. Tratam-se dos anos 20 da Rússia e da Alemanha: Meyerhold, Piscator e Brecht, no teatro; mas também experiências similares no âmbito das Artes Plásticas, da Literatura, Cinema, e Música, ocorreriam numa vinculação nunca tão produtiva.

E, paradoxalmente, pode-se afirmar que essa vinculação entre teatro engajado e busca estética do Nuevo Teatro foi resultado sim de uma inovação sob vários aspectos. No contexto do teatro mundial, foi produto dos ventos vanguardistas europeus e russos que aportavam de diversas formas na região; no contexto da América Latina, foi uma inovação e renovação da arte jamais vista, resultante num primeiro momento, do desejo da classe burguesa e industrial recentemente alçada ao poder dominante, de se antenar com o que de mais “moderno” acontecia na Europa e EUA em termos de produção artística.

Todavia, o que pode ser considerado efetivamente inovação nessa história toda é essa abordagem do Nuevo Teatro. Apropriando-se do amplo estudo feito sobre o seu caráter de teatro comprometido e engajado sócio-politicamente, e associando-o a uma outra linha menos explorada do Nuevo Teatro, aquela da preocupação com a busca formal, é possível traçar um paralelo do Nuevo Teatro com as vaguardas artísticas, não as da Europa, mas aquelas da Rússia das duas primeiras décadas do século $\mathrm{XX}$, onde a convergência entre vanguarda política e vanguarda artística produziu um teatro dos mais avançados esteticamente. A partir destes pressupostos, pode-se afirmar que a imagem poética do Nuevo Teatro Latino-Americano foi construída com base nessa macro-matriz estética que foram os movimentos das vanguardas artísticas, cujo desdobramento na América Latina vai conduzir a outra grande matriz estética: a do teatro precolombiano e colonial. São, por fim, estas as duas macro-matrizes configurantes da poética do Nuevo Teatro, em que o tratamento da imagem teatral será uma preocupação constante.

O objetivo do presente trabalho foi exatamente recuperar essa preocupação com a pesquisa estética por parte de seus principais expoentes, bem como refletir sobre a sua objetivação ou não no palco propriamente dito, ou seja, na própria encenação das obras. Obviamente, esse propósito encerra inúmeras dificuldades. É muito frágil tentar analisar a encenação de um espetáculo ocorrido há mais de 40 anos atrás, por meio de parcos registros. Esse é um dado limitante da pesquisa. Ora, o teatro é uma arte efêmera, o 
máximo que se pode conseguir são relatos dos que assistiram aos espetáculos, dos produzidos pelos críticos ou pelo próprio criador da obra. Em vista destas dificuldades, foram selecionadas para análise obras, que por sua importância atraíram mais olhares críticos e por isso detêm um acervo maior de textos e documentos sobre a sua encenação e execução. Mas, a preferência recaiu mesmo sobre aquelas obras que foram registradas em vídeo. É certo que o vídeo jamais conseguirá dar a totalidade do que foi o espetáculo ao vivo; mas mesmo assim, dos tipos de registros existentes, é o mais eficaz para captar algo daquela realidade criada no palco, de seu tempo fictício, específico e, principalmente, consegue fixar as imagens em seu movimento, o que a fotografia não pode fazer (o que não impede que a fotografia também seja usada como documento de referência). A possibilidade do acesso ao movimento dos atores em cena, imagem a imagem, através do vídeo, faz do "teatro filmado" o principal instrumento de apoio da análise das peças selecionadas, ao permitir detectar nelas o que poderia ser considerado uma imagem poética.

Este trabalho pode ser entendido também como uma tentativa de resposta a dois artigos particularmente reveladores da problemática do Nuevo Teatro. O primeiro se refere ao artigo de Franklin Rodríguez, “Apuntes para una Poética del Teatro Latinoamericano”, publicado em 1989, na compilacção de uma obra chamada Semiótica y Teatro Latinoamericano, resultado do I Colóquio Internacional, realizado em junho de 1989, em Kiel (Alemanha), promovido pelo Instituto Internacional de Teoría y Crítica de Teatro Latinoamericano (IITCTL); órgão criado em 1987 com o propósito de ser um espaço dedicado à reflexão e à pesquisa sobre o teatro latino-americano. Já o segundo, refere-se ao artigo de Claudia Montilla, “Del Teatro Experimental al Nuevo Teatro, 19591975”, publicado na Revista de Estúdios Sociales, em 2004, no contexto de um movimento de revisão crítica por que passa todo o período explosivo dos anos 60-70 na América Latina. A proposta do surgimento de uma especificidade do Teatro LatinoAmericano a partir do Nuevo Teatro de Franklim Rodríguez de um lado, e, de outro, a crítica à suposta ausência de pesquisa estética do Nuevo Teatro de Claudia Montilla, refletem dois aspectos de uma problemática emergida junto com o surgimento do próprio movimento. O primeiro condensa um desejo generalizado de reconhecimento por parte da crítica internacional do valor e da autenticidade do Teatro Latino-Americano. O segundo, 
condensa um desejo velado mas também geral de necessidade de discussão e reflexão mais aprofundadas sobre os reais alcances e limites do Movimento, para a sua posterior superação e avanço. Ambos os artigos, mais do que respostas, apresentam questões pertinentes, ainda em aberto, sobre o real significado dessa experiência singular do Nuevo Teatro, que pode ser entendido também como expressão de uma relativa maturidade das nações e dos povos latino-americanos.

Cabe lembrar que o ponto de onde parte o olhar do pesquisador ao produzir este trabalho é resultado de uma trajetória, cujo ritual de passagem, remonta à descoberta do aspecto profundamente transgressor e revolucionário da arte teatral. A eficácia do teatro para promover a libertação do indivíduo e seu desenvolvimento crítico com relação a sua realidade parece ser a verdadeira face da temida subversão do teatro. Isso com relação tanto aos atores quanto aos espectadores.

O movimento em direção ao Teatro Latino-Americano foi conseqüência de um processo de tomada de consciência em que a prática e o envolvimento com o teatro, junto com a formação acadêmica, puderam propiciar. O interesse pelo Teatro Latino-Americano foi se plasmando devagar, de modo que, no curso de Mestrado, essa tendência tomou forma com mais nitidez. Como resultado, foi defendida em 2002 a Dissertação: Manifestações contemporâneas do teatro político: estudo da produção e da poética da Companhia do Latão e do El Galpón (Brasil e Uruguai), orientada pelo Prof. Dr. Sedi Hirano, no Programa de Integração da América Latina da Universidade de São Paulo. O desenvolvimento da presente tese atesta a continuidade do interesse no aprofundamento das questões referente à arte e ao teatro latino-americanos.

Em razão disso, o “de onde se fala” deste trabalho pode ser resumido do seguinte modo: se se pudesse subdividir o mundo em graus de periferia, onde alguns seriam mais, outros menos periféricos, poder-se-ia situar este "ato de escritura" como sendo a partir de um locus três vezes periférico: a periferia do bloco, do país, e da cidade do interior dentro do país. E com relação ao "sobre o que se fala” não deixa de ser também um fenômeno da “periferia”. (Não se está estudando um grupo de teatro europeu como ainda é costume fazer, mas da Colômbia, um país latino-americano, portanto, periférico).

Refletir sobre o seu lugar no mundo está intimamente relacionado com o seu lugar de origem, seu bairro, sua cidade, seu país, sua história e seu modo de vida. A tomada de 
consciência de um indivíduo pode ser desencadeada de muitas e variadas maneiras. Às vezes, a experiência de uma dada situação da vida cotidiana basta para dar impulso a esse processo; outras vezes, uma peça de teatro, uma música, poema, ou determinada cena de um espetáculo, podem despertar de súbito esse processo interno que, uma vez iniciado, não tem mais fim.

Como latino-americanos, há que se mergulhar nos problemas e na reflexões produzidas localmente. Há que se mergulhar no passado para conhecer o presente e enfrentar o trauma que pesa na alma da América Latina. De certo modo, parece ser precisamente este o projeto a que a América Latina se lançou, ao menos no curso da segunda metade do século XX, o projeto de seu auto-conhecimento. Assim, este trabalho não deixa de ser também em seu cerne um processo de auto-conhecimento. Essa insistência em afirmar o ponto de vista periférico não se deve de a algum complexo de inferioridade nem a uma prévia justificativa de eventuais e potenciais problemas ou equívocos no decorrer da tese, passível de ocorrer em toda tentativa de interpretação; antes, pelo contrário, deve-se à necessisade de afirmar apenas que faz muita diferença para o trabalho a consciêntização do lugar de onde se fala, o que se fala e para quem se está falando. Sendo assim, fala-se neste trabalho “desde” la periferia, “desde” América Latina; fala-se de fenômeno artístico também da América Latina; e, por fim, fala-se aos latinoamericanos, cuja maioria por determinação do padrão de dominação, não conhece a própria história nem a própria arte. Fala-se aos estudantes, aos artistas, aos amadores da arte e, enfim, a todos quantos desejam conhecer sua própria origem.

Voltando ao tema do trabalho, vale enfatizar que a ênfase no aspecto engajado do Nuevo Teatro por parte da grande maioria dos pesquisadores acabou por deixar espaços por explorar, como por exemplo, aquele relacionado à matéria poética. Sem abrir mão do aspecto político do Movimento já constatado por inúmeros estudos, afirma-se neste trabalho que o Movimento do Nuevo Teatro foi maior do que seu próprio engajamento político, que ele se debruçou sobre a questão da pesquisa estética, da elaboração mais refinada da obra de arte, numa tendência que tem muito haver com aquela da vanguarda russa, teatral e revolucionária.

Delimitou-se aqui a tratar da experiência de um único país latino-americano: a Colômbia, por entender que esse país desempenhou um papel central na configuração do 
que veio a ser chamado mais tarde de movimento do Nuevo Teatro Latino-Americano". A Colômbia foi reconhecida pela maioria de seus vizinhos e por entidades internacionais como a vanguarda do teatro na América Latina, em virtude dos avanços, das inovações, e das questões que o seu teatro foi capaz de levantar na época, alterando definitivamente o “mapa” local do teatro, uma experiência sem precedentes na história do teatro latinoamericano.

Nesse sentido, é possível encontrar bastante material de registro e documental sobre estas práticas. A ironia, entretanto, refere-se ao isolamento em que se vêm envolvidos os países da região, principalmente o Brasil, ilhado entre os países de fala hispânica. Por isso, embora haja a prática da teorização, reflexão e publicação, é evidente a dificuldade de acesso a esse material por parte de estudantes brasileiros. Muitas vezes, acontece também a não reedição de obra mais antiga, dificultando ainda mais o acesso a ela.

Definido um conjunto de obras essenciais para a pesquisa, o passo seguinte foi o de conseguir acesso à leitura dessas obras. Como o objeto específico dessa pesquisa refere-se, em uma de suas fases, à reconstrução histórica do movimento "el nuevo teatro latinoamericano", originado na Colômbia na década de 60-70, o grupo de obras referentes a esse processo contempla tanto textos produzidos na época, com reflexões feitas no calor dos acontecimentos, quanto obras posteriores que se propunham a uma revisão crítica do processo. Com relação às primeiras, contemporâneas da origem e crescimento do movimento, muitas se encontram esgotadas ou com poucos exemplares nas bibliotecas, o que dificultou um pouco o trabalho. Mesmo as obras mais atuais, publicadas na década de 90, não são menos difíceis de encontrar para compra. De modo que foi necessário recorrer a um instrumento, cuja eficácia tem se comprovado a cada dia: a Internet. Por meio dela, foi possível o acesso a diversas obras raras e esgotadas. A Universidade de los Andes de Bogotá conta com um sistema de digitalização* de obras antigas à disposição do estudioso em qualquer parte do mundo. $\mathrm{O}$ acesso a este acervo resolveu parte dos problemas relativos à obtenção de obras referentes ao tema. De qualquer modo a viagem de campo foi fundamental para completar tanto a bibliografia quanto informações e percepções sobre a realidade do funcionamento dos grupos no momento presente. 
Enfim, o que interessa neste trabalho é a imagem poética produzida no teatro engajado social e politicamente que tem vigorado desde os primórdios do Nuevo Teatro e tem perpetuado em seus contínuos desdobramentos.

\section{Revisão da literatura}

É recente a legitimação acadêmica do campo do Teatro Latino-americano como objeto digno de ser levado em consideração por parte tanto de estudiosos das universidades estrangeiras quanto dos estudiosos de universidades locais. Por isso, a partir de 1990, tornase possível encontrar no estrangeiro obras relacionadas a este assunto, como as que se propuseram a cobrir toda a história dos fenômenos teatrais na região. Caso das publicações de Judith Weiss (1993), Adam Versényi (1993) e Eleana de Costa (1992), cujos títulos prometem amplas análises como "Latin american Popular Theatre: the first five centuries", “Theatre in Latin America: Religion, politics, and culture from Cortés to the 1980s” e ainda “Collaborative Latin American Popular Theatre”, respectivamente. Críticas à parte, em virtude da "impossibilidade" de um empreendimento de tal magnitude, o que se comprova são as contribuições efetivas destas tentativas do olhar estrangeiro em compreender a pluralidade e a contingência dessas produções teatrais.

Cada um deles, a partir de seu posicionamento com relação à definição e à função do teatro numa sociedade, estabelece os critérios de sua própria compreensão.

Desse modo, é-se defrontado com pressupostos, segundo os quais, a arte do teatro incluiria em seu universo formas tais como “dança-drama”, “ritual-drama” e "formas préteatrais”1 não apenas porque "constituiriam as origens do teatro popular nas Américas, mas também (...) porque muitos podem de fato por si mesmos serem classificados como teatro (Weiss, 1993, p.12)²; ou o "teatro da libertação”, cujas raízes são investigadas, mediante a indagação das "interconexões" que poderiam ser encontradas entre "religião, política, e teatro em regiões selecionadas e numa estrutura de tempo que vai dos dias pré-colombianos

\footnotetext{
${ }^{1}$ Cf. Weiss, op. cit., p.12: “...dance drama, ritual drama, e pretheatrical forms...”.

${ }^{2}$ Weiss reconhece que esse tipo de manifestação ritualística é contestada como forma teatral. Nessa mesma página 12, ela afirma: "The types of culture with wich we are dealing have contributed theatrical forms or types of performance whose legitimacy as such is sometimes challenged”.
} 


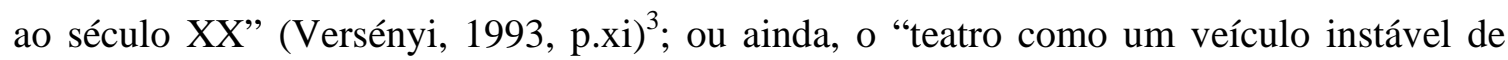
expressão", capaz tanto de esclarecer quanto de obscurecer os problemas confrontados na realidade, instrumento tanto para mistificar a vitimação quanto para dar cabo dela” (De Costa, 1992). Como uma alternativa ao obscurantismo, De Costa propõe em sua obra a idéia de "teatro colaborativo", para a compreensão da qual, aplica a filosofia pedagógica de Paulo Freire (Pedagogia do Oprimido) somada a conceitos como a do "teatro do oprimido" de Augusto Boal, de modo a tornar compreensível um “espaço dramático”, concebido como um "lugar de comunhão”, no qual "os oprimidos tomam consciência da injustiça de sua situação difícil e [são] encorajados a iniciar um caminho longo e complexo para a própria libertação"4.

Os três giram em torno de questões centrais para a compreensão do fenômeno teatral: a questão do ritual, do teatro "popular", do seu caráter "libertador", e do que consistiria a especificidade do teatro latino-americano. Enquanto Weiss e Versényi insistem numa espécie de catalogação diacrônica das manifestações teatrais, construindo uma história social do teatro latino-americano desde as práticas místico-ritualísticas dos povos do período pré-colombiano até as formas teatrais revolucionárias e neo-vanguardistas dos anos 60-70, De Costa foca seu estudo apenas nessas experiências teatrais pós-anos 50. É compreensível que, embora partam de perspectivas distintas, haja muitos pontos de contato entre os três: conceitos como o de "libertação", por exemplo, é resultado tanto da análise de Versényi quanto de De Costa.

No prefácio da obra de Weiss, fica-se sabendo da amplitude do projeto que deu origem ao livro. Trata-se do "primeiro estudo cooperativo, publicado pela ATINT Research

\footnotetext{
${ }^{3}$ A obra de Versényi, Theatre in Latin American, foi traduzida para o espanhol, de modo que as referências a essa obra contará com cotejo entre as duas. Cf.: citação traduzida no corpo do trabalho confrontada com a da obra na língua original: "This book addresses the roots of liberation theatre by investigating the interconnections of religion, politics, and theatre in selected regions and time-frames from pre-Columbian days to the twentieth century”; e ainda a tradução espanhola: “...El presente libro investiga las raíces del Teatro de la Liberación mediante la indagación de las interrelaciones que pueden hallarse entre la religión, la política y el teatro, em marcos concretos de tiempo y espacio que se extiendem desde los tiempos precolombianos hasta el actual siglo XX” (1996, p.ix).

${ }^{4}$ Collaborative Latin American Popular Theatre: From Theory to Form, From Text to Stage: “Theatre can be an unstable vehicle for expression, as capable of obscuring problems as it is of clarifying them, as instrumental in mythifying victimization as in working to end it” (p.xi). E ainda: “...I haven chosen to take a different approach to the study of the popular theatre phenomenon by the application of the pedagogical philosophy of Paulo Freire in his Pedagogy of the Oppressed and other works and the dramatic theoretician Augusto Boal's dramatic concepts as espoused in his Theatre of the Oppressed.
} 
Collective”, instituída em 1986, num esforço da Social Sciences and Humanities Research Council of Canada. “A natureza coletiva da pesquisa, do planejamento, e da escritura faz dela, tanto quanto sabemos, o primeiro projeto do tipo que cinge as humanidades e as ciências sociais”6. Essa disposição “coletiva” dos pesquisadores de pensar o objeto refletiria, como explicitado no prefácio ${ }^{7}$, “a própria filosofia e métodos mais comumente encontrados em nosso principal assunto, o New Popular Theatre, no qual um sistema de valores comuns servem para unificar a diversidade das correntes de pensamento e prática”.

No caso de Weiss e De Costa, é preciso atentar para o uso do termo "popular" nos títulos das obras, os quais força uma guinada numa direção, na qual o andamento das pesquisas sobre o "nuevo teatro” até agora parece não confirmar totalmente. A questão do “popular” detém muita ambigüidade e será retomada no devido tempo, ficando por hora em suspenso, indicada nesse momento apenas como uma problemática a ser posteriormente discutida.

Não há dúvida de que as obras dos três trazem muitas contribuições para o estudo do teatro latino-americano, mesmo diante das limitações de que também são vítimas como alguns críticos apontaram: David Lehmann vai afirmar que Versényi “sugere uma generalização baseada em grupos, autores e incidentes específicos escolhidos cuidadosamente”, e, nesse sentido, “o argumento é construído sob a pretensão de que a análise dos pontos específicos da articulação entre política, religião e teatro pode ser aplicada à América Latina como um todo”,

Nesse sentido, vale ressaltar um aspecto importante como o levantado pelo crítico acima: embora a grandiloqüência dos títulos recorra a um sintagma tal como "teatro latinoamericano”, em que o adjetivo composto “latino-americano” qualifica singularmente manifestações teatrais múltiplas, díspares, contraditórias e as vezes tão distintas entre si, o

\footnotetext{
${ }^{5} \mathrm{O}$ coletivo foi formado por seis membros do Executivo da Associação dos Trabalhadores e Investigadores do Nuevo Teatro (1985-1992). Os membros do coletivo são: Judith Weiss, Leslie Damasceno, Donald Frischmann, Claudia Kaiser-Lenoir, Marina Pianca e Beatriz J. Rizk.

${ }^{6}$ Citações diretas serão traduzidas (pelo próprio pesquisador) no corpo do trabalho, deixando-as na língua de origem, disponíveis nas notas de rodapé: “The colective nature of the research, the planning, and the writing make it, as far as we know, the first project of its kind to embrace the humanities and the social sciences”. In Weiss, J. Latin american Popular Theatre: the first five centuries, no prefácio, p. vii.

${ }^{7}$ Ibidem: "Moreover it has come to reflect both the philosophy and the methods most commonly found in our main subject, the New Popular Theatre, in wich a common value system serves to unify a diversity of currents of thought and practice”.

${ }^{8}$ (Book Reviews, 1995, p.397).
} 
conteúdo destas obras acaba recorrendo a experiências pontuais, limitadas no tempo e no espaço, de modo que ampliá-la para a totalidade do conjunto de países da América Latina, pode colocar em evidência a fragilidade de tais empreitadas pelo relativo falseamento e imprecisão de suas abordagens.

Ainda uma questão se faz digna de nota. Trata-se do lugar de enunciação dos pesquisadores. O coletivo de Weiss, Versényi e De Costa constituem o ponto de vista estrangeiro, dos países centrais, hegemônicos, dos “colonizadores culturais”, portanto, é "natural” reproduzirem em suas assertivas a ideologia inerente a esse locus, como a idéia determinista de "progressão" ou da "linha evolucionista da história"9.

Em contraposição a esse viés, pensadores “locais” utilizam a idéia de "rotas”, num "zigue-zaguear" de saltos e sobressaltos, curvas, atalhos e desvios, avanços e recuos intermitentes, estratégia mais pertinente, parece, à abordagem do caráter labiríntico das formas do fazer e produzir teatro na região. É o que se pressente na obra editada pelo autor colombiano Giorgio Antei (1989), Las Rutas del Teatro ${ }^{10}$, na qual, pode-se ler o seguinte trecho:

Las rutas de que habla el título de este libro aluden a los viajes efectuados por los hombres a través de la historia en busca del teatro; por tanto, aluden también a unas experiencias teatrales concretas, ocurridas en el tiempo y en el espacio, las cuales, vistas en contraluz, conforman un perfil o, aun mejor, un mapa. El teatro, en efecto, equivale a un mapa, a un portulano, a un espacio surcado, marcado, diseñado por viajes y rutas. Por tanto, no nos detengamos a preguntar qué es el teatro. Preguntémonos, en cambio, qué rutas trazaron aquéllos que fueron a su encuentro.

A analogia com um mapa, leva-o a afirmar a lógica "geográfica” do livro: “...como los primeros mapas americanos, traza, de las nuevas tierras, un perfil abierto e inacabado, interrumpido por una fórmula frecuente entre los cosmógrafos del siglo XV: terra

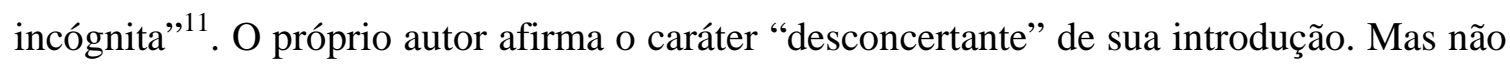
só a introdução, o desconcerto caracteriza a totalidade do livro, como deixa entrever uma

\footnotetext{
${ }^{9}$ Cf.: Weiss, J., op. cit, p. 4: “...we do acknowledge its importance in the evolution of a historical line that leads directly to the Nuevo Teatro Popular”. E o sub-título em seguida "Historical Evolution of Latin American Popular Theatre”.

${ }^{10}$ Bogotá: Centro Editorial, Universidad Nacional de Colômbia, 1989, p.9.

${ }^{11}$ Ibidem.
} 
resenha sobre a obra escrita por um conterrâneo seu, Fernando Gonzalez Cajiao (2006). Em seu texto, Cajiao não disfarça seu desconforto diante da obra, critica a falta de unidade e a sensação de que as coisas foram deixadas "un poco a medio camino". Depois de elogiar alguns artigos, centra sua crítica, referindo-se ao livro como "no digerido, algo desordenado, precipitado, sin un claro y único objetivo; excesivamente diverso, sin una verdadera unidad, no sólo temática, sino también formal”. E conclui sobre esta forma de publicar, sem nenhuma unidade de estilo e de conteúdo, que "tiende a volverse una infortunada costumbre entre los ensayistas de teatro colombiano" ${ }^{\text {12. }}$.

Na verdade, com mérito ou não, Antei conseguiu plasmar na concretude da obra, em sua falta de forma e unidade, o próprio caráter aberto, inacabado e incógnito do teatro manifesto e produzido na América Latina. Afinal, "não há diferença entre aquilo de que um livro fala e a maneira como é feito"13. E isso não quer dizer tampouco que Cajiao não tenha razão em suas formulações críticas. Mas é preciso se perguntar em razão de que ponto de vista a obra é ou não dessa ou daquela forma, com ou sem unidade de forma?

É importante chamar atenção para isso, tendo em vista o fato de que a maior parte dos historiadores latino-americanos que se debruçaram sobre a história do teatro latinoamericano ou história do teatro "nacional”, também são orientados dentro do marco do pensamento lógico e racional ocidental, portanto, dentro da tal "linha evolucionista da história”, cujo ponto máximo de desenvolvimento teatral possível seria o alcance da produção de formas estéticas niveladas com as produzidas nos países de "Primeiro Mundo”.

Dentro dessa linha, é possível evocar um conjunto de obras de autores locais, cuja unidade de estilo e conteúdo são incontestáveis, tais como: História del teatro uruguayo 1808-1968 de Walter Rela (1969); De Goldoni a Discépolo. Teatro italiano y teatro argentino 1790-1990, e Pirandello y el teatro argentino, ambos de Osvaldo Pellettiere (1997, 1994); Teatro y Teatristas: estúdios sobre teatro argentino e iberoamericano de Osvaldo Pellettiere (editor); El teatro de calle: técnica y manejo del espacio de Fabrizio Cruciani e Clélia Falleti (1992); História Concisa do Teatro Brasileiro de Décio de

\footnotetext{
${ }^{12}$ Artigo capturado na Internet: Boletín Cultural y Bibliográfico, Número 22. Volumen XXVII, 1990. No site: http://www.lablaa.org/blaavirtual/publicacionesbanrep/boletin/boleti5/bol22/veraci.htm. Acesso: 19/04/2006. ${ }^{13}$ In Deleuze, Gilles; Guattaria, Félix. Mil Platôs: capitalismo e esquizofrenia. Trad. Aurélio Guerra e Célia Pinto Costa. Vol. 1. Rio de Janeiro: Ed. 34, 1995. p.12.
} 
Almeida Prado (1999); El alma del teatro independiente de E. Agilda (1960); El teatro independiente, José Marial (1995); El teatro en el Rio de la Plata., Luiz Ordaz (1957); só para citar alguns deles. Obras, cujas contribuições são incalculáveis ao processo de "autoconhecimento” da América Latina.

Nesse ponto, pode ser pertinente lembrar as palavras comoventes de Antônio Cândido ao se referir à literatura produzida em países situados na "periferia do capitalismo", em virtude do fato de o mesmo pronunciamento ser válido para a produção teatral, menos pelo compartilhamento da natureza literária que a dramaturgia evoca, quanto pelo fato de ser a arte que, determinada pela contingência de diversos fatores, se é capaz de fazer:

Comparada às grandes, a nossa literatura é pobre e fraca. Mas é ela, não outra, que nos exprime. Se não for amada, não revelará a sua mensagem; e se não a amarmos, ninguém o fará por nós. Se não lermos as obras que a compõe, ninguém as tomará do esquecimento, descaso ou incompreensão. Ninguém, além de nós, poderá dar vida a essas tentativas muitas vezes débeis, outras vezes fortes, sempre tocantes, em que os homens do passado, no fundo de uma terra inculta, em meio a uma aclimação penosa da cultura européia, procurava, estilizar para nós, seus descendentes, os sentimentos que experimentavam, as observações que faziam, - dos quais se formaram os nossos ${ }^{14}$.

Com os problemas ou limitações de toda ordem, esse é o teatro que se consegue produzir; essas são as tentativas de registrar e explicar as experiências teatrais da região. Do mesmo modo que as tentativas literárias do século XIX, a despeito de todo empenho em se espelhar na Europa, voltava-se também aos problemas locais e se alçava como porta-voz da busca de uma identidade nacional, em construção, de nações também em construção. Na segunda metade do século XX, o que se presenciará, será um teatro que tomou para si a tarefa, não só de construir uma identidade, mas também a de problematizá-la, aprofundá-la, discuti-la e levá-la as últimas conseqüências, de modo a enfrentar a problemática sempre em voga, jamais resolvida, da busca de uma identidade, debilmente forjada, expondo suas contradições e ambigüidades.

Com relação à produção acadêmica local sobre o teatro latino-americano, pode-se afirmar que remonta aos anos 50-60 o afã de tal reflexão, e se desenvolveu como parte de

\footnotetext{
${ }^{14}$ Mello e Souza, Antônio Cândido. Formação da Literatura Brasileira. $3^{a}$ ed., vol.1. São Paulo, Martins, 1969. Prefácio da $1^{\mathrm{a}}$ edição, p.10.
} 
um movimento maior dos intelectuais ${ }^{15}$ de pensar a problemática latino-americana com respeito à sua formação histórica, a sua configuração socio-política e econômica, sua identidade, cultura e o seu projeto de futuro.

No pós-guerra, sob influência direta das práticas teatrais européias, tem início entre os grupos teatrais recém-formados, o costume de produzir sua própria teoria e reflexão crítica concomitantemente à sua prática artística, a partir de publicações em “folders”, nos programas de seus espetáculos, em revistas, ou outro tipo de material de divulgação, como é o caso, por exemplo, dos primeiros textos de Enrique Buenaventura, quando da estréia de sua primeira montagem, A la diestra de Dios Padre, em 1958. Ali, tivera lugar o lançamento ainda em germe de alguns princípios que orientariam o movimento ao longo de seu desenvolvimento, como "a idéia de um teatro nacional”"16.

A tendência do último quartel do século vinte foi a da abordagem do teatro à luz dos conceitos da Semiótica ou Semiologia. Os dois termos são usados quase como sinônimos, a distinção terminológica tem haver com a forma da concepção da idéia de signo. Portanto, a diferença não é uma simples polêmica de palavras, nem um resultado de batalha terminológica franco-americana entre semiotics de Peirce e a sémiologie de Saussure”. Mas por representar dois modelos de signos distintos: para este, o signo se limita à aliança de um significado e de um significante; para aquele, é necessário acrescentar a estes termos, a noção de referente - isto é, da realidade denotada no signo ${ }^{17}$. A semiologia, ciência dos signos, “é um método de análise do texto e/ou da representação, atento a sua organização formal, à dinâmica e à instauração do processo de significação por intermédio dos praticantes do teatro e do público" ${ }^{18}$.

\footnotetext{
${ }^{15}$ É notável, nesse sentido, o processo de aclimatação e de consolidação da Sociologia como ciência privilegiada no processo de interpretação da realidade latino-americana. Vale conferir o artigo de Tavares dos Santos, José Vicente and Baumgarten, Maíra. Sociology's contribution in Latin America to sociological imagination: analysis, critique, and social commitment. Fonte:

$<$ http:/www.scielo.br/scielo.php?script=sci_arttext\&pid=S1517-45222005000200009\&lng=en\&nrm=iso Nesse artigo, os autores identificam seis períodos na Sociologia na América Latina e no Caribe: I) a herança intelectual da Sociologia (Século XIX até início do Século XX); II) a Sociologia da cátedra (1890-1950); III) o período da "Sociologia Científica" e a configuração da "Sociologia Crítica" (1950-1973); IV) a crise institucional, a consolidação da "Sociologia Crítica" e a diversificação da Sociologia (1973-1983); V) a Sociologia do autoritarismo, da democracia e da exclusão (1983-2000); VI) a consolidação institucional e a mundialização da Sociologia da América Latina (desde o ano de 2000).

${ }^{16}$ Gonzalo Arcila, 1983: p.29.

${ }^{17}$ PAVIS, P. Dicionário de Teatro, 2005, p.350.

${ }^{18}$ Idem, ibidem.
} 
Ainda que se tenha apontado a resistência do teatro às tentativas de leitura semiológica, em virtude tanto de sua "complexidade específica”19 baseada na múltipla combinação de signos distintos, quanto da impossibilidade de detecção no teatro de uma unidade mínima de significação ou do signo mínimo, o fato é que se tem visto o crescimento paulatino deste tipo de abordagem, explicitado nas publicações mais recentes, como por exemplo:

Semiótica y Teatro Latinoamericano, do editor Fernando de Toro (1990); La puesta em escena en latinoamerica: teoria y practica teatral de Osvaldo Pellettiere e Eduardo Rovner (editores); Trânsitos e Deslocamentos Teatrais: da Itália à América Latina de Sara Rojo (2005); Semiótica, Ideología y Teatro Hispanoamericano Contemporâneo, de Raúl H. Castagnino (1987).

Para o foco determinante dessa pesquisa, um conjunto de obras foram selecionadas como sustentação das referências e construçôes históricas. São elas: Materiales para una historia del teatro em Colômbia, de Maida Watson Espener e Carlos José Reyes (1986*conferir); Violência y Literatura em Colômbia do editor Johnathan Tittler (1989); Investigación y Práxis Teatral en Colômbia de Fernando Duque Mesa, Fernando Peñuela Ortiz e Jorge Prada Prada (1994); Las rutas del teatro de Giogio Antei (1989); El nuevo teatro colombiano y la colonización cultural de Maria Mercedes Velasco (1997); e Historia del teatro en Colômbia de Fernando Gonzalez Cajiao (1986); Notas sobre Teatro de Miguel Rubio Zapata (2001); Violent Acts: a study of contemporary Latin American Theatre de Severino João Albuquerque (1988).

Com relação ao ponto da discussão, na qual se encontra a reflexão e a revisão históricas sobre o movimento do "el nuevo teatro", na Colômbia, basta a título de introdução, evocar a polêmica com referência a três artigos, produzidos no início do século XXI: 1. “Teatro em Colômbia”, texto que é construído a partir das respostas de quatro personalidades à seguinte pergunta: “ ¿Qué papel lê asigna al método de la creación colectiva en la historia del teatro colombiano””, numa clara referência `as experiências de

\footnotetext{
${ }^{19}$ Coelho Netto, J. Teixeira. Preliminar, p. 11. In: Semioliga do Teatro. (1988)
} 
Buenaventura e Garcia ${ }^{20}$. 2. "El legado de Enrique Buenaventura”, artigo de María Mercedes Jaramillo e Betty Osório, no qual saem em defesa contra o ataque à "fortuna" cultural legada pelo teatrólogo colombiano; e, 3. o artigo de Claudia Montilla V., "Del teatro experimental al nuevo teatro, 1959-1975”, no qual a autora ataca à vertente teatral defendida por Enrique Buenaventura e seus aliados, identificando nesta vertente o início do processo de sufocamento do nascente teatro experimental, o qual teria sido o verdadeiro teatro em Colômbia ${ }^{21}$. Esse debate constitui, em última instância, uma opção com relação à poética teatral que se quer para América Latina. A experiência do Nuevo Teatro, a vertente considerada “vencedora” no enfrentamento que teve início nos idos anos 50, foi sem dúvida quem mais contribuiu para a compreensão contemporânea do que seja essa tal poética teatral latino-americana, como pode ser constatada na abordagem de Franklin Rodríguez, para quem Teatro Latinoamericano significaria

no solamente al teatro multinacional, multiétnico, multi-lingüístico que se produce en el área continental, o al teatro de procedencia lingüística latina, sino a todo aquel teatro hecho por Latinoamérica y se proponen figurarla y transformarla. En el concepto de Teatro Latinoamericano incluimos al Teatro Caribeño de lengua inglesa, holandesa, francesa, española etc., así como el teatro contestario de las minorías latinas en EE.UU, como el Teatro Chileno y el movimiento Off-Off-Broadway. Habría que añadir también en este contexto al Teatro del Exilio (político o voluntario), que se realiza fuera del continente sín perder la perspectiva latinoamericana.

Los criterios para determinar la "Latinoamericaneidad" del Teatro de Nuestra América entonces, no solamente los determinan la procedencia espacial o lingüística del teatro, sino sobre todo la Identificación concreta del discurso y la imagen teatral com la historia, la cultura y la liberación latino-americana ${ }^{22}$.

Ao esboçar estas quatro últimas referências, fica evidente a colocação da questão teórico-empírica que se defronta: a saber, deslindar nesse debate, a localização históricocultural do legado real dos grupos teatrais TEC e La Candelaria, e de seus representantes

\footnotetext{
${ }^{20}$ A personalidades que respondem à questão são: María Mercedes Jaramillo do Fitchburg State College; Betty Osório da Universidade dos Andes; Beatriz Rizk, pesquisadora, e Eduardo Gómez da Universidade dos Andes.

${ }^{21}$ Fonte: Revista de Estúdios Sociales, $\mathrm{n}^{\circ} 17$, febrero de 2004. Capturado da Internet.

${ }^{22}$ Apuntes para uma poética del teatro latinoamericano. In: (DE TORO, 1990). Grifo nosso.
} 
Buenaventura e Garcia, com relação à suposta construção de uma "latinoamericanidad" teatral, de uma poética própria específica do teatro latino-americano.

\section{Referências conceituais}

\section{O ponto de vista da Sociologia}

A produção simbólica e artística é uma evidência que remonta a comunidade humana desde seus primórdios. Para usar, como Garcia Canclini, um exemplo latinoamericano: eis aí em “qualquer comunidade indígena pré-colombiana” exemplos de práticas artísticas que “ajudar-nos-á a recordar de que maneira se relacionavam os temas e as formas da arte, a escolha deste animal ou daquela cor com as diferenças de hierarquia política e poder religioso”23. Apesar dessa evidência e depois de toda as revoluções científicas, do surgimento de novas áreas do conhecimento no curso dos séculos XIX e XX, a Sociologia da Arte, segundo diagnóstico de Garcia Canclini, "não existe ainda como disciplina científica, com uma teoria devidamente fundamentada e um número suficiente de pesquisas particulares que a avalizem, ${ }^{24}$.

Do mesmo jeito que “o interesse sociológico nas questões da "realidade” e do “conhecimento" justifica-se assim inicialmente pelo fato de sua relatividade social”, o interesse sociológico nas questões do fato simbólico, isto é, da produção artística, pode e deve considerar este relativismo. A sociologia do conhecimento constata que,

o que é "real" para um monge tibetano pode não ser "real" para um homem de negócios americano. O "conhecimento" do criminoso é diferente do "conhecimento" do criminalista. Segue-se que aglomerações específicas da "realidade" e do "conhecimento" referem-se a contextos sociais específicos e que estas relações terão de ser incluídas numa correta análise sociológica desses contextos ${ }^{25}$.

\footnotetext{
${ }^{23}$ GARCIA CANCLINI, Nestor. A produção simbólica: teoria e metodologia em sociologia da arte. Rio de Janeiro, Civilização Brasileira, 1979, p.11.

${ }^{24}$ GARCIA CANCLINI, 1979, p.12.

${ }^{25}$ BERGER, Peter L. \& LUCKMANN, Thomas. A Construção Social da Realidade. 18 ed. Petrópolis, Vozes, 1999, pp.13-14.
} 
Este problema do relativismo se reflete diretamente na arte teatral. Uma das grandes polêmicas entre os especialistas é definir se as práticas ritualísticas dos povos précolombianos eram ou não "teatro", este identificado de forma geral com aquele teatro europeu e burguês de meados dos séculos XIX; quando, na verdade, este teatro era apenas uma das formas de manifestação do Teatro; como o conhecimento de outras culturas nãoocidentais permitiu saber.

Se a sociologia do conhecimento trata "não somente da multiplicidade empírica do ‘conhecimento’ nas sociedades humanas, mas também dos processos pelos quais qualquer corpo de 'conhecimento' chega a ser socialmente estabelecido como 'realidade’”, a sociologia da arte e/ou as sociologias das várias modalidades artísticas terão de estabelecer seu programa de trabalho, como procedimento de superação do entendimento de que ela se restrinja a ser apenas um “campo de problemas”26.

Embora Pierre Francastel seja criticado por Garcia Canclini, que vê em seu estudo não “sociologia da arte”, mas um trabalho histórico, a verdade é que Francastel aponta diversas questões pertinentes ao desenvolvimento da disciplina, ainda mais considerando o momento contemporâneo, cujo nível de complexidade têm exigido práticas inter- ou transdisciplinares. Assim, reter-se-á aqui algumas definições propostas por Pierre Francastel, como a de arte, por exemplo. Ele diz que “o caráter da obra de arte é de ser tanto em relação ao pensamento do artista quanto em relação ao do espectador”. Essa compreensão parece similar àquela refletida pelos fundadores do Nuevo Teatral quando entendem a imagem teatral como sendo aquela terceira formada a partir da percepção do espectador da imagem concreta criada no palco.

A imagem, para Pierre Francastel, é constituída "por um agrupamento de elementos reorganizados a partir do real e ligados simbolicamente”. Trata-se de uma "forma” que “integra no nível da representação mental elementos isolados, incorporando-os numa estrutura diferente, mas tão racional, por exemplo, quanto as línguas ou os sistemas de sinais matemáticos”27. Para ele,

\footnotetext{
${ }^{26}$ GARCIA CANCLINI, 1979, p.12.

${ }^{27}$ FRANCASTEL, Pierre. "Problemas da Sociologia da Arte”. In: VELHO, Gilberto. Org. Sociologia da Arte II. Rio de Janeiro, Zahar,.
} 
quem quer que seja sensível à linguagem visual sabe bem que, ao contrário, a leitura de uma obra de arte seja qual for - quadro, estátua, monumento ou filme - requer tempo e esforço e que, jamais, se trata de descobrir de uma só vez a totalidade dos aspectos de uma obra um pouco refinada, onde o autor colocou os tesouros acumulados de uma experiência somada num sistema que não reproduz nunca o movimento de sua observação do real ${ }^{28}$.

Ainda sobre a questão da imagem, Pierre Francastel afirma:

Toda imagem figurativa - ou mesmo todo objeto figurativo - é o final de uma experiência e, ao mesmo tempo, o ponto de partida de uma nova experiência que a reintroduz no espírito de seu autor como um ponto fixo em torno do qual se cristalizam", em seguida, os processos combinados de pensamento e de ação ${ }^{29}$.

“Toda obra de arte torna-se também, uma vez cristalizada, o ponto de partida de uma reflexão para quem sabe olhar”. Apreciar um quadro ou uma peça de teatro é, pois, estabelecer um diálogo tanto com a materialidade visível da obra quanto "com uma experiência humana”. Como "produto de uma sabedoria, a obra de arte é fixa, mas sua interpretação é móvel”. Portanto, “o caráter da obra de arte é de ser tanto em relação ao pensamento do artista quanto em relação ao do espectador”.

É preciso estabelecer neste ponto uma distinção fundamental entre a imagem e o objeto. Na concepção de Pierre Francastel, “pertence ao domínio do objeto tudo aquilo que é suscetível de identificação fragmentária, seja com um elemento reconhecível do real, seja com um elemento figurativo anteriormente utilizado”; por outro lado,

pertence ao domínio da forma tudo aquilo que constitui uma nova ordem de agrupamento capaz de modificar o valor relativo dos elementos materiais utilizados e de sugerir através de uma nova apreensão global, aprofundada necessariamente por uma decifração do esquema funcional de integração das partes, dos modos de conduta ou de compreensão ${ }^{30}$.

O objeto figurativo é um fato de civilização. Nesse sentido, "nunca se trata (...) do diálogo isolado de seu meio". Para Francastel, “só aprendemos o pensamento do outro num

\footnotetext{
${ }^{28}$ FRANCASTEL, Pierre, 1967, 10-27.

${ }^{29}$ FRANCASTEL, Pierre, 1967, pp.10-29.

${ }^{30}$ FRANCASTEL, Pierre, 1967, pp.10-29.
} 
contexto e ele suscita em nós reações não somente sentimentais como intelectuais. É a razão profunda pela qual o objeto figurativo é necessariamente um objeto de civilização”31 .

Pierre Francastel conclui este tópico sem se posicionar favoravelmente à tese, que identifica arte com valores comuns da sociedade e do pensamento, na verdade ele não está preocupado com a problematização da especificidade da arte nem em seu caráter espiritual. Ele não permite reduzir esta arte nem ao personalismo de Croce nem ao simbolismo de outros tantos como Novalis, mas a arte está primordialmente vinculada à experiência. Sendo assim, é principalmente "um modo de compreensão e um modo de ação que informa a totalidade da experiência”; (...) “é uma atividade material e simbólica que não se limita à elaboração de objetos não-usuais, mas que se associa às modalidades as mais diversas de ação"32. Com relação à função da arte, ela "pode ser um elemento de coesão social ou de dissociação”. “A forma plástica não é reflexo das aparências, nasce no nível dos problemas; não se trata de ordenar elementos esparsos com maior ou menor engenhosidade, nem de exaurir em um repertório de existentes; a forma é um dinamismo. Não está no objeto, mas no impulso que lhe deu origem. O sinal, dizia Matisse, se determina no momento em que ele se descobre em função da obra em questão”.

A partir dessas colocações esquematicamente evocadas aqui, Pierre Francastel apresenta seu programa para uma sociologia da arte. Ele assevera antes que, "a experiência de cada um prova facilmente que não há maneira alguma de determinar uma ação fora de uma escolha”. Nesse sentido, o "papel próprio da arte é fornecer às sociedades um meio de fabricar objetos de civilização materializando uma ordem ao mesmo tempo representativa e operatória de uma decomposição, ousadamente elaborada, dos dados da vista ou do ouvido”. E enfim, “não pode haver Sociologia da Arte - nem Arte simplesmente - senão a partir da intencionalidade".

Do ponto de vista da Sociologia da Arte, Pierre Francastel apresenta a seguinte subdivisão dos campos de estudo:

1. “Sociologia dos grupos e tipologia das civilizações: sua tarefa (...) é (...) analisar as relações da arte com os grupos criadores e utilizadores das obras de arte. (...) A arte é

\footnotetext{
${ }^{31}$ FRANCASTEL, Pierre, 1967, p.29.

${ }^{32}$ FRANCASTEL, Pierre, 1967, 10-27.
} 
um lugar de reencontro de indivíduos pertencentes, por outro lado, a classes muito variadas; é também uma ligação entre indivíduos separados no tempo e no espaço”.

2. "Sociologia das obras: à Sociologia dos grupos criadores e utilizadores da arte, devemos juntar a Sociologia das obras ou, mais precisamente, dos objetos artísticos de civilização”.

3. "Sociologia dos objetos figurativos e dos meios de expressão: uma terceira categoria de pesquisas pode resultar da tomada em consideração não mais das obras em sua complexidade, mas de seus elementos constitutivos, isto é, dos instrumentos figurativos e de seus meios de expressão”.

4. "Sociologia dos modos de apresentação: Nessa série de estudos estão aqueles que tomam por objeto: os ritos, as liturgias, as festas; o teatro e a dança; a vestimenta; os modos de apresentação particulares a certas civilizações: museus, estampas,...

5. "Sociologia artística comparada: sinais e símbolos: aplica-se à análise de todos os tipos de sinais e suas relações.

6. "Sociologia da arte na sociedade industrial: "a arte é uma atividade intelecutal que se exerce e se manifesta na matéria. ${ }^{33}$

A partir da apropriação de certos conceitos de Pierre Francastel, como o da imagem, mas aplicada antes ao teatro, o presente trabalho situa-se, dentro do programa apresentado pelo sociólogo, na linha de estudo referente à Sociologia dos modos de apresentação ${ }^{34}$.

\section{Vanguarda como categoria teórica}

A teoria da vanguarda de Peter Bürger fornece proposta mais recente de análise, posicionada num ponto mais recente da linha da crítica cultural, baseada tanto na releitura de conceitos de Marx quanto numa revisão conceitual da tradição crítica da escola de Frankfurt. Por meio destas duas operações, Bürger reconstrói seu próprio arsenal conceitual e sua metodologia numa estrutura complexa para proceder à “compreensão objetiva” da função social da arte contemporânea. Apropria-se de categorias teóricas de vários autores alinhados com a crítica marxista, aplicando-os ao âmbito artístico.

\footnotetext{
${ }^{33}$ FRANCASTEL, Pierre, 1967, p.41.

${ }^{34}$ FRANCASTEL, Pierre, 1967, p.41.
} 
Sua primeira tese refere-se à historicidade das categorias estéticas: "é valido historicizar a teoria estética”, por que “a visão da história como pré-história do presente, característica das classes ascendentes, é unilateral (sem prejuízo do seu progressismo) [...], porquanto registra apenas uma face do progresso histórico e reserva a outra ao falso objetivismo historicista”(p.44). Historicizar a teoria significa, pois, investigar a relação entre o desenvolvimento dos objectos e as categorias de uma ciência. Assim entendido, o caráter histórico de uma teoria não consiste em expressar o espírito de uma época (o seu aspecto histórico), nem em incorporar parte de teorias pretéritas (história como pré-história do presente), mas em relacionar o desenvolvimento dos objetos com o das categorias. Historicizar uma teoria estética significa captar essa relação. (...) Ser um meio de reflexão que capta através de uma linguagem a historicidade do seu próprio discurso.

Para ilustrar como isso se dá efetivamente Peter Bürger recorre ao exemplo da “validade [de uma categoria] para qualquer época” e o conhecimento dessa validade geral, isto é, o conhecimento das "relações históricas das quais a validade geral é produto, e cuja aplicação, por sua vez, seria válida somente a elas. Marx demonstra seu princípio por sua vez evocando o sistema monetário inglês. Para acompanhar o raciocínio de Marx, e depois o do próprio Bürger, faz-se necessário a longa citação deste trecho:

A teoria dos fisiocratas referiu-se ao trabalho como fonte de riqueza, embora não ao trabalho em geral, mas apenas à sua modalidade agrícola. A economia clássica inglesa (Adam Smith) não mencionou um gênero determinado de trabalho, mas o trabalho em geral como fonte de riqueza. Marx não vê nesta evolução um simples desenvolvimento da teoria econômica; a possibilidade do progresso do conhecimento parece-lhe antes motivada pelo desenvolvimento do objeto sobre o qual incide o conhecimento. Quando os fisiocratas elaboraram a sua teoria, durante a segunda metade do século XVIII francês, a agricultura era, de facto, o sector econômico dominante. Só uma Inglaterra economicamente muito desenvolvida, onde a Revolução Industrial já se havia estabelecido, com o conseqüente enfraquecimento do predomínio da agricultura sobre os restantes setores produtivos históricos, permitiu a Smith descobrir que a riqueza é produzida pelo trabalho em geral e não por uma determinada espécie de trabalho ${ }^{35}$.

\footnotetext{
${ }^{35}$ Resumo da reflexão de Marx sobre a questão da validade de uma categoria histórica. In BÜRGER, Peter. A teoria da vanguarda. Lisboa: Vega, 1993, p. 45.
} 
Citando Marx diretamente, Bürger fecha o resumo sobre a reflexão do primeiro assim: “a falta de interesse por um determinado tipo de trabalho pressupõe uma totalidade desenvolvida de tipos de trabalho sobre os quais já nenhum em particular é dominante ${ }^{36}$.

Agora, Peter Bürger aplica essa conclusão marxista ao âmbito de sua própria atuação como pesquisador: o âmbito da crítica e teoria da arte. Deste modo, ocorre a apropriação de conceitos e reflexões de um conjunto de autores, fundamentando a sua própria teoria. Tem-se, assim, a exposição da primeira tese de Bürger:

....a tese que defendo sustenta que a relação posta em evidência por Marx entre o conhecimento da validade geral de uma categoria e o efetivo desenvolvimento histórico dos objetos a que essa categoria se aplica, também é válida para as objetivações artísticas. Ainda aqui a diferenciação dos âmbitos dos objetos é que torna possível o conhecimento adequado dos mesmos. Contudo, a plena diferenciação dos fenômenos artísticos apenas se alcança na sociedade burguesa com o esteticismo, ao qual respondem os movimentos históricos de vanguarda ${ }^{37}$.

A conseqüência dessa apropriação é a definição de “meio artístico” como categoria geral para a descrição das obras de artes, cuja aplicação a processos particulares só seria possível por sua vez a partir dos movimentos de vanguarda. Bürger afirma, "enquanto um estilo domina, a categoria de meio artístico é opaca porque na realidade só se dá como algo de especial”. Vale a pena seguir o desdobramento dessa idéia noutra citação:

Um traço característico dos movimentos históricos de vanguarda consiste, precisamente, em não terem elaborado nenhum estilo; não há um estilo dadaísta, nem um estilo surrealista. Na verdade, estes movimentos acabaram com a possibilidade de um estilo da época ao converterem em princípio a disponibilidade dos meios artísticos das épocas passadas. Só a disponibilidade universal generaliza a categoria de meio artístico.

A implicação disso é clara. Só o desenvolvimento completo do objeto permite reconhecer a validade geral da categoria. Isso poderia levar a pensar que se trata de deslocamento do "ato de conhecimento para a realidade", e conseqüente "negação do sujeito produtor de conhecimento”. Mas Bürger alerta para o equívoco de uma tal

\footnotetext{
${ }^{36}$ Apud Bürger, Peter. Op. cit., p.45.

${ }^{37}$ Bürger, Peter. Op. cit., p.45-46.
} 
interpretação. Trata-se, antes, de "reconhecer que as possibilidades de conhecimento estão limitadas pelo desenvolvimento real (histórico) dos objetos” (p.47).

Na seqüência de sua elaboração teórica, Bürger evoca o que ele chama de "teorema” de Adorno, segundo o qual, “a chave de todo o conteúdo da arte reside na sua técnica”; e o esclarece a partir da própria conclusão a que sua linha de raciocínio, apoiada em Marx, está levando. Assim, tem-se o seguinte: a condição histórica da possibilidade de perceber categorias da obra de arte na sua validade geral é o desenvolvimento da arte na sociedade burguesa, cuja tendência foi sempre a de beneficiar a forma em prol do conteúdo. Este predomínio da forma é visto do ponto de vista da produção estética como disposição sobre o meio artístico. Isto é, “os meios artísticos transformam-se no que são (ou seja, na forma) na medida em que a categoria de conteúdo é relegada para plano secundário”(p.48). Assim, junto com Bürger, torna-se possível compreender a tese de Adorno referida acima.

Mas, ao tornar compreensível a tese adorniana, imediatamente é iluminado também outro aspecto: a sua limitação conceitual. Bürger mostra de que modo se dá essa limitação, indicando a sua "pretensão de validade geral". "Se temos razões para acreditar que o teorema de Adorno só pode formular-se com base no desenvolvimento verificado na arte a partir de Baudelaire, é discutível a sua pretensão de validade para épocas anteriores”. E recupera a reflexão metodológica de Marx, citada anteriormente para fechar essa questão da validade geral de um conceito: “...as categorias possuem 'validade plena’ só para e no seio das relações cujo produto constituem”(p.49). Seu esforço foi o de "colocar o problema da possibilidade de um conhecimento do passado que não creia na ilusão histórica de uma compreensão desse passado que dispense o recurso a hipóteses, nem simplesmente o submeta a categorias que são o produto de uma época posterior”(p.49).

Em sua segunda tese, defende "a vanguarda como autocrítica da arte na sociedade burguesa”. Evoca de novo "outra reflexão [de Marx] de grande alcance metodológico" concernente à possibilidade de "conhecer formações parciais de sociedades do passado" (p.49). Não dá para levar em consideração "posição historicista, que julga poder compreender formações sociais do passado sem as relacionar com o presente da investigação”, posição que leva lamentavelmente a uma construção progressiva da história como pré-história do presente. 
O chamado desenvolvimento histórico baseia-se geralmente em que a última forma considera as precedentes como passos em direção a ela própria, e por isso só é capaz de uma autocrítica escassa e sob condições muito determinadas - não falamos, é bem de ver, dos períodos históricos que se sabem decadentes - , adotando sempre um ponto de vista unilateral $^{38}$.

Ou seja, "um todo contraditório não se concebe dialeticamente, captando apenas um aspecto da contradição”. Dessa forma, a construção do passado como pré-história do presente, só poderia ser uma construção unilateal, que capta apenas um aspecto do processo contraditório do desenvolvimento histórico. Para superar este problema, Marx evoca o papel da autocrítica. Bürger se apropria da solução dada por Marx a este problema, a qual ao invés de introduzir o futuro, introduz "o conceito de autocrítica do presente”. Assim, considera-se a "autocrítica do presente" como estratégia para conhecer o passado em sua totalidade de realidade contraditória. Para compreensão desse conceito, Marx, na leitura de Bürger, distingue a autocrítica de outro tipo de crítica, a saber, a crítica imanente ao sistema, cuja particularidade consistiria em funcionar no seio de uma instituição (p.50-51). O exemplo clássico de Marx é a religião. Na instituição religiosa, a crítica imanente é a crítica a determinadas concepções religiosas em nome de outras. "Por contraste, a autocrítica supõe uma distância das concepções religiosas que mutuamente se defrontam. Esta distância, porém, é fruto de uma crítica radical: a crítica à própria instituição religião”(p.51). Mais uma vez, Bürger se apropria deste conceito e o traslada ao âmbito artístico.

Exemplos da crítica imanente ao sistema seriam, porventura, a crítica dos teóricos do classismo francês ao drama barroco, ou a de Lessing às imitações alemãs da tragédia clássica francesa. Esta crítica move-se no interior da instituição teatro, onde existem várias concepções da tragédia opostas entre si, baseadas em diferentes posições sociais. Muito diferente é a crítica que abrange a instituição arte na sua totalidade: a autocrítica da arte ${ }^{39}$.

A conseqüência desse raciocínio é a tese de Bürger, segundo a qual, “....só quando a arte alcança o estádio da autocrítica é possível a ‘compreensão objetiva’ a épocas anteriores no desenvolvimento artístico". Outra implicação envolve a consideração desta

\footnotetext{
${ }^{38}$ Marx, K. Grundrisse, p.26. Apud BÜRGER, Peter. Op. cit., p.50.

${ }^{39}$ BÜRGER, Peter. Op. cit., p.51.
} 
“compreensão objetiva”. Para Bürger, a expressão “não significa uma compreensão independente da situação atual do sujeito que se propõe a conhecer, mas tão somente um estudo do processo completo, na medida em que este alcançou uma conclusão, ainda que provisória”(p.51).

A segunda tese de Bürger afirma assim que o subsistema artístico atinge, com os movimentos de vanguarda européia, o estádio da autocrítica, em que o dadaísmo, mais radical, já não critica as tendências artísticas precedentes, mas a instituição arte. Com o conceito de instituição arte, Bürger refere-se "tanto ao aparelho de produção e distribuição da arte quanto às idéias dominantes em arte numa época dada e que determinam essencialmente a recepção das obras”(p.52). O evolver do raciocínio de Bürger é tão preciso e complexo, que vale a pena citá-lo longa e integralmente:

A vanguarda dirige-se contra ambos os momentos: contra o aparelho de submissão a que está submetida a obra de arte e contra o status da arte na sociedade burguesa descrito pelo conceito de autonomia. Só depois da arte, com o esteticismo, se haver desligado por completo de qualquer relação com a vida prática, pôde espraiar-se o estético em toda a sua "pureza", embora assim tornasse manifesta a outra face da autonomia, que é a sua carência de função social. A autocrítica do subsistema social artístico permite a 'compreensão objetiva” das fases de desenvolvimento precedentes.

Do que foi exposto sobre parte do raciocínio da teoria da vanguarda de Peter Bürger, retome-se as duas categorias construídas, a saber, a "historicidade das categorias” e a "autocrítica" da arte na sociedade burguesa. Como seria analisar o movimento do "el nuevo teatro latino-americano" a partir destas premissas?

Cabe arrolar uma primeira hipótese, a de que, o movimento do "el nuevo teatro"(1965-1975) poderia se configurar como um fato social, que atingiu seu desenvolvimento completo, o que o torna passível de ser analisado e compreendido. É um fenômeno artístico situado no passado com relação ao ponto de vista do sujeito do conhecimento; e no futuro do pretérito com relação às vanguardas européias (1905-1930), o que gera novos problemas. Manifestado no seio de países periféricos e dependentes, o nível de complexidade do movimento artístico adquire dimensões impensáveis nos países centrais. 
A reverberação das vanguardas européias atingiu na época a periferia latinoamericana, mas restrita em suas modalidades literárias e visuais ${ }^{40}$. O teatro praticamente inexistia em quase toda a totalidade dos países da região, afora manifestações pontuais, atreladas à mentalidade do século XIX. Em contraste, o “modernismo” na literatura e nas artes plásticas aspirou vigor novo, sendo profundamente influenciado pelo que acontecia na Europa, acompanhando quase simultaneamente os manifestos artísticos, as informações e os debates e, ao mesmo tempo, voltando-se para as questões locais, como se se descobrissem pela primeira vez.

Esse descompasso temporal traz conseqüências importantes para a arte latinoamericana, em especial o teatro, em virtude do seu nível de acúmulo de informações, heranças e referências. O movimento do "Nuevo Teatro" ocorre depois das vanguardas artísticas européias; das vanguardas literárias latino-americanas, contemporâneas das primeiras; da "neovanguarda" européia e norte-americana do pós-guerra; e, no contexto de movimentos sociais e contestações sócio-culturais de dimensão planetária, tanto nos países capitalistas quanto no "socialistas". Em vista disso, a hipótese é de que esse movimento conseguiu congregar em sua estrutura mesma elementos tanto da Vanguarda quanto das Neovanguardas, proporcionando o que se ousa propor neste trabalho como sendo o momento da "vanguarda teatral” latino-americana, próxima daquela ocorrida na Rússia prée pós-revolucionária do início do século. Momento em que pela primeira vez, torna-se perceptível uma teorização local dos processos e objetivações artísticas, capaz de propor uma imagem poética particular, uma poética política. Partindo das premissas teóricas da vanguarda, esse evento não se deu com “atraso” em relação às ocorridas na Europa e na Rússia. A vanguarda teatral latino-americana ocorreu no momento em que poderia ocorrer, no momento em que houve junção de vários fatores convergentes construindo as condições favoráveis à sua manifestação.

\footnotetext{
40 Jorge Schwartz observa que "embora seja comum enquadrar as vanguardas latino-americanas no período dos anos 20 (séc. XX), o decênio no qual os movimentos alcançam seu auge”, prefere apontar a data de 1909, ainda que generosa demais [a seu ver], "ano em que Marinetti lança em Paris o Manifesto Futurista, cujas repercussões foram quase imediatas na América Latina”. Ele conta que "poucas semanas mais tarde, na edição de 5 de abril do prestigioso La Nación de buenos Aires, Rubén Darío, epígono do modernismo hispano-americano, é o primerioa publicar uma ressenha sobre o inovador trabalho de marinetti enquanto poeta, dramaturgo e diretor da revista Poesia”. In: Vanguardas Latino-americanas...Op. cit., p.31.
} 
Como lembra Boaventura, “dependendo das condições sociais e do desenvolvimento da arte em cada país, a Vanguarda assumiria uma forma e uma função diferentes, provocando o surgimento de fenômenos particulares. (...) Além disso, percebese nos países de história mais recente uma atuação diferenciada da vanguarda, assumindo em muitos casos, feições próprias. Em resumo, “a Vanguarda reaviva, nos países de cultura dependente, os elementos especificamente nacionais e primordiais e, ao mesmo tempo, fundamentalmente novos" ${ }^{41}$.

Fica evidente que a vanguarda além de não impor estilo dominante nenhum, foi desenvolvido de forma ambígua, oscilando entre vinculação a partidos políticos conservadores e revolucionários. Mas não há dúvida de que, ao contrário das européias, as vanguardas periféricas desempenharam um papel profundamente revolucionário, tanto as vanguardas russa (do início do século XX) quanto a Latino-americana (do Pós-segunda guerra), idéia que está francamente em oposição ao entendimento amplo de ter sido as vanguardas apenas um movimento conservador e de direita.

\section{Sobre a noção de "latino-americano"}

Tome-se, para começar, o adjetivo composto "latino-americano". Trata-se de uma qualificação muito genérica, derivada da expressão “América Latina”, forjada para dar conta de um grupo de países localizados no “Nuevo Mundo” ou nas “Índias” - assim denominada a América até o século XVI, segundo o historiador franciscano Gerônimo de Mendieta $^{42}$. As origens da expressão “América Latina” envolvem certa controvérsia. Se, por um lado, tem-se a crença de que essa expressão tenha sido forjada inicialmente "nos Estados Unidos para designar os países situados ao sul do Rio Grande”, com uma referência puramente geográfica (FURTADO,1970); por outro, americanistas, como Edmundo O’Gorman, crêem que não passa de mais uma idéia criada pelos europeus

\footnotetext{
${ }^{41}$ Boaventura, Maria Eugênia. Op. cit., p.15.

${ }^{42}$ Apud PHELAN (1986, p.441). Segundo Phelan, o termo América, cunhado por agentes europeus não hispânicos, só passou a ser amplamente usado depois do século XVIII, o que "simboliza el êxito de su desafío al monopolio español de las tierras y las riquezas del nuevo mundo”.
} 
(PHELAN, 1986, p.455). Para John L. Phelan ${ }^{43}$, a origem da expressão "l’Amérique latine” foi concebida na França durante a década de 1860, no contexto das políticas de expansão empreendidas por Napoleão III, iniciadas com a intervenção no México, em 1861(p.442). Napoleão tomaria essa designação como expressão de um velho projeto de unidade dos povos latinos (programa pan-latino) em oposição ao saxonismo e ao pan-eslavismo. Portanto, já a partir dessa época, a idéia de Latinoamérica era usada em oposição à América anglo-saxônica ${ }^{44}$. O “certificado de bautismo” da idéia de América Latina se deu em 1861, segundo Phelan, com o aparecimento dessa expressão, publicada na revista Revue de Races Latines - dedicada à causa do pan-latinismo - num artigo de L.M.Tisserand que dava notícias sobre os últimos acontecimentos do mundo latino. Entre 1861 e 1868, a nova designação era usada somente por seis autores franceses e dois autores hispano-americanos que residiam na França. Os seis autores franceses estavam preocupados com os assuntos mexicanos. O abbé Domenech, na primeira vez que se referiu à Amérique Latine, agregou “c'est a dire, le Mexique, l'Amérique Centrale et l'Amérique du Sud”. O autor se dava conta de que estava usando um termo novo cujo significado tinha que explicar a seus leitores (PHELAN, 1986, p. 454).

Até o século XVIII, outro nome corrente para a região era América Espanhola. Com relação a essa denominação, Germán Arciniegas ${ }^{45}$ comenta que teve um longo processo até que se a abandonasse para cunhar definitivamente a região de América Latina, o que ele atribui à suposição na época de que a Independência nos países hispano-americanos tinha raíz na Revolução Francesa, para não se dizer América Francesa, disse-se América Latina. Mas Arciniegas critica o absurdo de tal designação para uma região habitada em sua maioria por nativos, entre os quais, índios guaranis, mayas e quechuas, que continuavam se expressando em sua língua pré-colombiana. Ele criticou também a repartição geográfica

\footnotetext{
${ }^{43}$ Historiador da Universidade de Wisconsin, Estados Unidos. Ele afirma que "Bolívar, Hidalgo, San Martín y todos que los que iniciaron y realizaron la liberación de esta América, frente al dominio hispano, la llamaron simplemente América, y a sus habitantes americanos. Nombre com el qual se designaron también los habitantes de los Estados Unidos, terminando éstos por convertilo de su exclusividad ante el resto del mundo" (1986, p.442).

${ }^{44}$ Data desse período a “célebre metáfora” de José Enrique Rodó, segundo a qual, a cultura norte-americana, superior aos latinos com relação à “civilização material”, seria representada pela imagem de “Calibán”, materialista; em oposição, à superioridade espiritual dos latinos, representada pela figura de Ariel. Apud (Phelan, 1986, p.448).

${ }^{45}$ Escritor colombiano que cultivou os mais diversos gêneros: contos, ensaios, novelas, autobiografia, comentário jornalístico.
} 
das Américas (América do Norte, Central e do Sul) utilizada até recentemente, pelo fato de se ter incluído o México no mesmo mundo dos “yankes”.

Franklin Rodríguez (1990, p.195) cita uma versão diferente, presente nos estudos de Arturo Ardao, para a aquisição da denominação de "Latino-américa”, segundo a qual, foi um colombiano chamado José María Torres Caicedo ${ }^{46}$ quem começou primeiro, a partir do século XVIII, a denominar nosso continente como latino-américa, pretendendo em primeiro lugar abarcar sob um mesmo conceito a todos os povos de filiação lingüística latina que viviam na América, em oposição aos de filiação lingüística inglesa. Note-se que a abordagem da questão, citada por Rodriguéz e a própria interpretação feita por Arciniegas parecem confirmar a primeira versão dada por Phelan: um daqueles hispano-americano residentes em Paris poderia muito bem ter sido o colombiano José Maria Torres Caicedo de que fala Arturo Ardao.

Para o filósofo mexicano Leopoldo Zea, citado por Rodriguez, "o qualificativo de América Latina está também ‘...ligado à busca da identidade desta nova região. Uma identidade posta em crise pela ruptura política com as metrópoles ibera, em especial com Espanha e Estados Unidos’”. Mas a explicação mais objeitva do surgimento do termo até agora surge no artigo “A Latinidade na América do Sul: Anatole France e Paul Adam” de Regina Salgado Campos ${ }^{47}$, que traz claramente o nome do autor que teria forjado a expressão. Apoiada na obra de Guy Martinière, Campos afirma "que o termo América Latina foi criado por Charles Calvo, latino-americano de origem, em vasta obra de 1862 dedicada a Napoleão III, como ‘expressão sincera de todos os povos de raça latina”. No livro de Guy Martiniére (1982), Aspectos de la coopération franco-brésilienne, ele dedicaria uma seção à “Invenção de um conceito operatório: a latinidade da América”, onde mostraria a história da criação da expressão e o objetivo político e ideológico a que respondera. Campos descreve este contexto da seguinte forma:

A idéia de centrar a influência política, cultural e econômica da França de Napoleão III para com a América recém libertada da colonização espanhola e portuguesa em torno da latinidade está na origem da mal

\footnotetext{
${ }^{46}$ Escreveu obras, cujos títulos são: Ensayos biográficos y de crítica literaria. Paris, Guillaumin, 1863; La Literatura de la América Latina (1879); Unión latinoamericana (paris, 1865); e, Las dos Américas (poema) (Paris, 1856).

${ }^{47}$ In: Perrone-Moisés, Leyla (org.). Do positivismo à desconstrução: Idéias Francesas na América. São Paulo, Edusp, 2004, pp.79-125.
} 
sucedida expedição francesa ao México desse mesmo ano de 1862. O ideólogo da época, o senador Michel Chevalier, explica, em 1863, o papel da França como herdeira das nações católicas da Europa e, portanto, responsável pela manutenção no mundo da chama das raças latinas (2004, p.82-83).

Mas já “a partir de 1880-1885 [seria] suprimido o aspecto católico do conceito inicial, com a emergência do positivismo” ${ }^{48}$, logo após ter sido adotado definitivamente pela linguagem política da Europa, em meados da década 70. E assim teve início a profícua e longa influência espiritual da França sobre a América e, especialmente, a América do Sul, que neste período, adquire desta forma sua “conotação geopolítica moderna” por meio desta estratagema de se vincular à noção de latinidade.

Em vista do exposto, conclui-se que a cunhagem da expressão América Latina veio ao encontro da necessidade da época de forjar uma identidade “própria” da região, que expressasse seu desejo de ruptura e de desligamento radical com Espanha e Portugal. Por isso, a constante na abordagem dos autores referidos acima é a referência exatamente ao processo de indepedência porque passavam essas colônias. Enrique Dussel propõe uma outra interpretação dessa guinada das ex-colônias em direção ao pensamento francês. Ele percebe aí, mais do que um processo de emancipação das ex-colônias, um terremoto cultural que deixaria um vácuo, cujas conseqüências seriam maléficas para o "ser” latinoamericano:

\begin{abstract}
¿No será que un gran terremoto cultural ha producido una ruptura total en la conciencia latinoamericana, en ese tan crucial siglo XIX, impidiéndonos en el presente sentir como propio un pasado latinoamericano? (...) ...porque hispano o iberoamérica existió hasta el siglo XVIII - la Cristiandad colonial, como la llamara Toribio de Mogrovejo1 -, mientras que, el proceso de universalización y secularización del siglo XIX, se constituyó esencialmente por el aporte francês - en lo cultural -, y anglosajón - en lo técnico. Desde ese momento el mundo "español" es ya marginal en América latina.
\end{abstract}

Este texto de Dussel dá o tom da busca que atravessaria todo o século XX da América Latina até desembocar de forma mais ampla na discussão da identidade e da nacionalidade latino-americanas, sua utopia e sua encruzilhada; temas que seriam objeto principalmente da Sociologia que aportava na região com todo vigor na segunda metade do

\footnotetext{
${ }^{48}$ Campos, Regina Salgado, op. cit., p.83.
} 
século XX. Também como conseqüência do aporte daquele positivismo inicial em fins do século XIX.

Pode ser conseqüência desse "terremoto cultural”, enfim, o fato de a formação de uma “consciência latino-americana” ser um "fenômeno recente, decorrência dos novos problemas colocados pelo desenvolvimento econômico e social da região nos três últimos decênios”, quando a América Latina deixou então de ser uma expressão geográfica para “transformar-se em uma realidade histórica”, segundo o economista brasileiro, Celso Furtado $^{49}$. Pensar a especificidade da denominação "latino-americano” é uma necessidade que se impõe a todos quantos queiram refletir sobre qualquer dos complexos fenômenos da região. No campo da produção teatral, entendida como uma epifania cultural, social e política, a compreensão deste qualificativo “latino-americano” remete a um processo histórico já em andamento que diz muito sobre o tipo e o caráter do teatro produzido na região. A partir da segunda metado do século XX, este teatro entra em diálogo direto com o "pensamento latino-americano" 50 , cujas propostas de "interpretação da realidade e da história” do continente, desempenharia um papel fundamental para produção de uma grande parcela de artistas do período (RODRIGUEZ, 1990, p.194). A partir do momento em que a Sociologia Crítica Latino-americana ${ }^{51}$ se consolida, é possível encontrar um pensamento crítico local, complexo, resultado de uma dessas operações de recepção,

\footnotetext{
${ }^{49}$ Furtado, Celso. (1970, pp.20-21)

50 “O campo de investigação abarca diversas expressões do homem latino-americano, como a História , a Cultura, a Linguagem, a Política etc. O instrumental teórico utilizado provém da História das Idéias Latinoamericanas, assim como de diversas correntes filosóficas ocidentais. (...) O aspecto central e ponto de partida do "Pensamento Latino-americano" é o estudo da História das Idéias na América Latina dos distintos ramos do conhecimento. O Historicismo, o Existencialismo, o Estruturalismo, o Marxismo e a Epistemologia são os instrumentos teóricos mais importantes, dentre as que se pretende adaptar para criar as fases de uma Filosofia Latino-americana autêntica” (RODRÍGUEZ, 1990, nota de rodapé no.41, p.204).

51 “A Sociologia expressou as profundas transformações das sociedades latino-americanas: acompanhou o processo de construção do Estado e da Nação, problematizou as questões sociais, analisou os efeitos da mundialização das conflitualidades, sempre se mantendo em um diálogo internacional múltiplo. (...) Podemos identificar seis períodos na Sociologia na América Latina e no Caribe: I) a herança intelectual da Sociologia (Século XIX até início do Século XX); II) a Sociologia de cátedra (1890-1950); III) o período da "Sociologia Científica" e a configuração da "Sociologia Crítica" (1950-1973); IV) a crise institucional, a consolidação da "Sociologia Crítica" e a diversificação da Sociologia (1973-1983); V) a Sociologia do autoritarismo, da democracia e da exclusão (1983-2000); VI) a consolidação institucional e a mundialização da Sociologia da América Latina (desde o ano de 2000).” In: TAVARES-DOS-SANTOS, José Vicente and BAUMGARTEN, Maíra. Sociology's contribution in Latin America to sociological imagination: analysis, critique, and social commitment. Sociologias. [online]. July/Dec. 2005, no.14 [cited 14 April 2006], p.178-243. Available from World Wide Web: <http://www.scielo.br/scielo.php?script=sci_arttext\&pid=S1517$45222005000200009 \& \operatorname{lng}=$ en\&nrm=iso $>$. ISSN 1517-4522.
} 
reelaboração, adaptação de teorias sociológicas estrangeiras, que será acessado pelos artistas, seguindo de perto os princípios brechtianos, segundo o qual a arte não prescinde dos conhecimentos propiciados pela ciência.

\section{Alguns Pressupostos}

\section{O Nuevo Teatro como a primeira vanguarda teatral latino-americana}

Por ocasião do curso de Mestrado $^{52}$, surgiram questões que não puderam ser plenamente desenvolvidas, mas que permaneceram como uma sombra sobre o tema. Uma dessas questões refere-se exatamente ao papel desempenhado pelas vanguardas históricas européias e russas sobre o conjunto dos movimentos artísticos latino-americanos que explodiriam ao longo do século XX. A radicalidade da ruptura apresentada pelas vanguardas em seus contextos de origem reverberou de modos distintos e em diversas "levas” para o "resto do mundo", provocando e insuflando agitações e inovações jamais vistas.

A peculiaridade da América Latina fez com que a recepção dessa influência vanguardista também fosse de modo peculiar. Enquanto na Europa e na Rússia do início do século XX, as vanguardas emergentes envolveram várias modalidades artísticas a ponto de ser possível, na Rússia e na Alemanha, por exemplo, a relação estreita entre música, dança, artes plásticas e teatro, diferentemente na América Latina, nos anos 20, isso não ocorreria devido em parte à pouca força do movimento teatral, e de outra, ao desenvolvimento pontual do teatro comercial. Nessa região do globo, toda a movimentação cultural do modernismo se

\footnotetext{
${ }^{52}$ Intitulada Manifestações Contemporâneas do Teatro Político: estudo da produção e da poética da Companhia do Latão e do El Galpón (Brasil e Uruguai), orientada pelo Prof. Dr. Sedi Hirano e defendida em junho de 2002 nesta Universidade. Este tese representa de certa forma continuidade e aprofundamento do tema desenvolvido na minha dissertação, cujo objetivo, na época, era o estudo comparativo de dois grupos teatrais da América Latina, previamente selecionados a partir de certos critérios tais como o do relacionado ao caráter de sua produção artística: deveria necessariamente estar vinculada a vertentes do chamado Teatro Político. Uma das questões era saber se a produção desses grupos poderia realmente ser qualificada de "teatro político”. E, para isso, impunha-se a discussão do que significava teatro político, suas formas de manifestações e se ainda eram válidas tais manifestações na contemporaneidade e de que forma isso seria possível.
} 
restringiria praticamente ao âmbito das artes plásticas e da Literatura; o teatro passaria quase desapercebido, salvo em alguns países como o México, Argentina ou o Uruguai, onde os germens do movimento de teatro independente já davam seus primeiros sinais. Quando, nos anos 50, no período do pós-guerra, uma nova onda vanguardista se espalha nos países centrais - a chamada neo-vanguarda - como uma forma de dar conta dos horrores das duas grandes guerras da primeira metade do século XX, só então, poder-se-á detectar na América Latina o embrião do que viria a ser a "vanguarda teatral latinoamericana”, que floresceria nas duas décadas seguintes: os anos 60 e 70 do século XX. O movimento do Nuevo Teatro representa de certo modo a emergência da vanguarda teatral na América Latina, que se constituiria a um só tempo como arte vanguardista e revolucionária, com aspectos semelhantes àquela ocorrida na Rússia dos anos 20. Se não se pode afirmar peremptoriamente sobre relações diretas entre este contato da América Latina com a Rússia dos anos 20 parece ser um pouco forçado, um evento não muito alardeado faz essa ponte, ainda que de forma tênue e indireta, mas definitiva: o teatrólogo Seki Sano, como será mostrado mais tarde.

Depois de todas as experiências radicais das vanguardas artísticas e políticas, européias e russas, depois das novas reedições dos princípios vanguardistas dos anos 50, ou da neovanguarda do pós-guerra, o movimento teatral colombiano nascente teria à sua frente uma fonte inesgotável onde saciar sua fome e sua sede de arte comprometida com a Vida e com a Beleza, não com a vida ou a beleza em geral, mas com a sua vida e com o seu modo de entender o belo.

O que representou o "retorno" ao "primitivo" nas vanguardas européias suscitou na AL tanto a recuperação de suas culturas indígenas pré-colombianas, civilizações estilhaçadas, sob o jugo de cinco séculos de extermínio, conquista e colonização; quanto a recuperação das múltiplas formas que vigoraram durante os três séculos do teatro colonial. Sob o influxo dos princípios vanguardistas, o rearranjo teatral latino-americano se orienta assim a partir de duas linhas de força: a do futuro e a do passado, vanguarda e tradição, as duas grandes matrizes estéticas que dariam origem à multiplicidade de formas teatrais organicamente plasmadas, engendrando o que mais tarde se tornaria o movimento do Nuevo Teatro. 


\section{Vinculação a uma estética socio-política}

Que o Nuevo Teatro Latinoamericano esteja fortemente vinculado a uma vertente do teatro político, engajado e comprometido socialmente, inúmeras análises não têm deixado margem a dúvidas. Trata-se, portanto, de constatação fundamentada em pesquisas de estudiosos latino-americanos e estrangeiros como comprovam as publicações de Leon F. Lyday e George W. Woodyard ${ }^{53}$ (1976); Beatriz Rizk ${ }^{54}$ (1987); Diana Taylor ${ }^{55}$, Elena de Costa $^{56}$ (1992); Adam Versenyi ${ }^{57}$ (1993); Judith Weiss ${ }^{58}$ (1993), para ficar só nestes. Na verdade, o Nuevo Teatro representa o ponto de chegada ou o auge de um processo cultural levado às últimas conseqüências, uma vez que é possível detectar nele a construção subjacente de uma linha de continuidade cultural $^{59}$, na qual o elemento de crítica social e política sempre estiveram presentes em sua produção artística, ainda que de forma ambígua e mimetizada em certos períodos como o do teatro colonial. É verdade que se trata de uma linha tortuosa, oscilante, ou melhor, ziguezagueante, mas o seu trajeto, irregular, circunda quase todo o mapa geográfico da América Latina. Essa irregularidade do trajeto é muitas vezes confundida com descontinuidade. Essa confusão espaço-temporal tem o único efeito de tornar ainda mais inacessível a percepção dos processos culturais da região, gerando um volume crescente de diferentes abordagens literárias e histórico-sociológicas. Para entender a complexidade do movimento do Nuevo Teatro, pode ser estimulante traçar a situação em que se encontra o debate sobre o "teatro latino-americano", a partir da produção crítica mais recente.

Foi dito no parágrafo anterior sobre a aparente irregularidade de uma linha de cultura teatral específica na América Latina que confundida com descontinuidade leva à confusão,

\footnotetext{
${ }^{53}$ Dramatists in Revolt: the New Latin American Theater. Austin, University of Texas Press, 1976.

${ }^{54}$ El Nuevo Teatro Latinoamericano: una lectura histórica. Minneapolis: Instituto Prisma,1987.

${ }^{55}$ Theatre of Crisis: Drama and Politics in Latin América. Kentuchy: The University Press of Kentuchy, 1991.

${ }^{56}$ Collaborative Latin American Popular Theatre. Nova York, Peter Lang, 1992.

${ }^{57}$ Theatre in Latin América: Religion, politics, and culture from Cortes to the 1980s. Cambridge, University Press, 1993.

${ }^{58}$ Latin American Popular Theatre. Albuquerque, University of New México Press, 1993.

59 Judith Weiss fala da “...evolução de uma linha histórica que leva diretamente ao Nuevo Teatro” (1993, p. 4) [ "...in the evolution of a historical line that leads directly to the Nuevo Teatro Popular"]. O termo "evolução" remete à idéia de "progresso”, daí a preferência para o uso do vocábulo “continuidade”.
} 
dificultando a abordagem analítica dos processos culturais. Em função disso, percebe-se, na maioria das obras históricas sobre o teatro latino ou hispano-americano, um desfilar de referências a praticamente os mesmos eventos e os mesmos nomes de autores e diretores, os quais deixaram sua marca inscrita na tradição teatral. Há períodos em que essa marca teatral é mais visível no Peru e México; depois na região do Rio da Prata, na Argentina e no Uruguai; outras vezes, ela escala os Andes e se estabelece temporariamente no Chile; depois vai para o Peru e Colômbia, e assim por diante. Ainda que cada país guarde sua especificidade, o pano de fundo histórico da colonização enlaça o conjunto dos países numa situação, cuja similaridade é irrefutável.

O compartilhamento de uma história de terra conquistada, de colonização, de uma cultura vencida, de instabilidade política e econômica e de uma dependência externa crônica em termos econômicos gera muitos pontos em comum, a despeito das diferenças particulares entre os 25 países que configuram a região como, por exemplo, as distintas combinações entre os povos nativos e as ondas de imigração européia e africana. Do mesmo modo a cultura teatral erra por rotas de forma irregular, mas constante. Assim, a linha de tradição da cultura teatral das “Américas Latinas” vai se deslocando de país em país, oscilando continuamente de uma região para outra, como faz uma velha companhia de teatro mambembe até cobrir no final todo o espectro da região. Assim também se explica, por exemplo, a intensa produção teatral no Peru do início do século XVI e seu arrefecimento na virada do mesmo século; para, em seguida, ser detectado um aumento de produções teatrais no México, Argentina, e Uruguay, durante os séculos XVIII e XIX. Durante o século XIX, houve um relativo crescimento da produção teatral na maioria dos países da região.

Demarcar essa linha de ocorrências teatrais mais significativas no conjunto dos países constituintes da região foi tarefa a que se propuseram autores como Judith Weiss ${ }^{60}$ e Adam Versenyi $^{61}$, os quais, esforçaram-se para dar conta da história do teatro latino-americano desde seus primórdios pré-colombiano e colonial até o momento contemporâneo. Assim, “os inícios do teatro latino-americano podem ser traçados pelo encontro de culturas de três continentes: América, África e Europa”62 e suas respectivas práticas teatrais. Nessa

\footnotetext{
${ }^{60}$ Weiss, Judith. Latin American Popular Theatre. Albuquerque, University of New México Press, 1993.

${ }^{61}$ Versenyi, Adam, “Theatre in Latin América...”, op. cit.

${ }^{62}$ Weiss, Judith. Latin American Popular Theatre, op. cit., p.11.
} 
colocação, fica patente o fato de que Weiss considera como teatro, formas que ela chama de “dança-drama, ritual-drama e formas pré-teatrais não apenas porque elas constituem as origens do teatro popular (grifo nosso) nas Américas, mas também - e igualmente importante - porque muitos podem de fato por si mesmos serem classificados como teatro"63. Na classificação do que seja teatro para Weiss, como citada acima, aparece ainda um termo fundamental: o vocábulo "popular”. A perspectiva do popular marca o viés de todo o seu trabalho, fazendo com que ela abra uma brecha em proposições tradicionais de muitos historiadores, segundo os quais, seria "impossível falar da emergência de um teatro especificamente americano antes dos últimos anos do período colonial, no fim do século XVIII” (p.). Sem contestar diretamente, Weiss demonstra no corpo de seu trabalho uma margem ampla de produções e práticas artísticas populares deixadas fora do marco destes estudiosos, em virtude de eles "terem coberto primeiramente o estudo da literatura dramática e a evolução do teatro formal (grifo nosso) em ambientes urbanos”64, fortemente derivado do teatro europeu. Ela recorre a uma distinção conceitual importante entre cultura oral e cultura escrita para se referir ao "popular" no teatro latino-americano em seus primórdios. O choque que marcou o encontro entre o americano e o europeu. As “culturas orais e não literárias foram amplamente identificadas com a impotência e a marginalidade; enquanto a cultura literária das elites, cada vez mais identificada com o poder e a autoridade”, incluindo o poder crescente do setor crioullo em relação a Espanha e Portugal. As múltiplas combinações das relações entre essas duas culturas dariam origem à complexidade e à heterogeneidade da cultura latino-americana do século XX. Deste modo, a obra de Weiss ilumina um lado obscuro do teatro colonial latino-americano tradicionalmente considerado, numa leitura no mínimo simplista, mera transplantação da cultura teatral européia, nos formatos dos autos, das entremeses, dos corrales dos teatros português e espanhol do Siglo de Oro.

\footnotetext{
${ }^{63}$ A citação no original em inglês: "we decide to include in our study such forms as dance drama, ritual drama and pretheatrical forms not only because they constitute the origins of popular theatre in the Americas, but also - and equally importantly - because many can in fact themselves be categorized as theatre”, in op. cit. p. 12. Weiss reconhece que esse tipo de manifestação ritualística é contestada como forma teatral. Nessa mesma página, ela afirma: "The types of culture with wich we are dealing have contributed theatrical forms or types of performance whose legitimacy as such is sometimes challenged”.

${ }^{64}$ Weiss, Judith. Latin American Popular Theatre, op. cit., p.11.
} 
Embora considere as formas ritualísticas dos nativos americanos como teatro, Weiss não se detém nem na sua descrição nem na sua análise, desenvolvendo seu estudo a partir dos resultados da transculturação, da aculturação e do sincretismo por que passou o choque ou o confronto das três culturas no período da conquista e pós-conquista, sendo classificado sob um conceito geral de teatro colonial. Quem recua mais no tempo para mostrar a cultura nativa americana antes da conquista, ainda que sucintamente, é o trabalho de Adam Versenyi que se move numa “estrutura de tempo que vai dos dias pré-colombianos aos dias atuais”65. Entretanto, ele o faz, negando a estas formas ritualísticas pré-colombianas sua natureza teatral; para ele não se trata de "verdadeiro teatro”: “A guerra ritual e as oferendas em sacrfício não são, por si sós, verdadeiro teatro. No teatro se diferenciam os atores dos espectadores, enquanto que na guerra e no sacrifício não existe essa distinção” ${ }^{66}$.

Frente a essa oposição no modo de se considerar as práticas culturais pré-colombianas de dois autores estrangeiros, tomados como ponto de partida para abordar o teatro latinoamericano, fica já evidenciada a vigência do debate ainda em aberto sobre essa questão. Pergunta-se: pode-se chamar de teatro os rituais religiosos primitivos? Note-se que a publicação de ambas as obras são do mesmo ano: 1993, ou seja, relativamente, recente.

É principalmente na Modernidade que esse debate vem à tona. A partir das questões colocadas pelas vanguardas européias, surgem dois pontos de vista discordantes: de um lado, os que não consideram aquelas práticas mítico-religiosas, as danças e os rituais dos povos ditos "primitivos" como teatro. Antes, seriam tratadas como formas "pré-teatrais", e seu caráter de espetacularização reteria sim em sua estrutura vários elementos teatrais (grifo nosso), mas não permitiria denominá-lo como teatro entendido nos moldes da cultura européia e ocidental. De outro lado, o grupo dos que pensam exatamente o contrário: todas as formas de rituais religiosos já seriam em si “teatro”, no pleno sentido da palavra. Weiss se alinha, sem muita convicção, nessa última tendência. Já Taylor e Versenyi, alinhados com a primeira vertente, indicam a contudência de argumentos tais como a de que tudo de que se tem notícia sobre os nativos americanos anterior à Conquista foi registrado pelos

\footnotetext{
${ }^{65}$ Versenyi, Adam. Theatre in Latin América: Religion, politics..., op.cit., p. prólogo.

${ }^{66}$ Versenyi, Adam. Theatre in Latin América: Religion, politics..., op.cit., p.11. Na tradução em espanhol: La guerra ritual y las ofrendas en sacrifício no son, por si solas, verdadero teatro. En el teatro se diferencian los actores de los espectadores, mientras que en la guerra y el sacrifício no existe esta distinción”.
} 
conquistadores e padres missionários espanhóis em seus relatos e crônicas sobre as “Índias”, de modo que estes documentos históricos informam mais sobre o comportamento e a visão de mundo dos europeus daquela época do que da cultura pré-colombiana propriamente dita ${ }^{67}$. Até porque, antes de os invasores serem despertados para o interesse de registrar informações sobre a organização, os ritos e cerimoniais, a arquitetura e todo o sistema de vida dos ameríndios, eles destruíram quase tudo primeiro ${ }^{68}$.

Ainda sobre o debate a cerca dos rituais pré-hispânicos, se seriam teatro ou não, pode ser esclarecedor observar como o assunto é considerado por historiadores e estudiosos locais. Na Colômbia, Maria Mercedes Jaramillo ${ }^{69}$ e Fernando González Cajiao ${ }^{70}$, por exemplo, referem-se diretamente a essas práticas como teatro, afirmando tratar-se de uma modalidade de teatro presente na religiosidade dessas sociedades nativas americanas, como mostra o prólogo de uma das obras: "este libro, en efecto, comprueba que el teatro es vieja tradición entre nosotros; no nació ayer, ni siquiera anteayer: es uma arte que nos acompaña muy probablemente desde los tiempos precolombinos”, ${ }^{\text {, }}$.

Sem pretender entrar neste debate, uma vez que não é esse o tema do presente estudo, a referência a ele se faz apenas em função de sua pertinência com o movimento do Nuevo Teatro. Não deixa, porém, de ser significativo que só no curso do século XX surge este questionamento e a necessidade de refletir sobre ele. A reivindicação do reconhecimento destas práticas como sendo uma forma de teatro por um grupo de estudiosos parece estar mais ligada tanto a um desejo de acerto de contas com o passado de dominação e colonização como também a uma necessidade de auto-afirmação e de confronto com o ponto de vista eurocêntrico. Guardada as devidas proporções, lembra de certo modo a polêmica sobre a "humanidade” ou a “animalidade” dos ameríndios que envolveu o padre

\footnotetext{
${ }^{67}$ Esse tema já foi tratado por semióticos e antropólogos como em obras como A Conquista da América de Tzvetan Todorov e em A visão dos vencidos de Miguel León-Portilla.

${ }^{68}$ Pode-se ler na obra citada de Versenyi, o seguinte trecho:“En latitudes más meridionales, en Mesoamérica y Sudamérica, la documentación relativa a las actividades religioteatrales de los indígenas en los tiempos precolombinos se ve muy empobrecida por la ausencia de las órdenes mendicantes. Nuestra comprensión de las mesmas se vê también dificultada por el celo de personas como el obispo Diogo de Landa, que destruyó cuantos libros o códices indígenas pudo descobrir” (1993, p.18).

${ }^{69}$ Mercedes Jaramillo, Maria.“La autonomia cultural en el teatro colombiano”, capturado 2007 do site: http://iacd.oas.org/interamer/Interamerhtml/RodrVerghtml/Verg34_Jaram.htm.

${ }^{70}$ González Cajiao, F. “El teatro precolombino siempre fue callejero”. In Conjunto Teatro Latinoamericano. Cuba: Casa de las Américas, 1992.

${ }^{71}$ González Cajiao, F. Historia del teatro en Colômbia. Bogotá: Instituto Colombiano de Cultura, 1986, p. 8.
} 
Las Casas, conquistadores, pensadores e funcionários da corte na metrópole ${ }^{72}$, no momento inicial da colonização. Curiosamente, será na Europa, sede da ratio humana da modernidade, que se assistirá o renascer do teatro ou drama ritual. Obviamente, muito distinto daquele das sociedades "primitivas", de modo que é preciso distinguir em que consiste esse teatro ritual contemporâneo.

O teatro ritual teria tido sua origem a partir de certos princípios vanguardistas relacionados à valorização das “artes primitivas”, expressos principalmente pelo pensamento de Antonin Artaud. Mas só mesmo depois dos anos 60 do século XX seu desenvolvimento atingiria a plenitude com as propostas de encenação do diretor polonês Jersy Grotowski; cujas peças teatrais seriam vistas por alguns críticos como a aplicação dos princípios artaudianos à cena; o que é negado pelo diretor ${ }^{73}$. De qualquer modo, ele instauraria uma prática teatral que daria origem por sua vez a distintos desdobramentos do teatro ritual. Encontra-se em seu teatro pobre a afirmação de que “o teatro, quando ainda fazia parte da religião, já era teatro: libertava a energia espiritual da congregação ou tribo, incorporando o mito e profanando-o, ou melhor, superando-o",74. É bom lembrar, contudo, que Grotowski situa conscientemente o seu teatro sagrado num mundo totalmente secular onde não há mais nenhuma possibilidade de "identificação do grupo com o mito", de modo que a única forma de se relacionar com esse mito seria por meio da confrontação e da violação do organismo vivo do ator. Patrice Pavis dirá que “o ritual encontra seu caminho na apresentação sagrada de um acontecimento único: ação não imitável por definição, teatro invisível ou espontâneo, mas, sobretudo, “desnudamento sacrificial do ator”75. Além disso, a certa altura ele afirma também que todo teatro não deixa de ter seu próprio ritual. De qualquer maneira, o teatro de Grotowski investe no estudo dos mitos religiosos e nos arquétipos da condição

\footnotetext{
72 Todorov escreve: "Las Casas e outros defensores da igualdade acusaram tão freqüentemente seus adversários de terem tomado os índios por animais, que se pode suspeitar de que houve exagero”. E depois: “O debate entre partidários da igualdade e desigualdade dos índios e dos espanhóis atingirá seu apogeu, e encontrará ao mesmo tempo uma encarnação concreta, na célebre controvérsia de Valladolid, que em 1550, opõe o erudito e filósofo Gines de Sepúlveda ao padre dominicano e bispo de Chiapas, Bartolomé de Las Casas” ( 2003, pp. 212-219).

${ }^{73}$ Cf. afirmação de Grotowski: “Freqüentemente, perguntam-me sobre Artaud quando falo em 'crueldade', embora suas formulações fossem baseadas em premissas diferentes e tivessem objetivo diferente. Artaud era um sonhador extraordinário, mas seus escritos têm pouco significado metodológico porque não são frutos de longa pesquisa prática. São uma profecia espantosa, não um programa” (1971, p.10).

${ }^{74}$ Cf. Em busca de um teatro pobre. Rio de Janeiro: Civilização Brasileira, 1971, p. 9. Ver também do mesmo autor Teatro das origens.

${ }^{75}$ Pavis, Patrice. Dicionário de Teatro. São Paulo: Perspectiva, 2005, p. 346.
} 
humana, inaugurando uma modalidade teatral que renderia muitos frutos posteriormente, chamando a atenção de estudiosos e artistas para a investigação das práticas teatrais presentes nos rituais dos povos primitivos.

A polêmica do drama ritual continua vigente, mesmo que já tenha se tornado uma das modalidades consistentes do que se costuma chamar performances, isto é, o que se denomina contemporaneamente "teatro ritual"76 é uma das cinco tendências das formas mistas e híbridas conhecida como as performance art $^{77}$, cujo pressuposto entre outros é a interação entre as diversas linguagens artísticas, promovendo uma contaminação entre ou o apagamento de suas fronteiras, experiência especialmente difundida no contexto da cultura pop norte-americana. Além dessa tendência, o teatro ritual englobaria também desde imitações do trabalho de Grotowski até a suposta recuperação de formas autênticas do teatro primitivo $^{78}$. É por isso que González Cajiao pode afirmar sem incorrer em nenhum equívoco que: "Estas antiguas formas teatrales de América, sin embargo, podrían tener ahora la mayor actualidad, ya que, aunque parezca paradójico, algunas de sus técnicas podrían ejemplificarse hoy como recursos de la más alta modernidad”79. Elas têm, de fato, no contexto da modernidade latino-americana e ocidental, certa atualidade como pode ser constatada no crescente interesse sobre o assunto por meio do aumento de artigos sobre

\footnotetext{
${ }^{76}$ Cf. Artaud (1964); Girard (1974); Turner (1982) e Schechner (1985).

${ }^{77}$ Um pressuposto, na verdade, da arte contemporânea em geral. A performance surgiu nos anos 60 e quase se confunde com o Happening. "Ela associa, sem preconceber idéias, artes visuais, teatro, dança, música, vídeo, poesia e cinema. (...) Enfatiza-se a efemeridade e a falta de acabamento da produção”. Suas cinco tendências seriam: a body art; exploração de espaço e tempo pelo deslocamento; apresentação autobiográfica; cerimônia ritual e mística; e o comentário social, segundo Nouryen ( ), na referência de Patrice Pavis em seu Dicionário de Teatro, op. cit. p.284.

${ }^{78}$ Num artigo de Nancy Lee Ruyter, intitulado “Ancient Images: The Pre-Cortesian in 20th-Century Dance Performance”, a autora descreve quatro manifestações diferentes do que estão denominando contemporaneamente teatro ritual, embora ela use o termo genérico performance. Segundo o artigo, tratam-se dos espetáculos de danças “aztecas” do Ballet Folklórico de México (profissional); danças “aztecas” apresentadas por músicos e dançarinos do conjunto Conchero, (dança de rua); o grupo Mexica de dançarinos e percusionistas (tambores) apresentam danças e rituais “aztecas”; e, por último, o grupo de dançarinos mexicano-americanos chamado Azteca, que se apresentam em universidades nos Estados Unidos. Todos pretendem a autenticidade na recuperação do vocabulário de gestos e movimentos dos rituais aztecas, a partir de pesquisas em documentos históricos, fontes pictóricas e escritas, como as crônicas e os códices dos padres missionários. Ao serem questionados sobre isso, os grupos respondem que sua dança foram transmitidas de geração em geração a partir dos tempos pré-hispânicos. In: Gestos: teoria y practica del teatro hispânico, ano 11, no. 21, abril, 1996, pp.145-155.

${ }^{79}$ González Cajiao, F. “El teatro precolombino...”, op. cit., p.7.
} 
rituais e montagens teatrais sobre mitos indígenas, em revistas especializadas em teatro como Gestos $^{80}$ e $T D R^{81}$.

Entretanto, para o que interessa nesse momento, é suficiente saber que teatro ou não, o caráter espetacular ${ }^{82}$ inerente aos rituais dos nativos americanos foi habilmente aproveitado pelas ordens eclesiásticas no empreendimento da cristianização do Nuevo Mundo ${ }^{83}$. Diana Taylor inicia a introdução do seu Theatre of Crisis, denunciando o papel ativo do teatro "na continuidade da colonização da América Latina a partir das peças espanholas usadas para cristianizar e colonizar as populações nativas das Américas no século XVI”, ${ }^{\text {”4 }}$ E cita enfaticamente a analogia de Maria Sten: “o teatro foi para a conquista espiritual do México o que os cavalos e os canhões foram para a conquista militar”85.

O trauma insuperável da violência da Conquista pesa ainda sobre os escombros de uma América Latina destroçada. "Estas sociedades diversas foram substituídas por um sistema homogeneizante que converteu todos os grupos indígenas, com suas muitas diferenças, em um ‘Outro’ controlável”86. Dera-se o início da “guerra das imagens e a ocidentalização da América”87. Taylor informa com concisão:

A colonização impôs a redefinição e renomeou o território conquistado: o "novo mundo", as “Índias”, a "Nova Espanha”. Assim como as fronteiras geográficas foram remapeadas numa nova entidade política, a ideologia foi alterada para abrir caminho a uma nova hegemonia, desenhando

\footnotetext{
${ }^{80}$ Cf.: Arata, Luis O. “Performing the Maya Vision of creation from Popol Vuh”. In: Gestos: Teoría y Práctica del Teatro Hispánico, año 12, no. 23, abril 1997, pp.115-129.

${ }^{81}$ A título de exemplo: Edwards, Emily D. "Firewalking: a contemporary ritual and transformation". In TDR: The Drama Review, vol. 42, no. 2 (T158), Summer 1998, pp. 98-113.

${ }^{82}$ Conferir Apêndice 2 sobre o teatro pré-colombiano.

${ }^{83}$ Cf.: (Versenyi, 1993; Weiss, 1993; Taylor, 1991).

${ }^{84}$ Taylor, Diana; op. cit. p.1.

${ }^{85}$ No original: “...theatre was for the spiritual conquest of Mexico what horses and gunpowder were for the military conquest”. In: Sten, Maria. Vida y muerte del teatro Náhuatl; apud (Weiss, 1993, p.1).

${ }^{86}$ Taylor, Diana; 1991, p.2. Cf. original: "Colonization entailed the redefiniction and renaming of conquered territory: the "New World", the "Indies", the "New Spain". Just as the geographical boundaries were remapped into new political entities, ideology shifted to make way for a new hegemony, drawing new lines of demarcation to separate the "civilized" from the "barbarian", the urban from the rural , the literate from those grounded in orality. (...) The decimated area was inscribed with the new social, political, and religious order, with its own codes and its own spectacular displays of power. Spectacle, though still key, inverted the preColumbian pattern. Spectacle was not power, as before; now it supported power. The theatricality, the pomp, and the ceremony of religious and secular celebration contributed to the legitimation of the new order; they helped recast the indigenous people'loss of their world as their gain of Christendom and eternal salvation; they served to maintain order and hierarchies by inspiring terror in the native audience that witnessed public executions, acts of totrture, and other spectacles of awesome power”.

${ }^{87}$ Gruzinski, Serge. “A guerra das imagens e a ocidentalização da América”. In: Vainfas, Ronaldo (org.). América em tempo de conquista. Rio de Janeiro: Zahar, 1992, p. 198.
} 
novas linhas de demarcação para separar o "civilizado" do "bárbaro", o urbano do rural, o literato daqueles fundados na oralidade. (...) As áreas dizimadas foram inscritas com a nova ordem religiosa, política e social, com seus próprios códigos e sua própria exibição espetacular de poder. O espetáculo, embora ainda chave, foi o avesso do modelo pré-colombiano. O espetáculo não era mais poder, como antes; agora ele era o suporte do poder. A teatralidade, a pompa e a cerimônia das celebrações religiosas e seculares contribuíram para a legitimação da nova ordem; elas ajudaram os indígenas a remodelar e a refundir a perda do seu mundo, no ganho da religião cristã e da salvação eterna; eles serviram para manter a ordem e as hierarquias ao inspirar terror no público nativo que testemunhava execuções públicas, atos de tortura e outros espetáculos de poder impressionantes $^{88}$.

\section{Cultura de resistência e continuidade cultural}

O Nuevo Teatro tem a ver tanto com a cultura da resistência de que fala Marta Traba ${ }^{89}$ quanto com a continuidade cultural da "ibero e hispanoamerica" referido por Carlos Fuentes. Tem a ver tanto com a canção de protesto quanto com a estética da fome do movimento do cinema novo. O debate sobre a recepção das neo-vanguardas no âmbito das artes plásticas, da literatura, da música e do cinema, produziu discursos polêmicos, que convergiram, por um lado na divisão interna dos artistas dentro da esfera de cada uma dessas modalidades artísticas; e por outro, num posicionamento revolucionário e mais radical de certa fração da produção da arte no explosivo período dos anos 60-70 do século $\mathrm{XX}$.

Garcia Canclini aponta a data de 1952, depois da recuperação da Segunda Guerra Mundial e terminada a Guerra da Coréia, como o marco em que os "países centrais reorganizam a economia capitalista e tornam-se capazes de exercer uma pressão monopolista mais efetiva sobre os dependentes" mundo”. Isso vai por fim ao quadro de relativa acumulação de capital que vinha desde o início do século em vários países latino-americanos, impulsionados pelo surto industrial, mais explícito após a década de 30 (séc.XX). Já em finais da década de 50, a política de

\footnotetext{
${ }^{88}$ Taylor, Diana; op. cit., p.3.

${ }^{89}$ Artigo de Marta Traba, publicado na revista Vidas das artes, ano 1, número 7, Rio de Janeiro, São Paulo, Jan./Fev. de 1976.

${ }^{90}$ Garcia Canclini, Nestor. A produção simbólica. Rio de Janeiro, Civilização Brasileira, 1979, p.81.
} 
substituição de importações se esgota e o capital internacional bate em retirada por meio de sua política de concentração da massa de negócios entre eles mesmos, entre os próprios países centrais, como constatam os números que Sedi Hirano descreve abaixo:

Os indicadores econômicos demonstraram que, entre os anos 50 e 70, a participação do Terceiro Mundo nas exportações mundiais se reduziu drasticamente, passando de 30 para menos de $20 \%$, e a participação latino-americana, nesse mesmo período, nas exportações sofreu uma queda abissal: de 12 passou para $5 \%{ }^{91}$.

Paralelamente à “fuga” de capitais estrangeiros ${ }^{92}$, teve início nesse mesmo período uma nova etapa da penetração cultural norte-americana na América Latina. No âmbito das artes plásticas,

A criação de um Conselho Internacional por parte do Museu de Arte Moderna de Nova York (1952), que exportou amostras de pintura norteamericana de vanguarda para as principais capitais do nosso continente, o apoio econômico da União Pan-Americana, da CIA e das empresas multinacionais (Esso, Standard Oil, Shell, General Motors, General Eletric) a museus, revistas, artistas e críticos latino-americanos configuraram uma agressiva campanha que, por diversas vias, às vezes encobertas, promovia um mesmo projeto: difundir uma experimentação formal aparentemente despolitizada, sobretudo o expressionismo abstrato, como alternativa ao realismo social, ao muralismo e a toda corrente preocupada com a identidade nacional dos nossos países ${ }^{93}$.

Não só nas artes plásticas, em outras esferas da arte também houve essa promoção das experiências de vanguarda estimuladas financeiramente por grupos industriais latinoamericanos e empresas internacionais:

Para atualizar a arte 'latino-americana' em relação à Europa e aos EUA, a Metalúrgica Matarazzo, em São Paulo; o Instituto Di Tella, em Buenos Aires; a General Eletric, em Montevidéu; o Aço do Pacífico, no chile; a Esso, na Colômbia, ofereceram aos artistas plásticos, a conjuntos teatrais e musicais, amplas salas de exposição, prêmios e prestígio, bienais com júris de Nova York, Londres e Paris ${ }^{94}$.

\footnotetext{
${ }^{91}$ Hirano, Sedi. “América Latina no novo contexto mundial”. In: Scarlato, F. C.; Santos, Milton et all. O novo mapa do mundo: globalização e espaço latino-americano. São Paulo, Hucitec, 2002, p. 34.

${ }^{92} \mathrm{O}$ que provocaria uma enorme concentração de investimentos estrangeiros diretos nos países mais desenvolvidos, provocando uma brutal concentração de capitais e rendas nos países centrais, de acordo com Sedi Hirano na obra acima citada.

${ }_{93}^{93}$ Garcia Canclini, Nestor, op. cit. , p. 85.

${ }^{94}$ Garcia Canclini, Nestor, op. cit. , p. 86.
} 
É contra esse projeto de arte de “experimentação formal aparentemente despolitizada” que Marta Traba vai defender uma vertente da produção de arte latino-americana como uma cultura da resistência.

De forma bastante perspicaz, ela observa que a questão da “existência cultural” está ligada “à recepção ou atenção que se dedique a determinadas invenções e sempre tem um sentido relativo: por exemplo, a escultura africana existe para a Europa quando Picasso a incorpora à sua pintura”95. Para Traba, o projeto da arte moderna e atual, processada em Paris e Nova York, "serviu incondicionalmente a um programa imperialista destinado a desqualificar as províncias culturais e a unificar os produtos artísticos num todo enganosamente homogêneo" ${ }^{\text {,96 }}$ objetivando a criação do que ela chamou de cultura planetária. Dentro dessa cultura planetária, "nossa existência artística sequer se [colocaria] como uma probabilidade»"97. Essa cultura planetária produzida pelas sociedades altamente industrializadas se moveria dentro de certos limites bem precisos: 1. da "produção incessante de arte de consumo; 2 . da liquidação do conceito da arte como ficção, tachandoa de anacronismo; e 3. da escalada do terrorismo das vanguardas” (grifos da autora). ${ }^{98}$ No âmbito das artes plásticas na América Latina, que já passaram pelo modernismo dos anos 20, também produto da influência das primeiras vanguardas históricas européias, a neo-vanguarda dos anos 50, que Traba nomeia indistintamente de vanguarda, representa a causa do "esvaziamento total da obra de arte”. Ao colocar-se a serviço daquela cultura planetária, “as vanguardas [teriam perdido] o poder de representar qualquer grupo humano, propondo, em troca, entretenimentos inócuos, estúpidos ou ferozes, mas sempre vazios, para satisfação das elites manipuladoras"99.

Diante desse estado da arte da metrópole, a exclusão dos artistas latino-americanos é encarada por Marta Traba nem como destruidora de sua existência nem como “desdouro”. Ao contrário, apontaria para uma linha coerente de trabalho que ela chama de cultura da resistência, cuja tradição, bem alicerçada, remontaria aos trabalhos de Torres Garcia, Reverón, Matta, passando por Szyszlo, Morales e Cuevas até chegar na geração mais

\footnotetext{
${ }^{95}$ Traba, Marta. A cultura da resistência, op. cit., p.20.

${ }^{96}$ Traba, Marta. A cultura da resistência, op. cit., p.20.

${ }^{97}$ Traba, Marta, op. cit., p.20.

98 Traba, Marta, op. cit., p.20.

99 Traba, Marta, op. cit., p.20.
} 
jovem, que teriam entre 20 e 30 anos no período dos anos 60-70, manifestamente mais enérgica com relação ao repúdio e à rejeição daquele projeto da cultura planetária.

Além do repúdio ao projeto, a característica comum aos artistas da resistência tem sido a disposição de formular a arte como linguagem, esclarecer suas possibilidades de comunicação e garanti-la com uma semiótica, pela qual a estrutura da obra só adquira seu valor ao ser interrogada e usada por um grupo humano ${ }^{100}$.

Nesse sentido, a "arte latino-americana da resistência existiria para nós, e cumpriria uma função epistemológica e um serviço público”. Seria uma arte polissêmica, sem acatar nenhum programa determinado que desemboque em "formas estatuídas de antemão”. A resistência seria assim antes de tudo um comportamento estético. Traba conclui seu raciocínio, afirmando que

a existência da arte latino-americana está ligada à nossa capacidade para sustentar nossos pontos de vista, à agilização de nossos argumentos, à modernização do caminho crítico e à conscientização de que a salvação dos marginais está em acentuar sua marginalidade e dotá-la de sentido.

Este "acentuar sua marginalidade" remete diretamente ao manifesto do cinema novo brasileiro, denominado estética da fome, expressão que a liga por associação à antropofagia do modernismo literário e plástico, brasileiro e latino-americano, dos anos 20 e 30. A marginalidade do cinema novo se justificaria pelo fato de o cinema industrial estar comprometido “...com a mentira e com a exploração”"101. Seu compromisso com a verdade, sua reflexão sobre a "fome latina", sobre sua impotência, sua "miserabilidade”, sua "histeria e esterilidade” foram todas tentativas de respostas tanto no discurso verbal do manifesto quanto no discurso fílmico das imagens na tela a questões como as que Glauber Rocha e outros integrantes do movimento se fizeram. A pertinência de tais questões continua tristemente vigente nos dias atuais:

1. Como o mundo subdesenvolvido pode desenvolver culturas que escapem das modernas formas de colonialismo?

2. E como essas culturas podem expressar, tanto aos "colonizados" como aos “colonizadores”, a realidade em que foram desenvolvidas?

\footnotetext{
100 Traba, Marta. A cultura da resistência, op. cit., p.21.

${ }^{101}$ Rocha, Glauber. “Uma Estética da fome”. In Arte em Revista, Ano 1, No. 1, Jan-Mar/1979, p. 15-17
} 
“A América Latina, inegavelmente, permanece colônia, e o que diferencia o colonialismo de ontem do atual é apenas a forma mais aprimorada do colonizador»102.

Nesse contexto de colônia,

a mendicância, tradição que se implantou com a redentora piedade colonialista, tem sido uma das causadoras de mistificação política e da ufanista mentira cultural: os relatórios oficiais da fome pedem dinheiro aos países colonialistas com o fito de construir escolas sem criar professores, de construir casas sem dar trabalho, de ensinar o ofício sem ensinar o analfabeto. (...) O comportamento exato de um faminto é a violência, e a violência de um faminto não é primitivismo. (...) Uma estética da violência antes de ser primitiva é revolucionária. (...) Essa violência, contudo, não está incorporada ao ódio, como também não diríamos que está ligada ao velho humanismo colonizador. $\mathrm{O}$ amor que esta violência encerra é tão brutal quanto a própria violência, porque não é um amor de complacência ou de contemplação, mas um amor de ação e transformação ${ }^{103}$.

O brasileiro não come e tem vergonha de dizer isto e, sobretudo, não sabe de onde vem esta fome; “....somente uma cultura da fome, minando suas próprias estruturas, pode superar-se qualitativamente: e a mais nobre manifestação cultural da fome é a violência”104.

O posicionamento e o discurso de Glauber, ainda mais contundentes que o de Traba, é mais um ato dentro do que Traba chamou de cultura da resistência, tornando visível os fios aparentemente invisíveis que ligam subjacentemente diversos artistas de modalidades distintas da arte no curso desse período de "grandes crises de consciência e de rebeldia, agitação e revolução que culminou no golpe de abril”"105, no Brasil, e em todos os golpes militares e ditatoriais que espalharam pela região em anos posteriores.

\section{As vanguardas históricas européias e russas}

No intervalo de tempo que abarca fins da década de 50 até fins da década de 70 do século XX, período em que o Nuevo Teatro surgiu, desenvolveu-se e atingiu o seu auge, podem ser detectadas em sua configuração múltiplas influências estéticas, sociais, políticas e filosóficas tanto no que concerne à sua estrutura formal quanto no âmbito do conteúdo, as quais retrocedem às suas raízes mais obscuras por um lado e, por outro, avançam na utópica

\footnotetext{
${ }^{102}$ Rocha, Glauber. “Uma Estética da fome”, op. cit., p.16.

${ }^{103}$ Rocha, Glauber. “Uma Estética da fome”, op. cit., p.17.

${ }^{104}$ Rocha, Glauber. “Uma Estética da fome”, op. cit., p.17.

${ }^{105}$ Rocha, Glauber. “Uma Estética da fome”, op. cit., p.17.
} 
construção do futuro, simultaneamente. Nesse intervalo de tempo, o nuevo teatro propiciou uma até então não vista experiência, qual seja, a de forçar e empurrar as portas pesadas do tempo para trás e para frente, num processo de ampliação e dilatação temporal como dispositivo de auto-conhecimento, seguindo à risca o princípio segundo o qual para se conhecer o presente, projetar o futuro, há que se conhecer o passado. Assim, para elaborar a vida de um futuro possível, apropriar-se do passado mais passado quanto do passado mais recente se torna uma exigência. E, assim apropriam-se tanto das formas teatrais précolombianas quanto das vanguardas artísticas européia e norte-americanas. Ainda que o aporte de cada uma delas tenha sua própria especificidade, tamanho, peso e medida distintos, todas desempenharam um papel fundamental na formulação da imagem poética teatral latino-americana.

A abordagem do Nuevo Teatro como sendo um fenômeno da vanguarda teatral na Colômbia e na América Latina já é uma idéia recorrente em muitos estudiosos; o que ainda não se costuma encontrar são estudos que mostrem de que forma se dá essa vanguarda latino-americana, ou seja, de que modo ela surge nos elementos constitutivos das obras. E como esses elementos vanguardistas se convertem enfim naqueles elementos constitutivos da imagem poética da América Latina, ou, no que se pode dizer, na "latinoamericanidad” dessa imagem poética.

\section{As vanguardas artísticas européias}

Os movimentos de vanguarda representam o ponto lógico na evolução da arte na sociedade burguesa ${ }^{106}$. A partir desta proposição, Peter Bürger desenvolve sua teoria da vanguarda como categoria de análise capaz de explicar de forma cabal tanto a radicalidade quanto a "novidade", experiências sem precedentes na história da arte mundial, representadas pelas vanguardas artísticas européias. Até então, tratadas, pelos muitos estudiosos que se debruçaram sobre o assunto, como categorias históricas, a proposta teórica de Bürger surge como estudo de ponta na continuidade da vertente da crítica cultural marxista, iniciada e aprofundada pelos filósofos-pensadores da escola de Frankfurt.

\footnotetext{
${ }^{106}$ BÜRGER, P. Teoria da Vanguarda. Lisboa: Vega, 1993, p.17.
} 
Como este trabalho se apropria da teoria da vanguarda de PB para compreender o processo de formação da imagem poética do Nuevo Teatro, faz-se mister descrição sucinta do movimento de vanguarda, entendida em seu significado histórico, para cuja abordagem, vale a pena perguntar como Ferreira Gullar: “como surge o fenômeno dos 'movimentos artísticos' de intenso dinamismo renovador? Qual a origem dessa tendência à 'ação coletiva' que, a partir do Romantismo, irrompe na história da arte?" ${ }^{107}$. "Conhecer a origem, as características e o desenvolvimento” deste fenômeno que "abalou as estruturas das artes, (...) facilita a compreensão do movimento local” ${ }^{\text {"108 }}$.

Para isso, evoque-se a Europa do século XVIII, período em que ocorreram três grandes revoluções: econômica, política e mental, as quais representariam o marco da instauração do que ficou conhecido como "modernidade européia". Tratam-se da Revolução Industrial na Inglaterra(17), da Revolução Francesa (1789) e da Revolução das Idéias na Alemanha (Kant) ${ }^{109}$. Com relação ao pensamento científico, a contribuição destes mesmos países pode ser resumida respectivamente em conceitos como o empirismo (inglês), o racionalismo (francês) e o idealismo (alemão). É o tempo de nascimentos de ciências e escolas científicas. É o tempo de "nascimentos” dos Estados e das nações, junto com nascimento dos próprios conceitos de “nação”, “povo”, “democracia”, “civilização e cultura”, e "estética”. Determinações externas múltiplas, revolucionárias, em todos os aspectos do mundo da vida, convergiriam no transcorrer dos últimos três séculos para formar o “caldo” cultural, em cujo processo, a um só tempo brutal e contraditório, se gestaria o “modo moderno” de percepção e consideração da obra de arte e da estética, cuja culminação e rotura iriam explodir nos movimentos de vanguarda das três primeiras décadas do século XX.

Sobre a estética, não se pretende entrar no debate filosófico sobre sua origens e problemas, mas pode ser revelador ter em conta a observação de Terry Eagleton (1993, p.7 e segs.) sobre a importância atribuída a ela na História da Filosofia européia desde o Iluminismo: Kant, Hegel, Kierkegaard, Schopenhauer e Nietzsche, Marx e Freud,

\footnotetext{
${ }^{107}$ FERREIRA GULLAR. Vanguarda e subdesenvolvimento. Rio de Janeiro: Civilização Brasileira, 1969, p.14.

${ }^{108}$ BOAVENTURA, Maria Eugênia. A vaguarda antropofágica. São Paulo: Ática, 1985, p.14.

${ }^{109}$ Como se tratam de marcos históricos amplamente estudados e relativamente sabido de todos, não se deterá aqui em desenvolvê-los. São citados apenas como referências cruciais dos processos de profundas transformações por que passaram as sociedades européias do período.
} 
Heidegger, Lukács e Adorno, todos dotaram-na de um espaço considerável em seus sistemas de pensamento. O que leva Eagleton a se perguntar, por sua vez, o porque dessa persistência, o por que dessa tenacidade "teórica do estético" - [qualificando] um período histórico em que a pratica cultural mostra-se destituída de sua relevância social tradicional, rebaixada mesmo a um ramo da produção generalizada de mercadorias”, ao que ele irá responder, segundo sua própria percepção, dever-se “ao contexto rarefeito da natureza cada vez mais abstrata e técnica do moderno pensamento europeu”, no qual apenas a arte ainda “poderia falar do humano e do concreto", permitindo-nos um descanso bem vindo frente “aos rigores alienantes dos outros discursos mais especializados, e oferecendo, no coração mesmo desta grande explosão e fragmentação dos saberes, um mundo residualmente comum"110.

A arte poderia "falar do humano e do concreto" desde que articulada na práxis vital da sociedade, tornando-se então este o eixo, em torno do qual vertentes mais radicais dos movimentos de vanguarda centrariam suas críticas e reivindicações. De acordo com a análise de Peter Bürger, “a intenção dos vanguardistas pode definir-se como sendo a tentativa de devolver a experiência estética (oposta à praxis vital), criada pelo esteticismo, à prática”"111. Curioso observar ainda que talvez possa haver algum sentido na ruptura que parece ocorrer na passagem do uso do termo "estética” para a adoção do uso de “cultura” como categoria de análise. Parece ter havido uma espécie de deslocamento, provocado pela saturação do uso de "estética” como categoria teórica até o auge da vanguarda (1930), para a apropriação e preferência posteriores do termo “cultura” como nova categoria. Eagleton sugere isso ao indicar que nos "debates contemporâneos sobre a modernidade, o modernismo e o pós-modernismo, a ‘cultura’ parece ser a categoria-chave para a análise e a compreensão da sociedade capitalista tardia"112. O que esse dado poderia significar ao ser transposto para a análise da sociedade contemporânea?

A partir das revoluções perpetradas no curso do século XVIII, da revolução burguesa, do sistema capitalista em consolidação, da constituição moderna das cidades, da idéia de mercado, de produto, do processo progressivo de racionalização da vida moderna,

\footnotetext{
${ }^{110}$ EAGLETON, Terry. A ideologia da Estética. Rio de Janeiro, Zahar, 1993, p 7 e seguintes.

111 BÜRGER, Peter. Op. cit., p.66.

${ }^{112}$ EAGLETON, Terry. Op. cit., p.7.
} 
tem-se início um modo de vida nunca dantes imaginado. Neste contexto de mudanças radicais, a vida intelectual e artística, desde a Idade Média e Renascimento subjugada pela tutela da aristocracia e da Igreja, dão, pela primeira vez na história, uma guinada radical, expressa no processo paulatino de sua libertação dos jugos econômicos, sociais, éticos e estéticos. Pierre Bourdieu descreve claramente como se sucedeu o processo de autonomização da esfera da arte nas sociedades européias, como "as transformações da função do sistema de produção de bens simbólicos e da própria estrutura destes bens” foram correlatas “à constituição progressiva de um campo intelectual e artístico, ou seja, à autonomização progressiva do sistema de relações de produção, circulação e consumo de bens simbólicos»" ${ }^{113}$. Em oposição à esfera econômica, à esfera política e religiosa, a esfera da arte vai se definindo progressivamente ao reivindicar o direito de "legislarem em seu próprio campo - o campo da forma e do estilo - ignorando exigências externas” de demandas sociais, políticas e religiosas. Bourdieu aponta a Florença do século XV como o primeiro momento de reivindicação e afirmação de uma legitimidade propriamente artística, interrompida por durante quase dois séculos pela monarquia absoluta e pela contra-Reforma ${ }^{114}$.

A partir do século XVIII, esse processo de “autonomização” se dá em meio a uma série de outras transformações, dentre as principais descritas por Bourdieu, estão:

1. a constituição de um público consumidor virtual crescente, que se constituiria também em instância legitimadora;

2. a constituição de um campo, cuja profissionalização diferenciada de mediadores, compostos de produtores e empresários, impõe imperativos técnicos que definem o acesso à profissão e o acesso ao meio;

3. a multiplicação e a diversificação das instâncias de consagração artística, competindo pela legitimidade cultural, como por exemplo, as academias, os salões (onde, sobretudo no século XVIII, com a dissolução da corte e da arte cortesã, a aristocracia mistura-se com a intelligentsia burguesa e passa a adotar seus modelos de pensamento e suas concepções artísticas e morais);

4. a multiplicação e diversificação das instâncias de difusão cujas operações de seleção são investidas por uma legitimidade propriamente cultural, ainda que, como no caso das editoras e das direções artísticas dos teatros, continuem subordinadas a obrigações econômicas e sociais capazes de influir, por seu intermédio, sobre a

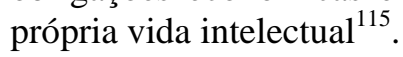

\footnotetext{
113 Bourdieu, Pierre. A economia das trocas simbólicas. São Paulo, Perspectiva, 2004, p.99.

114 Bourdieu, P. 2004, p.101.

115 Sobre o processo de autonomização da produção literária e artística, a formação paralela de um campo artístico, constituído por distintos agentes, cujas mediações articulavam e impulsionavam a circulação dos bens simbólicos na sociedade européia de massa em formação, ver especialmente as obras do sociólogo
} 
Todas essas transformações ligadas ao processo de autonomização do campo artístico são aceleradas "brutalmente com a Revolução Industrial e com a reação romântica” (Bourdieu, p.103). O modo de vida burguês se consolida, baseado nos pressupostos apregoados pelo Iluminisno, com a ratio humana como medida de todas as coisas; com o empreendedorismo capitalista subjugando a natureza e tudo o que ela representa; com a objetividade e o utilitarismo orientando a vida prática. "Destituída dos ideais da revolução” e de qualquer idealismo, “os valores da burguesia gloriosa são o lucro, a avareza e a eficácia”116, o que explica a dimensão da brutalidade presente na primeira fase da revolução industrial inglesa, a qual gerou por sua vez, sob este argumento do lucro máximo e da máxima produtividade, uma massa de famintos, desvalidos e "homens livres" - no sentido de "estarem desprovidos de qualquer propriedade e desligados da autoridade de um senhor; prontos, portanto, a se tornarem mão de obra industrial”"117. Nessa situação de precariedade da vida, a única possibilidade era a mudança para os centros “urbanos”: as cidades ainda em formação, onde iriam constituir os operários das fábricas então nascentes, dando origem assim à figura do proletário: o trabalhador assalariado.

O Romantismo nasce como uma reação à brutalidade da vida imposta pela industrialização e à mediocridade da vida burguesa. Como fuga do presente, refugia-se num passado em que seus valores se realizavam sem antagonismo entre idéia e realidade, pessoa e mundo, indivíduo e sociedade, como diz a reflexão de Ferreira Gullar:

o artista romântico inicia, assim, a batalha contra tudo o que define a objetividade burguesa e a vida prática, terminando por afirmar que 'o fluxo dos pensamentos e sentimentos é mais real que a realidade exterior'. Em contraposição à cautela e à mesquinhez burguesas, o romântico faz profissão de fé da audácia e do desprendimento, da vagabundagem, do sonho, de tudo o que se opõe à vida cinzenta do cotidiano ${ }^{118}$.

francês, Pierre Bourdieu, tais como, A Regra da arte ( 2003); A economia das trocas simbólicas (1993). Nesta última, encontra-se, por exemplo, explicitado o paradoxo que acompanha esse processo: "no momento em que se constitui um mercado da obra de arte, os escritores e artistas têm a possibilidade de afirmar - por via de um paradoxo aparente - ao mesmo tempo, em suas práticas e nas representações que possuem de sua prática, a irredutibilidade da obra da arte ao estatuto de simples mercadoria, e também, a singularidade da condição intelectual e artística. In: Bourdieu, Pierre. A economia das trocas simbólicas, 2004,p.103.

${ }^{116}$ Gullar, Ferreira, 1969, p.15.

${ }^{117}$ COULON, Olga Maria A. Fonseca; Pedro, Fábio Costa. "Dos Estados Nacionais à Primeira Guerra Mundial”, 1995, CP1-UFMG. Site: http://www.hystoria.hpg.ig.com.br/rindus01.html; Acesso em 10/07/2006.

${ }^{118}$ GULLAR, FERREIRA. Op. cit., p.15. 
É nesse momento que iria se estabelecer "o abismo entre o gênio e o homem vulgar, entre a arte e a realidade social”. As conseqüências que essa “cisão” iria provocar na arte seriam irreversíveis. Até os dias atuais prevalecem idéias como a da "inspiração" como sendo privilégio de artistas talentosos em oposição à da arte como trabalho, reflexão e “transpiração"; ou a da idéia de gênio em oposição aos "pobres mortais”. Ainda que num momento imediatamente posterior tenham surgido movimentos como o da chamada "arte social” capitaneada por Champfleury de um lado; e, da “arte pela arte”, encabeçada por Flaubert, de outro. Se a arte realista reivindicada por Champfleury pressupunha a descrição objetiva da realidade social, retratando personagens até então extirpados dos temas literários, o realismo de Flaubert, diferentemente não "descrevia” mas “escrevia” o real. Champfleury queria "uma literatura de pura observação, social, popular, que excluísse toda a erudição"119, em que o estilo fosse considerado como uma propriedade secundária. Representou de certo modo um recuo em relação ao “abismo romântico”, uma vez que não se tratava, neste caso, de um gênio inspirado, mas de um bom retratista. Diferentemente, Flaubert, cuja obra é considerada “inclassificável”, opõe-se tanto à arte pela arte quanto aos realistas. Bourdieu comenta sobre os “debates insolúveis” que ele suscitou “entre aqueles que querem puxá-lo para o realismo e aqueles que, mais recentemente, quiseram anexá-lo ao formalismo ${ }^{120}$. Bourdieu propõe uma conciliação para forjar uma vertente que dê conta do programa estético de Flaubert, que ele chama de formalismo realista ${ }^{121}$. A produção literária de Flaubert concentrando e tentando solucionar todos os problemas estéticos do campo artístico em construção, impostos pela sua época, pode ser resumida em seu programa estético expresso na “fórmula”: “escrever bem o medíocre”. Ela constitui uma vertente, ao contrário do realismo do grupo de Champfleury, que se distancia ainda mais do "povo" e reforça o "abismo” inagurado pelo movimento romântico.

\footnotetext{
${ }^{119}$ Bourdieu, Pierre. As regras da arte. São Paulo: Companhia das Letras, 1996, p.111.

${ }^{120}$ Bourdieu, P., 1996, p.112.

${ }^{121}$ Boudieu primeiro se apropria do dito do poeta Baudelaire, segundo o qual, "há na palavra, no verbo, algo de sagrado que nos impede de fazer dele um jogo de azar. Manipular habilmente uma língua é praticar uma espécie de feitiçaria evocatória”( Baudelaire, Oeuvres completes, t. II, pp.112-3) apud Bourdieu (1996, p.127). Parece-me que não é induzir o sentido da última frase ver aí o programa de uma estética fundada na conciliação de possíveis indevidamente separados pela representação dominante da arte: um formalismo realista.[Grifo do autor] (Bourdieu, 1996, p.127).
} 
É justo mencionar num salto ao século XX que a despeito do fracasso do projeto vanguardista dos primeiros trinta anos, a neo-vanguarda dos anos 50 promoveu e reforçou paradoxlamente ao objetivo das primeiras vanguardas o ampliamento da separação entre arte e vida, com vertentes como a da arte conceitual, abstrata etc.; além de resultar numa multiplicidade de movimentos e escolas, cujas contradição e ambigüidade seriam suas marcas. Se no movimento romântico é possível detectar o momento seminal desse “abismo” entre arte e a vida, num segundo desdobramento desse impulso, com a maior especialização da esfera da arte, detecta-se um “abismo” - em segundo grau -, uma vez que não se trata mais do abismo entre arte e vida, mas de um abismo muito maior entre a “abstração da arte” e a vida. Para entender melhor a subdivisão interna da arte, cindida de um lado, pela abstração pura (ou teoria) e, de outro, pela concretude da obra do artista, nada como recorrer mais uma vez à clareza da exposição de Bourdieu:

...o processo de diferenciação das esferas da atividade humana correlato ao desenvolvimento do capitalismo e, em particular, a constituição de sistemas de fatos dotados de uma independência relativa e regidos por leis próprias, produzem as condições favoráveis à construção de sistemas ideológicos, vale dizer, as chamadas teorias "puras" (da economia, da política, do direito, da arte etc) que reproduzem as divisões prévias da estrutura social com base na abstração inicial através da qual elas se constituem. De acordo com a mesma lógica, tudo leva a crer que a constituição da obra de arte como mercadoria e a aparição, devido aos progressos da divisão do trabalho, de uma categoria particular de produtores de bens simbólicos especificamente destinados ao mercado, propiciaram condições favoráveis a uma teoria pura da arte - da arte enquanto tal -, instaurando uma dissociação entre a arte como simples mercadoria e a arte como pura significação, cisão produzida por uma intenção meramente simbólica e destinada à apropriação simbólica, isto é, a fruição desinteressada e irredutível à mera posse material ${ }^{122}$.

Ao se confrontar e criticar os valores do modo de vida burguês e o sistema econômico capitalista, evocando em oposição os valores da tradição, o movimento romântico promove por outro lado tanto a já referida cisão entre arte e vida quanto a “ilusão" de autonomização da arte, contribuindo para o processo de institucionalização da arte, que representa em última análise a completa apropriação da arte pelo sistema capitalista, ou, visto de outro modo, a completa acomodação da arte aos mecanismos de mercado, proposto pelo capitalismo, tornando-se mercadoria como qualquer outra.

\footnotetext{
${ }^{122}$ BOURDIEU, Pierre, 2004, p.103.
} 
“Ilusão de autonomia” por que, como mostra também Bourdieu, a tal "liberdade” do artista propiciada pela sua libertação dos jugos econômicos, políticos e religiosos, logo se revelará formal, "sendo apenas a condição de sua submissão às leis do mercado de bens simbólicos, vale dizer, a uma demanda que, feita sempre com atraso em relação à oferta, surge através dos índices de venda e das pressões, explícitas ou difusas, dos detentores dos instrumentos de difusão, editores, diretores de teatro, marchands de quadros”123.

De certa forma, se o romantismo representa, por um lado, um momento de politização da arte e da criação de artistas partidários, de facções e escolas concorrentes etc; por outro, ele pode também ser entendido como o impulso inicial da crítica da arte burguesa que só poderia desembocar no radicalismo das reivindicações vanguardistas, entendidas estas como o momento da própria autocrítica da arte na sociedade burguesa e capitalista, como assim revelou a reflexão de Peter Bürger.

\section{Origens e usos do termo vanguarda}

Que o termo "vanguarda” se trata de um termo militar em sua origem é um dado sabido de todos. Em sua primeira acepção, como encontrada em qualquer dicionário, a referência ao exército é clara. Segundo o Aurélio, o termo vem do francês avant-garde:

1. Exérc.: Extremidade dianteira de unidade ou subunidade em campanha. 2. Frente, testa, dianteira. [Antôn., nessas acepç.: retaguarda.] 3. A parcela mais consciente e combativa, ou de idéias mais avançadas, de qualquer grupo social. 4. P. ext.: Grupo de indivíduos que, por seus conhecimentos ou por uma tendência natural, exerce papel de precursor ou pioneiro em determinado movimento cultural, artístico, científico,etc.: A vanguarda intelectual brasileira tomou parte na Semana de Arte Moderna, em 1922. [Sin. ger., p. us.: anteguarda.]

O que ainda é um fato não muito claro é a passagem do termo para significações mais amplas. Recorrer a um pequeno resumo da evolução histórica do termo pode ser revelador do quanto o uso truncado e ilimitado do termo foi sujeito a mal-entendimentos.

\footnotetext{
${ }^{123}$ BOURDIEU, Pierre. Op. cit., p.104.
} 
Serão utilizadas as análises de duas obras: A vanguarda Antropofágica ${ }^{124}$, de Maria Eugênia Boaventura; e Vanguardas Latino-Americanas: polêmicas, manifestos e textos $\operatorname{críticos}^{125}$, de Jorge Schwartz. Evidentemente existe uma literatura ampla sobre o tema ${ }^{126}$, mas, para o interesse desse trabalho, identificar sua localização histórica é suficiente, sob o risco de desnecessária extrapolação do tema.

"Inicialmente restrito ao vocabulário militar do século XIX",127, o termo "vanguarda acaba migrando para o âmbito da arte e da política. Conta Jorge Schwartz que foi entre os discípulos de Saint-Simon (1760-1825) que o termo vanguarda acabou adquirindo na França um sentido figurado na área política. Saint-Simon, um dos fundadores do socialismo utópico, como indica Schwartz, costumava afirmar que “o papel da vanguarda artística, na medida em que pretende revolucionar a sociedade, [revestir-se-ia] de uma função pragmática e de uma finalidade social”, ou seja, a arte "deveria se dedicar a atingir fins sociais e daí ser necessariamente funcional, utilitária, didática e facilmente compreensível”128. Maria Eugênia Boaventura, a partir da leitura da obra de Matei Calinescu, completa a informação de Schwartz, precisando a data de emprego do termo “vanguarda” à arte, o que teria acontecido em 1825. E se refere a outra figura importante neste cenário: a personalidade do filósofo e economista francês Charles Fourier (17721837), sugerindo que os dois franceses (Simon e Fourier) encaravam "a arte como missão reveladora e precursora”129 - sem deixar claro que se de forma coincidente ou não. Já Schwartz afirma a oposição entre ambos. Segundo sua leitura, contrário à postura de SaintSimon, Fourier defenderia a dissociação da arte de um sentido político. Deste modo e se Schwartz estiver certo, já no primeiro quartel do século XIX, o cenário do debate entre

\footnotetext{
124 São Paulo: Ática, 1985.

${ }^{125}$ São Paulo: Editora da Universidade de São Paulo: Iluminuras: FAPESP, 1995.

${ }^{126}$ Em nota de rodapé, o próprio Jorge Schwartz indica “os melhores estudos sobre a evolução do conceito de vanguarda”(p.34), a saber, EGBERT, Donald Drew. “The Idea of Avant-Garde’ in Art and Politics”; e, CALINESCU, Matei. Five Faces of Modernity. E Maria Eugênia Boaventura reproduz na introdução de sua obra parte do debate em torno do termo nos anos 70, cotejando artigos de vários estudiosos como Zdenko Skreb, Miklós Szabolcsi, Henri Lefèbvre, Loius Aragon, Ulrich Weisstein, Guillaume Apollinaire, Tristan Tzara, Renato Poggioli entre outros.

${ }^{127}$ SCHWARTZ, Jorge, 1995, p.35.

${ }^{128}$ Egbert, Donald D. “The Idea of Avant-Garde” in Art and Politics”. In: The American Historical Review 73, no. 2 (dez.1967), pp 339-366. Apud (Schwartz, 1995, p.34).

${ }^{129}$ BOAVENTURA, Maria Eugênia. Op. cit., p.6.
} 
“arte engajada” (Simon) e a "arte pela arte” (Fourier) estaria dado, debate que se prolongaria ao longo do século XX.

Ainda seguindo as trilhas de Schwartz, fica-se sabendo que embora Marx e Engels, fundadores do comunismo, fizessem uso do termo por se considerarem parte da vanguarda social, é Lênin quem faria um uso estritamente político do termo, ao citar os autores acima em seus discursos. Segundo Lênin, "ao educar os trabalhadores do partido, o marxismo educa a vanguarda do proletariado”"130. Nesse momento, começa a se espalhar “a partir de 1890 na Europa inúmeros jornais politicamente partidários, comunistas, socialistas e anarquistas, que trazem no título a palavra 'vanguarda”,131. Já com relação ao uso do termo para se referir às idéias estéticas, Boaventura indica a data de 1870, momento em que tem início as revoltas “contra a tradição” ${ }^{132}$, mas já com a palavra impregnada de forte conotação política. “A tensão do confronto entre 'vanguarda política' e 'vanguarda artística’ resulta em diversas influências na produção cultural dos anos 20, que variam de acordo com o momento, os contextos e as experiências individuais dos fundadores dos movimetnos" ${ }^{\prime 33}$.

"Pouco interessa se a palavra vanguarda - nas discussões, manifestos e programas dos diversos movimentos artísticos do início do século - não é empregada fartamente de maneira explícita. O importante é que a crítica tenha conseguido um termo para agrupar o grande arsenal de manifestações heterogêneas" ${ }^{\text {"34 }}$.

Noutra parte, Schwartz afirma que “o surgimento dos ismos europeus dá grande margem à experimentação artística, desvinculada, em maior ou menor grau, de pragmatismos sociais”135. Ou seja,

embora as vanguardas artísticas tenham por denominador comum a oposição aos valores do passado e aos cânones artísticos estabelecidos pela burguesia do século XIX e início do XX, elas se distinguem entre si não apenas pelas diferenças formais e pelas regras de composição, mas por seu posicionamento frente às questões sociais.

Nesse sentido, o expressionismo alemão e o surrealismo francês, situados respectivamente no início e no fim do período das vanguardas, embora

\footnotetext{
${ }^{130}$ Lênin cita O manifesto comunista de Karl Marx.

${ }^{131}$ SCHWARTZ, Jorge. Op. cit., p.35.

${ }^{132}$ BOAVENTURA, Maria Eugênia. Op. cit., ibidem.

${ }^{133}$ Schwartz, J. 1995, p.36.

${ }^{134}$ Boaventura, M.E., 1985, p.7.

135 Schwartz J., 1995, p.35.
} 
tão diferenciados em outros aspectos, têm como denominador comum a preocupação social. Porém, enquanto o expressionismo é uma reação aos horrores da Primeira Guerra, o surrealismo aponta para a utoia da rtansformação do homem através da liberação das forças do inconsciente. (...) por outra parte, o futurismo sai na dianteira de todos os ismos como violenta reação contra a burguesia da época, contra a arte musológica, contra qualquer parâmetro passadista. A tentativa de abolição do tempo e da distância aproxima o futurismo italiano do simultaneísmo e do multiperspectivismo propostos pelos cubistas da década de 10 . já o dadaísmo, também uma reação à Primeira Guerra, atua de maneira diferente: pelo niilismo, pelo humor, pela auto-irrisão e pela autodestruição ${ }^{136}$.

\section{Tentativas de definição}

Boaventura reconstrói parte do debate que girou em torno da definição do termo nos anos 70 dentro do âmbito da literatura, o que também ajuda a compreender a evolução do conceito. Algumas conclusões podem ser tiradas a partir disso, como a de que, até meados da década de 80 do século XX, a crítica de orientação marxista e de esquerda recusa o fenômeno das vanguardas como um movimento revolucionário, mas apenas como expressão da decadência da arte burguesa, ilustrada principalmente na figura de Lukács. De qualquer modo, Gramsci, Artatov e Trostky reconhecem algumas ações tipicamente revolucionárias “perdidas” dentro da ambigüidade do movimento; de modo que os três detectam nos Futurismos italiano e russo pontos de contatos como a "capacidade de percepção da realidade capitalista (...), e ação subversiva como a da tentativa de democratização da arte”, enfim, consideram-no um fenômeno progressista ${ }^{137}$.

Ela identifica também uma outra parcela da crítica acadêmica que estuda a Vanguarda como um “aspecto da Modernidade” (...), ou "sob um ângulo psicologizante” (Poggioli: 1962)) (Skreb: 1974)); como análise histórica (Marino:1976, 1977) ou como um conjunto de vários aspectos (Kibédi Varga: 1975); e, enfim, “Kramer, Noszólopy, Skreb e Szabolcsi identificam-se na conceituação de Vanguarda como um dado histórico, fruto de uma época determinada”138(p.10).

\footnotetext{
${ }^{136}$ Schwartz J., 1995, p.35.

${ }^{137}$ Boaventura, M. E., 1985, pp.8-9.

138 Boaventura, M. E., 1985, p.10.
} 
Outro conjunto importante de teóricos e críticos da vanguarda gira em torno do “Gruppo 63” italiano, que detecta na origem do movimento “conotações de ordem política e sócio-econômica, explicando-a não só em termos estéticos, mas relacionando-a com a

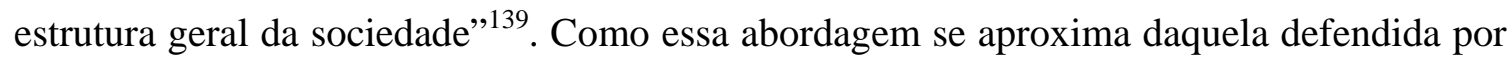
Bürger, vale a pena uma explicitação mais detalhada de suas formulações, resumidas na citação de Boaventura sobre o grupo que considera a Vanguarda como “...a resposta do artista às condições da sociedade e à sua situação profissional”140.

O nexo histórico entre Vanguarda e mercadoria permite a Edoardo Sanguineti defini-la, desde o início, como forma de contestação ao capitalismo (Vanguarda Histórica) e ao neoliberalismo (Neovanguarda). Em conseqüência, a situação histórica força o artista a atuar criticamente perante a arte e a sociedade. (...) [Estuda-se] a Vanguarda como um movimento polêmico e de ruptura em relação ao passado, composto de dois momentos inseparáveis: a instituição do novo e a descoberta de meios expressivos novos ${ }^{141}$.

O debate sobre o significado da vanguarda literária continua e avança, de modo que na mesma década de 70, chega-se a uma compreensão muito mais complexa do fenômeno, como deixa transparecer o quadro construído por Boaventura, no qual acrescenta a contribuição da reflexão de Ferrucio Mansini (1973), segundo a qual, a vanguarda, ao perceber "a necessidade de aliar sua produção artística aos movimentos de transformação da sociedade" ${ }^{142}$, põe a descoberto seus elementos de ruptura ideológicos. A revolta geral e contraditória contra o mundo burguês seria a marca da Vanguarda: na literatura, nas artes plásticas, no teatro.

Outro aspecto do movimento vanguardista europeu é a sua tentativa de ser um movimento internacional, apenas a título de ilustração, cite-se o caso bastante referido nos trabalhos acadêmicos, “a peculiaridade do movimento Dada, surgindo quase que simultaneamente em vários centros artísticos (Zurique, Berlim, Paris)”143. Segundo trechos do manifesto, assinado por R. Huelsenbeck, lê-se por exemplo “a palavra Dadá demonstra a internacionalidade do movimento que não está ligado a nenhuma fronteira religiosa ou

\footnotetext{
${ }^{139}$ Boaventura, M. E., 1985, p.10.

${ }^{140}$ Boaventura, M. E., 1985, p.10.

${ }^{141}$ Boaventura, M. E., 1985, p.10.

142 Boaventura, M. E., 1985, pp.12-14.

143 Boaventura, M. E., 1985, p.15.
} 
profissional. Dada é a expressão internacional do nosso tempo, a grande fronde de movimentos artísticos, o reflexo artístico de todas estas diversas ofensivas” ${ }^{144}$.

Há certo consenso acadêmico com relação à demarcação temporal no qual se desenrola o movimento, o qual se sucederia entre 1905 e 1930, ou seja, no transcorrer das três primeiras décadas do século XX. Entretanto, é possível concluir que, embora as vanguardas históricas e artísticas européias tenham acelerado seu desenvolvimento neste período inicial do século $\mathrm{XX}$, suas raízes mais distantes remontam mesmo à primeira ruptura radical da visão de mundo, efetuada pelo o advento da própria Idade Moderna $^{145}$, e na seqüência em seu desdobramento na instauração da Modernidade ${ }^{146}$, cuja revolução do pensamento na filosofia é acompanhada, nas artes, do surgimento do movimento romântico, Sturm und Drang, Tempestade e Ímpeto. Esse movimento já traria dentro de si parte dos elementos seminais que explodiriam nas vanguardas: a mesma reação contra o capitalismo e o modo de vida burguês, a mesma ambigüidade latente num jogo de aproximação e distanciamento das outras esferas da vida. O que distingue as vanguardas é, sobretudo, além do alcance de sua contestação radical da "instituição arte”, o fato de que, depois dela, jamais a percepção da obra de arte seria a mesma.

\section{Os “ismos" das vanguardas}

Para se permanecer dentro do quadro temporal de 1905-1930, avalia-se que o evento considerado o marco do início do movimento tenha sido a repercussão das duas exposições dos "fauvistas"147 no Salão de Outono e no Salão dos Independentes, em 1905. Nesta última, a obra Luxe, Calme et Volupté de Matisse causou grande agitação ${ }^{148}$. Embora

\footnotetext{
${ }^{144}$ Boaventura, M. E., 1985, p. 15.

${ }^{145}$ Caracterizada entre outras coisas pelo início do ciclo das grandes navegações e dos "descobrimentos”, pelo estágio inicial do capitalismo mercantil, expansionista e de acumulação. Nas artes, pelo Barroco, Renascimento, Reforma e Contra-Reforma, abrangendo os séculos XV, XVI e XVII.

${ }^{146}$ Caracterizada pelo ciclo das revoluções: Francesa, Industrial e Filosófica. Pelo início das guerras de independência: Guerra de Independência dos Estados Unidos. Pelos inventos: máquina a vapor. Na arte: Classicismo e Iluminismo e Romantismo.

${ }^{147}$ Cabe lembrar que a pintura de Cézanne (XIX) foi considerada precursora do fauvismo e cubismo do início do século XX.

${ }^{148}$ Whitfield, Sara. “Fauvismo”. In.: Conceitos da arte moderna. Editor Nikos Stangos. Rio de Janeiro: Jorge Zahar, 2000, p.16. A propósito, as citações e aspas presentes no corpo do texto a seguir, referem-se a esta obra, coletânea que reúne ensaios sobre os principais conceitos e transformações da arte do século XX.
} 
“escândalos” começassem a ser uma constante nos salões de arte há algum tempo - pensese por exemplo na obra, entre outras, Bom dia, senhor Courbet, de 1854, do "realista" Gustave Courbet ${ }^{149}$; ou da Olympia, de 1863, do impressionista Edouard Manet ${ }^{150}$, entre outros de imensa lista - o radicalismo “das feras” - Henri Matisse, André Derain, Maurice Vlaminck - fizeram deles o grupo mais experimental de pintores no período, “uma espécie de”, nas palavras de Apollinaire, “ introdução ao cubismo”"151. A herança de certa atitude liberal e independente influenciada pelo mestre simbolista Gustave Moreau, ajudam-nos a negar a existência de qualquer doutrina ou princípio, tornando-se o mais transitório e menos indefinível dos movimentos. Costuma-se afirmar que o fauvismo pertencia tanto ao século XIX quanto ao XX, característica tornada evidente quando contraposta à Picasso: “...tendemos a avaliar a importância dessa tela [Joie de Vivre] através de Demoiselles d'Avignon de Picasso, pintada no ano seguinte [1907] e que parece desafiar diretamente tudo o que Matisse já tinha feito" 152 . E Sarah continua, concluindo que “a tela de Picasso nos torna conscientes de uma característica de Matisse, a sua afinidade com a tradição literária das décadas de 1880 e 1890”153.

1905 é o ano que marca o início de outra escola de vanguarda importante que, sem constituir num movimento, recebe o rótulo ${ }^{154}$ de "expressionista”, em virtude de uma parcela da produção artística pretender "impressionar-nos através de gestos visuais que transmitem, e talvez libertem, emoções ou mensagens emocionalmente carregadas”"155.

O Expressionismo está principalmente associado a dois grupos informais de artistas: o grupo Die Brücke (A Ponte), de Dresden, formado em 1905 e dissolvido em 1913, e os artistas de Munique que expunham sob a égide de um almanaque intitulado Der Blaue

\footnotetext{
149 “...causou alvoroço quando o quadro foi exibido na Exposição Internacional de Paris em 1855”. In: O livro da arte. São Paulo, Martins Fontes, 1999, p.111.

${ }^{150}$ Que já havia escandalizado críticos e público com sua obra anterior Déjeuner sur l’herbe. In: O livro da arte. Op. cit., p.296.

${ }^{151}$ Apud Whitfield, Sarah, 2000, p.11.

${ }^{152}$ Whitfield, Sarah, 2000, p.19.

${ }^{153}$ Whitfield, Sarah, 2000, p.19.

${ }^{154}$ O próprio rótulo veio muito tarde - em 1911, quando a exposição da Secessão de Berlim incluiu uma galeria de trabalhos designados como sendo da autoria de Expressionisten - todos eles de Paris: Matisse e os fauves, mais Picasso em sua fase pré-cubista. Em 1914, o rótulo foi aplicado aos artistas do Die Brücke e a outros. A idéia era aplicar este rótulo a todas as correntes internacionais surgidas depois do impressionismo e que se pensava serem anti-impressionistas. In: LYNTON, Norbert. “Expressionismo”.In: Conceitos da arte moderna. Op. cit., p.27.

${ }^{155}$ Lynton, Norbert. “Expressionismo”.In: Conceitos da arte moderna, 2000, p.24.
} 
Reiter (o Cavaleiro Azul), do qual só veio a ser publicado um único número em 1912. Outros artistas são geralmente agrupados a esses, como Kokoschka, de Viena, e Feininger, o americano-alemão ${ }^{156}$.

As histórias dos movimentos de vanguarda são mais complexas, ambíguas e contraditórias do que qualquer pequeno resumo permite mostrar. A referência a estes dois movimentos tem o propósito de indicar a convergência de certos eventos que acabaram por definir a data de 1905 como marco inicial da Vanguarda, a partir da qual inúmeros movimentos artísticos foram surgindo, numa escala ampla entre os mais e menos radicais com relação a inovações estéticas, ou numa escala de maior ou menor disposição de articulação com movimentos políticos e sociais. Costuma-se apontar o Cubismo e o Futurismo (1909), o Dadaísmo (1918), o Surrealimo(1924) como os mais radicais e expressivos movimentos da vanguarda.

Nos movimentos que têm o simbolismo e o romantismo como influências diretas como o expressionismo, são identificadas atribuições como a Durchgeistigung, ou seja, “um significado espiritual a toda e qualquer ação"157. Com relação ao Simbolismo de meados do século XIX, Michael Gibson denominou sua representação de "sublevação espiritual”, ou ainda de "impressão negativa de uma idade desaparecida, rica em símbolos, assim como a expressão de anseio e dor perante a perda de um passado cada vez mais idealizado”"158. Até certo ponto é romântica, mas impregnada ao mesmo tempo da mentalidade católica da França. ${ }^{159}$.

Em oposição aos “descendentes” do Simbolismo, tem-se uma arte concreta, material, formal, construtivista, tecnicista, científica, futurista que vai se prevalecer e se desdobrar. Várias tentativas serão feitas no intuito de retomá-la em vão. O projeto radical da Vanguarda terá sido uma experiência moderna única, cujos sucesso e fracasso deixaram marcados para sempre a "arte” que se pode fazer no "presente”.

\footnotetext{
${ }^{156}$ Lynton, N., 2000, p.27.

${ }^{157}$ Lynton, N., 2000, p.27.

${ }_{158}$ Gibson, Michael. Simbolismo. Concepção: Gilles Néret. Colônia, Alemanha: Taschen, 2006, pp.15-24

${ }^{159}$ Gibson, Michael. 2006, pp.15-24.
} 


\title{
As vanguardas russas
}

O livro de A. M. Ripelino, Maiakovski e o teatro de vanguarda, parece ter sido a primeira iniciativa para mostrar ao Ocidente a complexidade do movimento das vanguardas russas. A tradução desta obra para o português, em 1971, pode ter representado também um esforço de atualização cultural com relação a um país, cuja história de revolução e marxismo influenciara a criação de partidos marxistas no mundo todo e especialmente na América Latina como o estudo do brasilianista soviético Boris Koval demonstra. Publicado em espanhol em 1978, A grande revolução de outubro e a América Latina, embora possa soar hoje um tanto apologético com relação ao crescimento e fortalecimento dos partidos socialistas latino-americanos (o que foi desmentido pelos acontecimentos sócio-políticos das décadas posteriores), merece o reconhecimento ao mapear na região

\begin{abstract}
as atitudes das classes e dos diferentes grupos sociais ou políticos latinoamericanos, em relação à Grande Revolução Socialista de Outubro de 1917 na Rússia, a influência deste acontecimento no desenvolvimento da luta de classes e dos movimentos democráticos de massa do continente, a evolução político-ideológica do movimento operário, a adesão dos proletários e intelectuais mais progressistas da América Latina às posições do marxismo-leninismo, as mudanças operadas no processo revolucionário continental, sob o impacto da Revolução de Outubro, etc. $^{160}$
\end{abstract}

Obviamente as formas de agit-prop, de teatro de agitação, de teatro jornal, vieram junto. Entretanto, pouco se sabia até meados da segunda metade do século XX, sobre as inovações e experimentações artísticas imediatamente pré- e pós-revolucionária, em virtude primeiro da imposição do realismo socialista e, em segundo, sobre o silêncio imposto até 1956 sobre as personalidades mais expressivas tanto do futurismo russo quanto de outros movimentos de vanguarda do período.

É justamente isso que Ripelino comenta no início de sua obra. Ele afirma, por exemplo, que "ninguém (...) ousaria negar que o grande incêncio da vanguarda russa depois da revolução tenha estalado da centelha do futurismo" ${ }^{161}$. E segue assim:

\footnotetext{
${ }^{160}$ Cf.: "Prefácio da edição soviética em espanhol”, p.VII. In Koval, Boris. A grande revolução de outubro e a América Latina. São Paulo, Alfa-Omega, 1980.

${ }^{161}$ Ripelino, A.M. Maiakovski e o teatro de vanguarda. São Paulo, Perspectiva, 1971, p.12.
} 
Quem seria tão obtuso a ponto de não reconhecer que o teatro de Meyerhold, de Eisenstein, do grupo FEKS, a escola filológica dos formalistas, o suprematismo, o construtivismo e várias outras correntes de poesia e de pintura afundam suas raízes nos experimentos futuristas? (...) Os cubo-futurisas surgiram em abril de 1910, com o almanaque Sadók sudiéi (o Viveiro dos juízes), redigido por Vielímir Khliébnikov, David e Nicolai Burliuk, Vassíli Kamiênski e Elena Guro ${ }^{162}$.

Enquanto Ripelino nega a influência do futurismo italiano de Marinette, que fez uma excursão pela Rússia em 1914, sobre o futurismo russo, François Albera mostra em estudo mais recente que isso é "totalmente inexato"163. Que "os artistas russos aprendem com os italianos”, por exemplo, “essa nova forma de ação que é o manifesto, a proclamação ou a vaia”" 164 . Mostra também que, segundo Susan P. Compton, “uma das preocupações da vanguarda russa era manter a primeira posição entre seus rivais na Europa, e, evidentemente, certos escritores e artistas começaram, desde 1913, a fornecer datas incorretas”165. Mas não se pode negar, que "Marinetti inventa uma política da luta artística, cujos meios são a propaganda, os panfletos, a ação direta (...), as reuniões provocantes (...) as declamações públicas”166. E, principalmente, que "o futurismo foi o primeiro movimento de vanguarda histórica. Ele representa, nesse século, o próprio nascimento da vanguarda”"167. Pois "ele precede os imagismos, o dadaísmo, o construtivismo, o surrealismo e o impulso do expressionismo, ainda que tenha surgido depois do cubismo pictórico” ${ }^{\text {. }}$. François Albera afirma finalmente e com conviç̧ão, que:

Todos os movimentos "de vanguarda" desde a década de 1910 - na França e no resto do mundo - são confusamente ligados a um componente social: as proclamações de "arte pura" não são diferentes, e os críticos, os adversários dessas transformações formais os assimilam a correntes político-sociais. Os cubistas são tachados de "anarquia", seu procedimento é assimilado ao de uma expedição "militar" ou "militante", e Appolinaire evoca de modo bem misterioso a dimensão "social" de Braque. Pode-se, portanto, conjecturar que a situação das lutas políticas na Rússia, o tipo de debate e de controvérsia e a "literatura" a que davam

\footnotetext{
162 Ripelino, A.M, 1971, p.12-15.

163 Albera, François, 2002, p. 176.

164 Albera, François, 2002, p. 177.

${ }^{165}$ In Colloque international K. Malévitch, 1979, pp. 51-8; apud Albera, 2002, p.176.

${ }^{166}$ Albera, François, 2002, p. 176.

${ }^{167}$ Lista, Giovanni, 1973, p.16 apud Albera, François, 2002, p. 176.

${ }^{168}$ Segundo a nota 62 de Albera na página 201, referente à obra de Jean Weisgerbert, "Lê saut dans l'avenir du temps des avant-gardes: la conception de Marinetti et la discontinuité”, in Présence de Marinetti, atas do colóquio organizado pela Unesco, em 1976. Lausanne d’Homme, 1986, p.115.
} 
lugar (literatoura, em russo, tem um uso extensivo, qualificando, com freqüência, os escritos políticos ou econômicos da imprensa revolucionária) tiveram um efeito sobre a prática "política" dos futuristas, e é possível dizer que esta procede de uma imitação da prática política revolucionária. A relação, antes da revolução, é talvez hipotética, mas é indubitável depois e à medida que se aprofunda o engajamento futurista, construtivista e produtivista na "reconstrução da vida cotidiana"169. [Grifos do autor].

Por isso não é absurdo afirmar que parte do ideário que mobilizou as forças revolucionárias do teatro latino-americano a partir dos anos 60 já estava em pleno andamento na Rússia pré e pós-revolucionária. E as suas figuras ímpares, além de Maiakovski na poesia, seriam Meyerhold no teatro e Eisenstein no cinema.

François Albera assevera sobre a influência direta do debate russo sobre Brecht, cujo prestígio no teatro da AL é sempre enfatizado por estudiosos. Ele afirma em determinado momento que a Alemanha era uma verdadeira caixa de ressonância para tudo o que se passava na Rússia ${ }^{170}$ em termos de inovações estéticas e vanguardistas. Além disso, a aproximação dos artistas da vanguarda russa aos princípios do anarquismo, fez com que todos abraçassem o partido bolchevique pós-revolução, por vislumbrarem a possibilidade de concretização dentro do estado de direito político socialista, seus ideais bem concretos com relação à aproximação entre arte e vida. Ele refuta a crença de que a politização do movimento de vanguarda tenha esvaziado o movimento. Pelo contrário, foi a guinada à direita do partido comunista, no que concerne à arte, que obrigou a dissolução do movimento na Rússia.

Tal como aparece em Bürger, Albera também evoca o conceito de "poética do choque”, identificando uma linha de continuidade de Cézanne ao Outubro russo, para abordar tanto a experiência da vanguarda russa quanto a do construtivismo eisensteiniano.

Eisenstein, ex-aluno de Meyerhold, depois de ter passado pelo teatro acaba por se dedicar ao cinema, introduzindo inovações que marcaram a sua história, principalmente, a partir da formulação do conceito de montagem. Para ele, a montagem é uma propriedade orgânica de todas as artes. No cinema, este princípio consiste no fato de que "dois pedaços de filmes de qualquer tipo, colocados juntos, inevitavelmente criam um novo conceito, uma

\footnotetext{
169 Albera, François, 2002, p. 177.

${ }^{170}$ Albera, François, 2002, p. 13.
} 


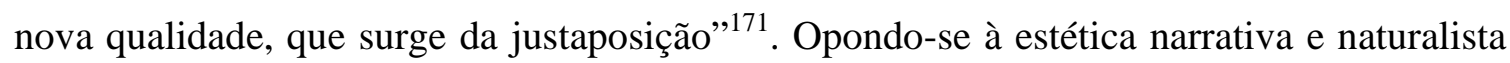
do cinema clássico, propõe inicialmente a idéia do cinema intelectual, cujo exemplo apontam-se o filme Outubro. Segundo Albera, Eisenstein participa do movimento construtivista pela via do teatro. Antes de passar ao cinema, ele se dedicaria ao teatro, paixão que surgira ainda em 1912 ao assistir a uma peça de teatro, e se consolidou ao assistir em 1917 a peça Mascarada, de Lermontov, dirigida por Meyerhold. A partir daí, abandonou o curso de arquitetura definitivamente e passou a trabalhar no teatro. Foi assistente de Meyerhold, a quem reverenciou a vida toda, a despeito de todas as discordâncias que passou a ter com o criador da biomênica e forjador do termo “construtivismo” que deu nome à estética que estavam pesquisando.

\section{Meyerhold}

As palavras no teatro são só bordados na tela dos movimentos. Meyerhold

Há uma vasta lacuna na história mundial do teatro que ainda permanece quase na penumbra - pelo menos, nessa região do globo. Trata-se das manifestações, na Rússia, pré e pós-revolucionária, do teatro de agit-prop. Ele é considerado o princípio a partir do qual foi possível a formulação da idéia de teatro político - noção que impulsionou inovações no teatro alemão da década de 20, por meio das produções de seu maior defensor: Piscator. O teatro de agit-prop, agitação e propaganda, foi duramente criticado pelos especialistas da arte no transcorrer do século XX, cujo argumento - segundo o qual, a instrumentalização do teatro à serviço de uma ideologia o empobrecia, uma vez que a pesquisa estética deixava de existir ou ficava relegada a pano de fundo - acabou por prevalecer no imaginário da grande maioria dos "artistas" do "nosso tempo".

Esse argumento pode ser mais cuidadosamente verificado. Há uma outra série de dados que tornam mais complexa essa experiência do agit-prop russo, como por exemplo, a vinculação a esse movimento de artistas ligados à "arte de vanguarda”. Jamais ocorreu questionar, dados as evidências, a importância decisiva que o papel das vanguardas artísticas européias e russas desempenharam no curso da arte contemporânea. Essa

\footnotetext{
${ }^{171}$ Eisenstein, S., 2002, p.14.
} 
vinculação da arte com a política aparece mais explicitamente na figura do encenador Meyerhold, para quem a revolução no teatro e a revolução nas ruas estavam mutuamente imbricadas.

Aparentemente paradoxal, foi ele quem lançou as bases de umas das principais tendências do teatro moderno/contemporâneo, por meio da recuperação e exploração da teatralidade, entendido como um recurso amplamente utilizado no teatro tradicional popular presente em várias culturas; criou a idéia de estilização no teatro, experimentou e pesquisou até estabelecer novos princípio para a técnica do ator de teatro, conhecida com o nome de biomecânica.

James Symons ${ }^{172}$ dá início à sua obra sobre Meyerhold fazendo o seguinte comentário:

pode-se questionar se Meyerhold representa para o teatro moderno como seus contemporâneos Isadora Duncan, Igor Stravinsky e Walter Gropius representam para a dança, música e arquitetura. De fato, o crítico Louis Lozowick o descreve como sendo o "Picasso do teatro ${ }^{173}$.

Ele cita um artigo de Norris Houghton para o Jornal de Educação Teatral, onde o autor teria escrito a seguinte afirmação: “Meyer tinha tido uma influência póstuma mais completa sobre todos nós do que nós tínhamos consciência... ele fez o teatro teatral outra vez”.

James Symons observa que “[...] o estudo da carreira, teorias e influências tem sido até muito recentemente incidental e para a maior parte, superficial”. Para ilustrar esta falta de estudo e registro sobre o legado de Meyerhold, Symons traça um quadro bibliográfico sobre o encenador russo.

Depois de mais de uma década do desaparecimento de Meyerhold em 1939, as
fontes mais extensas e confiáveis de informação disponível estava no excelente
mas incompleta biografia de Nikolai Volkovo que cobria a vida e a carreira de
Meyer apenas até 1917, e uma coleção dos escritos de Meyer de 1905 a 1912 sob
o título O Teatr [sobre o teatro]. Para além disso, valioso mais inconcluso relato
do trabalho de Meyer durante e depois da revolução estão contidos nas
descrições de testemunhos visuais do ocidente tais como Norris Houghton,
Huntley Carter, Oliver Saylor, André Van Gyseghen, and Joseph McLeod.
Juntos com um relato fortemente tendencioso dos descendentes de Meyerhold
em direção a um “esteticismo” por meio de uma disciplina antiga, Boris Alpers
(Theatre of the Social Mask), uma cronologia breve do teatro Meyerhold de

172 SYMONS, James M. Meyerhold's Theatre of the Grotesque: the Post-Revolutionary Productions, 19201932. [O teatro grotesco de Meyerhold] Coral Gables, Flórida, University of Miami Press, 1971.

${ }^{173}$ SYMONS, James M, 1971, pp. 
1920 a 1927 por Alexy Gvozdyen, e duas monografias pós-revolução por Meyerhold - Ampluya aktora - o emprego do ator - , escrito com V. M. Bebutov e I.A Aksenov, e Rekonstruktsia teatra [Reconstruction of the theatre] - estes relatos por fascinados/apaixonados ocidentais constituíram a maior parte do material disponível sobre a s atividades de Meyerhold depois da Revolução.

Entretanto, “desde a reabilitação póstuma de Meyerhold em 1956, estudo pelos pesquisadores do teatro russo tem começado a aparecer, assim como material previamente suprimido dos arquivos estatais”. Como conseqüência, é possível ter acesso agora a três publicações muito importantes: Vstrechi s Meyerholdom [Encontros com Meyerhold]; uma coleção fascinante de ensaios em recoleção de seu trabalho com Meyerhold por 47 diferentes contribuidores; V. E . Meyerhold: statyi, pisma, rechi, besedy ( V. E. Meyerhold: artigos, cartas, falas, conversações\}, uma coleção de dois volumes dos pronunciamentos públicos de Meyerhold; e Meyerhold no teatro, a primeira tradução para o inglês, de muitos dos mais importantes artigos de Meyerhold, mais um comentário crítico de Edward Braun.

Outra iniciativa que ajudou a alterar esse quadro foi o fato de que agora "é permitido para memórias pessoais conter referências a Meyerhold”, o que resultou em mais três descrições íntimas e informativas dos modos e métodos de trabalho de Meyerhold: Boris Zakhava’s Sovremniki [Contemporaries], Igor Ilinsky’Sam o sebye [meu íntimo sobre meu íntimo] e Yuri Annenkov’s Dnevnik moikh vstrech [a journal of my encounters] ${ }^{174}$.

A insistência oficial no Realismo Socialista e particularmente o descrédito oficial de Meyerhold de 1939 a 1956, impediu, até recentemente, nenhum reconhecimento público da sua influência. Mas desde 1956, testemunhos e memórias tem começado a aparecer os quais suportam testemunhas para a influência considerável que ele teve e continua a ter sobre o teatro russo e seus artistas. Esta influência é derivada não tanto de seus escritos como das lições e das primeiras idéias absorvidas de Meyerhold pelos jovens dramaturgos, performers, estilistas, e diretores por meio do contato deles com Meyerhold em suas montagens e laboratórios, especialmente nos anos de 1920.

Meyerhold e o agit-prop

\footnotetext{
174 Todo este período foi parafraseado da obra de James Symons.
} 
Há um consenso tácito na crença de que a “arte engajada” ou “política” menospreza a pesquisa estética em detrimento da subserviência a uma causa ou idéia. O teatro seria então um mero instrumento por meio do qual seriam comunicadas determinadas “mensagens”. O objetivo desse trabalho é problematizar essa crença. Para isso, será necessário evocar um dos eventos mais importantes da história do século XX: a Revolução de Outubro, na Rússia, bem como a figura de um dos mais significativos encenadores do "teatro moderno": Meyerhold.

Há necessidade ainda de esclarecer que o interesse em se deter nesse assunto devese em parte a uma busca que teve origem durante o trabalho de pesquisa de mestrado. Até que ponto e de que forma se deu o envolvimento de Meyerhold e outros artistas de “vanguarda ${ }^{175 ”,}$ não só com relação ao movimento de agit-prop, mas também com o próprio partido comunista/socialista russo?

Se o nome de Meyerhold está vinculado ao que de mais inovador se criou no teatro, e se, ao mesmo tempo, está relacionado a um engajamento político-revolucionário, então é preciso refletir sobre uma nova forma de abordar a questão da arte engajada. De qualquer maneira, para se refletir sobre tudo isso, estudar e analisar o trabalho de Meyerhold na Rússia se faz urgentemente necessário.

Evidentemente, não dá para responder a nenhuma dessas questões nesse momento. Esse trabalho se resumirá, portanto, em apontar mais as dificuldades na tentativa de desenvolvê-las do que trazer respostas propriamente ditas.

A primeira dificuldade está relacionada com a língua. O estudo da língua russa demandaria um tempo de estudo que nesse momento se torna inexeqüível, e mesmo que se tivesse tempo para isso, não se encontra com facilidade um curso de língua russa no país.

Há que se resignar com traduções, muitas vezes más, se se quiser desenvolver o assunto. Não há nenhuma tradução das suas obras no Brasil. O que há são obras publicadas sobre Meyerhold que submetem o leitor ao recorte e ao ponto de vista de quem desenvolveu. Assim, há o livro de Jacó Guinsburg, Stanislavski, Meyerhold \& Cia, e a do Aldomar Conrado com $O$ teatro de Meyerhold; todos selecionam o que eles consideram

\footnotetext{
175 Apenas chamar atenção para a palavra “vanguarda”, sobre a qual Iná Camargo Costa demonstrou um certo interesse em desvendar implicações que o vocábulo suscita: "não é estranho que, para designar as criações mais recentes dos artista se tome um termo retirado do universo militar?
} 
como sendo importante comentar sobre o trabalho de Meyerhold. Com relação a este último, há que se ter especial cuidado. Ele não traz informação sobre se a tradução foi feita com base nos originais russos ou se foi feita a partir de obras traduzidas para o francês ou inglês. Cotejando-o com uma tradução em inglês, equívocos foram encontrados ao tratar da idéia de "grotesco".Citemos a passagem de Aldomar, para quem, "o grotesco, segunda etapa no caminho da estilização, termina com a análise. Seu método é o da síntese”; já para James Symons, citando a passagem da obra de Meyerhold traduzida para o inglês, diz o seguinte: "the grotesque, advancing beyond stylization, is a method of synthesizing rather than analyzing”. Ou seja, “o grotesco, avançando para além da estilização, é um método para sintetizar de preferência a analisar”. Uma idéia bem diferente do que a exposta por Conrado. Mas, e se a tradução para o inglês, utilizado por Symons, contiver por sua vez equívocos da mesma natureza da anterior? Fica muito difícil saber. A partir de um ponto é preciso se orientar por aquilo que parece fazer mais sentido. No caso citado acima, tendo em vista toda as inovações propostas por Meyerhold, a abordagem de Symons parece corresponder mais proximamente ao pensamento do mestre russo. Ou então, proceda-se a cotejar várias obras estrangeiras. Isso tudo ilustra apenas a dimensão das dificuldades que este tema engendra.

Com relação às obras em inglês, embora se permaneça sob o jugo de um contato em segundo grau, ao menos é possível encontrar tanto traduções dos escritos completos de Meyerhold, quanto traduções de estudiosos e historiadores russos sobre Meyerhold, como a tradução da obra Meyerhold: the director de Konstantin Rudnisky, traduzido por George Petrov. O original russo é de 1961, a tradução foi publicada em 1981.

Jacó Guinsburg também tem boas sugestões bibliográficas. Em nota de rodapé do seu livro ${ }^{176}$, ele indica como “a mais qualificada pesquisadora ocidental nesse domínio" Béatrice Picon-Vallin, que traduziu para o francês a obra de Meyerhol: Ecrits sur lê théatre, Tome I - 1891-1917 $7^{177}$. Além dela, outros estudiosos franceses tais como Nina Gourfinkel, Claudine Amiard-Chevrel ${ }^{178}$ são referências importantes.

\footnotetext{
${ }^{176}$ GUINSBURG, Stanislávski, Meyerhold \& Cia, p.9.

${ }^{177}$ PICON-VALLIN, B. Ecrits sur le théatre. Lausanne, La Cite -L'Age d'homme, 1973. Tomo II e III.

${ }^{178}$ Le Théatre d'agit-prop de 1917 a 1932, vol.I, vol.II, vol.III e vol. IV.
} 
Depois dessa breve digressão sobre a bibliografia do tema. Inicia-se então alguns apontamentos sobre o tema. Antes, contudo, é necessário apresentar o contexto no qual o trabalho de Meyerhold se desenvolveu. O período da revolução russa é muito pouco conhecido no Brasil. Muito menos ainda, períodos anteriores da história da Rússia. A obra de Huntley Carter $^{179}$ poderá auxiliar nisso.

Segundo Carter, desde 1861 detecta-se camponeses lutando pela liberdade, quando eles já eram emancipados legalmente mas não política ou economicamente. Essas idéias foram o resultado do modo como foi convertido na Rússia as aspirações e os princípios alardeados pela Revolução Francesa. Logo em seguida cairam sob a influência marxista. Esses marxistas fizeram de tudo para tornar conhecido a importância do teatro feudal, agora tornado popular, para o movimento revolucionário geral. Por meio deles tornaram-se um instrumento definido de agitação sistemática, de angariar votos na massa para a crença das teorias econômicas e revolucionárias.

Os proprietários prometeram terra aos camponeses mas não a deram. Como resultado eles foram forçados a trabalhar para seus proprietários/Senhores de terra, e acorrentados em suas comunidades. Uma série de dramáticas insurreições começaram a ocorrer. Levantamentos mais sérios foram provocados pela crueldade dos donos de terra e seus servidores; e como conseqüência tropas eram envolvidas no conflito rebeldes em todo o lugar. Havia uma guerrilha nuclear que mais tarde ardeu na insurreição clássica de Pugatchev.

As idéias marxistas estavam sendo amplamente difundidas ${ }^{180}$ entre operários e camponeses, esboçando o início da organização dos trabalhadores junto a partidos comunistas e socialistas, ${ }^{181}$ então nascentes, e sindicatos. Marshall Berman relata sucintamente um dos primeiros momentos da organização da população da cidade de São Petersburgo $^{182}$ (a atual Leningrado), numa manhã do dia 4 de dezembro de 1876: "várias

\footnotetext{
${ }^{179}$ CARTER, H. The new spirit in the Russian Theatre.

${ }^{180}$ Inicialmente, por meio do livro Concepção materialista da História de Plekhanov.

${ }^{181} \mathrm{O}$ primeiro grupo marxista russo, que se denominava social-democrata, foi fundado por exilados, entre eles Lenin, em Genebra, em 1883. Em 1897 foi criado em Kiev, na Ucrânia o grupo socialista-revolucionário. O Partido Socialista-Revolucionário foi formado em 1901. Informações contidas no livro de Florival Cáceres. História Geral. São Paulo, Moderna, 1988.p.

${ }^{182}$ Cidade, cujo nome fora mudado para Leningrado durante o período socialista, mas que a partir de 1991, voltou a ser denominada São Petersburgo.
} 
centenas de pessoas, na Nevski, subitamente se amalgamaram numa multidão [...] constituída de estudantes, funcionários, desempregados e intelectuais sem filiação a qualquer credo”( BERMAN, 1986, p.221):

Grupos de trabalhadores e intelectuais têm se encontrado e se falado intermitentemente desde o início da década de 1870 - literalmente no subterrâneo, em porões isolados na margem de Viborg -, mas nunca apareceram juntos em público. Quando se juntam agora, na praça Kasan, não sabem bem o que fazer. Formam uma multidão bem menor do que aquela esperada pelos organizadores e ocupam um lugar pequeno no vasto espaço público da colunata. Estão agitados e a ponto de se dispersar quando um jovem intelectual, de nome Georgi Plekhanov, decide aproveitar o dia: sai do meio da multidão, faz um discurso curto e inflamado que conclui com "Salve a revolução social" e desfralda uma bandeira onde se lê Zemlia i Volia, "Terra e Liberdade" 183 (BERMAN, 1986, p.221).

De volta a Carter, ele disserta:

Com a introdução do Marxismo, começou uma era definida de luta de classe pela liberdade. Cerca de 1880, ou 8 anos antes do assassinato de Alexandre II por anarquistas, os Social-democratas compostos por dois partidos, Mencheviques, ou Partido da Direita Revolucionári; e Bolshevists, Partido da Esquerda Revolucionária, tomaram o controle, e começou uma nova fase de agitação e organização. Era influenciado principalmente pela filosofia de massa marxista, de fato a nova totalidade de classes. Religião de massa. A massa como Deus ou completa união com o externo, que é, o mundo objetivo. Fé de massa no comunismo como um instrumento de libertação social. Marxismo foi rapidamente difundido entre os camponeses e nas áreas industriais pelos bolsheviques; e nas cidades e vilas pelos menscheviques, incluindo as classes de intelectuais e professores.

Por isso, marxistas com sua idéia fundamental de liberdade de massa voltaria sua atenção para os operários e trabalhadores das indústrias urbanas, que eram na verdade camponeses atraídos para as grandes cidades pela invasão do industrialismo europeu ocidental.

\footnotetext{
${ }^{183}$ Nome da organização dos primeiros socialistas russos, os narodniks, os quais diziam que a edificação do socialismo na Rússia seria feita através da via camponesa, com a restauração da comuna rural, cabendo aos intelectuais o pqpel de direção do processo revolucionário. Mas ela não sobreviveu às desconfianças do campesinato e às ações da polícia política e da Igreja ortodoxa (CÁCERES, 1988, p.219).
} 
Essas idéias foram inteligentemente usadas pelos agitadores para fazer hostilidades ao imperialismo capitalista e individualista. Os trabalhadores camponeses conservaram seus instintos dramáticos primitivos, que os capacitaram, como o tempo continuou, para estabelecer inumeráveis organizações teatrais e para expressar seus objetivos e indignação espontaneamente sem aquele treinamento teatral que se tornaria tão na moda nos teatros patrocinados pelas classes média e superior.

“A série de históricas revoltas camponesas culminaram”, influenciadas pelo Marxismo, com a fracassada Revolução de 1905 em toda a Rússia. Os incidentes dessa luta contribuíram para a luta de classe contida no Novo Teatro.

Durante essa fase da luta de classes mais de 5.000 clubes e organizações teatrais de características revolucionárias foram estabelecidas com mostra claramente que a nosva proposta do teatro russo como um instrumento de liberdade social tinha se enraizado. A revolução de 1905 foi derrotada e as organizações teatrais revolucionárias foram parte suprimidas e parte caíram na clandestinidade durante o regime tsarista, quando formaram oraganisações teatrais de agitação secretas.1906 a 1917 foi um período de complôs e contra-complôs, perseguição do partido de esquerda revolucionária.

A revolução de outubro, junto com as tentativas de cumprir suas promessas (que fez uma nova ordem de sociedade), inaugurou a época do Novo Teatro russo. Estes eventos localizam-se indiretamente, sob o governo do proletariado (um termo feito que inclui operários de fábricas, camponeses, soldados e vendedores) de quem , em colaboração com diretores intelectuais e instrutores, subseqüentemente devolvido a tarefa de restaurar o teatro de sua função vital. Foi o negócio dessa representatividade das asas da Esquerda do teatro reintroduzir o conteúdo e a forma na centro da vida para o teatro.

As iniciativas que desembocaram nesses movimentos de agitação e propaganda políticas durante as primeiras décadas do século XX, remontam ainda aos fins do século precedente, isto é, ao final do século XIX, quando já tinham sido postos em movimento diversos embates no âmbito da arte e da política. Com relação às artes, o movimento geral 
explodiria no ímpeto arrojado das vanguardas artísticas, ${ }^{184}$ variadas, contraditórias, todas proclamando ruptura com a tradição.

Fora dado o início do grande processo político que levaria à revolução socialista, impulsionada por vários grupos sociais entre os quais os trabalhadores, agora saídos do mundo "subterrâneo" para a visibilidade nos centros da cidade por meio da atitude ativa e militante. De forma intermitente devido à repressão da polícia política, essas pequenas organizações vão crescendo em torno de partidos, clubes, associações etc. Prefigurava-se o ambiente propício às agitações e propagandas políticas, cujo instrumento seria o teatro. Durante o período pré e pós-Revolução co-existiriam diferenciados grupos auto-ativos, os quais seriam uma espécie de embrião do que viria a ser o movimento de agitprop:

...na base de toda essa ebulição cultural [encontravam-se] os grupos auto-ativos: Muitos têm vida anterior à Revolução e organizam-se em torno dos clubes operários, vinculados a fábricas e núcleos de bairro e são apoiados pelo Partido, pelos Sindicatos e por organismos soviéticos como o KOMSOMOL, União de Jovens Comunistas. São coletivos de produção artística que congregam diferentes 'círculos', abrangendo os diversos aspectos da educação política e da vida cultural de seus membros. Desempenham também um papel de reprodutores, formando e estimulando outros coletivos, obedecendo à urgência de se promover a organização nos meio proletários” (GARCIA, 1990, p.6).

Auto-ativismo, segundo citação da autora, teria sido definido por Amiard-Chevrel como uma "ação das próprias massas para criar um fragmento da cultura da sociedade que está nascendo;”185 ou seja, “...reivindicar (...) seu espaço cultural próprio, fora da cultura hegemônica das outras classes”. Este movimento elegeria o teatro como o instrumento ideal de agitação e propaganda políticas, tendo como “principal animador”, nos primeiros anos revolucionários, Pavel M. Kerjentsev - “alto funcionário do Partido, teórico do Proletkult ${ }^{186}$ e diretor da ROSTA” - , por meio de quem, surgiu o “teatro operário” que é caracterizado como uma “formação de núcleos locais, estruturados como coletivos artísticos; [com]

\footnotetext{
${ }^{184} \mathrm{Na}$ época das vanguardas artísticas explodiu uma rebelião contra todas as formas artísticas tradicionais. Surgem o dadaismo e o surrealismo, este último liderado por André Breton. Louis Aragon, Paul Éluard e Philippe Soupault são poetas que participaram do movimento surrealista. In: Literatura Francesa. Enciclopédia ${ }^{\circledR}$ Microsoft ${ }^{\circledR}$ Encarta 2001.C 1993-2000 Microsoft Corporation.

${ }^{185}$ In: Le Théâtre d'agit-prop de 1917 a 1932, v. II, p.38, apud GARCIA, 1990, p. 7.

${ }^{186}$ Segundo GARCIA, trata-se de uma contração de Proletarskaia Kultura. Organização independente, criada em setembro de 1917 pelo Conselho Central dos Comitês de Fábrica.
} 
participação financeira dos membros por meio de um sistema de cotas; elenco flutuante, formado por operários locais; manutenção de um estúdio permanente de formação, com a colaboração de especialistas; processo de trabalho aberto à participação das organizações operárias e comunidades locais; independência com relação ao edifício teatral, atuando preferencialmente em espaços adaptados e em lugares públicos abertos”(GARCIA,1990, p.6).

Dentro dessa agitação social e política, pode-se perceber o espírito de Meyerhold com relação a uma demonstração estudantil em 1901, em São Petersburgo, numa carta a Tchekov:

Estou francamente indignado com as ações arbitrárias da polícia, tais como eu testemunhei em São Petersburg em 4 de março, e não posso devotar-me ao trabalho artístico, quando meu sangue ferve e todas as coisas chamam-me para entrar na luta”.

Eu quero (arder)me queimar com o espírito de meu tempo. Eu desejo que todos aqueles que derem suas vidas ao teatro despertassem para sua grande missão. Estou transtornado por meus companheiros que não querem elevar-se acima de sua casta estreita de interesses, interesses estranhos aos da sociedade como um todo.

Sim, teatro pode desempenhar um enorme papel na reconstrução da ordem existente... o movimento social nestes últimos dias elevou meu espírito e despertou em mim tais desejos como eu nunca sonhei. Eu novamente quero estudar, estudar e estudar.

Eu tenho de saber ou me aperfeiçoar ou entrar na luta pela igualdade. Eu quero saber ou se é realmente impossível para cada um ser igual e ao mesmo tempo ser guiado pelo seu próprio conceito de moralidade, que é inofensiva aos outros e entendida por todos como a manifestação de um tipo de espírito.

Então parece-me que é impossível tornar-se “mestre” quando a luta social coloca você no posto dos “escravos".

Eu corro e tenho sede de conhecimento.

E quando eu olho minhas mãos magras, começo a me odiar por ser impotente e fraco como estas mãos que jamais teve os punhos fortemente cerrados.

Minha vida parece-me demorar, crises dolorosas em alguma doença terrível. E eu somente espero e espero para que a crise seja resolvida de um modo ou de outro. O que vem não me assusta, se apenas o fim viesse breve, algum fim"

Nesta carta, Meyerhold deixa entrever suas próprias inquietações com relação às lutas sociais espalhadas por toda parte, e uma predisposição interna em fazer parte dessa luta. Por isso quando estourou a revolução de outubro, ele foi um dos primeiros artistas a se integrar no partido comunista e ser um líder teatral atuante e inovador.

A inovação artística de Karl Theodor Kasimir Meyerhold (1874-1940), cujo nome russo era Vsevolod Emilievich Meyerhold, desenvolveu-se dentro desse quadro, tributário

\footnotetext{
${ }^{187}$ Pis'ma Meierhol'da k Chekhovu, Literaturnoenasledstvo. Apud RUDNISKY, K. Meyerhold: the director, p.14.
} 
de todo o processo que resultou no outubro vermelho. Tendo começado sua carreira de ator no Teatro de Arte de Moscou, de Stanislavski e Nemirovich- Danchenko, cuja ruptura se dá após cinco anos de trabalhos, só começará a esboçar os princípios inovadores de sua arte teatral quando cria o seu Estúdio da rua Borondiskaia. Essa fase do encenador, de inícios de 1913, é o momento em que realmente começa a dar forma a idéias como o "princípio da estilização” e da “convenção consciente”; mais tarde, o "princípio musical da construção dramática; o princípio plástico da estilização cênica; o elemento do grotesco”, bem como dá início à elaboração da "biomecânica” e a sua teorização, mostrado na revista Liubov K Trem Apelsinam (O amor das três laranjas), publicada entre 1914 e 1916, sob a direção do próprio Meyerhold.

Nesse momento, a reflexão de James Symons ajuda a compreender seus principais idéias do teatro teatral de Meyerhold. Segundo Symons, Arthur Miller ficou “impressionado com ‘a fisicalidade da atuação”” no teatro Russo. (...)“muito dessa montagem é coreografia nem melhor nem pior do que sua contrapartida em qualquer lugar, mas havia sempre alguma coisa explosiva na concepção que fala instantaneamente desse gênio particular russo para a fisicalidade”.

O pressuposto do livro de James Symons é a idéia de que o teatro de Meyerhold era essencialmente um laboratório público no qual ele, como um chefe de experimentos, buscava evoluir para uma alternativa viável ao realismo teatral; e uma descrição dessa alternativa.

Segundo o autor, mas este "gênio particular russo para a fisicalidade" não é uma tradição indígena do teatro russo. Pelo contrário, antes de Meyerhold, o palco russo tinha sempre sido de “muitas palavras”. Quando o instinto de Meyerhold levou o a um teatro muito mais robusto e físico, ele teve de encontrar seus predecessores fora da história do teatro russo. Mas começando com as montagens de Meyerhold, a corporeidade - como Miller as chamou - tornou-se um dos aspectos dominantes das produções do teatro soviético.

Esta influência é derivada não tanto de seus escritos como das lições e das primeiras idéias absorvidas de Meyerhold pelos jovens dramaturgos, performers, estilistas, e diretores por meio do contato deles com Meyerhold em suas montagens e laboratórios, especialmente nos anos 20. Do seu primeiro trabalho como um jovem diretor nas províncias 
com a "Confraria do novo drama”, a partir de 1902 a 1906, incluindo sua tentativa em estabelecer o Estúdio do Teatro de Arte de Moscou, em 1905, até sua apresentação não ortodoxa no teatro de Vera Komissarjevskaia de 1906 a 1908, Meyerhold considerou a oficina para abordar suas montagens. Em suas produções, ele invariavelmente experimentava, na base do erro e acerto, com novas idéias e abordagens ( ou um antiga, redescoberta) em vez de funcionar como um coordeandor geral de uma montam normal para a produção do século.

Mas não foi antes de 1913, enquanto dirigia produções públicas no Teatro Imperial de Alexandrinski, e como um anônimo - Dr. Daperttuto - no apartamento de amigos, que ele estabeleceu um laboratório separado para treinar teatro. O Estúdio Meyerhold, uma escola de atuação, aberto no outono de 1913 em uma apartamento amplo na rua Troitska, número 13, em São Petersburgo. Estava destinado a existir até 1917, embora em seu último ano suas atividades diminuíram consideravelmente.

Pelo relato de Yuri Jelagin's, a montagem simbolista de Meyerhld do texto "Snow" de Przybyszewski em 1904 foi a primeiro experimento no teatro não naturalista, convencionalizado no Rússia. Na opinião de Meyerhold, uma renascença do teatro verdadeiro está /fica com a restauração do cabotinismo:

O cabotin é um comediante ambulante; o cabotin é um mimo, histrião, é um malabarista; o cabotin pode fazer milagres com sua maestria técnica; o cabotin deixa sobreviver a tradição da arte verdadeira da atuação. A fim de resgatar o teatro russo de seu próprio desejo de tonar-se o criado/servidor da literatura, nos devemos ter nada para recuperar para o palco o culto da cabotinagem em seu sentido mais amplo.

No estúdio ele cercou-se de professores capazes em vários campos de conhecimento que lel considerou essencial para o cabotin moderno. Para a parte da técnica, havia Yuri Bondi - um amigo próximo de Meyerhold e estilista para alguma das suas produções do Dr. Daperttuto assim como um parceiro no jornal, “o amor das três laranjas”. No estúdio, Bondi ensinava sobre os elementos materiais da produção teatral: cenários, objetos, iluminação do palco, figurino, maquilagem, luz.

O chefe da escola, historiador e teórico era Vladimir Soloviev, um "reconhecido historiador do drama moderno e teatro, da comédia antiga da Ática ao contemporâneo”. 
Embora o próprio Meyerhold fosse profundamente interessado na comédia dell'arte, era Soloviev quem assumiu/comprometeu-se em ensiná-lo no Estúdio, num curso chamado “métodos de atuação na performance da comedia dell'arte. Na aula de “Técnica de falar poesia e prosa”, Karl Vogakha ensinou análise poética em termos de metro e ritmo, como harmonizar os elementos poéticos em uma apresentação oral, e como descobrir o riotmo peculiar para a prosa. O próprio Meyerhold ensinava “Movimento de palco”.

Como talvez fosse esperado, o estudo da commedia dell'arte não era com o objetivo de uma reprodução fiel. Melhor, commedia dell'arte era um um suporte/auxiliar de riqueza considerável em termos de idéias da tradição teatral, significa estudar o objetivo do teatro, e na área prática da técnica de palco” [Gripich]. Era portanto alguma coisa como uma fundação teórica para o que Meyerhold perseguia em sua própria classe: "para Meyerhold, as aulas de Soloviev eram como um degrau em direção ao seu objetivo [de Meyerhold]”.

De acordo com Alexy Gripich, as aulas de Meyerhold, "Movimento de palco” era mais precisamente uma aula de habilidades de atuação e direção:

Meyerhold começou com técnicas de movimento de palco e gesto com exemplos controlados no palco. Os exercícios eram transformados em etudes, e a partir dos etudes resultava a pantomima. Por isso, a partir do exercício lançando uma flecha, surgia " $\mathrm{O}$ Caçador”, e subsequentemente uma pantomima em que todas as gerações do Studio eram envolvidos. Alguns dos exercícios e etudes tornaram-se “clássicos” e mais tarde entrou para o ensino da biomecânica [Gripich].

Em geral, o currículo do Studio era designado pelo cumprimento de cinco objetivos: (1) estudo da técnica do movimento de palco; (2) estudo dos princípios básicos de técnicas de palco da comedia improvisacional italiana; (3) emprego no teatro moderno o método tradicional do século XVII e XVIII; (4) leitura musical no drama; (5) estudo prático dos elementos matérias da produção: construção, móveis e acessórios, iluminação, propriedades, e maquiagem.

\section{Sobre o grotesco}

Na "Barraca de feira" - que o ensaio de Meyerhold , escrito em 1912, cuja referencia tem sido feita (pp. 32-33) - o próprio Meyerhold falou do artista que aproxima sua arte do gortesco: 
Esta atitude abre ao artista um horizonte maravilhoso. De início, ele se ocupa consigo mesmo, com sua própria atitude pessoal com relação ao mundo. Ele seleciona o material de sua arte, não de acordo com o verossímel, mas de acordo com sua sofisticada arte.na primeira etapa, trata a realidade de forma estilizada, sempre levando em consideração, até certo ponto, a probabilidade. "Esquematização" implica um certo empobrecimento do concreto que reduz ao típico.

O grotesco, avançando para além da estilização, é um método de sintetizar em vez de analisar [Symons, p.66; Conrado, p.92]. Ao barrar os detalhes, o grotesco recria a plenitude da vida numa perspectiva “conveniência improvável”, de acordo com a expressão de Puskin. Ao reduzir a riqueza do mundo empírico a uma unidade típica, a estilização empobrece a vida enquanto que o grotesco recusa-se a conhecer apenas uma specto somente o vulgar ou somente o elevado. Mistura-se os opostos e pela forma/desenho acentua-se as contradições. O único efeito que conta é o improvisado, o original [ênfase de Meyerhold].

Essa seção do artigo de Meyer contém a idéia essencial que subjaz seu trabalho experimental durante seu período pré-revolucionário - a improvisação, os etudes, as pantomimas, as peças de Alexander Blok, e programa todo/completo do estudo no Studio Meyerhold.

Meyerhold estipula/diz: “ a arte do grotesco está fundada sobre a oposição da substância e forma”. Ou como diria mais tarde em sua carreira: "eu sei pelos fatos que o que é dito de chiste/piada/brincadeira é freqüentemente mais sério do que o que se diz seriamente”. (Gladkov, Meyerhold fala)..

Para Meyer o grotesco era, o significado mais dinâmico, na disposição dos artista de teatro pra dar expressão à alegria de viver (joie de vivre) que é esquecida muito freqüentemente na vida cotidiana dos homens. E isso deve ser compreendido que para Meyer a alegria de viver era ser encontrado não tanto nos prazeres simples e enfrentamentos silenciosos quanto nos fogos de artifício dos contrastes da vida, conflitos e dissonâncias. Além disso, o grotesco não era para ser construído simplesmente como uma manifestação do ceticismo ou ou distância irônica; melhor, era para ele o envolvimento do artista numa pesquisa de significados: “para além daquilo que nós vemos, a existência é composta de um domínio imenso do mistério. O grotesco busca o sobrenatural, sintetiza a 
quintessência dos contrários, e cria a imagem do fenomenal. Por isso, instiga o espectador a tentar penetrar no enigma do inconcebível”. E Finalmente: “conduzindo o grotesco, o artista tenta causar que o espectador passa de repente de um plano com que ele é familiar, para outro plano que é inesperado”(In Teatro teartral)

P. Meyerhold, o teatro “era, ao invés, um lugar para confrontar uma audiência, por meio de signos convencionalizados peculiar ao teatro, com uma destilação sintética das extremidades da vida em conflito um com o outro - e deixa os risos, gritos, e mexendo-se com vergonha, surgem tão inesperadamente quanto os eventos do palco”.

Em 1917, o Studio Meyerhold, junto com quase todas as outras formas de atividade social organizada, foi fechado pela Revolução. Em 1918 e 1920, ele foi brevemente envolvido com o TEO - laboratórios , mas foi só no outono de 1921 que suas atividades de oficina para a Direção Avançada (GVIRM) foi estabelecido e colocado sob a sua supervisão.

Em 1922, GVIRM publicou um panfleto - Ampluya aktora [ the emploi of the actor] - escrito por Myerhold e seu chefe assistente no GVIRM, Valery Bebutov e Ivan Aksenov. As páginas abertas de seu pronunciamento das idéias e intenções do GVIRM contidas no seguinte declaração:

[O grotesco é] um exagero deliberado e uma reconstrução (distorção) da natureza e unificação dos objetos que não estão unificados nem pela natureza nem pelos costumes da nossa vida diária. O teatro, sendo uma combinação do natural, temporal, espacial, e fenômenos numéricos, está ele mesmo fora da natureza. Descobre-se que estes fenômenos contradizem invariavelmente nossa experiência diária e que o próprio teatro é essencialmente um exemplo do grotesco [minha ênfase]. Surgindo o grotesco de um ritual de máscaras, o teatro inevitavelmente é destruído por qualquer tentativa dada de remover o grotesco - a base de sua existência - dele [Gorchakov, o teatro na união soviética].

E a idéia do grotesco no teatro não era para Meyerhold um escolha de moda ou convenção; para ele, o teatro era inerentemente grotesco: "um exagero deliberado e reconstrução... da natureza e a unificação de objetos que não estão unidos nem pela natureza nem pelos costumes de nossa vida diária”.

Elementos de atuação dos princípios da biomecânica:

“um tratamento especial e necessário aos atores é a habilidade de responder a estímulos aplicados aos seu reflexos... O estímulo é a habilidade para cumprir uma missão recebida de fora por meio dos 
sentimentos, emoção e linguagem. Para coordenar as reações ao estímulo é o que constitui a atuação. As partes separadas disso são os elementos de atuação, cada um dos quais tem três fases: a) Intenção; b) Realização; c) Reação. A intenção é a percepção intelectual da tarefa recebida de fora (do autor, do dramaturgo, do diretor, ou da iniciativa do próprio ator).

Realização é a série de reflexos da vontade, mimética e vocal.Reação é a diminuição do reflexo da vontade de acordo com a realização dos reflexos miméticos e vocais. O reflexo da vontade é preparado para receber uma nova intenção e e prossegue para um novo elemento de atuação".

Esse trabalho visa, portanto, compreender mais profundamente, as relações da pesquisa estética e sua inovação da arte teatral de Meyerhold com os movimentos da vanguarda política que estavam difundidos por toda parte nesse período. Esse é apenas um intróito a esse universo complexo. 


\section{ANTECEDENTES HISTÓRICO E POLÍTICO DO NUEVO TEATRO COLOMBIANO}

\section{A década de 50}

\section{Os anos da violência}

"Anos de la violência”, assim ficou conhecido o período de 10 anos aproximadamente, durante os quais, liberais e conservadores se confrontaram ferozmente numa guerra civil, desencadeada principalmente pelo assassinato do líder liberal Jorge Eliécer Gaitán, em 9 de abril de 1948. Este fato foi o ponto de ruptura para a escalada da violência, que só seria estancada com a ditadura militar do general Gustavo Rojas Pinilla, instaurada por meio do golpe militar, ocorrido em 13 de junho de 1953.

As causas de todos esses eventos remontam ainda aos anos 20-30, durante os quais se assiste à implementação das "relações capitalistas de produção". "Na Colômbia, os burgueses desses anos também foram irreverentes e audazes; eram homens orientados pelo cálculo egoísta e o “interesse frio’”, ${ }^{188}$ Do ano 30 ao 46, a direção da vida política da nação esteve nas mãos dessa burguesia em nome do partido liberal, ${ }^{189}$ representada nos governos de homens como Enrique Olaya Herrera ( ), Alfonso López Pumarejo ${ }^{190}$ ( ) e Eduardo Santos ( ), cujos frutos podem ser enumerados do seguinte modo:

Entre 1933 e 1938, a taxa média de crescimento foi de 10\%, o número de estabelecimentos industriais duplicou, o produto bruto industrial elevouse de maneira significativa, e o investimento público mais que triplicou. Esse processo de decolagem, contudo, encontrava limites, derivados da reduzida diversificação da produção, das dificuldades para ampliar a produção de bens de capital (que restringiam o aprimoramento da capacidade produtiva) e da limitada produção agrária (que forçava o gasto de divisas na importação de matérias-primas). Essas dificuldades foram agravadas pelos efeitos da Segunda Guerra Mundial, que encareceram as importações de bens de capital e provocaram o fechamento dos mercados internacionais para as exportações nacionais,

\footnotetext{
${ }^{188}$ Nuevo teatro en Colômbia, p.16.

${ }^{189}$ Nuevo ...p.18.

${ }^{190}$ Carlos José Reys registra em seu texto “Investigar el teatro. El teatro de la violência”, que o presidente López Pumarejo estabelece a Revolução em Marcha em 1936, que causaria terror tanto nos filiados ao partido conservador quanto no clero.
} 
com as decorrentes conseqüências da queda dos níveis salariais e o aumento do desemprego. ${ }^{191}$

Apesar destas dificuldades todas, a atividade industrial adquiria um dinamismo vertiginoso, traduzido numa taxa média de crescimento anual de 9,4\% durante o período 1945-1953, processo que foi acompanhado pelo aprofundamento de seus traços monopolistas. ${ }^{192}$ Devido a estes anos de governo liberal, reformas de ensino e uma relativa mobilidade de classe foram estimuladas, contribuindo para uma "plebeyización” - isto é, maior acesso de estudantes provenientes das classes baixas a esses níveis de ensino - da educação universitária e secundária e a formação de novos e mais numerosos intelectuais entre as classes médias baixas. ${ }^{193}$ Convém evocar o quadro dramático que Eduardo Gómez descreve destas novas gerações:

O adolescente das classes médias baixas que estuda, o jovem trabalhador ou camponês que começa a ler e a ir ao cinema, a escutar ao rádio ou a fazer parte de um sindicato, percebem com rapidez (e com a visão direta, limpa e um tanto rígida, de uma idade que todavia não tem interesses criados) que o pai, como representante da autoridade e da lei, é (em maior ou menor grau) um filisteu, que a mãe é demasiado limitada por uma piedade hipócrita e uma ignorância que não compensa sua bondade. As convenções familiares são postas em questão por uma sexualidade precoce (geralmente cínica ou pornográfica) fomentada pelos meios de comunicação modernos e o espetáculo cotidiano das chagas abertas das grandes cidades, e é assim o modo que se suscita uma dessacralização dos laços familiares que lança a juventude (em geral universitária) à aventura, à busca e à independência. A transmissão da ideologia dominante, realizada tradicionalmente no seio da família de pais e filhos, fica assim gravemente afetada (sobretudo nas cidades) e se inicia um corte profundo entre as gerações que (como nunca antes em nosso país) institucionaliza o desprestígio do mundo dos adultos e o assimila cada vez mais à simulação. ${ }^{194}$

“O clima de liberdades relativas e o surgimento de um proletariado advindo da indústria nascente" permitiriam a configuração do movimento "gaitanista", de traço notoriamente populista ${ }^{195}$. Se nos primórdios, os burgueses do partido liberal haviam se unido, contra os conservadores, às populações camponesas - cujas reivindicações e lutas

\footnotetext{
${ }^{191}$ Enciclopédia Latinoamericana, p.323.

192 Enciclopédia Latinoamericana, p.324.

193 Ibidem, p.357.

${ }^{194}$ Ibidem, p.359.

${ }^{195}$ Eduardo Gómez, “Notas sobre la iniciación del teatro moderno em Colombia”, p.357.
} 
tinham um caráter socialista-comunista; e se, de quando em quando, utilizavam idéias marxistas como base teórica para seus projetos, na medida em que o tempo passava, essa contradição interna vai se aguçando até levar a uma guinada radical à direita. Esta idéia está fundamentada na informação trazida pelo historiador Darío Mesa, segundo o qual, "não era raro que os escritores governistas sustentassem sua argumentação no marxismo recém descoberto"196. Como conseqüência disso, era irrefreável a divisão interna do partido liberal, representada pelas figuras de Jorge Eliécer Gaitán (este apoiado pelos populares); e, Gabriel Turbay ( opção da oligarquia liberal, anti-popular e mais conservadora).

Mas não havia como sair dessa situação sem que houvesse desgaste e conseqüentemente o enfraquecimento do partido liberal, o que possibilitou a vitória da oposição, elegendo assim o presidente nas eleições de 1946. Foi nesse momento que o conservador Mariano Ospina Pérez assume o governo. O conflito entre os partidos recrudesce, desembocando no assassinato de Gaitán em 1948, quando então a violência explode, ficando conhecida como o "bogotazo”, "mas ninguém [imagina ainda ] os terríveis acontecimentos que se iniciariam” nesse momento:

A falta de dirigentes populares que houvessem encaminhado o furor e a reação do povo para uma tomada do poder, fez com que este movimento se tornasse caótico e vingativo, perdendo todo seu valor construtivo de mudança. $\mathrm{O}$ povo se lança torpe às ruas numa furiosa reação basicamente anticonservadora e anticlerical. Queimam-se igrejas, assassinam-se líderes conservadores, saqueiam-se o comércio e se atacam oficinas do governo. Esta onda de violência se expandiu aos povos, às províncias e aos campos ${ }^{197}$.

O governo cria forças de choque, aumentando a tensão na população, o que por fim vai dar no conflito armado. Nas eleições de 5 de junho de 1949, frente à evidência do triunfo do liberalismo, "a polícia militar com o objetivo de dizimar as filas eleitorais do

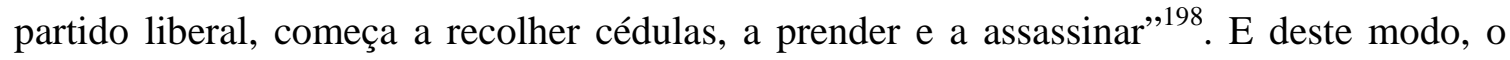
candidato conservador, Laureano Gómez, “obtiene a presidencia sobre montañas de cadáveres”. 199

\footnotetext{
${ }^{196}$ Cf. Colômbia: estructura política y agrária. Ed. Estratégia, Bogotá, 1971, p.32; apud Gonzalo Arcila, op. cit., p.61.

${ }^{197}$ Maria Mercedes de Velasco, El nuevo teatro colombiano y la colonización cultural, p.187.

198 Ibidem, El nuevo..., p.187.

199 Ibidem, El nuevo..., p.187.
} 
Tanto Gonzalo Arcila quanto Eduardo Gómez chamam atenção para a virulência da luta de classes em seu país. "A violência da ditadura conservadora” expôs seus interesses e cumplicidades, de modo que serviu de alerta às novas gerações, tornando-as céticas com relação à política tradicional. No plano mundial, "essa consciência se faz ainda mais ampla depois do assentamento do franquismo com a cumplicidade aberta das democracias burguesas da Europa Ocidental, as quais atuam de forma similar frente ao crescimento e à consolidação do nazismo alemão". ${ }^{200}$ A história da Colômbia, como a da maior parte dos países latino-americanos, formou-se e se desenvolveu sob o signo dessa violência ${ }^{201}$, em que se alternam sistematicamente períodos de ditadura com os de relativa liberdade democrática. Ainda com relação a isso, convém transcrever um diagnóstico feito sobre essa violência na Colômbia:

Em nosso país, a violência, ou talvez, para falar mais precisamente, a segunda violência, a outra, a que nosso povo opõe à primeira, foi tenaz e escavou com a mesma profundidade a ferida. (...) Com a violência se criaram forças populares, reais ou materiais, capazes de assegurar a reabilitação ou a reconstrução do país sobre bases mais amplas e mais sólidas para o posterior processo democrático. ${ }^{202}$

Foi em meio a essa sangüinolência que surgiram os impulsos iniciais que desembocariam na intensa movimentação teatral do final da década de 50, com a formação de grupos teatrais, criação de escolas e produção de festivais. Foi sob a ditadura de Rojas Pinilla que o movimento teatral colombiano começou literalmente a "ferver". Do ponto de vista da produção cultural, quatro eventos vão preparar o ambiente para o surgimento do Primeiro Festival Teatral da Colômbia, que é considerado, sob muitos aspectos, o marco do Nuevo Teatro, a saber, a fundação da emissora da Radio Difusora Nacional; o surgimento da televisão; como conseqüência desta, a chegada de Seki Sano; e, o lançamento da revista Mito.

\footnotetext{
${ }^{200}$ Eduardo Gómez, “Notas sobre la iniciacion del teatro moderno em Colômbia”, p.358.

${ }^{201}$ Ver apêndice 2, onde se encontra um resumo sucinto dos principais conflitos e guerras.

202 Nicolás Buenaventura, no prefácio da obra Nuevo Teatro en Colombia, p.8.
} 


\section{A "Radiodifusora” Nacional}

Os meios de comunicação de massa na América Latina é um capítulo essencial para a compreensão da configuração sócio-cultural da segunda metade do século XX. Podem ser classificados em fases devido "à introdução de quatro avanços tecnológicos fundamentais: a impressão em rotativas; o rádio; a televisão (...); e, ...a informática”, ${ }^{203} \mathrm{O}$ rádio, o segundo avanço técnico, chegou nos anos 1920, com suas primeiras emissoras estabelecidas na Argentina (1921), no Brasil (1922), no Chile (1922) e na Venezuela (1926). Na América Latina,

...o rádio cumpriu uma tarefa integradora em países com populações em grande parte dispersas no meio rural (...). O rádio tornou-se o primeiro veículo de comunicação realmente de massa, atingindo indistintamente públicos de elite e populações pobres, letradas e analfabetas, e inventando um novo discurso comunicativo. ${ }^{204}$

Na Colômbia, a emissora de rádio foi fundada em fevereiro de 1940. Sobre o seu papel no país, Gonzalo Arcilla diria: “foi um verdadeiro dom, em razão de suas difíceis condições topográficas” (p.24). Como sua função primordial era elevar o nível cultural da população, desde sua fundação o primeiro diretor, Rafael Guizado, “deu importância especial à difusão do teatro e à formação de intérpretes”. Isso leva Gerardo Valência a afirmar que:

Naquela época, talvez pela primeira vez, deu-se importância e se estudaram as orientações diferentes que disputavam a primazia na concepção de um nuevo teatro no âmbito mundial. Guizado deu a conhecer, por meio da rádio, o mais importante deste nuevo teatro, e com sentido didático, teve a audácia de fazer, com a direção e assessoria de Romero Lozano, montagens "radioteatrales" de Ésquilo e de Sófocles, encomendar música incidental para a transmissão destas obras, e vincular estudantes e pessoas de suficiente cultura a uma atividade que acabou por se converter numa verdadeira escola de artes cênicas. Este trabalho, continuado com brilho e audácia por Romero Lozano, pode ser considerado o berço do movimento teatral contemporâneo em Colômbia,

\footnotetext{
${ }^{203}$ Idem, Ibidem, p.779.

${ }^{204}$ Idem, Ibidem, p.779.
} 
pois quando veio Seki Sano a ensinar em Bogotá, encontrou já um terreno garantido. ${ }^{205}$

Dando continuidade a essa verdadeira formação de público, a Radio Nacional estrearia obras de autores nacionais paralelamente à transmissão do “mais notável do repertório universal”. Sem falar na divulgação de teorias teatrais avançadas como o caso da concepção inovadora de Edward Gordon Craig, que a Rádio Nacional difundiu para seus ouvintes, acabando por influenciar também os autores colombianos ${ }^{206}$.

\section{O surgimento da televisão}

Por volta de 1950, ocorre o "terceiro salto tecnológico", com o surgimento da televisão em grande parte dos países latino-americanos. "Privilégio de poucos em seus primórdios, em menos de uma década ela já era um fenômeno popular, atingindo regiões distantes das capitais, moldando hábitos, comportamentos e formando correntes de opinião.”207 O poder da televisão mostrou-se quase ilimitado, tanto que o seu surgimento nos principais países da região aconteceu "preferencialmente pelas mãos do Estado"208.

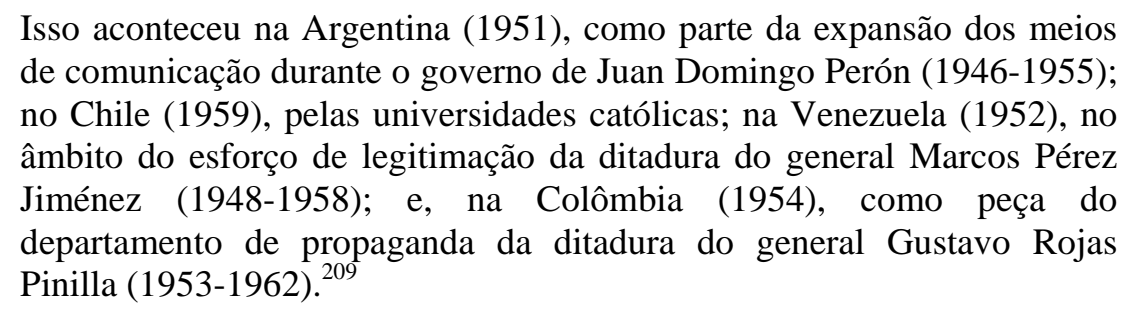

A televisão chegava "a lugares que nem mesmo o próprio Estado [conseguia] alcançar - locais desprovidos de escola, postos de saúde, quartéis do Exército etc.” É nesse contexto que as redes de televisão assumem um "caráter de instrumentos de mobilização, de formação de correntes de opinião”, e atuam “em favor de determinados interesses privados, o que as coloca, muitas vezes, exercendo o papel dos partidos políticos”. ${ }^{210}$ A

\footnotetext{
205 “La actividad teatral en los años de 1940 a 1950”. In Materiales..., p. 275.

${ }^{206}$ Idem, Ibidem, p.276.

${ }^{207}$ Enciclopédia Contemporânea da América Latina e do Caribe. Op. cit., p.780.

${ }^{208}$ Idem, Ibidem, p.780.

${ }^{209}$ Idem, Ibidem, p.780.

${ }^{210}$ Idem, Ibidem, p.782.
} 
capacidade de manipulação da mídia na formação da opinião pública ${ }^{211}$ é quase ilimitada, e ela será uma forte aliada tanto do poder político quanto econômico, podendo agir livre e arbitrariamente de acordo com os interesses da classe dominante. No caso do desenvolvimento dessa mídia na América Latina, só pode ser analisada, tendo “como pano de fundo a hegemonia norte-americana no continente". ${ }^{212}$

Como referido na citação acima, a televisão chegou à Colômbia como "peça do departamento de propaganda da ditadura de Rojas Pinilla”, em 1954. O único interesse do general era fazer propaganda sobre seu governo, e para isso precisava de atores. Para formar atores saiu em busca do melhor diretor de teatro do mundo que falasse espanhol e foi assim que o grande mestre japonês, Seki Sano, desembarcou em Bogotá, em 1955. O que o general Rojas não contava era que o diretor de teatro japonês fosse um homem de teatro sério, que chegara disposto a realizar a tarefa para a qual fora contratado: formar atores e, assim, de onde menos se esperava, começou a surgir em Bogotá, no decorrer de um ano, uma das experiências mais enriquecedoras para o ambiente cultural do país.

Por isso, todos os historiadores não deixam de se remeter ao papel fundante da presença do professor Seki Sano e, parte deles, são levados mesmo a considerar essa presença como marco do advento do teatro moderno no país.

Dessa foram, têm-se nesse momento três importantes antecedentes do Nuevo Teatro: o advento do rádio e do "rádio-teatro"; a introdução da televisão, e a presença de Seki Sano.

\footnotetext{
${ }^{211}$ A despeito de teorias mais recentes que tentam defender um tipo de reação mais autônoma do espectador frente ao discurso televisivo, é impossível não perceber o abismo e a assimetria entre os dois pólos. O poder forte de manipulação da mídia sobre a opinião pública não é um privilégio latino-americano, trata-se de um fenômeno mundial. Valeria a pena conferir a obra de Edward S. Herman e Noam Chomsky, A manipulação do público, São Paulo, Futura, 2003.

${ }^{212}$ Enciclopédia Contemporânea da América Latina e do Caribe. Coord. Emir Sader, Ivana Jinkings. Rio de Janeiro/São Paulo, Laboratório de Políticas Públicas, Boitempo, 2006, p.779.
} 


\section{Seki Sano, o pedagogo}

A importância da presença do diretor japonês Seki Sano em momentos decisivos da história do teatro colombiano (e mexicano) pode ser atestada pela recorrência do seu nome em praticamente todas as obras históricas do teatro colombiano ${ }^{213}$. Entretanto, ele passou a maior parte do seu tempo no México, onde aportou em 1939, como exilado político, depois de ter rodado as principais capitais do mundo ocidental sem conseguir permanência em nenhum país, em vitude de sua afinação política com o pensamento de esquerda. Antes de se dirigir ao México, todavia, Seki Sano passou uma longa temporada de estudos na antiga União Soviética: de 1932 a 1937. Em Moscou, ele “estudou com Stanislavski, assimilou as teorias de Vaktangov e trabalhou como asssistente de Meyerhold”214. No ano de 1937, porém, seria obrigado a deixar também a Rússia, em função da ordem de Stalin em expulsar "a todos os estrangeiros do território soviético" que não tivessem relações com o partido.

\footnotetext{
213 Nota:

${ }^{214}$ Emiko Yoshikawa, “El magisterio latinoamericano de Seki Sano” In: La Escena entre dos mundos, p.9596.
} 
O diretor japonês Seki Sano (Japão, 1905 - 1966, México). Fonte: Revista Escenarios de dos mundos..., p. 95.

Até esse momento, Seki Sano experimentara uma vida de perseguição: primeiro em seu país de origem, onde fora proibido de exercer suas atividades artísticas; depois nos países europeus; e, por fim, na própria União Soviética; quando o diretor encontrou então asilo político no México, depois de o Japão ainda tentar impedir sua estada ali, como fizera antes com sua tentativa de permanecer nos Estados Unidos, país em que Seki Sano recebera visto de permanência de apenas sēis meses, como conseqüência do alerta do próprio governo japonês: ele é um comunista.

“El 26 de abril de 1939, Seki Sano chegava ao México para aí viver até a morte em 1966”. Ao chegar, a Missão Diplomática do Japão no México tentou impedir seu “ingresso e repatriá-lo à força”. Mas graças à “intervenção de intelectuais como Diego Rivera e 
Alfaro Siqueiros conseguiu-se resgatá-lo da crise e o Governo Progressista de Lázaro Cárdenas o admitiu na qualidade de exilado político”215. Ainda segundo o artigo de Yoshikawa, Seki Sano constatou que no México ${ }^{216}$ o próprio governo “tomava a iniciativa nas atividades teatrais revolucionárias”, o que lhe era imensamente favorável.

\section{Seki Sano na Colômbia}

Embora Seki Sano não tenha permanecido muito tempo na Colômbia, cerca de um ano aproximadamente, foi o suficiente para formar um bom grupo de atores, entre os quais, Fausto Cabrera e Santiago Garcia, que mais tarde fundaria o La Candelária. A contribuição de Seki Sano para a formação do teatro "moderno" colombiano seria tão profunda que pode-se atribuir a esse evento um aspecto quase de “fundação". Já fora aludido sucintamente no subtópico anterior o mecanismo que vincula a vinda do diretor ao surgimento da televisão na Colômbia, como estratégia do presidente Rojas Pinilla para divulgar suas ações, informes do governo e exercer seu poder sobre todas as classes e principalmente entre as menos privilegiadas.

Pois bem, a necessidade da contratação de um diretor estrangeiro para formar atores profissionais para a TV surgiu em virtude de o diretor da rádio difusora nacional Romero Lozano (Buga, 1909-1971, Bogotá) não ter tempo suficiente para se dedicar a essa formação. O diretor e ator de teatro Romero Lozano tinha sido o orientador e o pioneiro da rádio e do radioteatro. Ele era a referência do teatro colombiano até então. Em 1946, Bernardo Romero Lozano havia fundado o primeiro grupo de teatro experimental, o grupo da Universidade Nacional de Colômbia, que, junto com a Companhia de Alta Comédia Elvira Travesti de Fausto Cabrera (Medelim) tinham sido os iniciadores deste gênero teatral no país. Lozano dirigiu também a primeira obra para televisão.

\footnotetext{
${ }^{215}$ Emiko Yoshikawa, “El magisterio latinoamericano de Seki Sano” In: La Escena entre dos mundos, p.9596.

${ }^{216}$ Para saber mais sobre atuação de Seki Sano no México, ver "La crítica social en el arte teatral de Seki Sano” de Martha Toriz Proenza, in: http://www.difusioncultural.uam.mx/revista/julioago2000/toriz.html Acesso em 19/06/2006.
} 
Sobre a contratação de Sano, convém citar o ponto de vista do texto de José Eduardo Rueda Enciso:

Su contratación, realizada en México por intermedio del gobierno nacional y bajo los buenos oficios de Jorge Luis Arango, se debió al hecho innegable de que Romero Lozano se encontraba muy ocupado adaptando, preparando y montando el teleteatro, mientras que la preparación de actores estaba totalmente abandonada. A su llegada en septiembre de 1955, Seki Sano organizó la Escuela de Artes Escénicas, dependiente de la Televisora Nacional, donde se iba a continuar la formación y adiestramiento profesional de los actores de televisión y teatro. $^{217}$

Seguindo ainda o artigo de Rueda Enciso, inscreveram-se nesse curso mais de cem atores e aficionados, os mesmos que se tornariam mais tarde estrelas e astros da TV e do teatro. Os alunos de Seki Sano, além de uma dose enorme de entusiasmo, rebeceram uma ótima “preparação dramática moderna” e uma técnica de interpretação aprendida diretamente com os principais nomes russos. O sucesso do curso e de Seki Sano provocou incômodos:

Esta nueva situación molestó a Romero Lozano, pues pensó que iba a ser desplazado de su lugar de preeminencia. Romero vio en el maestro japonés una verdadera competencia y por eso en un acto de macartismo criollo, más envidioso que ideológico, organizó, junto con el declamador Víctor Mallarino, un movimiento cuyo objetivo era sacar a Seki Sano del país, argumentando que el japonés adelantaba labores de proselitismo marxista. 218

Mas em entrevista a Duque Mesa e Prada Prada ${ }^{219}$, Santiago García se refere a outro nome nesse caso. Ele confirma a ocorrência de denúncia contra Seki Sano, mas o responsável por ela teria sido Víctor Mallarino, representante "do teatro da sociedade bogotana mais importante”. Quem denunciou ou não, não importa no final das contas, o que importa de fato é que Seki Sano foi expulso pouco antes de completar um ano no país, pouquíssimo tempo, mas o suficiente para deixar um legado fundamental para a renovação e constituição

\footnotetext{
217 “Bernardo Romero Lozano”. In Gran Enciclopedia de Colombia. Biografias. Circulo de Lectores, 2004. colmbiaArtigo http://www.lablaa.org/blaavirtual/biografias/romebern.htm. Acesso em 19/06/2006.

${ }^{218}$ Este artigo é o único que levanta essa hipótese da interferência de Romero Lozano na expulsão de Seki Sano. Concorrendo com o nome de Romero Lozano, Fala-se também em Victor Mallarino. diz-se também de com tendo sido o delator da orientação comunista de Seki sano, , foi Os demais comentadores referem-se à expulsão apenas como uma iniciativa do governo ao descobrir a orientação comunista do diretor japonês. "Bernardo Romero Lozano”. In: Gran Enciclopédia... op.cit.

${ }^{219}$ In: Santiago García: El Teatro como Coraje. Bogotá: Investigación Teatral Ed., Ministério de Cultura, 2004, p. 84. Obra de entrevista imensa com Santiago García.
} 
do Nuevo Teatro Colombiano. A denúncia que provocou sua expulsão esteve relacionada à descoberta de que Seki Sano teria estudado e vivido muitos anos na União Soviética, o que teria levado à dedução lógica de que ele era comunista e marxista. O que seria, em último caso, mais uma contradição dentro da ditadura militar do General Gustavo Rojas Pinilla. Sobre esse evento, Santiago Garcia faz o seguinte relato:

Em 1954, durante a ditadura militar do General Gustavo Rojas Pinilla, foi inaugurada a televisão em nosso país. E os atores que foram trabalhar ali eram provenientes da radio; tinham uma voz muito boa, mas suas figuras eram muito estranhas, ...muito feios, mas tinham belas vozes.

O governo de Rojas Pinilla, então, resolveu formar atores para aparecer nas telas da televisão, nas telenovelas da época e outros tipos de programas, e deu a ordem de trazer o melhor diretor do mundo para que formasse a estes atores e substituíssem assim aos que vinham formados e que trabalhavam na Radio Difusora Nacional de Colômbia, desde longo tempo, todos cheios de (..) furúnculos e aleijados ${ }^{220}$.

Santiago Garcia conta ainda que o Governo de Rojas Pinilla deu um um bom salário a Seki Sano, alojou-o numa suíte do Hotel Tequendama e colocou a sua disposição tudo o que ele quisesse para formar a escola. Da situação, considerada “cômica” por Duque Mesa, em torno do empreendimento governamental de criar de súbito uma Rede Nacional de Televisão, foi se tornando aos poucos uma tragédia, porque, segundo um de seus mais ilustres alunos, Santiago Garcia,

...Seki Sano era um homem muito sério e não respondia à palhaçada que Rojas Pinilla queria armar: e fundou uma escola de verdade, e começou a formar gente num tempo muito curto e a coisa tomou um cariz muito sério; na realidade o que começou a formar foi atores de teatro, não atores para a televisão e a rádio, ou seja, a encomenda que fizeram a ele começou a ser traída, e o mais grave foi quando alguns meses depois descobriram que era comunista, que era marxista, e que havia estado na União Soviética ao lado dos grandes do teatro mundial: Constantin Stanislavski, Vsévolod Myerhold..., Eugéne Vahktangov já havia morrido ${ }^{221}$.

\footnotetext{
${ }^{220}$ Conf.: Duque Mesa, Fernando; Prada Prada, Jorge. Santiago Garcia: El Teatro como Coraje, op. cit., p. 77.

${ }^{221}$ Duque Mesa, Fernando; Prada Prada, Jorge. Santiago Garcia..., op. cit., p.77.
} 
Destaque-se nessa citação de Santiago Garcia a referência à ligação entre Seki Sano e os ícones do teatro russo. Voltar-se-á a este tema mais adiante. Ainda sobre o diretor japonês, vale a pena citar outro trecho do depoimento de Santiago Garcia:

...a importância fundamental de Seki Sano foi o conhecimento do Sistema de Stanislavski que ele deixou, e isso repercutiu enormemente no desenvolvimento do teatro colombiano. (...) ...trazia um material muito importante que era o sistema de Stanislavski num monte de livros, de tratados, e de diversos materiais que nós não tínhamos aqui ${ }^{222}$.

Duque Mesa, nessa obra de entrevistas com Santiago Garcia, manifesta o interesse em conhecer mais a fundo a personalidade do referido diretor, cuja atuação na inovação do teatro latino-americano ainda é um tema que mereceria um estudo mais aprofundado. Para isso, Duque Mesa recorreu a um material raro, produzido no México, a que a pesquisadora deste trabalho não teve acesso. Por isso, se se quisesse elaborar um pouco mais o traço desta personalidade, seria necessário recorrer ao expediente da citação da citação. Mesmo que o recurso não seja lá muito recomendado, não houve alternativa nesse caso: Duque Mesa reproduz dois documentos importantes: 1. trechos de um artigo, escrito por Michiko Tanaka, publicado em 1996 pelo Instituto Nacional de Bellas Artes y el Centro Nacional de Investigación Teatral Rodolfo Usigli, na Revista Seki Sano, no contexto de homenagem prestada em lembrança dos 30 anos de sua morte; 2. e a transcrição de uma reportagem realizada por Carballido com o mestre japonês, publicada na revista mexicana Tramoya (“Entrevista com Seki Sano”, No. 3, de abril-junho de 1976, pp. 8-11). No trecho do primeiro documento, pode-se ler o seguinte sobre Sano: “...Era apasionado del teatro. Tenía firmeza de caráter, rectitud e inflexibilidad y carecía de diplomacia o delicadeza cuando se trataba de imponer um buen critério del teatro"223. Tinha fama de "ogro”, em função da intensidade de sua cólera durante as aulas ou os ensaios, como lembram muitos ex-alunos. Na reportagem de Cabarllido, ele começa com uma enumeração sucinta das qualidades que marcaram o mestre, assim:

Seki Sano: rosto de asiático que não deixa lugar a dúvidas sobre sua nacionalidade. Renovador do teatro no México, mestre de várias gerações; introdutor da teoria de Stanislavski e do sistema de ensino; responsável de haver formado várias personalidades brilhantes da cena; diretor de várias montagens históricas, inesquecíveis; homem que é

\footnotetext{
${ }^{222}$ Duque Mesa, Fernando; Prada Prada, Jorge. Santiago Garcia..., op. cit., p.84.

${ }^{223}$ Tanaka, M. “¿Quién fue Seki Sano antes de llegar a México?”, 1996, pp.5-6.
} 
indispensável mencionar em qualquer alusão ao movimento teatral mexicano dos últimos vintes anos ${ }^{224}$.

E ao teatro colombiano e latinoa-americano caberia acrescentar. Nessa reportagem, perguntado como entrou em contato com a obra de Stanislavski, Seki Sano vai responder:

Fui a um festival de teatro anual em Moscou. Vivia então em Berlim, havia uma organização que se chamava "Associação Internacional de Teatros Revolucionários”. Fui representando ao Japão. Era 1931. Vi peças teatrais. Fiquei encantado. O contato com Stanislavski foi muito rápido. Entre outros fui ao Teatro de Arte de Moscou, vi o Jardim das Cerejeiras. Pensava então que já me havia graduado, sabia tudo, acreditava que conhecia muito bem a obra. Então, vou ao teatro, abremse as cortinas, com a gaivota pintada, começa a peça. Tudo ia muito correto, muito bem... Aparece a senhora Andreiévna. A casa das crianças, ela aproxima-se do armário, o acaricia, tira o lenço para secar os olhos... E... o que aconteceu aqui? Porque tem isto um impacto terrível? Há algo aqui que não há em outros teatros ${ }^{225}$.

\section{Seki Sano: ponte entre América Latina e "União Soviética"226 / Ponte entre Nuevo Teatro e Vanguarda Russa}

Seki Sano parece ter desempenhado um papel fundamental na constituição do Nuevo Teatro e na renovação da cena teatral latino-americana. Em virtude de sua longa estada e longo aprendizado na Rússia dos anos 30 do século XX, pode-se afirmar sem equívocos que ele representa uma espécie de ponte, um elo importante que conecta as experimentações do Nuevo Teatro Latino-americano dos anos 60-70 aos resultados estéticos russos obtidos no curso de suas primeiras décadas e, sobretudo, de seus anos 20. A seriedade e a consciência de Seki Sano de estar lidando com verdadeiros homens de teatro - cuja genialidade ficaria inscrita na história mundial do teatro do século XX por meio de suas obras e teorias - fizeram com que ele absorvesse o quanto pudesse de seus ensinamentos. É revelador certas passagens do depoimento de Seki a Carballido concernentes a esse período na União Soviética. Ele foi assistente de direção de Meyerhold durante cinco anos ininterruptamente, de 1932 a 1937; participou também de um programa de oficina com Stanislavski para cerca de apenas dez alunos, e estudou os postulados

\footnotetext{
${ }^{224}$ Carballido, apud Duque Mesa, op. cit., p.85.

${ }^{225}$ Carballido, apud Duque Mesa, op. cit., pp. 85-86.

${ }^{226}$ A referência à União Soviética se faz em função de o termo localizar tempo e o contexto político em que Sano
} 
cênicos de Vakhtângov. Seki Sano pode representar, de certo modo, um dos depositários da herança viva de pelo menos 30 anos de pesquisa em teatro na Rússia, impressos nas figuras de seus três grandes mestres: Stanislavski, Meyerhold e Vahktangov, ainda que este último já tivesse morrido quando Sano chegou à Rússia. É bom lembrar que em seguida o mundo perderia também os dois gênios restantes do teatro russo: Stanislavski morreria em 1938 e Meyerhold seria executado pela polícia política de Stalin em 1940.

Num primeiro momento, conta Seki Sano, ele se dirigiu a Stanislavski, dizendo-lhe que queria estudar com ele, ao que o Mestre respondeu, inquirindo-o sobre "o que quer aprender de mim?”. “Direção de cena”, respondeu Sano. “Equivocou-se de porta, vá com Meyerhold: fim da entrevista!”. E Sano continua:

Fui com Meyerhold: "Vem do Japão? Que bom, fique aqui, pode aprender o que quiser, e a mim me ensinará por sua vez teatro clássico japonês”. Fiquei por cinco anos. Assistindo aos ensaios diários das obras clássicas meyerholdianas: A Floresta, O Inspetor Geral, O Magnífico Cornudo (maravilhosa!) ${ }^{227}$.

Perguntado sobre o estilo de Meyerhold, Seki Sano responde que era "tudo o contrário do que comumente se diz”. E, neste trecho, contém uma idéia particularmente revolucionária sobre as práticas dos dois grandes mestres russos, principalmente, se se tem em mente os rótulos que se costumam atribuir a um e outro, representando-os como dois caminhos antitéticos; e, que seriam por causa disso mesmo, inconciliáveis na arte. Que Meyerhold era considerado,

o protótipo do formalismo, e Stanislavski, o do sentimento. Seria exatamente o contrário. "Se não tem o que sentir, está perdido. A pura forma não basta”, dizia Meyerhold. A cada momento, citava Stanislavski como autoridade: isto me intrigava. Voltei a Stanislavski. Éramos uns dez que trabalhávamos num pequeno projeto de oficina. Da boca de Stanislavski ouvi muitas coisas, tudo o contrário de quanto se diz: "o só sentir não basta, há que projetar forma bela. Por aí caminhava o segredo: combinação da técnica de vivência com a de representação. (...) Daí, o que quis fazer Meyerhold, criar a ilusão e rompê-la, voltar o público à realidade, tirando-o da ficção; aí está o caminho de Brecht, que é um caminho eterno: o teatro deve ser teatral.e aí cabe a escola de vivência de Stanislavski ${ }^{228}$.

${ }^{227}$ Carballido, apud Duque Mesa, op. cit., p. 86.
${ }^{228}$ Carballido, apud Duque Mesa, op. cit., p. 86. 
Que Meyerhold foi considerado o filho rebelde da escola de Stanislavski, isso todo mundo sabe. Mas nessa altura dos anos 30, os grandes momentos de conflito e confronto entre os dois já tinham ficado para trás. O que estava em marcha nesse momento era não só o profundo respeito mútuo pela pesquisa de cada um como também uma espécie de mútua contaminação. Daí o costume de atribuir ao desenvolvimento do conceito de "ações físicas" de Stanislavski, em sua fase tardia, à influência de Meyerhold.

Segundo Seki Sano, “el estudio de Stanislavski nos conduce forzosamente a pisar el terreno de la psicología, del psicoanálisis, casi el terreno de Freud; en el sentido de que cualquier manifestación que hagamos está regida por la inconsciência”229. Com relação a Vakhtângov, Sano relata que ele tinha quase veneração por Meyerhold, "porque [ele, Meyerhold] sabía combinar ambas cosas” [forma e vivência]. “O caminho de Vakhtangov é o teatro teatral, vivencia, teatralidade, muito conteúdo, muita forma” ${ }^{\text {,30 }}$. Enfim, com esta entrevista, fica evidente a profunda influência de Meyerhold e Stanislavski na conformação da sensibilidade teatral de Seki Sano: “yo tengo mucha influencia de Myerhold”, (...) ...mi busqueda esencial es la vivencia”231.

A partir dessa aproximação da história de Seki Sano, de sua bem aventurada estada nos últimos anos com as duas figuras emblemáticas da inovação e da vanguarda teatral russa, pode-se inferir a idéia já mencionada anteriormente: a de que Seki Sano pode representar um ponto de convergência dessas duas vertentes estéticas, que conformaria no espírito do homem de teatro e futuro pedagogo o profundo senso de composição da cena a partir de sua visibilidade plástica aliada à verdade psicológica do trabalho de ator: "Qué busca en el fondo Stanislavski? La lógica de la conducta humana”.

Pois é este homem que chega à Colômbia em setembro de 1955.

Para corroborar esta idéia referente à importância da pedagogia teatral de Seki Sano no teatro colombiano, far-se-á referência a um dos poucos estudiosos do teatro colombiano que atentou para a envergadura da ação desse diretor. Em sua tese de doutorado, Baycroft

\footnotetext{
${ }^{229}$ Carballido, apud Duque Mesa, op. cit., p. 87.

${ }^{230}$ Carballido, 1976, pp.8-11, apud Duque Mesa, op. cit., p. 87.

${ }^{231}$ Carballido, 1976, pp.8-11 apud Duque Mesa, op. cit., p.88.
} 
faz a seguinte afirmação: "Seki Sano injetou um dinamismo no treinamento de ator na Colômbia, estabelecendo o primeiro programa de estudo baseado em um método científico” $^{\text {232 }}$. Entretanto, dá-se aqui o instigante caso de o autor não fazer nenhuma referência sobre a já comprovada influência de Meyerhold. Ele também teve acesso à mesma entrevista de Seki Sano concedida ao dramaturgo mexicano, Emilio Carballido, em 1976 (onde a explanação sobre o período de sua estada na Rússia é relatada); porque a cita a certa altura de seu trabalho. Entretanto, ele só fala de Stanislavski, como se apenas o mestre do "sentimento" tivesse exercido influência sobre o ilustre pedagogo teatral japonês.

Fausto Cabrera é outro homem de teatro que estudou com Seki Sano, e que, já em 1958, reconhecia o legado que a escola russa de Seki Sano representou para a Colombia, declarando que "su breve permanência em Bogotá dio origen al poderoso movimiento que hoy surge en todo el país”.

Em vista do exposto, parece evidente a importância da pedagogia teatral do diretor japonês, que por vias tortuosas, foi parar em 1955, na Colômbia recém saída da violência do "bogotaço", sob o governo de ditadura militar, para formar atores... de Teatro.

\section{Revista Mito}

Não é possível falar do Nuevo Teatro em Colômbia sem se referir ao papel relevante desempenhado pela revista Mito, principal veículo de difusão das idéias novas que afluíam de todos os lados ao país. Gonzalo Arcilla, Vázquez-Zawadzki, Maria Mercedes de Velasco, Carlos José Reis, e todos aqueles que abordaram o movimento fazem necessariamente, de um modo ou de outro, referência a ela; como, por exemplo, o fato de o primeiro artigo de Enrique Buenaventura ter sido publicado nela, registrando e documentando desde o início o esforço intelectual de um dos principais líderes do Nuevo Teatro.

\footnotetext{
${ }^{232}$ Tradução do original feita pela pesquisadora: "Seki Sano injected a dynamism into actor training in Colombia, establishing the first program of study based on a scientific method”. In: Baycroft, Bernard Kent. Brecht in Colômbia: the rise of the New Theatre. Tese de Doutorado, Stanford University, Janeiro de 1986, p.10.
} 
A revista foi fundada em 1955 por Jorge Gaitán Durán (1924-1962), publicada de forma irregular de 1955 a 1962, num total de 42 números. Sua tiragem era de cerca de 1.000 a 1.500 exemplares, bi-semestralmente. Esses dados constam no artigo precioso de Mar Estela Ortega González-Rubio ${ }^{233}$, que tem como projeto de pesquisa exatamente o aprofundamento sobre as "causas sócio-políticas e culturais que deram origem ao aparecimento"234 do grupo dessa revista. Ainda que de forma sumária, o interesse em sua descrição deve-se, primeiro, ao fato de ela ter preparado o ambiente para o surgimento do movimento teatral; e, segundo, ao fato de ter representado um ato de ruptura com o "campo cultural dominante" e oficial ao lançar seus princípios alinhados com a vertente vanguardista como seus próprios integrantes sugeriram na época, bem como posteriores análises de estudiosos. Mas fica em aberto a resposta sobre o modo como se deu esse vanguardismo literário colombiano tardio, a quase meio século de distância temporal daquele ocorrido na Europa, em cuja fonte inspiraram-se a totalidade dos países periféricos latino-americanos.

Se é verdade que a revista Mito é um marco do surgimento do movimento de vanguarda na literatura colombiana, convém considerá-la um dado importante para a compreensão de outro fenômeno correlato ao seu: a vanguarda teatral, expressa tanto na vertente experimental quanto na vertente política, ambas, por sua vez, experiências determinantes na configuração do Nuevo Teatro.

De volta então para mais algumas considerações sobre essa revista, falta denunciar junto com González-Rubio o paradoxo expresso no próprio nome do grupo, Mito, “na medida em que o país, mais que de ficções, necessitava de verdades, ou pelo menos, de abordagens mais objetivas da realidade violenta que se vivia nesses tempos”. A julgar pelas declarações de seus integrantes, o argumento era de que o mito era para melhor “desmitificar”. Assim, não aludiria à "reprodução ou continuação do corpo de mentiras que haviam sido impostas ao país”, mas, ao contrário, “relacionar-se-ia com o ato de fundar o

\footnotetext{
233 “El grupo ‘Mito’ y las Vanguardias en Colômbia”. In www.ucm.es/info/especulo/numero28/mitocol.html. 234 “....me queda el compromiso de realizar con mis estudiantes de literatura de la Universidad Pedagógica Nacional, una propuesta o proyecto de investigación que ahonde mucho más en las causas socio-políticas y culturales que originaron la aparición de este grupo abierto a las vanguardias...”.
} 
país, inaugurá-lo, abrí-lo, criá-lo, partindo do anti-mito, um relato poemático crítico da linguagem e da cultura.” 235

O dispositivo paradoxal utilizado no nome do grupo faz lembrar de passagem dispositivo similar de certos poetas da segunda metade do século XVIII, cujas obras continuaram resistindo à classificação literária, como bem observa Walter Benjamim. Ao abordar "o satanismo de um Rimbaud e de um Lautréamont como uma contrapartida da arte pela arte”, o ensaísta propõe "ignorar a fachada dessa tese” (a da arte pela arte), para encontrar "no interior [dessa arte] algo de aproveitável”. ${ }^{236}$ Para isso, recorre até a uma carta que Isidore Ducasse (1846-1870) escreveu a seu editor em 1869 para justificar a brutalidade da violência em sua obra e na qual se lia a seguinte passagem: "Naturalmente, exagerei um pouco o tom para introduzir algo de novo nessa literatura, que só canta o desespero para oprimir o leitor e fazer-lhe desejar o bem como remédio. Assim, em última análise, somente cantamos o bem, embora por um método mais filosófico e menos ingênuo que a velha escola...”. ${ }^{237}$ Ou seja, a tese é de que se canta o supra-sumo da violência, como se pode conferir em seu Cantos de Maldoror, para melhor combater a violência.

Da mesma forma, utiliza-se o nome "mito" contra a criação de mais mitos, insuflando-lhe uma "sinceridad robesperiana”"238, clareza, além de consciência e crítica da função do intelectual. A “recuperação da relação entre a vida e as palavras” era um dos objetivos que orientava a revista, segundo formulação publicada no editorial de seu primeiro número ${ }^{239}$. A atitude frente às palavras, de considerá-las “em situação”, tendia a transbordar o plano literário, criando situações verdadeiramente políticas na luta contra a ditadura de Rojas Pinilla, e, depois, contra a ineficiência dos governos posteriores. Considerar as palavras passíveis de serem "modificadas permanentemente pela historicidade das relações sócio-culturais”, revela-se assim um instrumento forte de luta e resistência contra tentativas de inssureição da mistificação.

Desse modo, o grupo Mito se determina como vanguardista e se contrapõe à tradição literária colombiana das gerações anteriores, cuja poética tendia ao

\footnotetext{
${ }^{235}$ GONZALEZ-RUBIO, op.cit., www.ucm.es/info/especulo/numero28/mitocol.html

236 "Surrealismo: último instantâneo da inteligência européia” In BENJAMIM, Walter. Obras escolhidas. Magia e técnica, arte e política. 7 ed. São Paulo: Brasiliense, 1994, p.30.

${ }^{237}$ Idem, Ibidem, p.31.

${ }^{238}$ González-Rubio, op. cit.

${ }^{239}$ Gonzalo Arcilla. Nuevo teatro en Colombia, p.22.
} 
“acartonamiento parnasiano”240, característica presente no conjunto de grupos e escolas literárias do final do século XIX e inícios do XX, tais como, o grupo “Centenario” (1910), o grupo de "Los Nuevos” (1930), "Piedra e Cielo" (1939) e o grupo “Cântico” ou "Los Quadernícolas” (meados dos anos 40).

Se há algum fio que ligue esse vanguardismo a algum poeta do passado, o único possível teria sido José Asunción Silva (1865-1896), cuja atitude honesta, fez dele um poeta comprometido com a realidade, de vê-la e denunciá-la, colocando-se como "poeta vidente" $^{241}$. Mas o que interessa afinal nessa descrição é uma informação importante que traz o comentário de Fernando Charry Lara sobre uma dessas escolas literárias:

"Los Nuevos" constitue, evidentemente, numa prolongação das tesis parnasianas. Ao mencionar este ponto é necessário dizer que eles não mantiveram, ao contrario do que se tem afirmado, o menor contato com os "ismos" do pós-primeira guerra, fontes indiscutíveis da "nueva" poesia, e menos que, superando seus programas, desembaraçaram-se deles $^{242}$.

Deixe-se em suspenso no momento esse dado que mais a frente será enfrentado.

Sobre essa revista, resta concluir que o seu surgimento representa enfim a luta da “intelectualidade burguesa”243 bogotana contra a ditadura militar, contra a arbitrariedade literária praticada em nome do nacionalismo e regionalismo e contra a "cultura resignada e conformista” das escolas anteriores, segundo interpretação de Gonzalo Arcilla e GonzálezRubio. Enfatizando uma "visão crítica a propósito das ilusões e fantasias” subjacentes ao racionalismo e cientificismo,

cuestiones fundamentales para Mito, como el fracaso de los sistemas, la paradoja y el absurdo, la desesperación y la angustia, el sentido del riesgo del individuo, y la incertidumbre absoluta de lo objetivo, encuentran un asidero filosófico y unas resonancias explicables en las ideas del existencialismo de Heidegger y Sartre, filosofías esenciales para el grupo $^{244}$.

\footnotetext{
${ }^{240}$ Segundo a expressão de Armando Romero (1985, p.22), citado por Ganzález-Rubio, op. cit.

${ }^{241}$ Ganzález-Rubio, op. cit

242 (1975, p.65), apud Ganzález-Rubio, op. cit.

243 Gonzalo Arcilla, p.22-23.

${ }^{244}$ Idem, Ibidem.
} 
Seu cosmopolitismo permitiu a publicação de autores estrangeiros, "introduzindo em Colômbia a discussão internacional para estar à altura dos tempos”. González-Rubio nota que:

Allí se publicaron de manera exclusiva, textos de Jorge Guillén, Vicente Alexaindre, Luis Cernuda, Carlos Drummond de Andrade, Carlos Fuentes, Juan Goytisolo, Luis Cardoza y Aragón, Octavio Paz. En su deseo de romper el provincianismo secular, de crear el anti-mito para sacar al país del atraso intelectual y social en que se encontraba, se abrieron al dialogo franco con el pensamiento occidental, a múltiples tendencias e influencias foráneas. Se privilegia, en cuanto a literatura extranjera, la francesa: Saint-John Perse, Paul Valery, Rimbaud, Jean Tardieu, Jean Paul Sartre; inglesa: Ezra Pound; alemana: Bertold Brecht, Gottfried Benn, Hegel, Heidegger; latinoamericana (sobre todo México y Argentina), con Octavio Paz y Jorge Luis Borges. En el erotismo de la poesía de Gaitán Durán se siente a Bataille y a Sade; el pensamiento germanizante en Eduardo Cote Lamus, la influencia china en los poemas de Arbeláez. Ansiosos de incluir a Colombia en la contemporaneidad del mundo, aceptan todas las utopías, sin importar las procedencias; como el vagabundo Maqroll, están abiertos a los vientos de todos los mares culturales.

E com essa longa citação, encerra-se a descrição resumida sobre a revista Mito, cuja importância na configuração do Nuevo Teatro será oportunamente retomada no desenvolvimento do trabalho.

\section{Precursores}

Afirmar que antes da movimentação teatral dos anos 50 não havia "una verdadera tradición teatral” na Colômbia, como fazem Mejía Duque ou Ricardo Camacho, para ficar apenas nestes, não ajuda a compreender o surpreendente desenvolvimento teatral num país situado na periferia. Ao longo de sua historia de vicissitudes, produto da condição de país colonizado, subjugado, e atrasado ${ }^{245}$, material e espiritualmente, como a maioria dos países latino-americanos, tem-se notícia de expressões teatrais em diversas ocasiões, ainda que pontuais, como tentativas de dramaturgias e de organizações teatrais, por espanhóis radicados na colônia e depois por crioulos. Embora o ponto de vista dos dois autores

\footnotetext{
${ }^{245}$ Ricardo Camacho, “La 'creación’ y la crisis de autores en el teatro nacional”, p.480.
} 
referidos acima parece considerar a atribuição de “atraso" da Colômbia em relação a uma suposta medida de civilização, na qual a Europa, numa visão eurocêntrica, representaria o topo, aonde os demais lutariam por alcançar; posiciona-se neste ponto em favor da crença de que este atraso se refere mais às dificuldades de elaboração de um projeto nacional adequado à sua história e cultura.

A beligerância da Colômbia, em meados do século XX, deveu-se a diversos fatores, entre os quais, o aguçamento de suas contradições fundantes em virtude da heterogeneidade histórica e cultural, que a levou à beira de um estado radical de anomia, expressa na violência da guerra civil, representada nas lutas camponesas e bipartidaristas. Foi a "ferro e fogo” que se forjou ao longo do século XIX uma idéia de nação e território, isto é, plasmada por meio de uma sucessão de confrontos civis, último dos quais teve lugar a Guerra dos mil dias, de 1899 a 1902, em conseqüência da qual, a Colômbia "foi amputada da porção territorial que passou a se chamar República do Panamá”. ${ }^{246}$

Será que isso tudo aconteceu sem que nada se fizesse no âmbito da produção imaterial? Não houve então nenhuma produção do espírito que, de um modo ou de outro, tocasse à gente do país emergente?

Se se quer compreender o real alcance da agitação cultural dos anos 50, convém dedicar certa atenção às obras de alguns precursores, sob o risco de perder de vista o fio que o Nuevo Teatro tenta recuperar não só da tradição teatral colonial como também daquela mais antiga e obscura da tradição pré-colombiana.

Em vista do longo processo histórico, do efeito profundo, duradouro e homogeneizante da Conquista e da Colônia espanhola, qualquer tentativa de perfurar essa “colonização cultural” por mais frágil que seja, acrescenta, contribui e faz diferença. Parafraseando ainda uma vez Antônio Cândido, “comparado aos grandes, o nosso teatro é pobre e fraco. Mas é ele, não outro, que nos exprime”. Como não se referir a um Enrique Osório ou a um Alvarez Lleras, a um Carlos Emilio Campos ou a um Luis Vargas Tejada (1802-1829), e ainda muitos outros que tentaram; porque, como diz Walter Benjamim todos os bens culturais “devem sua existência não somente ao esforço dos grandes gênios que os

\footnotetext{
${ }^{246}$ Enciclopédia Latinoamericana, p.320.
} 
criaram, como à corvéia anônima dos seus contemporâneos”. ${ }^{247}$ Se não havia espaço para se montar peças escritas por autores locais, nem por isso deixou-se de escrevê-las. E escreveu-se como foi possível escrever em cada época.

Luis Vargas Tejada, por exemplo, é um dos exemplo deste esforço de escrita dramática do século XIX. Ele "teve uma vida meteórica [...], aos 17 anos apresenta sua primeira obra teatral, Aquimín, além de obras de temas indígenas como Saquezazipa, Sugamuxi e a tragédia Witikindo. [...] Mas sua obra mais representativa é Las Convulsiones", que, mais do que um tema político, tratava-se de uma "crônica sarcástica dos costumes urbanos de seu tempo”, muito inspirada em Goldoni e Maquiavel. O sainete teve sua estréia três meses antes do atentado frustrado de Tejada contra Bolívar. Tejada era muito ativo na atividade política, por isso muito próximo a Santander e ao Libertador. Quando estes dois se separam, Tejada toma o partido de Santander, atentando contra a vida de Bolívar, depois do qual, desaparece aos 27 anos de idade ${ }^{248}$.

É nesse sentido também que Carlos José Reyes evoca e reconhece o valor dos feitos dramatúrgicos da primeira metade do século XX. Escreve-se muito, ainda que se encene muito pouco, salvo tentativas pontuais de montagens teatrais, empreendidas na maior parte pelos próprios autores dramaturgos. Nessa perspectiva, destacam-se dois nomes "que contribuíram com suas obras e sua atividade constante” de formação de grupos e de atores, "de modo a manter o interesse pelo teatro e dar os primeiros passos na estabilização de seu ofício”. ${ }^{249}$ Tratam-se justamente de Antonio Alvarez Lleras e Luis Enrique Osório; o primeiro foi criador da Companhia Renascimento, e o segundo, além de "comediógrafo prolífico”, foi diretor da Companhia Bogotana de Comédias e construtor de um teatro em $1952 .^{250}$

O teatro de Álvarez Lleras “pertencia a chamada 'alta comédia’ com indubitáveis influências de autores como Echegaray ou Benavente”, além dos dramas de Ibsen, segundo

\footnotetext{
247 “Sobre o conceito de história”. In Magia e técnica, arte e política, op. cit., p. 225.

${ }^{248}$ Duque Mesa, Fernando; Prada prada, Jorge. Santiago García: El Teatro como Coraje. Bogotá, Investigación Teatral Ed., 2004, p.66.

${ }^{249}$ REYES, José Carlos. “1955-1987: um movimiento plural e creciente” In Escenarios de dos mundos.p.315.

${ }^{250}$ REYES, José Carlos. Op. cit. , p.315.
} 
Carlos José Reyes ${ }^{251}$. Enquanto Luis Enrique Osório assume uma posição claramente nacionalista.

É verdade que esta produção teatral dos anos quarenta passava por um aprofundamento de sua crise depois de sofrer forte desgaste de seu "modelo" ou "receita”. A se pautar nas palavras de Beatriz Rizk, fica-se sabendo que este teatro dos anos quarenta e cinqüenta, que precede diretamente ao de Enrique Buenaventura e Santiago Garcia,

...caracterizava-se por ser predominantemente comercial, ligeiro, sentimental, por uma atuação estereotipada, infestado de "receitas", por uma relação geralmente paternalista, condescendente com o público e ... por uma atitude algo paroquial frente à vida e ao teatro, devido ao isolamento do país; era pois grandemente frívolo, tendia mais a divertir ao público que fazê-lo refletir ${ }^{252}$.

Tratava-se, portanto, de um teatro de pura diversão que abordava as particularidades nacionais de forma pitoresca por meio da “comédia de costumes” (costumbrismo), a anedota e o episódio. Não se poderia dizer tratar-se de "teatro burguês" do tipo vigente na Europa dos séculos XVIII e XIX, magistralmente analisado por Peter Szondi, ${ }^{253}$ mas poderse-ia sim afirmar sua forte influência sobre o teatro das ex-colônias, se se considerar as descrições feita por Rizk, cuja citação a seguir poderá desvendar essa prática:

...continuava-se utilizando, por exemplo, os telões como recursos cenográficos, que apresentavam a vantagem adicional de poder serem utilizados em outras obras, isto é, havia telões para cenas no bosque, para cenas de interior, para cenas de jardim, no balcão etc.; o "ponto" lembrava o texto aos atores, o aparte era elemento dramatúrgico muito defendido, o "caco" permitia aos atores se consagrarem a fazer rir ao público com um comentário oportuno, ainda que não fizesse parte do argumento; recursos vulgares todos estes, que tinham já quase dois séculos de existência e não havia sido até então quase questionados ${ }^{254}$.

Ora, esse quadro descrito por Rizk é o mesmo traçado pelo estudioso francês. A estrutura das companhias estratificadas em classes: primeiro ator, primeira atriz, as divas, os monstros sagrados, a auto-exibição dos atores sem o menor pudor ao público. As regras obedecidas à risca, tais como, não se pode dar as costas ao público, o esplendor do figurino,

\footnotetext{
${ }^{251}$ REYES, José Carlos. Op. cit. , p.315.

252 “La obra de Enrique Buenaventura”. In Separata Dramaturgica. Bogotá, Escuela Nacional de Arte Dramático, Cocultura, 1996, p.12.

${ }^{253}$ Teoria do drama burguês [Século XVIII]. São Paulo: Cosac \& Naify, 2004.

254 “La obra de Enrique Buenaventura”. In Separata Dramaturgica, op. cit., p.13.
} 
muitas vezes sem nenhuma relação com o personagem, a impostação da voz e a declamação, a linguagem culta, tornando impossível a fala do criado em cena, por que seria inverossímel o criado falar de modo culto, e sua linguagem vulgar não era permitida em cena. O quadro é similar, salvo um detalhe fundamental: na Europa, o público deste teatro, era constituído pelo "genuíno" burguês no auge de sua consolidação como classe revolucionária e vencedora de uma determinada ordem no mundo; enquanto nas excolônias latino-americanas, a elite crioula era uma classe recém-surgida, formada na luta não contra o nobre, mas contra conquistasores e colonizadores, o que por si só já redesenha uma outra realidade.

\section{O teatro de Alvarez Lheras (1892-1956)}

Antônio Alvarez Lheras, dramaturgo, diplomático e dentista, desenvolve uma escritura dramática de índole literária, cultivando a um só tempo um teatro de cunho psicológico e social. ${ }^{255}$ Teve influência de correntes espanholas e francesas como a "alta comédia” e o melodrama. ${ }^{256}$ Ainda jovem, lança sua primeira obra Víboras sociais, que fez muito sucesso, gerando uma expectativa ao redor do autor como grande promessa literária. Embora não seja de suas melhores obras, Víboras é um bom exemplo de seu "drama de tesis”, já que a “inclinação social e o pessimismo refletidos nessa obra iriam reaparecer em várias de suas peças posteriores. ${ }^{257}$ Escreveria em seguida, Alma joven (1911) e El fuego extraño (1912); Como los muertos (1916), é o primeiro de seus dois dramas psicológicos; Los mercenários (1924); Alma de ahora (1945); El zarpazo (1946); El virrey Solís (1947).

Para Lyday, “El Zarpazo é claramente o melhor dos dramas psicológicos de Alvarez Lheras e merecidamente é catalogada como uma de suas melhores obras”. ${ }^{258}$ Além disso, é considerada um dos primeiros exemplares do teatro realista hispanoamericano.

Com relação El virrey Solís, trata-se de um drama histórico que relata a vida de José Solís e de Marichuela, sua amante. Nesta última peça do dramaturgo, Solís, a caracterização

\footnotetext{
${ }^{255}$ César Aira, Dicionário de Autores Latinoamericanos, p.29.

256 José Carlos Reyes, “Prólogo”. In Materiales..., p. 25.

${ }^{257}$ Leon F. Lyday. “Antonio Alvarez Lheras y su teatro”. In Materiales..., p. 233.

${ }^{258}$ Leon F. Lyday. “Antonio Alvarez Lheras y su teatro”. In Materiales..., p. 241.
} 
dos personagens é significativamente superior às outras peças do dramaturgo, na análise de Lyday, para quem “os protagonistas ... são retratados habilmente e com uma cuidadosa mescla de história e lenda, e os numerosos personagens menores também recebem esmerada atenção". ${ }^{259}$ Esta obra foi muito aplaudida. , mesmo sustentando uma visão tradicional de drama como a maioria de sua produção, consolidando assim seu interesse especial no teatro de idéias ou de missão social.

Alvarez Lheras, portanto, ainda que em nenhum forma é um grande dramaturgo, foi um dos proeminentes comediógrafos hispanoamericanos de começos do século e deve ser catalogado entre os mais altos expoentes do teatrocolombiano. Sua influencia sobre outros dramaturgos foi também significativa, e el chegou a ser reputado como o pai do teatro moderno em Colômbia, posição reconhecida de igual maneira tanto por dramáticos quanto por críticos.

Com relação a ser considerado como marco do advento do teatro moderno parece não haver consenso entre historiadores. Ainda mais se se tiver em mente que a principal característica do teatro moderno nos países periféricos está relacionada à sua profissionalização, o que na Colômbia só vai acontecer em meados dos anos 50, depois do magistério apressado de Seki Sano, associado a uma produção tearal que começa a criar certa regularidade. Mas se ele não pode ser considerado como marco desse teatro moderno colombiano, foi fundamental no momento imediatamente anterior, como um preparador dos caminhos, sem o qual, certamente a historia do teatro colombiano teria sido outra.

\section{O teatro de Luis Enrique Osório (1896-1966)}

Depois de Alvarez Lheras, quem mais se destaca na literatura dramática é Luis Enrique Osório "por sintetizar em sua obra os problemas mais palpitantes que afetaram e continuam afetando à nação colombiana em seu processo democrático”. Enrique Osório, um homem “inquieto, de temperamento nervoso e vivaz, de vida dinâmica, (...) teve como

\footnotetext{
${ }^{259}$ Análise presente em outro artigo de Leon F. Lyday, "History and Legend” in El Virrey Solís of Antonio Alvarez Lheras, citado por Leon F. Lyday em “Antonio Alvarez Lheras..., p.243.
} 
grande meta ser representantivo de sua geração." ${ }^{260}$ Conheceu a muitos escritores contemporâneos em suas viagens ao estrangeiro: Pirandello, Bernard Shaw, O’neill; Benavente. De múltipla produção literária, o autor tratou com igual facilidade aos mais diversos gêneros tais como: o ensaio, artigo de jornal, novela conto etc, porém é "no drama que se revela mais plenamente e no qual se define melhor no papel duplo de homem e escritor”, segundo as afirmações de Barrera. Sua obra teatral inclui mais de 40 peças, algumas das quais continuam inéditas. “A temática delas cobre toda uma gama que abarca a sátira política e social, a análise dos problemas nacionais colombianos, os costumes e o folklore crioullo, o humor e a sátira de tom lligeiro, e outros temas diversos de assunto histórico, religioso ou psicológico." 261 Escreve entre outros títulos Al amor de los escombros (1920); Sed de justicia (1921); El iluminado (1929); El doctor Manzanillo (1943); Manzanillo no poder (1944). Estas últimas são peças de “uma mordacidade política em que o protagonista é um demagogo que busca nos cofres do Estado seu único meio de subsistência”262. Barrera mapeia influências literárias exercidas sobre Enrique Osório de escritores tais como o próprio Alvarez Lheras, o dramaturgo espanhol Jacinto Benavente, os franceses Marcel Pagnol, depois Denis Amiel e Jean Jacques Bernard da Escola do Silêncio, "que indicava que sob as palavras, a emotividade dos gestos e das pausas era por sua vez um novo e natural sistema de expressão”. Somado a este, Henri L. Lenormand, fundador da escola psicanalítica denominada 'La Subconsciencia', sob a influência de Freud. Nessa linha psicológica constam, por exemplo, Los criadores, Tragédia íntima e El hombre que hacia soñar. Há outro ciclo de peças do autor inspiradas na violência que assolou o país nos anos 50, tais como Nube de abril y Toque de queda (1948); iAhí sos camisón rosao! (1949); Si, mi teniente (1953) e Pájaros grises (1961). Barrera chama atenção especialmente para um grupo de peças, cujas representações buscavam dar forma a distintas preocupações, predisposições internas ou ideológicas do autor como por exemplo El Iluminado, em que seu liberalismo ganharia maior corpo; ou o sainete ${ }^{263}$ Pájaros Grises,

\footnotetext{
${ }^{260}$ Ernesto M. Barrera. “Algunos aspectos en el arte dramático de Luis Enrique Osório”. In Materiales..., p.263.

${ }^{261}$ Ernesto M. Barrera. “Algunos aspectos...”, op. cit. p. 264.

${ }^{262}$ Ernesto M. Barrera. “Algunos aspectos...”, op. cit. p. 264.

${ }^{263} \mathrm{O}$ sainete foi uma modalidade teatral muito em voga no período pré e pós-independência das colônias do cone sul da América Latina. Conforme dita a tradição, trata-se de "uma peça breve, jocosa, que reflete as atividades cotidianas do povo”. Segundo Túlio Carella, essa forma tem a sua origem mais longíqua na
} 
no qual o realismo seria mais explorado; ou ainda Bombas a domicilio, em que foi ensaiada uma “comédia de equívocos” a la Aristófanes; além de peças de comédia de costumes como a Adentro los de corrosca e El cantar de la tierra, cujas tentativas referem-se à construção "de tipos populares e da cor local, criticando-se os costumes e as interrelações da sociedade colombiana.",264

Apropriando-se de praticamente todo tipo de forma teatral que tivesse notícia, Enrique Osório pode ser considerado um verdadeiro precursor das incessantes buscas, combinações e experimentos que caracterizariam o Nuevo Teatro da geração seguinte. Ainda conforme o artigo de Barrera, suas obras participam tanto da farsa e da comédia satírica, quanto do gênero grotesco, além de lidar com a "alta comédia”: o sainete, a “comédia de enredos”, a farsa, o melodrama, a comédia alta e o entremés ${ }^{265}$. Nenhuma tragédia se encontra nesse conjunto e, com relação ao “drama”, apenas um par delas. Em suas obras de costume, exaltam-se poeticamente as virtudes do campo colombiano, o belo de suas aldeias em um tom de "romantismo extemporãneo"; e, às vezes, atacam-se mordazmente os vícios da cidade. Se se convém indicar algum dado que o distinga fundamentalmente da experiência ulterior, pode-se lembrar do fato de que Enrique Osório ainda está preso tanto quanto seu contemporãneo Alvarez Lheras, aos valores e à visão de mundo do século XIX, tal como ele se deu nessa região periférica do globo, vinculado venalmente ao pensamento francês. Dentro desse quadro, ele realiza também, com relação ao modo de produção de suas obras, o perfil do dramaturgo fechado em seu escritório em contraste com o movimento dos coletivos teatrais e das criações coletivas das décadas seguintes, sem que com isso desapareça na região a figura clássica do escritor dramático evidentemente.

Enfim, para finalizar com as palavras daquele em que se baseou a maior parte das informações expressas nesse ponto sobre esta personalidade singular da literatura

tradição dos mimos gregos e da atelana romana. Ao aportar na América via Espanha, o sainete vai ser logo assimilado com naturalidade pela região, recebendo acréscimos de novos acentos, rebeldes ou queijosos, desafiantes, líricos, angustiados e oprimidos, forjando aos poucos o sainete crioulo que vai mais longe ainda do que seu modelo estrangeiro. Além disso, introduz mudanças de variados elementos estéticos, acabando por transformar sua fisionomia num exemplo de tragicomédia. Para maior aprofundamento sobre esta forma teatral ver: Túlio Carella, El Sainete, Buenos Aires: Centro Editor de América Latina, 1967.

${ }^{264}$ Ernesto M. Barrera. “Algunos aspectos...”, op. cit. p. 268.

${ }^{265}$ Ernesto M. Barrera. “Algunos aspectos...”, op. cit. p. 268. 
colombiana, evoque-se o seguinte trecho: "o trabalho de Osório como orientador do teatro nacional de seu país é importante e digna de encômio. Neste sentido, o bogotano é uma figura expecional no panorama cultural colombiano dos últimos anos”. 266

\section{O Teatro Moderno na Colômbia}

Pablo Azcárate ${ }^{267}$ (1978) toma o ano de 1955 como data inicial da primeira etapa do processo do Nuevo Teatro. Gonzalo Arcila ${ }^{268}$ (1983), por sua vez, evoca o Festival Internacional de Teatro de 1957, na cidade de Bogotá, como marco referencial inicial desse processo. Já Eduardo Camacho Guizado ${ }^{269}$ (1977) evoca esse mesmo festival como marco do surgimento não do Nuevo Teatro, mas do Teatro Moderno no país; enquanto Eduardo Gómez $^{270}$ (1978) já associa o surgimento do teatro moderno na Colômbia com a chegada do professor e diretor de teatro japonês, Seki Sano. Por outro lado, Fernando González Cajiao $^{271}$ (1986) ao se referir a esse momento de revigoramento do teatro colombiano na década de 50 (do séc.XX), prefere denominá-lo de teatro experimental.

Está dada neste parágrafo uma pequena amostra da problemática com relação à terminologia no âmbito da arte em geral e do teatro em particular. Isto apenas para citar alguns dentre os inúmeros estudiosos locais que se debruçaram sobre a experiência teatral da Colômbia, sem nem sequer abordar no momento a lista de estudiosos estrangeiros que também não é coisa de se menosprezar. A atenção dada a essa experiência colombiana por estudiosos locais e estrangeiros também é digna de nota. Com ou sem exageros, ela comprova a relevândia do fenômeno teatral colombiano. Trata-se de uma agitação cultural sem precedentes na historia da Colômbia e da América Latina, cujos desdobramentos se fazem sentir até os dias atuais.

Essa pequena enumeração serve para demonstrar ainda as diversas interpretações que essa agitação cultural e teatral na Colômbia dos anos 50 provocou. Cada autor

\footnotetext{
266266 Ernesto M. Barrera. “Algunos aspectos...”, op. cit. p. 272.

267 “El Nuevo Teatro y la CCT” In: Materiales para una historia del teatro em Colômbia, 1978, p.

${ }^{268}$ Nuevo Teatro en Colômbia, 1983, p.16.

${ }^{269}$ Sobre la literatura colombiana e hispanoamericana, 1977, p.121.

270 “Notas sobre la iniciacion del teatro moderno em Colômbia” In Materiales para una historia del teatro en Colômbia, 1978, p. 361.

${ }^{271}$ Historia del Teatro en Colômbia, 1986, p. 275.
} 
estabelece seus próprios critérios de análise e definição, cada qual com sua abordagem distinta, ainda que a maioria esteja relativamente afinada com critérios europeus de análise e classificação. De qualquer forma, se não há consenso com relação à nomenclatura, é consenso a percepção de que algo de muito novo acontece nessa década de cinqüenta em diante, em termos teatrais e culturais. Ao enumerar estas percepções, contrapondo-as, confrontando datas e interpretações, não se pretende perseguir “certezas” cronológicas, ou marcos precisos, nem uma evolução histórica linear, mas apenas tentar situar minimamente no tempo os fatos mais importantes que desencadearam a formação do Nuevo Teatro na Colômbia. Nessa enumeração acima, percebe-se claramente que todos os autores estão se referindo ao mesmo momento de irrupção teatral no país, isto é, meados da década de 50. Pode-se então a partir destes três conceitos abordados acima aprofundar a compreensão tanto dos próprios conceitos quanto do período em que surgiram na América Latina: teatro moderno, teatro experimental e nuevo teatro.

\section{Teatro Moderno (no Brasil)}

Partindo da acepção de teatro moderno como entendido por Iná Camargo Costa, tem-se o seguinte:

O conceito de teatro moderno compreende o processo histórico desencadeado pela crise da forma do drama através da progressiva adoção de recursos próprios dos gêneros lírico e épico que culminou com o aparecimento de uma nova forma de dramaturgia - o teatro épico ${ }^{272}$.

Costa desvenda de forma clara nesse artigo “as razões do mal-estar”, a que ela mesma se referiu antes, provocada pela apropriação da expressão "teatro moderno" no Brasil. Isso se deve ao fato de a expressão designar particularmente um processo de transformação concreta da realidade social européia (grifo nosso) de fins do século XIX. Quando se começa a usar o termo no Brasil, em meados da década de 50, havia já quinze anos que tivera início o “combate à sua expressão máxima”, isto é, ao teatro épico, nos países que tendo vivido o processo lhe deram origem ${ }^{273}$.

\footnotetext{
${ }^{272}$ Cf. Sinta o drama, 1998, p.14.

${ }^{273}$ Ibidem, p.34.
} 
No quadro do teatro europeu, evidencia-se em fins do século XIX a crise do drama clássico burguês $^{274}$. Seguindo a linha de análise desenvolvida por Peter Szondi (2001), a crise da forma do drama ${ }^{275}$ abriu espaço para o advento que ele chamou de "drama moderno”. A transição para esta forma teatral foi identificada principalmente na criação de dramaturgos como Ibsen, Tchékhov, Strindberg, Maeterlinck e Hauptmann, cujas peças teatrais “colocavam em questão”, cada um a seu modo, os postulados da forma dramática clássica, provocando sua crise. Essa crise, isto é, o questionamento das leis básicas da forma dramática - a unidade de ação, lugar e tempo -, foi conseqüência da necessidade imperiosa de tratar em cena de novos conteúdos, num momento em que estes conteúdos ainda não haviam encontrado sua forma correspondente. A crise do drama clássico, portanto, caracteriza-se por essa contradição: novos conteúdos conformados no velho "princípio formal do drama”276. O Naturalismo teria sido nesse sentido a primeira expressão dessa contradição, surgido antes como uma das "tentativas de salvamento" do drama que de "solução" da crise, dada a propensão conservadora de seus "dramas sociais”277. Por outro lado, seguindo ainda a linha de raciocínio de Szondi, o Expressionismo teria sido considerado assim a primeira tentativa de "solução”278, sendo o Teatro épico além de "um capítulo entre outros do drama moderno”,279, a forma utilizada

\footnotetext{
${ }^{274}$ Peter Szondi chama de “drama clássico burguês” a produção teatral surgida no Renascimento e no Classicismo, no período da época moderna, no qual o “diálogo”, talvez pela primeira vez na história do teatro, torna-se o único componente da textura dramática; distinguindo-o, desta forma, tanto da tragédia antiga como da peça religiosa medieval, tanto do teatro mundano barroco como da peça histórica de Shakespeare (SZONDI, 2001, p. 30).

${ }^{275}$ Anatol Rosenfeld expõe de forma clara o conceito de drama puro (que coincide com o conceito de drama clássico burguês de Szondi). Resumidamente, na forma dramática, é exigido o desenvolvimento autônomo dos acontecimentos, sem intervenção de qualquer mediador, ou seja, o mecanismo dramático move-se sozinho, de modo que um encadeamento causal rigoroso é imposto, cada cena sendo a causa da próxima e esta sendo o efeito da anterior. Desta forma, “o futuro é desconhecido, brota do evolver atual da ação que, em cada apresentação, se origina pela primeira vez, e avança ininterruptamente num tempo linear e sucessivo como o tempo empírico da realidade, num mesmo espaço fechado. (...) Além das três unidades de ação, lugar e tempo, o diálogo é constitutivo do drama. É por meio dele que são contrapostas as vontades, ou seja, as manifestações de atitudes contrárias dos sujeitos, autônomos, que produzem o conflito, dando origem por sua vez ao evolver da ação dramática. O diálogo move a ação através da dialética de afirmação e réplicas, através do entrechoque das intenções” (ROSENFELD, 1965, p.22-24).

${ }^{276}$ Fátima Antunes da Silva, Manifestações Contemporâneas do teatro político, 2002, p.5.

277 Peter Szondi, Teoria do drama moderno, p.

${ }^{278}$ Ibidem, p.123.

${ }^{279}$ Cf. Costa, op. cit., p.15.
} 
“como critério de análise da dramaturgia do século XX"280, em virtude de representar em certo sentido uma das propostas formas mais bem acabadas de solução dessa crise.

Mas em que consistiam afinal esses “conteúdos novos” nas sociedades européias? Vale a pena citar a enumeração destes eventos selecionados por Costa:

O terreno em que a figura do indivíduo prosperou foi o do capitalismo concorrencial, cujo apogeu se verificou na década de 60 [do século XIX]. Dois fatos - ligados, mas não imediatamente - indicaram que esta fase estava em vias de superação: em 1871 a Europa teve oportunidade de viver, ainda que por pouco tempo em escala municipal, a Comuna de Paris, ou a experiência daquele "espectro" que rondava segundo o Manifesto de Marx e Engels; e, em 1873, o "crack" da Bolsa da Alemanha anunciava à burguesia a necessidade de impor alguma disciplina à "livre manifestação do eu" no jogo dos negócios. A derrota sangrenta do proletariado parisiense não impediu o ascenso rápido e continuado de sua organização. Esta acaba assumindo tais proporções que governos burgueses e a Igreja Católica começam a desenvolver estratégias de neutralização do ímpeto da classe operária (a Rerum Novarum é de 1891). No plano dos negócios, uma das saídas para os problemas da "livre concorrência" foi a concentração da "livre iniciativa" em poucas mãos, com o seu corolário, a fusão entre capital industrial e bancário que Hilferding chamou de capital financeiro. Em 1900 o processo já estava plenamente configurado e até economistas de observância burguesa o chamavam por imperialismo ${ }^{281}$.

São estes parte dos novos eventos; "a experiência social dessas realidades é o novo conteúdo que a forma do drama já não tinha como configurar”. A necessidade de “dar voz no teatro à classe operária que começava a conquistar espaço na cena política fez com que o drama começasse a narrar e o drama deu o primeiro passo em direção ao teatro épico”282.

Dessa forma, ainda seguindo de perto o raciocínio de Costa, vale a pena mencionar a seguinte idéia como aquilo que constitui o pressuposto fundamental do teatro épico:

se Lukács demonstrou que a experiência histórica da passagem do indivíduo para o individualismo teve como resultado a crise do drama, podemos afirmar, com apoio em Anatol Rosenfeld, que a solução dessa crise pelo teatro épico é resultado de uma nova experiência em que $o$ centro não está mais no indivíduo, mas no complexo das relações sociais $^{283}$.

\footnotetext{
280 Ibidem, p.15.

${ }^{281}$ Ibidem, p.19.

282 Ibidem, p.20.

${ }^{283}$ Ibidem, p.18.
} 
Já não se tratava da problemática do indivíduo, existencial ou psicológica, mas do conjunto de relações e interrelações que, com base na definição de Marx, conformam o indivíduo, ou seja, a idéia segundo a qual, "o modo de produção da vida material condiciona o processo em geral de vida social, político e espiritual. Não é a consciência dos homens que determina o seu ser, mas, ao contrário, é o seu ser social que determina a consciência”. 284

Essa pequena digressão se inscreve na tentativa de compreender o contexto europeu no qual surgiu a expressão “drama moderno”, um conceito europeu forjado também por pesquisadores europeus (Lukács, Szondi) para dar conta daquelas novas manifestações teatrais européias. Transplantada para o Brasil cinqüenta anos mais tarde, numa realidade de país colonizado e situado na "periferia do capitalismo”, a expressão gera mal-entendidos além de soar um tanto “deslocada”. Costa também mostra apoiada em trabalhos como o de Roberto Schwarz em que consiste este “deslocamento”. Uma forma de amenizar esse choque do transplante foi a adoção por Costa da expressão "teatro moderno" ao invés de “drama moderno", tendo em vista o fato de sequer ter tido por aqui a etapa do “capitalismo concorrencial”, no seio do qual "floreceu” o indivíduo, sujeito do drama clássico, dos séculos XVIII e XIX.

Chame-se a atenção, contudo, para o fato de que essas observações não significam uma espécie de lamentação ou de desejo inconfessável de querer ser a "Europa”, como faz Sarmiento encantado pelos Estados Unidos (“Sejamos a América!”), mas simplesmente de “constatação" dos fatos como provavelmente ocorreram. Não se parte do pressuposto aqui de que o desenvolvimento natural da cultura brasileira ou latino-americana será possível apenas quando se tiver alcançado formas artísticas européias, mas, ao contrário, será possível apenas ao se voltar para a observação da própria matéria-prima, a saber, a realidade da produção material da vida local e concreta.

Feito este parêntese, retorne-se para as formas que o "teatro moderno" assumiu no Brasil. Segundo Costa, a produção do teatro moderno no país é resultado dos primeiros sinais de recuperação econômica que a estratégia de retomada do crescimento impunha, expressa na política desenvolvimentista, de “substituição de importações”, imposta pelo

\footnotetext{
${ }^{284}$ Karl Marx, “Prefácio” de Para a Crítica da Economia Política. São Paulo, Abril Cultural, 1982, p.25.
} 
capitalismo tardio, o que significa, "nos estreitos limites da produção cultural, a proliferação de uma burguesia com anseios cosmopolitas em condições de patrocinar (financiando e consumindo) um teatro de "padrão internacional”. ${ }^{285}$ E o TBC (Teatro Brasileito de Comédia) seria a concretização desse desejo. Mas, como lembra ainda Costa, "teatro" nos seguintes termos: "primeiro, enquanto forma desvinculada de seus pressupostos sociais e, segundo, enquanto prática regressiva nos próprios países de origem”. E acrescenta finalmente que “o caráter” do teatro moderno no Brasil “é semelhante ao dos grandes centros, por razões opostas - aqui por falta e lá por 'excesso' de experiência com o movimento operário, sempre sem esquecer que as nossas relações de base permanecem inalteradas”. 286

A longa referência e a longa citação do trabalho de Iná Camargo Costa se justificam por duas razões: primeiro em virtude da seriedade e lucidez da análise empreendida pela pesquisadora tanto na sua busca da compreensão do lugar ocupado pelo teatro moderno europeu, quanto do seu “desconcerto” ao ser importado pelo Brasil. A revisão da história teatral moderna brasileira, apoiada no método dialético, é capaz de lançar compreensões mais aprofundadas dessa experiência, em função de não se contentar aí em meras descrições, mas em detectar as suas contradições mais sutis. E finalmente, porque a compreensão desta experiência do TBC e do teatro moderno no Brasil, que nos é próxima, facilitará a compreensão da experiência do teatro moderno na Colômbia, uma vez que, em linhas gerais, tratam-se de experiências semelhantes, confirmando assim a similitude entre os países latino-americanos, não só com relação à história comum de países colonizados e selvagemente explorados, mas também no que se refere à sua vida cultural e seus processos de apropriação da cultura estrangeira.

Como já referido acima, em virtude das semelhanças históricas e culturais entre os países, este "mal-estar" com relação ao uso do conceito "teatro moderno", aplicado às experiências teatrais “inovadoras” no Brasil, também é detectado ao se estudar o teatro colombiano.

Também neste país, o “teatro moderno” é produto do processo de “modernização da cultura” empreendida, como aqui, pela elite empresarial nascente, interessada numa espécie

\footnotetext{
285 Ibidem, p.35.

${ }^{286}$ Ibidem, p.35.
} 
de atualização da produção cultural, importando o que se fazia na Europa e nos Estados Unidos, do pós-guerra, e não, como diz Costa, resultado de alguma pressão de “conteúdo novo”, nascido com a "experiência concreta do movimento operário".

E é nesse sentido, deslindado por Costa, que se pode falar do advento do teatro moderno na Colômbia. Com pequenos descompassos de ordem temporal, uns anos a mais ou a menos, e de certas peculiaridades de especificidades nacionais, seguem quase simultaneamente entre os países da região as experiências históricas de maior vulto como a passagem do genocídio da conquista para a exploração colonial, dos ciclos econômicos impostos pelas demandas dos colonizadores, das lutas pela independência ao ascenso de elites crioulas locais, e enfim, do surto industrial no transcorrer do século XX, durante o qual, e desde ainda finais do século XIX, foi gerada uma política bipartidária assentada em dois grandes adversários: de um lado a ala dos industriais progressistas - partido liberal, e, de outro, a oligarquia latifundiária - partido conservador e, portanto, supostamente portador de uma "tradição".

No caso da Colômbia, cabe salientar que a agitação teatral que se conheceu nos anos 50 se deu em meio a uma ditadura resultante da luta encarniçada entre os dois partidos políticos locais, período que ficou conhecido como os “anos de la violência”, já sucintamente tratados no capítulo dois do presente trabalho.

\section{Teatro Moderno na Colômbia}

Em vista disso, do contexto dessa violência político-econômica, como entender o surgimento de um movimento de teatro dessa magnitude? Como articular as distintas explicações sobre essa movimentação teatral de meados da década de 50 ? "Nuevo teatro”, “teatro moderno” e "teatro experimental” como operação voltada para a compreensão do “nuevo teatro"?

Como se viu no início deste capítulo, os estudiosos do teatro colombiano referemse à como. Junto com Camacho Guizado e Eduardo Gómez, parte-se do pressuposto de que a agitação teatral tenha sido a forma que os países dependentes encontraram para se apropriar das experiências deste período é mesmo teatro moderno, entendido a partir dos apontamentos de Iná Camargo Costa. 
Para Baycroft, "o Nuevo Teatro e a idade moderna do teatro começaram simultaneamente” (p.10). As denominações teatro experimental e nuevo teatro seriam modalidades diferentes deste teatro moderno, as quais reproduziriam de certo modo o debate entre arte e política que se via no âmbito da produção teatral e artística das principais capitais dos países centrais. Os grupos teatrais ligados a estas vertentes acabariam por se vincular mais tarde ao movimento do teatro independente.

As múltiplas considerações sobre o que determinaria o marco desse advento, vai da chegada do professor japonês Seki Sano à realização do Primeiro Festival Internacional de Teatro. Mas há outros que retrocedem ainda mais no tempo, como o ciscussões

Nesse sentido, Gonzalo Arcila tem razão ao assinalar a importância da realização em 1957 do Primeiro Festival Internacional de Bogotá, uma vez que a visibilidade alcançada pelo evento teve repercussões inauditas e gerou novos desdobramentos para o desenvolvimento do teatro colombiano. Mas a maioria dos historiadores concorda que o fato fundamental que marcaria para sempre este salto foi a contratação do professor japonês Seki Sano, que chegou em 1955, em Bogotá. Na página 361, no artigo citado de Eduardo Gómez, na obra "Materiales...” encontra-se uma referência a este respeito. Ele considera como sendo o marco do início do teatro moderno em Colombia a chegada do diretor japonês Seki Sano a Colombia; e Enrique Buenanventua como um dos principais iniciadores do teatro moderno em Colômbia.

O que distingue, por outro lado, a experiência do advento do teatro moderno na Colômbia é o fato de que num curto espaço de cerca de 15 anos, invertendo a lógica de sentido, foi o conteúdo novo das montagens (importado, imposto de cima) que forjou uma experiência social nova: a formação e ampliação de um público teatral composto basicamente por operários e trabalhadores. Realizando deste modo a atitude à qual se referiu Canclini no seguinte comentário:

Para que as críticas dos artistas sejam algo mais que um murmúrio entre eles, precisam encontrar um espaço nos movimentos populares e representar aqueles que lutam para abolir as estruturas que oprimem não só os artistas, mas todos os trabalhadores ${ }^{287}$.

\footnotetext{
${ }^{287}$ A produção simbólica: teoria e metodologia em sociologia da arte, p.117.
} 


\section{Teatro experimental}

Salvo ledo engano, o termo "teatro experimental" surge no meio cultural colombiano em meados dos anos quarenta do século XX, para designar o gênero de produção teatral produzido por dois grupos teatrais recém-formados, o grupo da Universidade Nacional de Colômbia de Bernardo Romero Lozano, e o grupo de Fausto Cabrera, o Alta Comedia Elvira Travesti, ambos os nomes já mencionados no início deste capítulo (p.33). Em seguida, a partir dos anos 50, esta expressão “teatro experimental” se tornaria recorrente em abordagens críticas e históricas para se referir a uma vertente concorrente da vertente de teatro que evoluiria para o nuevo teatro, isto é, concorrente do teatro político ou engajado. Isso ocorre tanto nos comentadores coetâneos destes eventos quanto em estudiosos posteriores.

Nos anos 50, a referência a este termo se intensificou no meio teatral e cultural colombiano. Claudia Montilla está correta ao informar sobre a experimentação como característica da maioria dos grupos inclusive dos que se tornariam mais tarde TEC e LA CANDELÁRIA. Mas eram atribuídas principalmente às obras e às práticas de pesquisa do grupo EL BÚHO de Fausto Cabrera, empenhado nas montagens de peças integradas ao repertório da "última vanguardia mundial: Adamov, Ionesco, Ghelderode, Brecht, Tennessee Williams, Eugene O’Neill, García Lorca, Jean Tardieu, William Saroyan, etc." (González Cajiao, Historia, 290).

Parece haver certa confusão com o uso do termo "vanguarda", atribuída a expressões artísticas muito distintas e tardias. É certo que vanguarda e experimental são usados quase como sinônimos, tal como sugere a definição do termo por Patrice Pavis, segundo o qual:

O termo teatro experimental está em concorrência com teatro de vanguarda, teatro-laboratório, performance, teatro de pesquisa ou, simplesmente, teatro moderno; ele se opõe ao teatro tradicional, comercial e burguês que visa a rentabilidade financeira e se baseia em receitas artísticas comprovadas, ou mesmo ao teatro de repertório clássico, que só mostra peças ou autores já consagrados. Mais que um gênero, ou um movimento histórico, é uma atitude dos artistas perante a tradição, a instituição e a exploração comercial. ${ }^{288}$

\footnotetext{
${ }^{288}$ Patrice Pavis, Dicionário de Teatro, p. 388.
} 
No artigo "Del teatro experimental al Nuevo Teatro" de Claudia Montilla, essa abordagem é explícita. Ela se apropria das idéias de Eduardo Gómez, segundo o qual, haveria duas grandes tendências do teatro colombiano que se verificou desde os inícios da década de 50: “de um lado, a majoritária, dos que subordinam a criação artística às exigências partidaristas de uma concepção política; e de outro, a dos que exercem uma atividade artística experimental independente”. ${ }^{289}$.

Nesse artigo, Eduardo Gómez, arregimenta um conjunto de críticas ferozes ao teatro colombiano, tais como, sua inclinação ao populismo, sua militância política na arte, superficialidade e esquematismo na apropriação do que ele chama de "tendências esquemáticas de Brecht”.

Em última instância, o teatro colombiano não podia assimilar, nesta primeira etapa, ao teatro político de vanguarda em uma forma mais madura e criadora, porque, como temos visto, estava determinado por toda classe de fatores negativos, aos quais haveria que acrescentar a perseguição política num dado momento e a carência de meios materiais. Mas a inevitabilidade de um processo não autoriza a justificação passiva de suas falhas, nem menos sua entronização em novos mitos. ${ }^{290}$

Eduardo Gómez atribui à produção da maior parte dos grupos teatrais de Colombia uma oscilação entre ou "um modernismo medíocre” ou “concepção populista”. E conclui que o fator preponderante que tende a frear os avanços do teatro colombiano é uma concepção equivocada da eficácia política da arte, entendendo-a como agitacional e como ilustração pedagógica partidarista, até chegar, ultimamente, aos excessos de uma espécie de populismo de novo cunho. Denuncia o caráter idealizado e romantizado do "povo” descrito nos textos do teatro nacional revolucionário. “Não só o homogeniza como a parte "boa” e a "vítima”, mais ou menos inocente, do sistema, senão que também exagera-se com comodidade sua consciência política e sua capacidade de luta”. Com relação a Brecht, o crítico EG alude à forte influência do dramaturgo alemão sobre a grande maioria dos homens de teatro colombianos. Considera essa influência negativa, criticando tanto o Brecht "militante político", o "puritanismo empobrecedor do poeta quanto o Brecht pedagógico, ainda mais degradado ao ser apropriado por “países subdesenvolvidos”.

\footnotetext{
${ }^{289}$ Eduardo Gómez, “Materiales...”, op. cit., pp. 368-386.

${ }^{290}$ Eduardo Gómez, “Materiales...”, op. cit., p.384.
} 
O Teatro El Búho foi considerado o primeiro teatro experimental, independente e profissional, da Colômbia. Foi fundado por um conjunto de professores e artistas, entre os quais: Fausto Cabrera (espanhol), Santiago Garcia (colombiano), Marcos Tychbrojcher (colombiano de origem alemã), Sergio Bishler (frances), Dina Moscovicci (brasileria), e Aristides Meneguetti (uruguaio) ${ }^{291}$. Este grupo representou também a entrada do Teatro do Absurdo na Colômbia por meio das montagens feitas de obras de dramaturgos europeus e norte-americanos afinados com esta escola estética, como por exemplo, as montagens de obras de dramaturgos tais como Jean Tardieu, Yukio Mishima, Jean Anouilh; traduzem obras de Arthur Adamov, Michel Ghelderode, Fernando Arrabal, Eugène Ionesco, Gabriel Cousin etc.

\section{Nuevo Teatro}

Trata-se de um movimento de inovação teatral que se espalhou por quase todos os países da América Central e do Sul, entre as décadas de 60 e 80 do século XX.

O movimento do "Nuevo Teatro Latino-Americano" foi, de um modo geral, um movimento baseado na "redescoberta da memória cultural latino-americana”292. Cultura esta que fora objeto tanto de estrangulamento durante três séculos de colonização quanto de desvalorização nos séculos subseqüentes pelas “elites crioulas”, que se espelhavam então na cultura européia como forma de esquecer seu “complexo de inferioridade”. A emergência dessa cultura em meados do século XX se deve a vários fatores, entre os quais, focam-se sucinta e esquematicamente a difusão do pensamento marxista e anarquista por meio das diversas ondas de imigrantes europeus; a influência da experiência das vanguardas artísticas russa e européia; a intervenção de intelectuais ao enfatizar a importância dos estudos das culturas pré-colombianas bem como as contribuições das descobertas da arqueologia; uma certa desilusão com relação à cultura européia em face das duas guerras mundiais; um relativo crescimento econômico como conseqüência da Segunda Guerra Mundial - convém lembrar que o surto de industrialização estendível à quase

\footnotetext{
${ }^{291}$ Duque Mesa; Prada e Prada. Santiago Garcia: el teatro como coraje. Bogotá, Investigacion Teatral ed., 2004, p.23.

${ }^{292}$ Weiss, Judith A . Latin American Popular Theatre. Albuquerque, University of New Mexico Press, 1993.
} 
totalidade dos países da região, deu-se exatamente a partir do fim dessa guerra, quando os EUA se ocupavam com a reconstrução dos países europeus. E enfim, pela Revolução Cubana. Assim, o Nuevo Teatro "nasce” como resposta a um acúmulo de questões postas no transcurso do século XX. Nasce "a partir da necessidade de plasmar e reconhecer uma identidade cultural e de expressar 'o aqui e o agora,". ${ }^{293}$ Nasce a partir da necessidade de falar a seus contemporâneos das contradições intrínsecas à vida destes mesmos contemporâneos. Nasce do desejo de um povo de tornar-se sujeito de sua própria história. "É um novo espaço cultural que permite a expressão de temas e conteúdos que não haviam sido representados anteriormente. O nuevo teatro recria as vozes e as vivências dos diferentes grupos étnicos que conformam as populações colombianas”294 e latinoamericanas, além de mergulhar na história e nos mitos pré-colombianos na tentativa de recuperar do isolamento aqueles elementos comuns constitutivos da experiência e da memória coletivas como também do patrimônio cultural dos povos da região ${ }^{295}$. Ainda no encalço da compreensão do movimento, convém continuar a seguir a reflexão de Maria Mercedes de Velasco, segundo a qual, o Nuevo Teatro "se esforça em criar um espaço dialético, onde emissores e receptores recriam um mundo possível e aberto, distinto do mundo já definido e fechado da cultura dominante e da ideologia”296. Palco da combinação de distintas influências artísticas, o Nuevo Teatro é a "concretização de diferentes correntes dramáticas e estéticas que se adaptaram ao momento histórico-social e às necessidades de expressão de um povo”.

Por meio da reconstrução histórica do movimento, da análise de seus alcances estéticos e teóricos, e por fim, da reflexão sobre sua inquestionável contribuição ao processo de forja de uma “cultura nacional”, será possível confirmar a hipótese que levanta essa pesquisa, qual seja, a de que, a despeito de todo o seu engajamento sócio-político, o Nuevo Teatro buscou, pesquisou e realizou com autenticidade uma imagem teatral altamente poética, entendida no sentido deslindado na introdução do presente trabalho.

O vigor do movimento do El Nuevo Teatro surgido na segunda metade do século XX na Colômbia deve-se em grande parte à capacidade de absorver e reelaborar

\footnotetext{
${ }^{293}$ Mercedes de Velasco, María. El nuevo teatro colombiano, p.1.

${ }^{294}$ Mercedes de Velasco, María. El nuevo teatro..., op.cit. , p.2.

295 Ibidem, p. 2.

${ }^{296}$ Idem, ibidem.
} 
sincronicamente tanto os aportes mais inovadores da cena teatral européia quanto à capacidade de recuperação de sua própria herança, de sua "tradição” cultural, que remonta às práticas ritualísticas das populações ameríndias do período anterior à "Conquista", englobando as experiências do teatro colonial.

No transcorrer desse século (XX), a questão nacional e da identidade nacional se imporiam definitivamente. Todo o ideário que mobilizou as forças revolucionárias do teatro latino americano a partir dos anos 60 já estava em pleno andamento na Rússia prérevolucionária, nas três primeiras décadas do século XX. E as figuras ímpares deste movimento tinham sido Meyerhold no teatro e Eisenstein no cinema. De alguma forma, elementos dessa vanguarda russa influíram e tiveram ressonância no Nuevo Teatro. Os princípios que mobilizaram os artistas russos do início do século, bem explicitados por François Albera, em sua obra sobre Eisenstein, são próximos àqueles proclamados e reclamados por parte dos líderes e integrantes do movimento chamado de Nuevo Teatro latino americano como a idéia de “montagem”, “conflito” e “condensação”.

Albera mostra a aproximação dos artistas de vanguarda aos princípios do anarquismo, o que sem dúvida fizeram com que todos abraçassem o partido bolchevique pós-revolução, por vislumbrarem a possibilidade de concretização dentro do estado de direito político, seus ideais bem concretos com relação à aproximação entre arte e vida. Ele refuta a crença de que a politização do movimento de vanguarda tenha esvaziado o movimento, pelo contrário, foi a guinada à direita do partido comunista no que concerne a arte, que obrigou a dissolução do movimento na Rússia.

Na América Latina, durante o período do pós-segunda guerra, essas questões que começavam a mobilizavar os artistas, já estavam sendo objeto de reflexão por parte das disciplinas das ciências humanas, principalmente, a sociologia e a filosofia. A urgência de respostas consistentes mobilizava tanto artistas quanto intelectuais como as obras de Enrique Dussel e Leopoldo Zea mostram. Elas se debruçam sobre o continente a fim de compreender seu lugar, sua trajetória, sua história. Enrique Dussel conclama,

\footnotetext{
“... é necessário descobrir o lugar que cabe à América dentro do fuso que se utiliza esquematicamente na representação da evolução da humanidade".
} 
Ainda que a idéia de "evolução da humanidade" tenha como pressuposto a determinação histórica e, portanto, a idéia de progressão linear; a questão referente ao lugar que cabe à América Latina na geopolítica e econômica ainda permanece. E ainda que ele tenha como modelo de civilização, Europa e Estados Unidos, reivindica os benefícios da técnica sem por isso "perder nossa especificidade, nossa personalidade cultural latinoamericana, consciencializada na época e pela geração presente”. Para isso, ter-se-á de “...assumir a totalidade do nosso passado...”. (p.23). E Leopoldo Zea, por sua vez, perguntava-se em 1959: “qual é então nossa tradição? A resposta aqui é grave, porque nossa tradição, nosso passado, está formado por um contínuo indagar por nossa falta de tradição, de um contínuo perguntar por que não somos isto ou aquilo. Somos povos em suspense, expectadores de algo que não temos e que apenas podemos ter se deixarmos de lado essa expectativa, essa espera, esse duvidar de nossa humanidade, e agirmos, pura e simplesmente, em função do que queremos ser, e só isso"297.

Acredita-se que o movimento tenha surgido na Colômbia, a partir da conjunção de vários fatores determinantes, mas, principalmente, devido à abnegação explícita nas ações fortemente comprometidas com a "verdade" de dois homens de teatro: Enrique Buenaventura e Santiago Garcia. Estes dois homens fundam e lideram dois "grupos" teatrais: o "TEC” (Teatro Experimental de Cali) e o "La Candelária” de Bogotá. Ambos os grupos terão reconhecimento mundial por meio da premiação ao participarem em festivais de teatro internacionais.

De um dado ponto de vista, o início desse movimento quase se confunde com a fundação, em 1955, do TEC - Teatro Escuela de Cali (só em 1965, TEC passaria a significar Teatro Experimental de Cali), sob o recém assumido diretor Enrique Buenaventura. Mas nesse momento, os fundadores ainda não tinham consciência da dimensão que essa iniciativa iria atingir. De qualquer maneira, a partir dessa data, são postos em movimento gestos e discursos que norteariam os desdobramentos do movimento na medida em que estes fossem se tornando mais definidos e precisos, o que aconteceu no

\footnotetext{
${ }^{297}$ Zea, Leopoldo. La cultura y el hombre de nuestros dias. México: Unam, 1959, p.143).
} 
transcurso das décadas de 60 a 75. Mas costuma-se considerar como marco inicial do movimento, quando seus princípios e reivindicações começam a ficar mais bem delineados, o advento do Primeiro Festival Latino-Americano de Teatro Universitário, em 1968, na cidade de Manizales, Colômbia. Mas para se conseguir chegar a essa pequena vitória, foi necessário o acúmulo de pequenos eventos, aglutinando-se pessoas e energia em torno de um projeto comum: recuperação da "cultura popular” e "nacional”, cujos atos fundadores remontam aos princípios da década de 50, do século XX.

\section{As etapas do Nuevo Teatro colombiano}

Dada à complexidade do Nuevo Teatro, encontra-se pelo menos três estudiosos que tentaram classificá-los em fases, a fim de abarcar o movimento em sua totalidade. São eles Maria Mercedes de Velasco, Pablo Ázcarate e Vázquez- Zawadzki.

1. Maria Mercedes de Velasco propõe três etapas em que o movimento se pode classificar. Para ela "a historia do nuevo teatro colombiano se pode agrupar em três etapas: 1 . No primeiro período é um teatro escolar e universitário que era indiscutivelmente acadêmico. O público estava formado pelas minorias que tinham acesso à universidade e à cultura. 2. o segundo período corresponde à época da repressão oficial e do corte de verbas; é uma etapa popular que busca o público dos bairros pobres e das áreas rurais. Foi a época de expansão do movimento e de criação de um novo público. 3. o terceiro período corresponde à etapa da organização gremial; os trabalhadores do teatro se vinculam com outros sindicatos. $\mathrm{O}$ trabalho é planificado e sua esfera de ação é nacional. Este é o momento em que o teatro se compromete com o processo de desenvolvimento social. Como meio de expressão popular se organiza de acordo com a realidade e investiga a historia colombiana e os textos essenciais para a comunidade, representando-os com veracidade para que o público possa se enfrentar a eles e reconhecer suas contradições (p52-53).

2. Pablo Ázcarate propõe o ano de 1955 como a data inicial do Nuevo Teatro, devido ao fato de ela marcar o surgimento de novos grupos, pessoas e tendências que desembocarão no nuevo teatro. Assim, a primeira etapa seria de 1955 a 1961, considerada a da “decolagem”. A segunda etapa seria de 1961 a 1966; e a terceira, de 1966 a 1969. 
Como "tantas outras manifestações mais ou menos revolucionárias, o nuevo teatro no que tem de hostil ao sistema, foi engendrado por este como sua negação radical, graças ao histerismo defensivo dos aparatos ideológicos do próprio sistema”. Para a reconstrução histórica do movimento,

é indispensável situar o problema das lutas de classe e entender que muitos do problemas traçados pelo Nuevo Teatro se nutrem precisamente nas turbulências históricas e sociais,o que lhes garante atualidade e transcendência ${ }^{298}$.

${ }^{298}$ Mercedes de Velasco, Maria, El nuevo teatro colombiano, p.52. 


\section{POÉTICAS DO TEATRO POSSÍVEL}

Os grupos de teatro TEC - Teatro Experimental de Cali - e o La Candelária são considerados os dois carros-chefe do movimento teatral colombiano. Situados nas cidades de Cali e Bogotá, respectivamente, os dois grupos se tornaram pivô de uma história teatral peculiar desenvolvido nesse país. Tornaram-se conhecidos e bem conceituados internacionalmente ao participarem de festivais estrangeiros, ganhando prêmios e mais experiência.

\section{TEC: poética do sonho manifesto}

Ahora sabemos que un arte es realmente peligroso para el sistema cuando toma un camino. Enrique Buenaventura

Teatro Escuela de Cali; depois de 1967 TEC - Teatro Experimental de Cali

\section{Fundação do TEC}

O TEC como Teatro Experimental de Cali foi criado só em 1967, quando Enrique Buenaventura foi expulso da Escola de Belas Artes, onde dava aulas e mantinha uma “companhia” de teatro: o Teatro Escuela de Cali (também TEC), este surgido em 1962 num caráter de agrupação profissional e subvencionado por auxílios oficiais. Até esta data, Buenaventura montava seus espetáculos com alunos da Escuela Departamental de Teatro de Cali, que havia sido inaugurada em 1955 nas dependências da Faculdade de Belas Artes. Na época, Cayetano Luca de Tena, um diretor de teatro espanhol, fora contratado para a direção da escola, mas, passado alguns meses, percebendo o malogro de suas tentativas na preparação do espetáculo La Natividad, Luca de Tena renuncia, levando assim à assumpção da responsabilidade pela escola de teatro a diretora do Instituto de Belas Artes, porém apenas formalmente; na prática, quem a dirigia era aquele que se tornaria uma das figuras chaves da cena colombiana: o próprio Enrique Buenaventura”. 299

\section{Personalidade de Enrique Buenaventura (1925-2003):}

“...la vida no se puede ensayar y el teatro es un modo de ensayar la vida.”

\footnotetext{
${ }^{299}$ ESPINOSA DOMÍNGUEZ, Carlos. Por el camino del Tec In Escenarios de dos mundos, p.326.
} 
Nascido em Santiago de Cali, em 1925, o dramaturgo, ator, diretor, teórico do teatro, narrador, poeta, artista plástico e professor de teatro, Enrique Buenaventura teve uma vida consagrada ao teatro. Foi neto de um dos principais caudilhos liberais do Valle del Cauca, o general Avelino Rosas, cujas ações beligerantes valeram-lhe a alcunha de o “Leão do Cauca”. A infância de Buenavnetura, além de estar marcada pela recordação do avô general, esteve rodeada de histórias familiares que deram origem ao seu próprio imaginário, pleno de acontecimentos que posteriormente gerariam uma das dramaturgias mais ricas e prolíficas de Hispano-américa ${ }^{300}$.

De acordo com Tania Maza Chamorro, como bom "teatrista” que se preze, Enrique também fez teatro no colégio, dedicando à arte teatral a sua vida toda com a mesma devoção que quando criança celebrava missa na sala de casa para o deleite das tias beatas. Como jovem inquieto que era, estudou várias disciplinas: arquitetura, filosofia, letras, pintura e escultura.

Em 1945, começou sua peregrinação pelo Chocó e ao mundo da cultura de origem africana. Trabalhou no teatro com Carlos Chape e Andrés Crovo. Com a companhia do argentino Francisco Petrone, viajou para Venezuela e dali a outras regiões da América, tais como, Caribe, Brasil, Argentina e Chile, onde entrou em contato com os movimentos do Teatro Independente, com as manifestações da arte popular e com a história do continente. Em fins de 1955, regressou a Cali para trabalhar como assistente na recém criada escola de teatro, dirigida pelo já citado diretor espanhol Cayetano Luca de Tena ${ }^{301}$. Em seguida, acaba assumindo a direção da escola, como já aventado no início deste tópico, onde permanece até 1967. Nesse ano, é desvinculado do cargo de diretor e professor da escola devido à montagem de uma peça teatral que desagradou autoridades e governantes. A reação por parte de Buenaventura foi imediata com a fundação então de um teatro totalmente independente, o Teatro Experimental de Cali ('TEC), sendo considerada esta data o início propriamente dito do Nuevo Teatro colombiano. Buenaventura desenvolveria seu trabalho teatral ininterruptamente até sua morte em 2003. Desde os primórdios,

\footnotetext{
${ }^{300}$ Maza Chamorro, Tânia. “Enrique Buenaventura: o la suma elegíaca del teatro colombiano”. Home Page: http://casadeasterion.homestead.com/v5n19buena.html; capturado da Internet em 31/05/2006.

${ }^{301}$ JARAMILLO, Maria Mercedes; OSORIO, Betty. "El legado de Enrique Buenaventura”. In Revista de Estudios Sociales, no. 17, febrero de 2004, p.107-112.
} 
Enrique Buenaventura fora chamado o "pai do Nuevo Teatro colombiano"302 devido a seus incansáveis esforços como diretor, crítico e autor (p.107).

\section{Primórdios de sua Teoria Teatral}

Tanto para a Ciência quanto para a Arte, um dos fatores determinantes para seus avanços, descobertas e inovações, refere-se à capacidade de formular boas perguntas. E a pergunta que mobilizou Buenaventura desde o início e para cuja resposta construiu seu legado teórico-metodológico, além das obras teatrais propriamente ditas, foi exatamente: “que tipo de teatro debemos hacer”?

A questão assim cruamente formulada remete imediatamente à reflexão sobre quem é esse “nós” da pergunta? Quando Enrique Buenaventura a lança para si e seus contemporâneos, fica pressuposta outra pergunta, a saber, “quem somos nós”, isto é, que tipo de teatro devemos fazer para nós? E esquematicamente poder-se-ia deduzir que o "nós” ou "nosotros" da conjugação verbal refere-se em primeiro lugar a uma parcela da população da Colômbia, mas a Colômbia da década de 50 do século XX, a Colômbia da violência desmedida, da política bipartidarista, da guerra civil, da ditadura, da desapropriação dos camponeses. O "nós" antes de se referir a um determinado grupo de artistas ou de potenciais espectadores dessa sociedade, referir-se-ia aos homens que nasceram “colombianos”. Em segundo lugar, referir-se-ia a determinados grupos do conjunto de países da América Latina, que partilham uma história regional comum: a da cultura das populações indígenas do período anterior à Conquista, a da exploração da Colônia, a das lutas pela independência, e, enfim, a da exploração capitalista, da desigualdade social e da subjugação ao imperialismo capitalista e cultural. Responder à pergunta “que tipo de teatro devemos fazer” implica assim situar histórica e culturalmente tanto aquele que faz a pergunta quanto aqueles para quem a resposta resultará em algum tipo de benefício. E, finalmente, para Enrique Buenaventura, nas palavras de VáquezZawadzki, significava respondê-la a partir “dos espaços teatrais determinados pela história política, econômica e cultural da Colômbia, e concretamente da historiografia regional da

\footnotetext{
${ }^{302}$ MERCEDES de VELASCO, María. El nuevo teatro colombiano. (p.107)Refe.
} 
cidade de Santiago de Cali e do Departamento do Valle del Cauca ${ }^{303}$. Esta interrogação fundamental perpassaria a totalidade do trabalho artístico do autor colombiano, levando-o a se embrenhar na história "não-oficial” do país e do continente, nas culturas populares e seus mitos, no estudo teórico e metódico da arte teatral, numa verdadeira práxis dialética. ${ }^{304}$ Mas de onde teria surgido em Buenaventura a formulação dessa questão? O que leu ou viu? Que influência poder-se-ia detectar no processo que desembocou nessa consciência crítica, que na busca de respostas consistentes forjou todo o seu pensamento e o seu legado artístico e teatral?

No artigo "El teatro de Enrique Buenaventura y la afirmación popular”, VázquezZawadzki se debruça exatamente sobre esta questão. Busca detectar, tanto nos primeiros textos lidos pelo encenador calenho quanto nos primeiros textos escritos por ele, o momento em que teria ocorrido a "sua primeira reflexão sistemática” sobre a arte, ainda na etapa inicial de sua produção teatral, que contivessem indícios de suas formulações estéticas como apareceriam mais tarde. A chave para entender essa fase inicial do surgimento do TEC repousa no que é considerado o primeiro artigo de Buenaventura: “De Stanislavski a Brecht”. Esse texto foi publicado na revista Mito, principal veículo da inovação das idéias e teorizações artísticas vindas da Europa e dos Estados Unidos. Parece ter sido também por meio dela, conta Vázquez-Zawadzki, o primeiro contato de Buenaventura com as idéias de Bertolt Brecht, aquele que exerceria grande influência no espírito do diretor colombiano assim como no dos principais nomes do teatro latinoamericano do continente. O número 21 dessa revista, por exemplo, “correspondente aos meses de setembro-outubro de 1953, [foi] consagrado - quase totalmente - ao teatrólogo alemão, que desde essa data [estaria] entronizado (...), teórica e praticamente, no fazer e saber cultural do país”. Dele, publicam-se três textos importantes: Cinco dificuldades para quem escreve a verdade, A exceção e a regra (peça didática) e Os sete pecados capitais. Ainda segundo a leitura de Vázquez-Zawadzki, a publicação do número 21 da revista Mito significou, de um modo geral, uma tomada de posição da intelligenztia colombiana frente ao conjunto da vida sócio-cultural do país. Nela, é publicado também, como texto de

\footnotetext{
${ }^{303}$ VÁZQUES-ZAWADZKI, Carlos. El teatro de Enrique Buenaventura y la afirmación popular. Site: www.revista.agulha.nom.br/ag33buenaventura.htm, acesso em 01/10/2006.

${ }^{304}$ VÁZQUES-ZAWADZKI, Carlos. El teatro de Enrique Buenaventura y la afirmación popular. Site: www.revista.agulha.nom.br/ag33buenaventura.htm, acesso em 01/10/2006.
} 
abertura, um artigo curto de Georg Lukásc, denominado: "Bertolt Brecht soube provocar crises saudáveis”, cuja tese era a de que o procedimento literário baseado em questões abstratas, convertidas num fim em si mesmo, presentes em obras de autores consagrados como Ibsen e Tchekov, resultava no escondimento do objeto real, do objeto em si, o que por sua vez se mostrava como uma operação perigosa que contradizia a missão da arte e da literatura. Nesse contexto, Brecht surgia como o único que teria encontrado um equilíbrio em virtude do rigor de suas perguntas “desconcertantes” a problemas atuais, construído de modo a deixar perceber a certeza da resposta final. Convêm reproduzir trechos deste texto, recortado por Vázquez-Zawadzki, que mostram com clareza a crítica de Lukasc: “Todas as perguntas que ele [Brecht] faz e as respostas que as justificam, teriam nascido dessa necessidade da humanidade de libertar-se da indignidade na qual há tido que edificar, na vida social, uma pátria à medida do homem”. E ainda:

Seu desejo mais profundo é o de transformar as massas, os espectadores, o auditório de suas peças. Quando estes abandonam o teatro devem estar não só comovidos senão transformados: orientados praticamente ao bem, à lucidez consciente, à ação, ao progresso. O efeito estético tem a função de produzir uma conversão moral, social.

Deste modo, Enrique Buenventura também teria buscado este tal equilíbrio, sem, no entanto, conseguir encontrá-la inicialmente, na leitura de Vázquez. Mas, de qualquer maneira, as coordenadas que serviriam de âncora ao Nuevo Teatro já tinham sido lançadas desde então neste supostamente primeiro texto de Buenaventura, publicado na revista Mito em 1958. A partir daí, ele tentará responder, apoiado em Brecht, “às interrogações sobre realidades contemporâneas latino-americanas...”, produzindo “impasses”, pontos mortos, grau zero no fazer teatral ${ }^{305}$.

Vázquez- Zawadzki divide o trabalho teórico de Buenaventura em duas grandes etapas:

$1^{\circ}$. teatro oficial - de 1955 a 1967: trabalho realizado no interior da Escuela Departamental de Teatro (1955 a 1962), juntamente com a etapa do Teatro Escuela de Cali (de 1962 a 1967), num período total que vai de 1955 a 1967.

\footnotetext{
${ }^{305}$ VÁZQUES-ZAWADZKI, Carlos. El teatro de Enrique..., op. cit.
} 
$2^{\circ}$. teatro independente - de 1967 até a sua morte em 2003. Trabalho realizado pelo Teatro Experimental de Cali, T.E.C., formado agora sem subsídios oficiais.

Este primeiro texto de Enrique Buenaventura, De Stanislavski a Brecht, constituiria assim o primeiro esforço teórico do autor numa etapa de seu processo de trabalho que representaria o momento fundador do Nuevo Teatro colombiano.

Além de nortear a prática teatral de Buenaventura, muitas idéias presentes neste texto seriam retomadas em escritos posteriores tais como A arte não é um luxo e Teatro $e$ Cultura. Não importa que seja negando ou confirmando certos princípios contidos nele, importa sim saber que ele representa o texto seminal, o germe do desenvolvimento e amadurecimento de um movimento sem paralelo na América Latina: o Nuevo Teatro.

Uma das principais idéias contidas no texto A arte não é um luxo refere-se à conclusão do autor sobre a necessidade da arte, depois de ter experimentado muitas crises referentes ao incômodo da sensação de que a arte "para nós, aparece muitas vezes como um luxo a que não temos direito”306. Buenaventura relata assim a cena que acabou por convencê-lo da necessidade da arte:

“Já que (...), negros, carregadores, pescadores, operários de curtume e de serralheria, dokers e marinheiros de pequenos barcos de cabotagem experimentavam a necessidade de dançar durante três dias seguidos, de fazer teatro e pantomima, a arte devia ser necessária, não devia ser uma atividade reservada aos ‘intelectuais’.”307

Neste texto surge também a formulação de novas questões como a relacionada à cultura popular: "quais eram as formas de teatro popular que sobreviviam em nossos campos e que estavam talvez em vias de desaparecer?” Como o próprio Enrique Buenaventura explana, cada nova montagem teatral era tentativa de resposta naquele momento da pergunta eterna: “que tipo de teatro devemos fazer", levando-o a "revisitar" constantemente seus próprios conceitos sobre o que era a cultura ou a arte popular. Essa atitude de questionamento, de crítica e auto-crítica, pode ser apreciada principalmente no texto Teatro e Cultura, posterior aos dois anteriores e por isto mesmo detentor de certo amadurecimento com relação à reflexão de tais problemáticas. A formulação da crítica do

\footnotetext{
${ }^{306}$ BUENAVENTURA, Enrique. “A arte não é um luxo”. Cópia do artigo pode ser encontrada em anexo na dissertação de mestrado de Marília Carbonari, Teatro épico na América Latina, defendida em 2006 no Prolam/USP. 307
} 
conceito de "cultura”, de "folclore" e de "arte popular" permite o vislumbre de um projeto urgente de “descolonização cultural”. Nesse texto, Buenaventura começa confessando que nunca teve "simpatias" por essa "palavra vaga, que serve para tudo", que é a idéia de cultura. “Que é a cultura para um homem de teatro que trabalha na América Latina?”. De uma obscura falta de simpatia pelo termo, o autor conta que pouco a pouco foi se dando conta do que era a cultura e “minha desconfiança foi se tornando rechaço consciente”, pois:

A cultura é algo preparado e elaborado na Europa e nos Estados Unidos que nós devemos tratar de vender aqui. Com relação ao teatro, o produto nos chega com todas as instruções de como desempacotá-lo e estendê-lo aos clientes. Há que fazer viagens, é claro, à metrópole para assistir às montagens, técnicas de atuação, sistemas inovadores de comunicação, para estar em dia. ${ }^{308}$

E aqui não dá para deixar de pensar na similaridade ou complementaridade de uma idéia formulada por Walter Benjamim, segundo a qual, "nunca houve um monumento da cultura que não fosse também um monumento da barbárie. E, assim como a cultura não é isenta de barbárie, não o é, tampouco, o processo de transmissão da cultura.”309 Assim, “todos os bens culturais”, ainda segundo Benjamim, “que [o materialista histórico] vê, têm uma origem sobre a qual não pode refletir sem horror.”310 Daí a recomendação de Walter Benjamim para que o materialista histórico se desvie dessa cultura bárbara. De certo modo, a percepção de Buenaventura e de Santiago Garcia (como será visto no sutópico seguinte) vai ao encontro dessa idéia em suas obras de cunho histórico, nas quais eles realizam aquilo que Walter Benjamim detecta na postura do materialista histórico, o de considerar sua tarefa como a de "escovar a história a contrapelo" 311. Nesse sentido, as questões colocadas pelos encenadores do Nuevo Teatro estão muito próximas da cultura de resistência de Marta Traba, da denúncia da miserabiliade da estética da fome de Glauber Rocha e de muitos outros movimentos revolucionários.

\footnotetext{
${ }^{308}$ BUENAVENTURA, Enrique. “Teatro e cultura”. In WATSON ESPENER, Maida; CARLOS REYES, José. Materiales para una historia del teatro en Colômbia. Bogotá, Instituto Colombiano de Cultura, 1986, p.286. Este texto pode ser encontrado também em outras publicações como a da Revista de la Escuela de Teatro, No. 3, Medellín, 1970, ps.20-34.

309،Sobre o conceito de história” In: Magia e técnica, arte e política. São Paulo, Brasiliense, 1994, p. 225. (Obras Escolhidas v.1).

310 “"Sobre o conceito de história”, op. cit. p.225.

311 “Sobre...” idem, ibidem, p.225.
} 
Outra questão de fundo percebido pelo autor refere-se ao público: “o problema mais grave que temos é a clientela. A necessidade de consumir esses produtos (as peças teatrais estrangeiras) - criados para uma clientela culta e habituada - não a tem nossos possíveis clientes. Há que criá-la”312. Se na Europa o advento do teatro moderno foi resultado da emergência de novos conteúdos para um público já formado e cada vez mais crescente, o advento do Nuevo Teatro na Colômbia e na América andina inverte radicalmente o sentido dessa lógica e, num curto espaço de cerca de 15 anos, o que se vê é exatamente o oposto: $\underline{\text { }}$ conteúdo novo das montagens teatrais é que forja uma experiência social nova, propiciando a formação e ampliação de um público de teatro composto basicamente por operários e trabalhadores.

Enfim, como lembra Giogio Antei, essa geração de artistas estava mais preocupada com essa capacidade de formular perguntas do que propriamente dar-lhes respostas (p.175). E foi justamente essa disposição permanente na formulação de questões que deu origem a todo o pensamento teatral e método de trabalho de Enrique Buenaventura.

\section{Método de Trabalho Coletivo do T. E. C.}

Além do texto Teatro y Cultura, para entender o processo de trabalho coletivo do T.E.C. é de suma importância o estudo de dois outros textos do próprio coletivo, publicados ambos depois de 1968. E isso quer dizer depois que Enrique Buenaventura e seu grupo perderam “o apoio do governo”, em função da montagem La Trampa, de 1966 - drama baseado na corrupção política do regime do ditador guatemalteco Ubico -, ${ }^{313}$ quando então o TEC foi obrigado a dar início a uma nova fase de sua história, tornando-se pela força das circunstâncias um grupo de teatro independente.

Estes dois textos são: 1. La interpretacion de los sueños y la improvisacion teatral, cuja nota de rodapé informa que se trata de uma "charla" com os atores do TEC, de 1969; e, 2. Esquema General del metodo de trabajo colectivo del T. E.C., publicado primeiramente

\footnotetext{
${ }^{312}$ Idem. Ibidem. Op. cit. p.286.

${ }^{313}$ WATSON ESPENER, Maida. "La teoria teatral de Enrique Buenaventura”. In WATSON ESPENER, Maida; CARLOS REYES, José. Materiales para una historia del teatro en Colômbia, p.348.
} 
nos Cuadernos de Teatro, No. 8., pela Corporación Colombiana de Teatro e atualizado pela Comisión de Publicaciones del T. E.C., em junho, julho e agosto de 1975.

Há indícios fortes, neste e em outros textos do encenador, concernentes a preocupações de ordem estética e formal, que não são muito explorados por estudiosos. Que se comece aqui então pelo primerio texto, sobre a interpretação dos sonhos e a improvisação teatral.

O primeiro texto, La interpretacion de los sueños y la improvisacion teatral, como o próprio título traz explicitamente, trata-se da apropriação das leis da interpretação dos sonhos, como Freud as descobriu e experimentou, para em seguida, por meio da associação, aplicá-las à mprovisação teatral.

Buenaventura utiliza a imagem do sonho para falar da relação entre texto e subtexto. Tanto o sonho como o texto são conteúdos manifestos de um conteúdo latente muito mais amplo e complexo. O conteúdo latente do texto seria assim o subtexto. As leis que regem a elaboração do sonho, descobertas por Freud, seriam as mesmas que regem a elaboração da arte, dos mitos, das lendas e rituais. Ao aplicar estes princípios na improvisação, poderiam ser desvendadas assim todas as conexões e fios que conduzem a ação do conteúdo latente ao manifesto. Buenaventura cita uma passagem importante de Freud para esclarecer como se dá esse processo. Assim escreve ele:

Na análise [do sonho] como a descreve Freud, há dois aspectos:

1. A livre expressão de todos os elementos do sonho, permitindo todo tipo de associações involuntárias que, fora deste caso, são sempre rechaçadas pela crítica como escorias sem valor algum, que perturbam nossa reflexão.

2. Este material que está acumulado sem ordem, ao ser analisado com um método, permite-nos recorrer o caminho contrário ao que recorreu a elaboração do sonho, isto é, ir do conteúdo manifesto ao conteúdo latente. $^{314}$

Ao aplicar este procedimento à improvisação, segundo Buenaventura:

1. Devemos estabelecer claramente as situações delineadas pelo texto, tendo cuidado de ver que no texto, como no sonho, não há apenas situações, mas outros elementos próprios do texto: metáforas, comparações, etc.; com situações exclusivamente seria prescindir de

\footnotetext{
${ }^{314}$ BUENAVENTURA, Enrique. "La interpretacion de los sueños y la improvisacion teatral”. In WATSON ESPENER, Maida; CARLOS REYES, José. Materiales para una historia del teatro en Colômbia, p. 298.
} 
grande parte de sua riqueza, convertido em um instrumento puramente descritivo. Isto, que é válido para o cinema, não o é para o teatro.

2. Estabelecidas claramente as situações, abrimos as mais amplas possibilidades para as associções livres, involuntárias dos atores. É indispensável que, neste processo, não haja crítica, não se delineie "o que voce qeur dizer com isso" ou "isso não corresponde à idéia que queremos mostrar”, porque isso converte a improvisação em pantomima ilustrativa. Os atores... devem ater-se às situações e se manter dentro delas, ... até esgotarem todas as possibilidades.

3. O trabalho reflexivo do diretor e dos atores não deve consistir em escolher as melhores imagens, gestos ou cenas, senão em distinguir o fio condutor que une todas as associações livres. (...) Tratar de formar um todo que espresse o maior número de possibilidades, o maior número de pontos de vista ou facetas da situação.

4. O trabalho seguinte consiste em voltar ao texto para uma confrontação entre o conteúdo latente e o conteúdo manifesto. Esta confrontação deve ser feita com as imagens conseguidas mediante a improvisação das ações.

5. Feita esta análise, podemos buscar uma correspondência entre o texto e as imagens que representam as situações, de modo que o texto não seja embutido como um "recheio" nas formações rígidas das situações, ou como uma justificação mais ou menos acomodada destas imagens. ${ }^{315}$

Depois desta fase do processo, Buenaventura continua apontando os pontos de contato entre as elaborações dos sonhos e das criações artísticas, como o mecanismo da contradição ou dramatização, presente nos dois processos: "as imagens conseguidas mediante a livre associação na improvisação e que representam uma situação podem contradizer as idéias do texto, colocando-as em questão sem negá-las”, 316

O mecanismo da contradição ocorre no sonho do seguinte modo: “o conteúdo manifesto [do sonho] pode ser a antítese absoluta do latente sem se negar um ao outro.”317

Trata-se, enfim, de um mecanismo presente na própria vida do homem e que é a base fundamental da arte, isto é, de compreender a contradição “entre nossas aspirações legítimas de realização plena e a conduta cotidiana que as nega e as reprime.” Assim é que fica mais claro também o conselho que Henry Miller deu a Jorge de Andrade, quando porguntado por este numa visita aos Estados Unidos sobre como escrever uma obra prima.

\footnotetext{
${ }^{315}$ BUENAVENTURA, Enrique. “La interpretacion de los sueños y la improvisacion teatral”. In WATSON ESPENER, Maida; CARLOS REYES, José. Materiales para una historia del teatro en Colômbia, p.299-300. 
Miller respondeu: volte a seu país e escreva sobre a diferença entre o que os homens gostariam de ser e o que são realmente.

Outro mecanismo comum aos dois processos, segundo a teoria de Buenaventura, trata-se do processo de condensação, que aparece na Interpretação dos sonhos de Freud, referindo-se aí ao processo de compressão das infinitas idéias latentes num número limitado delas presente no conteúdo manifesto do sonho. Esta seleção seria operada no processo de elaboração desse conteúdo latente, por meio das representações, que a consciência necessita para ter acesso a esse "submundo" da inconsciência. Buenaventura cita Freud na seguinte passagem:

se... comparamos o número dos elementos de representação do conteúdo manifesto com o das idéias latentes, cujo vestígio aparece no sonho e que nos foi descoberto por meio da análise, não podemos duvidar de que a elaboração do sonho levou acabo uma grande compressão ou condensação. ${ }^{318}$

Haveria vários tipos de condensação como, por exemplo, o uso da metáfora, ou idéias sobrepostas, ou um produto misto de idéias contrárias. Outra "lei fundamental do sonho" é o deslocamento. Trata-se do mecanismo por meio do qual "algumas idéias fudamentais do conteúdo latente aparecem representadas de modo insignificante no conteúdo manifesto.”319 Para a ilustração de um tipo de deslocamento, Buenaventura dá o seguinte exemplo "de um personagem que diz grandes idéias, realize uma ação insignificante”, que foi utilizado numa improvisação.

Enfim, o deslocamento é um tipo de "translação de intensidade psíquica ou carga emotiva de uns elementos para outros e de uma situação para outra”. Nesse sentido, Buenaventura considera o texto de uma peça como uma tentativa de interpretação do conteúdo latente que o autor realiza durante a elaboração da própria peça. Além da contradição, da condensação e do deslocamento, Buenaventura se refere a um quarto aspecto desenvolvido por Freud, que é o estado de repressão, que dá origem ao conceito de deformação do sonho.

Não posso então fazer outra coisa que admitir uma relação causal entre a obscuridade do conteúdo do sonho e o estado de repressão, ou seja, a incapacidade do suceder consciente de algumas idéias, e me vejo

\footnotetext{
${ }^{318}$ Freud, citado por Buenaventura, op.cit., p.301.

${ }^{319}$ Freud, citado por Buenaventura, op.cit., p.303-304.
} 
obrigado a concluir que o sonho tem que ser obscuro para não revelar as idéias proibidas latentes.

Buenaventura associa este mesmo processo de repressão à arte. Qual seria o papel da repressão na arte? A arte, segundo o autor, usaria os mesmos mecanismos que o sonho, mas a elaboração do material latente seria contrária à do sonho, de modo que os conteúdos manifestos, na arte, apareceriam dentro do contexto que os reprime, e surgiriam criticando este contexto". Essa constatação leva à conclusão do papel subversivo da arte, no sentido de ela se apresentar não como comprovação, mas como "rebelião e denúncia, como vontade consciente de mudança.” E a aplicação destes princípios na improvisação teria por objetivo trazer à tona os conteúdos latentes; nela, os atores podem encontrar as conexões profundas entre estas conteúdos latentes e a peça.

A improvisação é preparada por analogia. Depois de reler o texto da ação ou unidade menor de conflito, depois de colocar um título que relacione a situação particular da ação com suas implicações em toda a peça, os atores criam uma pequena fábula análoga que serve de estímulo. ...o estímulo é o objeto de concentração do ator... Devem ser concretos e objetivos, de modo que desperte o impulso do ator e suas associações livres. ${ }^{320}$

Os estímulos são concretizações de um complexo de idéias do texto deslocado para um elemento e condensado nele. A improvisação serve para encontrar a verosimilhança do conflito, isto é, a verosimilhança do real e não do aparente, a verosimilhança da exceção, que não só não confirma a regra, como também a coloca em questão.

Não obstante o uso de mecanismos similares, há muitas diferenças entre o sonho e a improvisação. Enquanto a tarefa primordial do sonho é conservar o sonho, não despertar a consciência do sujeito que dorme, o trabalho artístico é exatamente o contrário: busca "todo o repremido, não para expressá-lo livremente, mas para mostrar as causa concretas da repressão”. Na arte, a indagação supera o conflito indivíduo-sociedade ao ter "em si mesma um caráter crítico desenvolvido”. Na improvisação, “a realização mesma do conflito revela a repressão e a crítica. Por isso a crítica não é a atitude senão a ação.”321

\footnotetext{
${ }^{320}$ BUENAVENTURA, E. “La interpretacion...”,op. cit., p.309. Grifo do autor do texto.

${ }^{321}$ BUENAVENTURA, E. “La interpretacion...”,op. cit., p.310-313. Grifo do autor do texto
} 
Para finalizar as referências a este texto de Buenaventura, convém evocar ainda a seguinte passagem: "o ator e o espectador não se limitam a participar de uma experiência: realizam a experiência e ao mesmo tempo refletem sobre ela, a criticam.” E finalmente, “ao improvisar o ator um conflito, desata seus próprios conflitos, relaciona a energia contida no conflito com sua própria carga psíquica, faz um deslocamento por analogia, como o poeta ao criar suas imagens.”

Este texto de Buenaventura revela sua autonomia com relação a todas as tradições ou sistemas de criação teatral que tenham aportado na América Latina. Apropria-se de todas elas sempre através de um viés crítico. Apropria-se conscientemente, sem se tornar subserviente de nenhuma delas. Ao se deter na interpretação dos sonhos de Freud, descobre seu caminho particular para ter acesso aos processos de criação artística. E ao mesmo tempo, aproxima-se do Surrealismo dos anos 20-30 europeu pelo menos em relação à apropriação das reflexões freudianas como detonador do exercício de criação da arte. Tratase de um texto que está distante da ênfase absoluta à influência brechtiana, sem que essa constatação negue sua influência, mesmo que o próprio Buenaventura faça referência o tempo todo ao teórico alemão e não esconda sua admiração por ele. Pretende-se apenas chamar atenção para um aspecto bastante particular da prática artística do encenador colombiano: sua capacidade de transformar, de proceder ao deslocamento e condensação de todas estas influências estrangeiras referentes à criação artística, de acordo com o que ele perseguia em sua arte: algo parecido com o que Walter Benjamim se referiu em algum lugar de poética política.

O segundo texto refere-se, como já aventado, a um esforço de sistematização da matéria artística desenvolvida na prática. Este texto, de 1975, propõe-se a teorizar e a descrever o método de trabalho que eles vinham desenvolvendo. É sobre este texto que se tratatá daqui em diante.

Diferentemente de Santiago Garcia, para quem a cada novo trabalho um processo novo também surgia, Buenaventura tem necessidade de sistematização e de criação de um método para o seu processo de criação artística juntamente com seu grupo. Essa necessidade dá origem à escritura de Esquema General del metodo de trabajo colectivo del T.E.C. Não há dúvida de que um dos aspectos fundamentais do movimento do Nuevo Teatro esteja relacionado a esta necessidade por parte de seus ícones mais engajados, qual 
seja, a de fazer acompanhar toda prática por uma reflexão constante, capaz de revigorar continuamente sua busca estética e política. A reflexão teórica produzida pelos artistas do movimento representa em primeiro lugar uma tomada de consciência da importância da ciência para arte, e nisso se alinhando a Meyerhold, Bertolt Brecht, Piscator e outros; e, em segundo, ao legar material de registro de seus processos, permitiu-se de um lado uma espécie de “oficialização" por meio desses documentos de uma determinada realidade histórico-cultural; e de outro, foi permitiu também a possibilidade de se tornarem objeto de estudo e de novas reflexões posteriores.

Neste texto, Buenaventura traça com maior nitidez o seu método de trabalho. Como Eisenstein, enfatiza o método como condição necessária da criação, o que o colombiano, deve-se necessariamente incluir o fator do trabalho coletivo: "só se o método [for] conhecido e manejado por todos os integrantes do grupo e aplicado de modo coletivo, garant[ir-se-á] uma verdadeira criação coletiva” ${ }^{\text {,22 }}$. Este texto foi subdividido em diversos tópicos, cujos pontos principais seguem resumidos abaixo ${ }^{323}$ :

I. “Trabalho e método”. Mostra como a improvisação foi se impondo como ponto de partida para a montagem de uma peça teatral.

II. “¿Teatro com texto ou teatro sem texto?”. Questiona o que normalmente se entende por "texto teatral”, definindo-o como aquilo que pode ser um esquema de conflito que se representa inclusive sem palavras. A análise de um texto do ponto de vista do teatro buscaria não um discurso científico ou uma análise exaustiva, mas um discurso artístico ou o discurso de montagem, cujo cerne estaria na identificação do conflito central.

III. “A trama e o argumento”. Inspirado em definições de Tomachevski (integrante dos formalistas russos), Buenaventura aponta aqui sua ligação com a vanguarda russa por meio destes formalistas; par quem trama seria o conjunto de acontecimentos vinculados entre eles [...],

\footnotetext{
${ }^{322}$ In Materiales..., p.314.

${ }^{323}$ Trata-se ainda do texto Esquema General del metodo de trabajo colectivo del T. E.C. , que, a propósito, será a fonte de todas as citações diretas e indiretas subseqüentes até outra nota indicativa. Vale lembrar também que a publicação a que se teve acesso neste trabalho foi aquela impressa na obra Materiales para una historia del teatro en Colombia, de Watson Espener e José Reyes já referida neste trabalho, pp.314-346.
} 
seguindo a ordem natural, ou seja, a ordem cronológica ou causal dos acontecimentos. A esse respeito, Buenaventura esclarece:

esta ordem causal não é rígida. É necessário ter em conta que um acontecimento associado engendra outro acontecimento associado, mas poderia engendrar um terceiro, um quarto, etc. Ainda que pareça um fato sem importância, esta possibilidade é muito significativa e digna de se ter em conta, pois, as "alternativas mortas", as que não acontecem na obra mas que poderiam acontecer, impedem que a ordem causal seja vista como ordem fatal. Brecht insiste nisso, que se deve levar isso em consideração não somente na montagem mas também na atuação, e o aponta como um dos elementos principais do "distanciamento". Os acontecimentos associados são, pois, como "pivôs" ou "encruzilhadas". A partir de qualquer um deles, o relato poderia tomar outro rumo, mas também o rumo que leva ao acontecimento associado seguinte, e o fato de que foi tomado esse caminho e não outro deve ficar claro na montagem ${ }^{324}$.

Depois disso, constro-se a fábula cronológica, cada um dos atores conta um “conto”, sobre o relato. A mesma referência a Tomachevski vale também para a categoria de argumento, segundo o qual, é composto pelos mesmos acontecimentos da trama, mas agrega ainda outros, aparentemente menos decisivos, denominados "livres” ou “auxiliares”. Estes acontecimentos dependem mais dos personagens. Segue uma ordem temporal estabelecida pelo relato e não pelo cronológico.

IV. “Tema central”. É estabelecido ao identificar o conflito central, por meio da identificação das 1. “forças gerais em pugna”; e 2. “da motivação geral”, ou seja, a razão pela qual entram em conflito no nível argumental estas duas forças. Dito de outro modo, motivação é aquilo pelo qual se enfrentam duas forças.

V. “Divisão do texto”. 1. Seqüência. 2. Situação. 3. Ação. “As ações são as unidades básicas de conflito” e “...estão determinadas pela motivação”.

VI. “A improvisação”. O conflito “sobre o qual se improvisa deve ser concreto”. Deve ser livre, mas com objetivo concreto; deve ser “um jogo desde que se tenha fixado seus limites e regras”. A libertade e o jogo são procedimentos que permitem não converter a montagem em ilustração

\footnotetext{
${ }^{324}$ In Esquema general..., p.319.
} 
de conceitos e idéias pré-formados sobre o texto, “é o que nos permite questionar nossa própria visão ideológica do texto”325.

É neste tópico sobre a improvisão que Buenaventura recorre à idéia de imagem para falar da criação cênica. Ele diz, por exemplo, que "o discurso de montagem é um discurso inconográfico, formado fundamentalmente por imagens”. E ao desenvolver essa idéia, torna-a ainda mais explícita, como se pode conferir na seguinte passagem:

A ideologia do grupo, seu compromisso estético-político com um público determinado, a ação do grupo sobre a sociedade, etc., todo o que constitui a racioanlidade do grupo, seu pensamento, orienta numa direção o discurso de montagem, organiza a escritura e, portanto, a leitura das imagens, no que se refere à seleção e à continuidade, mas as imagens têm uma autonomia que não é redutível nem traduzível a conceitos. São necessariamente polissêmicas e, portanto, rechaçam toda significação unívoca ${ }^{326}$.

Curioso que, em ao menos uma ocasião, Buenaventura necessita, ao se referir à imagem, explicar entre parênteses que se trata de imagens visuais e sonoras. Além disso, destaca que “a ideologia não pode se ver como ‘o conteúdo’, como ‘a mensagem', como o determinante do discurso da montagem e as imagens como o ilustrativo, como o secundário, como a 'forma',327. Para ele, “semelhante concepção puramente ideológica da prática artística [...] impede a teorização do trabalho [...] e se converte em obstáculo [...] para a evolução do trabalho mesmo...”328. E, finalmente, ele afirma que "as improvisações são as criadoras das imagens que conformam o discurso de montagem”.

Embora Buenaventura não evoque o sintagma “imagem poética” explicitamente, toda sua reflexão está voltada para afirmar a sua importância no contexto da criação teatral. Três conceitos aparecem de forma recorrente na estrutura de seu método: improvisação, imagens e discurso de montagem. O imbricamento sugerido por essas idéias revela não só um certo amadurecimento na busca estética do artista como também, e principalmente, a profundidade de seu engajamento na pesquisa artística e estética de seu teatro

\footnotetext{
${ }^{325}$ Final da referência central sobre o texto de Buenaventura, Esquema general...”.

${ }^{326}$ Buenaventura, E. “Esquema general...” In Materiales..., pp.333-334.

${ }^{327}$ Buenaventura, E. "Esquema general...”" In Materiales..., p. 334.

${ }^{328}$ Buenaventura, E. “Esquema general...” In Materiales..., p. 334.
} 
comprometido. Para além de todo o teatro político empenhado na transformação social da realidade, fica evidente uma preocupação com o rigor da forma bem como um adensamento na busca pela imagem poética.

Indícios dessa preocupação aparecem em outros textos de Enrique Buenaventura, nos quais aproveita também para demarcar sua distância com relação a Brecht. Num deles, pode-se ler afirmações como a de que "nosso trabalho se situa mais no Mitos que no Logos”. Em suas próprias palavras, ele continua assim:

Tratamos a obra, o texto escrito, como um Tema. O texto, como escritura, foi escolhido, foi estabelecido seu eixo de seleção-substituição. Foi dito isto e não aquilo. Foi deixado de lado aquilo que Brecht chama de "alternativas mortas". Brecht busca modos de recuperar estas alternativas especialmente na atuação. Nós, no trabalho de equipe e ligado a ele, buscamos estas alternativas mortas coletivamente, por meio das improvisações por analogia que realizam as equipes de atores. Brecht trabalha com um logos que abre a porta ao mito, nós trabalhamos com um mito que abre a porta ao logos ${ }^{329}$.

Para corroborar o que se vem tentando mostrar até aqui, isto é, a presença de um aspecto pouco valorizado na obra teórica de Buenaventura, aquele concernente à preocupação com a pesquisa estética e o rigor formal, talvez baste indicar o fato de que Buenaventura foi leitor de Bachelard, o filósofo da poesia. No texto abordado acima, encontra-se a certa altura a seguinte passagem: “é bom ter em conta o aforismo de Bachelard: 'os pensamentos não se imaginam, as imagens não se pensam”330.

Buenaventura foi um estudioso antenado com o pensamento europeu mais avançado e ao mesmo tempo com o pensamento latino-americano. Em seus textos teóricos sobre teatro encontram-se referências a Grotowski, Stanislavski, Freud, de modo que a ênfase que estudiosos costumam dar unicamente à influência de Brecht sobre o encenador colombiano

\footnotetext{
${ }^{329}$ Cf. com o original: "Nuestro trabajo se sitúa más en el Mytos que en el Logos. Tratamos la obra, el texto escrito, como un Tema. El texto, como escritura, ha escogido, ha estabelecido su eje de selección-sustitución. Ha dicho esto y no aquello. Ha dejado de lado aquello que Brecht llama 'las alternativas muertas'. Brecht busca modos de recuperar estas alternativas especialmente en la actuación. Nosotros, en el trabajo de equipo y $\mathrm{ce}^{\wedge}$ nidos a él, buscamos estas alternativas muertas colectivamente, por emdio de las improvisaciones por analogia que realizan los equipos de actores. Brecht trabaja con un logos que abre la puerta al mytos, nosotros trabajamos con um mytos que abre la puerta al logos”. In Buenaventura, E. Diário de Trabalho (1984-1988), p.47.

${ }^{330}$ Buenaventura, E. “Esquema general...” In Materiales..., p. 345.
} 
acaba por, como afirma Diana Taylor, "limitar e obscurecer o alcance do legado de Buenaventura ao teatro latino-americano”331. Na leitura de Taylor, ela aponta a compreensibilidade dessa interpretação por parte dos estudiosos de Buenaventura, uma vez que seus esforços representariam uma forma de valorizar ou elevar a importância do trabalho de Buenaventura ao associá-lo com o de uma personalidade do porte de Brecht. Na verdade, Buenaventura recebeu sim grande influência de Brecht, mas também a de muitas outras tradições diversas e distintas como a que legou o esperpento, a commedia del arte, as peças do siglo de oro espanhol, o costumbrismo latino-americano e até, por que não, as reminiscências e resíduos das práticas pré-colombianas.

\section{Cronologia ${ }^{332}$ do TEC}

1955 - Enrique Buenaventura retorna à Colômbia, depois de uma excursão por vários países da América do Sul. É convidado para atuar na Escola de Teatro de Cali, fundada nesse ano.

1956 - Las Convulsiones, de Vargas Tejada.

1957 - Petición de mano, de Tchekov; Casamiento a la fuerza, de Moliere; El juez de los divórcios, de Cervantes; Misterio de los Reyes Magos, de Buenaventura.

1958 - Tio Cornejo Zapatero, de Buenaventura; Tres Pantomimas, Mondragon y Buenaventura; Las habladoras, de Cervantes; A la diestra de Dios Padre, adaptação do conto de Carrasquija por Buenaventura; Sueño de una noche de verano (Shakespeare).

1959 - El canto del cisne, de Tchekov; El amor de los cuatro coroneles, de Ustinov; El oso, de Tchekov; Historias para ser contadas, de Dragún; Pluff el fastamita, de Maria Clara Machado; Blancanieves y los siete enanos, adaptação de Buenaventura; El que recibe las bofetadas, de Andreiev; Larga cena de Navidad, de Wilder; El Monumento, de Buenaventura; Édipo Rey, de Sófocles.

\footnotetext{
${ }^{331}$ Taylor, D. 2003, p.

${ }^{332}$ Essa cronologia foi montada a partir de várias informações espalhadas nos escritos do dramaturgo e daqueles que escreveram sobre ele e sobre o TEC. De qualquer modo, informações extras foram acrescentada sobre um resumo sucinto da obra do TEC encontrado em Escenários entre dos mundos, p.331. Informações extras foram acrescentada a partir dos seguintes textos: VÁZQUÉZ-ZAWADZKI, op. cit. ;
} 
1960 - A la diestra de Dios Padre (segunda versão); La Cenicienta, de Buenaventura; La zorra y las uvas, de Figueiredo; Pinocho y los tres mosqueteros, de Buenaventura; La loca de Chaillot, de Giraudoux. Partipação no Festival de Teatro das Nações, Paris. Enrique Buenaventura fica em Paris durante esse ano, quando conhece o trabalho do Berliner Emsamble.

1961 - El enfermo imaginário, de Moliere; A casa de Bernarda Alba, de Lorca; A la diestra de Dios Padre (terceira versão); La bella durmiente del bosque, de Buenaventura; Entre bastidores y bambalinas (monólogos); Ali Babá y los quarenta ladrones, de Buenaventura; La Guariconga, de Buenaventura; Los amores de Pierrot, de Binoche; Jaxmin Rosse, de Buenaventura; Juan sin Tierra, de Buenaventura. La tragedia del rey Christophe. Excursão ao Equador.

1963 - Simbad el marino, de Buenaventura; Ha llegado um inspector, de Priessley; Barba Azul, de Buenaventura; Arsénico y encaje, de Kesselring; Réquiem por el padre Las Casas, de Buenaventura. Excursão à Venezuela.

1964 - La Celestina, de Rojas; La fierecilla domada, Shakespeare.

1965 - Panorama desde el puente, de Miller; El espantapájaro que queria ser rey, de Malfatti; Aladino y la Lâmpara maravillosa; Édipo Rey (Segunda versão).

1966 - Ubú rey, de Jarry; Las sirvientas, de Jean Genet.

1967 - La Trampa, de Buenaventura; Arlequin, servidor de dos patrones, de Goldoni; Los inocentes, de Buenaventura. Intercâmbio de diretores com a Casa de la Cultura. São suspensos os auxílios oficiais ao grupo em função da montagem de La Trampa, que desagradou autoridades. Deserção de vários integrantes.

1968 - Los papeles del infierno, de Buenaventura; Soldados, de Carlos José Reyes; El metro, de Jones.

1969 - El fantoche de Lusitânia, de Weiss; Seis horas de la vida de Frank Kulak, de Buenaventura. O grupo adquire uma nova sede.

1970 - Soldados (Terceira e quarta versão). Atuação no VIII Festival de Nancy e excursão pela França, Dinamarca, Itália e Bélgica. Primeiro seminário sobre o método da criação coletiva.

1972 - Excursão pelos Estados Unidos, Equador e México.

1973 - La denuncia (criação coletiva). Participação nos festivais de Manizales e San Juan. 
1974 - Participação no V Festival de Teatro Chicano e I Festival de Teatro Latinoamericano, no México.

1975 - A la diestra de Dios Padre (Quarta versão).

1976 - Atuação no IV Festiva de Teatro Universitário de L’Aquila, Itália, e excursão pela França. Vida y muerte del fantoche Lusitano, de Weiss e Buenaventura.

1977 - Excursão pela França, Polônia e Espanha. La orgia (Segunda versão). A Universidad del Valle outorga a Buenaventura o título de doctor honoris causa.

1978 - Atuação no VI Festival Cervantino, México.

1979 - Historia de una bala de plata, criação coletiva.

1980 - O texto de Historia de una bala... obtém o Premio Casa de las Américas de teatro.

1981 - Excursão ao Equador e participação no V Festival Internacional de Teatro de Caracas e o Festival Mundial de Teatro Amador, Mônaco.

1982 - Participação no III Festival de Teatro Latino de Nova York.

1983 - Ópera Bufa, criação coletiva.

1984 - La gran farsa de las equivocaciones, criação coletiva.

1985 - El maravilloso viaje de la mentira y la verdad, criação coletiva y A la diestra de Dios Padre (Quinta versão).

1987 - El encierro, criação coletiva. Temporada no Teatro Municipal General San Martín, de Buenos Aires. Apresentação no Festival Iberoamericano de Teatro de Cádiz.

1988 - Escuela para viajeros, de Buenaventura.

1989 - Cronica, de Buenaventura.

1991 - Proyecto piloto, de Buenaventura. 


\section{La Candelária: as alturas do vôo poético}

\section{Fundação do La Candelária}

"Em junho de 1966, num pequeno local que tinha se dedicado a atividades comerciais, leva a cabo uma atividade artística diferenciada: conferências, exposições de pintura, concertos, cinema e teatro". Assim começa o retrato feito por Gonzalo Arcila ${ }^{333}$ do momento incial da fundação do La Candelária, quando ainda se chamava Casa de la Cultura. Só em 1971, a Casa de la Cultura seria renomeada para La Candelária, “o que marca o início do período da produção coletiva. A partir deste ponto, García e seu grupo começam a se dedicar a trabalhos originais por meio da criação coletiva”334: Nosotros los Comunes (1971), La ciudad dorada (1973), Guadalupe años sin cuenta (1975), Diez dias que estremecieron el mundo (1978), Golpe de suerte (1980), Diálogo del Rebusque (1982). Depois de um recesso de 9 anos, a criação coletiva seria retomada só em 1988 com a estréia da peça El Paso (Parábola del camino). Nesse ínterim, seriam encenados três textos produzidos por integrantes do grupo, que seriam chamados de Trilogia sobre a Aculturação, são eles: La Tras-escena (1984) de Fernando Peñuela Ortiz, Corre, Corre, Carigüeta (1985) de Santiago Garcia, El viento y la ceniza (1986) de Patrícia Ariza. Retomada a criação coletiva, são estreadas após El Paso, La Trifulca (1991), En la Raya (1993).

\section{Personalidade de Santiago Garcia}

Formado em Arquitetura, apaixonado pelas Artes Plásticas, Santiago Garcia, nascido no ano de 1928 em Bogotá, se tornaria uma das principais referências do teatro

\footnotetext{
${ }^{333}$ La imagen teatra en La Candelária. Bogotá, ed. La Candelária, 1992, p.19.

${ }^{334}$ Baycroft, Bernard Kent. Brecht in colômbia: the rise of the new theatre. Michigan, 1986, p.139. Tese de Doutorado.
} 
colombiano e latino-americano. Santiago foi um dos mais originais discípulos de Seki Sano. Embora seja reconhecido principalmente como diretor/encenador, tornou-se também ator de teatro, tv e cinema. Ele mesmo conta suas aventuras pelo teatro quando ainda era criança, na entrevista concedida aos autores Duque Mesa e Prada Prada. Influenciado pelo pai que gostava de algo que eles chamavam de "Las Charadas", chistes, jogos de palavras, enigmas, García desenvolveu seu gosto pela cena nesse ambiente. Com cerca de 7 anos escreveu sua primeira obra de teatro, Sísi y Mimi, com duas primas. Ele mesmo conta esta aventura:

Sísi era uma menina que para tudo dizia "sim...sim”, era a encarnação mesma do otimismo, da generosidade, e Mími era a encarnação do egoísmo, "todo soy yo", "todo es para mí,", então: “meus sapatos novos, meu anelzinho novo", quer dizer, era a luta entre as duas crianças ( e isso porque não havia lido ainda Hegel), era um aobra... um jogo cômico!”. [...] e depois cheguei também a fazer parte do grupo de teatro do colégio, onde estudava $^{335}$.

De 1948 a 1951, estuda arquitetura na Universidade Nacional, seguindo depois para especialização na área, estudando um ano na Escola de Belas Artes em Paris, um ano em Londre e Veneza, cidade que representava a última tendência da área com as propostas da arquitetura orgânica de Frank Wright. Regressando a Colômbia, chegou a trabalhar numa empresa de arquitetura chamada "Esguerra y Herrera", mas seria por pouco tempo. Pouco depois de um ano nesse lugar, Santiago Garcia larga tudo para fazer teatro. Ao se inscrever para o curso de ator, no Instituto de Artes Cênicas fundada por Seki Sano, personalidade que é tratada na capítulo 1 deste trabalho, García estava selando um compromisso com a arte teatral para a vida toda. Fundador e diretor do La Candelária, o diretor angariou vários prêmios ao longo destes 40 anos de vida, atuou, dirigiu, escreveu peças teatrais, e criou uma das formas mais prestigiadas de processo de criação: a criação coletiva. Além disso, vem produzindo tarbalhos e reflexões teóricas sobre sua prática artística, construindo um acervo muito importante para a história do teatro colombiano e latino-americano, e possibilitando também a este teatro ser objeto de estudo e pesquisas.

Antes da criação do La Candelária, porém, Santiago García foi também um dos cofundadores do teatro El Búho, dedicado principalmente a montagens do Teatro do Absurdo.

\footnotetext{
${ }^{335}$ Duque Mesa, F.; Prada Prada, J. Santiago García..., op. cit., p.59.
} 
O diretor se refere ao "Búho" como um clube de amigos, um coletivo onde todos contribuíam com uma cota para a manutenção do espaço, uma sala pequena com cerca de 60 metros. As pessoas que freqüentavam o lugar eram basicamente pessoas vinculadas à universidade, professores, arquitetos, estudantes e amigos. O curioso é que o próprio Santiago Garcia assume que nesse período nem eles mesmos entendiam às vezes as peças do teatro do absurdo que montavam. Questionado sobre a importância do El Búho, García afirma:

A possibilidade de fazer outro teatro, de ir contra a tradição que vinha da Espanha, um teatro muito retórico, sério, [...] bastante pesado como espetáculo,e por sua vez, de irmos também contra o teatro de costumes, que tinha muito êxito junto as multidões como era o que faziam Luis Enrique Osório e Emilio Campos (Campitos), um teatro muito popular e muito importante em seu momento, mas que para nós não era o que interessava realmente. E, por outro lado, nosso propósito tratava além disso, [...] de nos colocarmos à ordem do dia sobre o que havia e se estava apresentando nos teatros de arte mais importantes de Paris, Nova York, Londres , Berlim e Roma, ou de qualquer capital do mundo. Palcos onde estavam apresentando as mesmas obras dos dramaturgos mais importantes desse tempo, e parecia-nos fundamental conhecer esses autores e essas obras por nossa própria conta, num outro país muito distinto, latino-americano, com outro olhar ${ }^{336}$.

Ainda durante esse período do el Búho, Santiago Garcia fez novas viagens à Europa para completar seus estudos sobre teatro. "Estive em Praga dois anos estudando teatro, na Universidade Carlos que tinha a Faculdade de Artes Musicais, e dentro desta seção havia programas de Teatro, Cinema, Marionete, porque o teatro e o cinema são considerados pelos tchecoslovacos como artes musicais” (p.127). Foi nesse período que teve contato com os trabalhos do encenador Otomar Krejca e do cenógrafo Joseph Svoboda. Sobre as obras que assistiu nesse período em Praga, foi perguntado a ele, quais o haviam marcado mais. Foram as obras de Tchekov, A gaivota, e mais tarde, As três irmãs. "Então, a linha de atuação era muito influenciada pelas propostas estéticas de Constantin Stanislavski?” Resposta: "La idea era um Stanislavski, porém mais próximo das propostas e concepções de Eugéne Vakhtángov, seu grande discípulo, isto é, mais para a versão espetacular do teatro, muito apoiado na técnica”.

\footnotetext{
${ }^{336}$ Duque Mesa, Fernando; Prada Prada, Jorge. Santiago García: El Teatro como Coraje. Bogotá, Investigación Teatral Ed., 2004, p.101.
} 
É preciso chamar a atenção para este fato em virtude de duas questões:

1. Foi visto no capítulo 1 o papel importante de Seki Sano para a profissionalização e para a modernização do teatro na Colômbia. Por meio da percepção e do aprendizado dele na Rússia, onde ficou cerca de 5 a 6 anos, ficou-se sabendo sobre a profunda influência de Meyerhold sobre a prática artística de Vakhtangov, que, além de lhe ter profunda veneração, admirava-o justamente por saber combinar as duas coisas: a vivência de Stanislavski com uma plasticidade espetacular do teatro teatral.

2. A ausência de referência ao nome de Meyerhold como um dos grandes mestres do teatro do século XX deve-se ao silêncio imposto sobre sua vida na Rússia depois de 1940. Nessa época em que Santiago Garcia esteve em Praga, certamente não se ouvia falar no nome de Meyerhold, mas o que ele viu ali no teatro, como ele próprio indica em seus comentários ao se referir a Vakhtangov, havia muito dos resultados alcançados pela pesquisa de Meyerhold. De forma indireta, outra vez, surpreende-se aqui o contato de Santiago Garcia com os pressupostos estéticos de Meyerhold.

Na seqüência, Santiago Garcia faz um estágio de seis meses no Berliner Ensemble, em Berlim, onde assiste a várias montagens do repertório clássico da companhia, dirigida por Brecht; e acompanha o processo de uma nova montagem Frau Flinz, dirigida por Manfred Wekwerth e Peter Palizsch e protagonizada por Helene Weigel. Depois de dirigir a ópera Los Hampones de Jorge Gaitán Duran em seu retorno a Bogotá em 1961, Santiago Garcia vai para o grupo que Fausto Cabrera estava dirigindo no Teatro Estúdio da Universidade Nacional, onde permanece de 1962 a 1964, num período que ele chama de primeira fase junto a Universidade Nacional. Em seguida, passa um ano viajando novamente: Actor's Studio em Nova York; depois Paris, Lion, onde encontra Roger Planchon; de novo a Paris, termina os estudos de teatro na Universidade do Teatro das Nações. Depois disso, teve lugar a segunda fase de García junto à Universidade Nacional, quando de sua volta a Bogotá em 1965, foi aí que ele montou a peça Galileu Galilei de Bertolt Brecht, que causou escândalo na cidade. 


\section{Sua Concepção Teatral}

A reintegração de Garcia ao Teatro El Buho, marca uma nova etapa no desenvolvimento do Nuevo Teatro, iniciando a transição de uma estética stanislavskiana a uma brechtiana (Maria Mercedes de Velasco, p.55)

É possível rastrear certas influências sobre o pensamento de Santiago Garcia por meio das referências bibliográficas utilizadas pelo autor em sua obra Teoria e Prática do Teatro. A gama diversificada de autores e citações deixa entrever um encenador culto, explorador, curioso, antenado com o seu tempo e aberto a idéias novas, venham estas de onde vier, desde que acrescentem alguma coisa ao seu trabalho. Desta forma, encontra-se neste livro referências a Stolovitch (p.12), Lênin (p.13), Hjelmslev (p.26), Picasso (p.27), Diego Rivera (p.38), cita Leonardo da Vinci; Rossi-Landi; claro Bertolt Brecht; cita Eisenstein; Shakespeare; F. Empson, “os sete tipos de ambigüidade” (p.56); Ercilla (p.56); Ariosto (p.56); Moris (p.59); Bakthin (p.64); Lottmann, “o problema da antropologia da cultura”, (p.64); Lanternari (p.64); Linton (p.65); Aristóteles (p.66); Marx (p.69).

O esquema do trabalho pode ser resumido do seguinte modo:

- plano do conteúdo: tema (substancia do conteúdo); argumento (forma do conteúdo);

- plano da expressão: linhas temáticas (substancia da expressão); linhas argumentais (forma da expressão)

Os passos em que se desenvolvem o processo de trabalho do grupo:

- motivação: valores subjetivos e intuitivos são fundamentais;

- pesquisa: etapa em que o grupo adota uma posição científica; divisão dos integrantes em pequenos grupos de investigação;

- terceira etapa: improvisação sobre o material “teatrável” coletado;

- definição das linhas temáticas;

- as linhas argumentais;

- etapa da montagem em dois planos: operativo e textual.

- improvisação analógica: preponderância de elementos metafóricos;

- procedimentos distintos: argumentos criados por situações ou por ações. 
Santiago Garcia demonstra cautela ao se referir à questão da ideologia na obra de arte em geral e na teatral em particular. Propõe uma "meditação mais profunda [sobre o tema] “do que uma simples e rápida tomada de posição”. (p.51).

A certa altura ele afirma:

Se entendemos o teatro por um lado como a confluência do que acontece no palco com o público e por outro como a representação dos conflitos dos homens num mundo que se transforma e é transformado pelo homem, esta interação deve sintetizar-se no que chamamos de imagem teatral". (p.52)

Alinha-se ao pensamento de Eisenstein de quem cita literalmente a seguinte proposição: "uma obra de arte concebida dinamicamente consiste no processo de ordenar imagens nos sentimentos e na mente do espectador". Assim, a questão da "imagem” e da criação de imagem cênica carregada de sentido sempre foi uma preocupação corrente em sua prática artística e produção teórica. Em sua obra, Teoria e práctica del teatro latinoamericano, encontra-se, por exemplo, a seguinte idéia:

\begin{abstract}
A imagem deve ser o resultado dialético da representação e da ação (imaginativa) que ela desencadeia nos sentimentos e na mente do espectador. Esta pode ser a ruptura de preconceitos, concepções do mundo e das relações dos homens ou reafirmações de ideologias ou conceitos de uma determinada sociedade num determinado momento histórico. (...) A imagem teatral não é, pois, a ideologia, nem um conceito, mas sua função é a de romper a ideologia ou a de reafirmar conceitos ou ideologias. (...) É uma forma ativa cujo conteúdo aciona (age) sobre os conteúdos da realidade. Se tomarmos como características sobressalentes de nosso movimento teatral nos últimos dez anos o fato de que os próprios artistas (atores e diretores) se apropriaram da obra teatral e, por conseguinte, de suas implicações na sociedade, é então necessário que nossa preocupação fundamental seja precisamente a de estudar a ação da imagem no processo da produção teatral e sua função em relação à ideologia da sociedade mutante e mutável ${ }^{337}$.
\end{abstract}

Os procedimentos no processo de formação de imagens parte inicialmente da análise do texto em três níveis: 1 . cotextual; 2. intertextual; 3. contextual.

${ }^{337}$ GARCIA, Santiago. Teoria e prática do teatro. São Paulo, Hucitec, 1988, p. 52. 
A nova imagem, “que já não está nem no artista nem na obra, está na relação entre a obra e o público. É produzida na representação e subsiste e se transforma depois dela. É fraca ou forte em razão direta ao impacto da relação palco-público. Sua função de transformação ou de consolidação das ideologias da sociedade depende da força que desencadeia o fato artístico, neste caso o encontro da obra com o público, fato que acontece num determinado tempo e espaço e somente nele. ${ }^{338}$ Santiago afirma que "as culturas produzem imagens (falsas u verdadeiras) que permitem um reconhecimento por parte dos indivíduos da sociedade”339. E tenta esclarecer a que se refere quando diz imagem: “o que propomos como IMAGEM é aquilo que o público vê através do personagem ou situação”, ${ }^{\text {,40 }}$, dando o exemplo de Rabelais. “A história proposta por Rabelais não é Gargântua, mas a que o leitor medieval descobria através de Gargântua: a grotesca gargalhada do povo como imagem irreverente e perturbadora de toda uma sociedade”341.

\section{Função da arte}

"No fundo, o artista é um intérprete dos sonhos, dos interesses e das esperanças de seu povo, e este trabalho, até hoje, foi feito intuitivamente"342. Afinal de contas, sabe-se bem que "a arte é um meio de que dispõe o homem e a sociedade para o conhecimento, a apreensão e a transformação da realidade.”343

\section{Função da arte latino-americana}

A partir da demonstração do exemplo da imagem produzida na tragédia grega, entendida como mecanismo de estabilização da sociedade, Santiago García detecta a função da arte na América Latina: "No caso da nossa arte latino-americana a procura dessa imagem na qual se possa reconhecer o homem americano foi a tarefa central dos nossos mais eminentes artistas.”344 Isto é, encontrar uma imagem artística que traduza o homem americano e a sua identidade. “Trata-se de produzir imagens que sejam capazes de conter

\footnotetext{
${ }^{338}$ GARCIA, Santiago, 1988, p.53.

${ }^{339}$ GARCIA, Santiago, 1988, p.66.

${ }^{340}$ GARCIA, Santiago, 1988, p.67.

${ }^{341}$ GARCIA, Santiago, 1988, p.68.

${ }^{342}$ GARCIA, Santiago, 1988, p.62.

343 GARCIA, Santiago, 1988, p.66.

${ }^{344}$ GARCIA, Santiago, 1988, p.67.
} 
uma realidade vasta, histórica (aspecto diacrônico) e ao mesmo tempo de colaborar neste processo de transformação da sociedade enquanto se vai conformando a identidade nacional (aspecto sincrônico)”345.

A grande questão é “como encontrar esta identidade no cruzamento violento de influências, dentro do caos que tenta impor uma pseudocultura servida pelos meios de comunicação de massa?" 346 Mas, com relação a este aspecto nacional, de que forma poderíamos encará-lo sem cair em estreitas posições chauvinistas ou populistas? ${ }^{347 \text {, }}$

Santiago Garcia afirma que 1959 é o ano em que vários grupos de teatro independente surgem. "Um dos primeiros foi o Teatro do Mocho, composto pelos egressos dos ensinamentos do senhor Seki Sano. Para Garcia, não havia teatro comercial em Colômbia, quando os primeiros impulsos começaram a sinalizar o desenvolvimento do teatro no país. Ter o espaço físico próprio equivalia em ter em suas mãos os meios de produção. Santiago Garcia afirma categoricamente que o impulso para a construção de uma dramaturgia nacional foi resultado de pressão do seu próprio público que ele qualifica de proletário, a classe mais dinâmica da sociedade.

\section{Método de trabalho coletivo do La Candelária}

Uma dos fatos mais impressionantes ao se ter contato com o método de trabalho do grupo é a sua incansável disposição para a pesquisa. Em longa parceria com a CCT, o grupo se lança à investigação, abordando os mais distintos temas e autores da prática teatral. Junte-se a isso, o longo percurso de Santiago Garcia e o La Candelária, cujo acúmulo de experiências tem o poder de tornar mais rápida algumas fases do processo de criação. Ele comenta a longa duração no processo de criação da primeira obra de criação coletiva do grupo: Nosotros los comunes. Em virtude de se tratar de uma montagem clássica do repertório do Nuevo Teatro, pode ser pertinente dedicar algumas páginas a essa experiência originária do La Candelária.

\footnotetext{
${ }^{345}$ GARCIA, Santiago, 1988, p.69.

${ }^{346}$ GARCIA, Santiago, 1988, p.66.

${ }^{347}$ GARCIA, Santiago, 1988, p.69.
} 


\section{Nosotros los comunes - a primeira criação coletiva do La Candelária}

Trata-se assumidamente de um tipo de peça de teatro documentário ${ }^{348}$ como o entende Patrice Pavis. O assunto apresentado evoca um dos episódios mais comentados da história de um país que na época nem se chamava Colômbia, mas Reino de Nova Granada. Assim era conhecida nos velhos tempos coloniais quando ainda abarcava Venezuela e Equador dentro de suas fronteiras. O episódio em questão é o da "Revuelta de los Comuneros”, de 16 março de 1781, também denominado “Rebelião do Povo”. O vice-reino de Nova Granada, criado em 1717 para garantir a defesa de Cartagena e da costa, foi o palco de um dos ataques mais surpreendentes às autoridades do vice-reino, com apenas 75 soldados $^{349}$, tornando-se ainda um antecedente relevante na posterior independência do país.

Como afirma Diana Bonett, o movimento “del Común” poderia ser definido “hoje como uma empresa massiva de desobediência civil que buscava protestar contra as reformas impostas pela Coroa espanhola”. ${ }^{350}$

Essas reformas espanholas estavam inscritas no contexto da tentativa da Coroa de "reconquistar o controle da administração colonial [para] depois criar novas instituições de governo". ${ }^{351}$ Nas primeiras décadas do século XVIII, a Espanha se restringia a "repelir ... incursões estrangeiras a seu território e consolidar sua posse nas fronteiras ameaçadas”. 352 Estava tão enfraquecida que, “durante a Guerra de Sucessão, precisou pedir proteção de navios de guerra franceses para escoltar até a metrópole a frota do tesouro de Veracruz”. 353 As conseqüências desse enfraquecimento foi que

...em todas as províncias do império, o governo passara a ser dominado por um pequeno grupo de interesses na colônia, formado pela elite crioula advogados, grandes proprietários rurais e clérigos -, por alguns funcionários da Península com longo tempo de serviço e pelos grandes

\footnotetext{
348 "É o teatro que só usa, para seu texto, documentos e fontes autênticas, selecionadas e "montadas" em função da tese sociopolítica do dramaturgo,” segundo Patrice Pavis em seu Dicionário de Teatro. Ele seria também o herdeiro do drama histórico.

${ }^{349}$ Branding, D. A., op. cit. p. 403.

${ }^{350}$ BONETT, Diana. “Estalla la Revuelta de los comuneros”. In.: http://www.colombiamania.com/historia/ index_historia/04_las_fundaciones_y_poblamiento/0010_revuelta_comuneros.html, acesso em 18/01/07.

${ }^{351}$ BRANDING, D. A. “A Espanha dos Bourbons e seu Império Americano”. In BETHELL, Leslie (org.). História da América Latina: A América Latina Colonial I, vol.1, São Paulo: Edusp; Brasília, DF: Fundação Alexandre Gusmão, 1998, p. 402.

${ }^{352}$ BRANDING, D. A. “A Espanha dos Bourbons e seu Império Americano”, op.cit., p. 400.

${ }^{353}$ Branding, D. A., op. cit., p. 400.
} 
comerciantes de importação. (...) Muito mais que os delegados formais da coroa, eram o clero, o secular e o regular, que exerciam a verdadeira autoridade dentro da sociedade, atuando como líderes intelectuais e espirituais da elite e como conselheiros e guardiães das massas. ${ }^{354}$

Em meados do século XVIII, o regime dos Bourbons tentou empreender uma revolução administrativa no império, promovendo uma modernização do sistema de produção com vistas a aumentar a arrecadação. A Espanha precisava urgentemente de divisas para saldar dívidas contraídas com a derrota na Guerra dos Sete Anos contra a GrãBretanha, que também resultou nas perdas de Havana e Manila, tomadas pelos britânicos. A insolvência da Espanha aliada a uma má administração estava levando o reino à beira da falência. "Foi nesse momento que os ministros de Carlos se voltaram para o programa de reformas elaborado no Nuevo Sistema de Gobierno Econômico para la América, de Campillo e Cossío (1743), um manuscrito que circulava desde 1743...”, em que se defendia “um retorno à prática da visita geral”, seguida da “criação de intendências permanentes”. 355

E assim deu-se início a uma paulatina substituição da elite crioula na ocupação de cargos burocráticos de importância por funcionários vindos da Espanha. ${ }^{356}$ Iniciativa que ficou conhecida como a "Reconquista das Américas". Além desta, outras medidas foram tomadas, dentre as quais, constam "o recolhimento mais eficiente de alcabalas (taxas de consumo), a supervisão rigorosa dos pagamentos de tributos e as restrições ao cultivo de fumo aliados aos altos preços.

Essas medidas entraram em choque direto com os próprios vice-reis progressistas que haviam sido enviados às colônias, como se pode averiguar no seguinte relato de Germán Arciniegas:

Começam a florescer na América as figuras dos grandes vice-reis da última metade do século XVIII. Homens de ação, aventureiros, sim (...) mas amigos das artes e das letras, supreendidos em sua virgindade espanhola por leituras apressadas da enciclopédia francesa e empurrados para uma linha progressista por obra e graça dos ministros de Carlos III. (...) Em suas bagagens, vêm livros proibidos, idéias que irrompem no mundo escolástico da Colônia para corrompê-lo. (...) Os novos vice-reis não sabem, na realidade, o explosivo que levam entre suas mãos quando

\footnotetext{
${ }^{354}$ Branding, D. A., op. cit. p. 400.

355 Branding, D. A., op. cit. p. 402.

${ }^{356}$ BONETT, Diana. “Estalla la Revuelta de los comuneros”. In.: http://www.colombiamania.com/historia/ index_historia/04_las_fundaciones_y_poblamiento/0010_revuelta_comuneros.html, acesso em 18/01/07.
} 
começam a abrir leito às idéias francesas, ou, mais simplesmente, às de seu monarca Don Carlos III. ${ }^{357}$

Don Manuel Antonio Flórez, o novo vice-rei de Nova Granada, "fará que ... floresçam as artes, que a educação se expanda e que as riquezas se multipliquem”. Quando desembarcou em Cartagena, no novo reino, cheio de entusiasmo para transformá-lo na pequena jóia da Coroa, deparou-se com o completo abandono: as duas únicas vias que conduziam de Cartagena à capital estavam quase destruídas, tomadas pela vegetação. “A Colônia tinha paralizado toda [sua] expressão vital”, o continente estava morto, “a capital [se encontrava] em grande estado de abandono e pobreza, a educação pública insuficiente”, enquanto "o exército sem corpo nem vigor” não tinha força para impor ordem alguma e nesse caos e marasmo restavam "os corregedores fazendo o papel de ladrões, os índios rebeldes e desordeiros se revoltando cada vez mais, os trabalhadores e artesãos da cidade sem escola nem disciplina”, as universidades apenas como projeto e uma imprensa paupérrima; em uma palavra, “tudo vencido pelos vícios dos administradores antigos.”358

Em face desse estado de coisa, foram grandes os empenhos dos novos vice-reis liberais para propiciar o desenvolvimento social e econômico nas colônias. Poucos anos depois, uma nova ordem chegaria das metrópoles representada na figura dos visitadoresgerais. Era a guinada da Espanha derrotada na guerra. Esses “visitadores” tinham o propósito de impor novas leis, pautadas principalmente nos aumentos de impostos, causando choque entre estes e os vice-reis das colônias. Em Nova Granada, por exemplo, “o regime fiscal foi ajustado para conseguir uma arrecadação mais rigorosa dos impostos sobre a produção e o consumo de tabaco e cachaça. Elevou-se a cobrança de impostos da alcabala, registrando rigorosamente a entrada e saída dos produtos”. ${ }^{359}$ De acordo com Diana Bonett,

Con el régimen de intendencias se transformó la organización administrativa y espacial de las colonias, se limitó la autoridad de los virreyes, y las tierras comunales fueron recortadas o expropiadas y las comunidades indígenas trasladadas. En la ejecución de estas reformas tuvo un lugar importante la presencia de Juan Francisco Gutiérrez de

\footnotetext{
357 “Los Virreyes”, trecho da obra Los comuneros, compilado por Juan Gustavo Cobo Borda em sua obra intitulada América Ladina: Germán Arciniegas. México, Fondo de Cultura Económica,1993, p. 46-47.

${ }^{358}$ Germán Arciniegas. “Los Virreyes”, op. cit. , p. 52-53.

${ }^{359}$ BONETT, Diana. "Estalla la Revuelta de los comuneros”, op. cit. p. 1.
} 
Piñeres, visitador general y portador del nuevo paquete reformista enviado desde España. ${ }^{360}$

Essa nova política espanhola submetia à exclusão amplos grupos sociais. Mas o que detonou mesmo a mobilização desses grupos e sua forte reação foram as novas leis referentes à elevação dos valores dos impostos sobre as vendas ${ }^{361}$. Essa medida gerou uma revolta, que tendo começado no povoado de Socorro foi se ampliando até conseguir aglutinar em torno de si mais de 60 povoados: crioulos, mestiços, índios, negros livres, uniram-se numa sublevação jamais vista. Tudo começou quando no dia 16 de março de 1781, num gesto de rebeldia, Manuela Beltrán e outros rasgaram o edital sobre os modos e os preços de como deviam ser pagos os impostos. Nesse dia, concentraram-se na praça homens e mulheres, “vociferando que não pagariam as contribuições, desembocando num grande protesto sob o lema "Viva el rey, pero no queremos pagar la Armada de Barlovento”, ${ }^{362}$ Três líderes se destacam nesse movimento como representantes cada um deles de sua etnia: Ambrosio Pisco, dos índios; José Antonio Galán ${ }^{363}$, dos mestiços; Francisco Berbeo e Salvador Plata, como representantes dos interesses da elite crioula. Ajuntaram-se ao movimento, “além do conjunto popular, os terra-tenentes e pequenos proprietários que viram ameaçadas suas possibilidades de crescimento ante a nova política fiscal."364

Obviamente, o desfecho foi trágico.

E nesse ponto, vale a pena uma pequena digressão para confrontar duas leituras históricas distintas que tornam explícitas as escolhas políticas dos produtores dos textos: o primeiro é o texto de D. A. Brading e o segundo é o artigo de Diana Bonett ambos já citados neste trabalho. A certa altura, lê-se em Brading a seguinte informação:

\footnotetext{
${ }^{360}$ BONETT, Diana. “Estalla la Revuelta de los comuneros”, op. cit. p. 1.

${ }^{361}$ Como diz Branding, “o tema comum a todas essas rebeliões populares era o ressentimento contra as novas taxas impostas pelo Estado Bourbon. (p. 442).

362 BONETT, Diana. “Estalla la Revuelta de los comuneros”, op. cit. p. 1.

363 “...fue un prócer colombiano del siglo XVIII. Nacido en Charalá (Santander), participó en la revolución de los Comuneros, revuelta que dió inicio al proceso independentista colombiano. Murió descuartizado en Santafé de Bogotá. Una de sus frases célebres que se encuentra en la plaza de Guaduas(Cundinamarca) es: "En el nombre de mis mayores y de la libertad, ni un paso atras, siempre adelante, y lo que fuere menester...sea!" In:

${ }^{364}$ BONETT, Diana. “Estalla la Revuelta de los comuneros”, op. cit. p. 2.
} 
...na Nova Granada, a revolta comunero foi detida pela hábil negociação do arcebispo e do vice-rei interino Antonio Caballero y Góngora, que cancelou os decretos fiscais mais impopulares e concedeu anistia aos líderes do movimento (grifo nosso).

Quatro equívocos neste pequeno trecho: 1) O nome de Antônio Caballero y Góngora é o nome do arcebispo que procedeu à negociação das capitulaciones com os líderes do movimento comunero e não do vice-rei como o texto sugere; e 2) o nome do vice-rei na ocasião era Manoel Antônio Flórez ; 3) o visitador geral enviado pela Espanha era Juan Francisco Gutiérrez de Piñeres, e não Antônio Caballero y Góngora como aparece no texto; e 4. os líderes do movimento não foram anistiados como se afirma, mas executados e esquartejados, tendo parte de seus corpos espalhados em vários pontos da cidade.

Por ignorância ou por deliberação, equívocos como este em obra tão importante dedicada à história da América Latina só contribuem para aumentar o obscurecimento dessa história. Além dos equívocos, certas escolhas com relação ao vocabulário usado deixam evidentes que, mais do que compromisso com a verdade, o autor está comprometido com a sua ideologia de classe. Quando se refere à “hábil negociação do arcebispo” na resolução do conflito comunero, trata-se mais de traição do que habilidade, uma vez que nenhum dos pontos dessa negociação foi cumprida e, logo após, passado o perigo, tudo voltou a ser como antes, com o aumento dos impostos e tudo.

Em oposição ao exposto por Brading, Bonnet afirma que “con 'capitulaciones’ o arcebispo Antonio Caballero y Góngora terminou traindo (grifo nosso) a José Antonio Gailán (um dos líderes do movimento) e aos comuneros.” A igreja, na pessoa do arcebispo Caballero y Góngora, foi a grande representante do governo no diálogo com os revoltosos. Das negociações resultaria um documento chamado exatamente "Capitulaciones”, cujos 35 pontos atendiam as solicitações dos populares, mas que não seriam evidentemente cumpridas. Abrindo assim um precedente que se tornaria modelo amplamente utilizado tanto no que se refere "à traição de acordos tratados entre diferentes forças sociais” quanto o relacionado à brutalidade na forma de punição dos movimentos sociais, independente do regime de governo, como bem assinala Diana Bonett, que segue afirmando que: "los líderes insurgentes fueron fusilados y descuartizados y sus miembros exhibidos en varias plazas, 
para escarmiento de la población. Los que se salvaron fueron enviados en galeras a cárceles españolas.”365

Embora não se trate de "versões" em Brading, mas de equívocos mesmo, ainda assim o caso faz pensar em Otávio Paz, onde se lê que "toda versão é provisória: o texto muda sem cessar (embora talvez sempre diga o mesmo), e daí que, de tempos em tempos, descartem-se certas versões em favor de outras que, por sua vez, tinham sido descartadas antes."366.

Depois dessa longa digressão sobre um evento do período colonial colombiano, cabe perguntar qual a sua razão de ser? Não deveria proceder à análise da peça Nosotros los comunes, a partir da ciência de que se trata da primeira obra de criação coletiva do grupo La Candelária? Pois bem, o fato é que essa pequena descrição histórica traz em si o próprio enredo e trama da peça, dado o grau de comprometimento com os fatos históricos dessa primeira montagem do La Candelária. Além disso, fica evidente na peça uma orientação para a comprensão dos fatos similares à leitura proposta por Diana Bonett, contrariando versões oficiais ou equivocadas como a de Branding, por exemplo.

Convém, entretanto, chamar atenção para a originalidade da concepção dessa obra, tanto com relação à dramaturgia quanto no que concerne à encenação. Antes de mais nada trata-se de uma obra aberta, nos moldes do canovaccio da Commedia dell'arte, como o próprio Santiago Garcia afirma:

Aqui o texto funcionava como a trama da commedia dell'arte italiana... sua escrita é aberta... É um plano fundamentalmente oral. Produzido instataneamente pelo ator em cada representação mas submetido sem sombra de dúvidas a regras determinadas pelo próprio grupo ao longo de todo o processo de criação da obra. ${ }^{367}$

Mas a originalidade a que se faz referência acima está relacionada mais propriamente a certa peculiaridade da concepção desse teatro documentário, no qual "os protagonistas da história da 'revolta dos comuns' não aparecem fisicamente em cena”, mas vão se configurando como personagens ausentes, ou melhor, presentes por meio do impacto que seus comportamentos vão produzindo na massa “comunera”. Ou seja, a história da

\footnotetext{
365 BONETT, Diana. “Estalla la Revuelta de los comuneros”, op. cit. p. 2.

${ }^{366}$ Labirinto da Solidão, p. 241.

${ }^{367}$ GARCIA, Santiago. Teoria e prática do teatro, p. 37.
} 
“Revuelta de los Comuneros” é escrita a partir do ponto de vista do "povo”. Tratava-se de “um acontecimento histórico (...) bastante conhecido e que [tinha] em Antônio Galán uma figura ...mística das lutas populares na Colômbia”368.

Ainda que não tenha sido bem recebida pela crítica da época, a peça teve ampla aceitação do público. Eduardo Gomez critica o ponto de vista por meio do qual é apresentada esse evento histórico. Para ele, um povo alienado não era um povo que pudesse julgar historicamente a seus caudilhos, nem as figuras da opressão espanhola ou crioula. Para ele, esses eventos históricos, “ao ser vistos através do povo, é o povo dos comuns quem impõe sua imagem ao espectador”, descartando assim qualquer interpretação acadêmica da história. O que se configuraria em último caso como um dispositivo de idealização desse povo bem como um ato de mistificação da história colombiana. E paradoxicalmente tudo se daria em nome da “concientização das massas”.

Nesse sentido, o crítico aponta diversos problemas na dramaturgia e na encenação da obra. Com relação à dramaturgia, ele afirma: 1. sua tendência a uma "concepção populista”; 2. idealização ingênua das massas populares; 3. obscurecimento dos fatos históricos em sua leitura mistificadora. Com relação à encenação e interpretação: 1. o imediatismo da improvisação dos atores; 2. "lances confusos" provocados pela "simultaneidade das intervenções”, tornando-os ininteligíveis; 3. "renúncia ao diálogo" produzindo uma “anarquia coloquial”; 4. um certo naturalismo “pintoresquista”, com “gesticulação incessante”; entre outros problemas. Entretanto, o próprio crítico relativiza todas essas observações ao chamar atenção para a necessidade de se considerar a "novidade do experimento”, justificando assim “as debilidades da montagem”. Destaca como bons momentos aquelas "cenas mais meditadas" como a que "la madre de una heroina despista a los guardas, os “vigorosos e precisos informes históricos dos entreatos, alguns dos poemas de Nelson Osório e o figurino. ${ }^{369}$

Não obstante, como atesta o próprio grupo,

La respuesta del público, no solo del final, como a veces se mide el resultado, sino de toda la duración del espectáculo dejó al grupo conmovido. Era la primera vez que muchos sentíamos en lo más

\footnotetext{
${ }^{368}$ GARCIA, Santiago. Teoria e prática do teatro, p. 113.

369 “'Nosotros los Comunes': el peligro latente del populismo”. In: Watson Espener, Maida; José Reyes, Carlos. Materiales para una historia del teatro en Colombia, p. 403-406.
} 
profundo del alma el sentido verdadero del teatro. Su entrañable relación con el público popular que siente y vibra cuando tocan su lenguaje interno, cuando se habla en su idioma subterráneo, cuando se llega a sus raíces. ${ }^{370}$

Para a criação deste montagem teatral, o grupo de Santiago Garcia "realizou estudos da realidade econômica, política e social da época e de seus possíveis nexos com o contexto atual”, do início dos anos setenta (1971), reunindo um material a partir do qual fizeram improvisações, primeiro analógicas e depois homológicas. Do que surgiu, selecionaram “episódios, situações e imagens” com os quais armaram um argumento. ${ }^{371}$ A cada representação os atores improvisavam a partir de uma pauta fixada nos ensaios. Com essa peça, “La Candelária atuou em sindicatos, praças e escolas”. ${ }^{372}$ Além disso, “o grupo viajou ao Chile a convite da Central Única dos Trabalhadores e ofereceu cerca de 30 representações em Santiago, Arica, La Serena, Salvador, Antofagasta, Calama, Linache e Copiapo". 373

\footnotetext{
${ }^{370}$ GARCIA, Santiago. Prólogo do texto “Cinco obras de creación colectiva: teatro La Candelaria”. In: http://www.banrep.gov.co/blaavirtual/letra-c/cinco/prologo.htm, acesso em abril de 2005.

${ }^{371}$ ESPINOSA DOMÍNGUEZ, Carlos. “La Candelaria: vivir para el teatro”. In.: Escenarios de dos mundos:, p. 334.

${ }^{372}$ ESPINOSA DOMÍNGUEZ, Carlos. “La Candelaria: vivir para el teatro”, p. 334.

${ }^{373}$ ESPINOSA DOMÍNGUEZ, Carlos. "La Candelaria: vivir para el teatro, p. 334.
} 


\section{SOBRE A IMAGEM}

\section{Sobre a idéia de imagem poética}

Para abordar conceitualmente a noção de imagem poética, buscou-se reflexões da semiótica, da análise da pintura e da análise cinematográfica, apoiada em autores tais como Tzvetan Todorov, Henry Suhami, Octavio Paz, Lucia Santaella e Winfried Nöth, Gaston Bachelard, Serguei Eisenstein, Alfredo Bosi, Andrei Tarkovski, entre outros. Além disso, foi necessário destacar o papel da imagem no âmbito das artes, levando em conta seus diversos e distintos modos de produção como a imagem visual nas artes plásticas, a imagem verbal na poesia, a imagem mental na música, imagem áudio-visual no cinema e a imagem "total" no teatro.

O campo de ação da presente investigação parte do sintagma conceitual imagem poética como instrumento por meio do qual se opera a análise da produção artística dos grupos teatrais em foco. Só depois de munida de seu delineamento, definição e compreensão poder-se-á prosseguir na abordagem do objeto de estudo. Tome-se então o primeiro termo do sintagma: o que se entende afinal por imagem?

\section{Imagem}

Partindo-se da compreensão do senso comum, tem-se, desde o radical “imag-" as seguintes acepções:

antepositivo, do lat. imágo,ìnis 'semelhança, parecença, representação, retrato (pictórico, escultórico, plástico, verbal); fantasma (em poesia); imagem, comparação (em retórica)', conexo com o gr. eikôn - ver icon(i/o)-; donde, em lat.imp., o v. imagìnor,áris,átus sum,ári (depoente) 'imaginar, representar na imaginação; sonhar, devanear em sonho' (na voz ativa em Aulo Gélio, sII: imagìno,as,ávi,átum,áre 'apresentar uma imagem [com relação a um espelho]'), imaginabìlis,e 'imaginável', imaginális,e 'que é em imagem', imaginarìus,a,um 'que faz retratos (em pintura ou escultura); imaginário, fingido, falso, simulado, fictício', imaginatìo,ónis 'imaginação, imagem, representação, visão; pensamento, idéia, meditação; ilusão', ademais de imaginósus,a,um (em Catulo, sI a.C.); imágo supõe talvez, referem Ernout e Meillet, um v. com rad. *im-, do qual teria derivado como vorágo de vóro, prov. com a intermediação de voráx; esse rad. está presente no freqüentativo imitor,áris,átus sum,ári (imitáre em lat. arcaico) 'procurar reproduzir a imagem, imitar, 
arremedar, modelar-se por, copiar, trasladar, assemelhar-se a; contrafazer, simular, fingir, falsificar', com vários der.: imitátor,óris 'o que imita, imitador: o que contrafaz, arremeda', imitatìo,ónis 'ação de imitar, imitação, cópia, traslado', imitabìlis,e 'que pode ser imitado, contrafeito; imitável', inimitabìlis,e 'inimitável', lat.tar. imitatívus,a,um 'imitativo, de imitação', cópia...etc. ${ }^{374}$

Como se pode verificar na citação do Houaiss, a etimologia da palavra remonta ao latim “imágo”, com seu conexo grego, “ícone” (eíkon), que se referem de uma maneira geral à representação e à imagem, ou à faculdade de imaginar, sonhar e devanear; ou de imitar e copiar. De certo modo, estas acepções gerais permancem no fundo das definições propostas por estudiosos de campos diferentes do conhecimento. Com base na obra de Lucia Santaella e Winfried Nöth, é possível proceder a uma primeira distinção fundamental no universo das imagens, dividindo-as em dois domínios:

o primeiro é o domínio das imagens como representações visuais: desenhos, pinturas, gravuras, fotografias e as imagens cinematográficas, televisivas, holo e infográficas” (...). O segundo é o domínio imaterial das imagens na nossa mente. Neste domínio, imagens aparecem como visões, fantasias, imaginações, esquemas, modelos ou, em geral, como representações mentais ${ }^{375}$.

Obviamente, como os autores alertam, estes dois “domínios da imagem não existem separados, pois estão inextricavelmente ligados já na sua gênese” ${ }^{\text {”76 }}$. A cada um destes dois domínios, caberiam um conceito e uma ciência distintos: a semiótica se dedicaria ao estudo das representações (dos signos) visuais, ou seja, ao lado “perceptível” da imagem, enquanto a ciência cognitiva se debruçaria sobre as representações mentais, seu lado imaterial. Com relação a esta imagem mental, objeto da ciência cognitiva, diversos modelos de explicação de sua formação foram apresentados, especialmente suas relações com o sistema lingüístico. Entre eles, o modelo da "codificação dual [apresenta-se como] uma teoria mediadora das duas posições da psicologia cognitiva. De acordo com ela, (...) existem dois sistemas mentais separados, nos quais informação verbal e visual é processada

\footnotetext{
${ }^{374}$ In: Dicionário Eletrônico Houaiss da Língua Portuguesa.

${ }^{375}$ Conf. Lucia Santaella; Winfried Nöth. Imagem: cognição, semiótica, mídia. São Paulo: Iluminuras, 2005, p.15. Santaella traça nessa obra um panorama histórico do desenvolvimento do conceito, apontando os alcances e limites das diversas considerações sobre a questão da imagem.

${ }^{376}$ Lucia Santaella; Winfried Nöth. Imagem..., op. cit., p.15.
} 
dominantemente. Entretanto, no processamento cognitivo de imagens, não somente o sistema visual, mas também o sistema verbal está envolvido.

Ainda que Peirce ${ }^{377}$ distinga entre imagem e ícone, a similaridade do significado dos dois termos tem sua força na irmandade que suas respectivas etimologias latina e grega parece conter. Segundo Santaella,

Peirce dividiu os ícones em ícones puros e signos icônicos ou hipoícones, que se subdividem em imagem, diagrama e metáfora. (...) Um exame detido dos diferentes aspectos do ícone (...) revela que há três níveis de iconicidade que se apresentam em seis subníveis, que vão do ícone puro à metáfora. Essa distribuição em níveis é subtancial para a resolução de muitos impasses teóricos enfrentados pelas variadas modalidades das imagens: perpectivas, óticas, gráficas, menatias e também as verbais.

Mesmo que essa distinção entre imagem e ícone responda a uma estratégia de classificação “em princípios lógicos”, visando a construção de um “mapa de orientação para leitura precisa e discriminatória das leis que comandam o funcionamento de todos os tipos possíveis de signo”378, certa confusão se instaura na análise de Santaella ao serem utilizados como sinônimos, mesmo depois de evocada a distinção peirciana entre os dois termos. No interesse desse trabalho não faz muito sentido evocar as várias “modalidades da imagem” que a Semiótica de Peirce desenvolveu e que Santaella atualiza em seu trabalho. Para o que interessa no presente estudo, basta a compreensão da imagem principalmente inserida no contexto da produção artística. Sem entrar na discussão referente ao grau de validade e eficácia dos conceitos semióticos, a evocação do nível de complexidade atingido por esta disciplina denota a crescente importância do estatuto do "visível”, das imagens pictóricas ou visuais alcançadas no curso do século XX. Ou melhor, na "interface” entre imagem e palavra, de acordo com as conclusões a que Santaella agudamente chegou: “o código hegemônico deste século não está nem na imagem, nem na palavra oral ou escrita, mas nas suas interfaces, sobreposições e intercursos, ou seja, naquilo que sempre foi do domínio da poesia” ${ }^{379}$ (p.69).

\footnotetext{
${ }^{377}$ In Imagem, op. cit., p.60.

${ }^{378}$ Santaella; Nöth, Imagem, op. cit., p.59.

${ }^{379}$ Santaella; Nöth, Imagem, op. cit., p.69.
} 
Para uma classificação eficaz do processo evolutivo da produção de imagens, parece suficiente evocar a proposta dos três paradigmas, que Santaella e Nöth trazem no final de sua obra: o paradigma pré-fotográfico, o fotográfico e pós-fotográfico:

[1]O primeiro paradigma nomeia todas as imagens que são produzidas artesanalmente, quer dizer, imagens feitas à mão, dependendo, portanto, fundamentalmente da habilidade manual de um indivíduo para plasmar o visível, a imaginação visual e mesmo o invisível numa forma bi ou tridimensional. Entram nesse paradigma desde as imagens nas pedras, o desenho, a pintura e gravura até a escultura. [2] O segundo se refere a todas as imagens que são produzidas por conexão dinâmica e captação física de fragmentos do mundo visível, isto é, imagens que dependem de uma máquina de registro, implicando necessariamente a presença de objetos reais preexistentes. [3] (...) O terceiro paradigma diz respeito às imagens sintéticas ou infográficas, inteiramente calculadas por computação. Estas não são mais, como as imagens óticas, o traço de um raio luminoso emitido por um objeto preexistente - de um modelo captado e fixado por um dispositivo foto-sensível químico (fotografia, cinema) ou eletrônico (vídeo), mas são a transformação de uma matriz de números em pontos elementares (os pixels) visualizados sobre uma tela de vídeo ou uma impressora.

Percebe-se a partir destes postulados que o advento da fotografia provocou uma verdadeira revolução paradgmática no que se refere às produções das imagens visuais. Além desta classificação paradigmática de Santaella, recorre-se ainda a outra distinção básica, a crer na leitura de Anne Ubersfeld da semiótica peirciana, referente aos signos. Ubersfeld lembra que no campo da representação, os signos, verbais ou não, são em princípio todos sinais, na medida em que são teoricamente todos intencionais...”380. Evocando a terminologia de Pierce, os signos são classificados em índices, ícones, e símbolos:

o índice está numa relação de contigüidade com o objeto (por exemplo, fumaça-fogo) ao qual remete; o ícone mantém uma relação de semelhança com o objeto denotado (semelhança em certos aspectos, como é o caso do retrato). [...] Quanto ao símbolo, segundo Peirce, tratase de uma relação preexistente e submetida às condições socioculturais entre dois objetos; por exemplo, o lírio e a brancura ou a inocência ${ }^{381}$.

\footnotetext{
${ }^{380}$ Ubersfeld, Anne. Para ler o teatro. São Paulo: Perspectiva, 2005, p.11.

${ }^{381}$ Ubersfeld, Anne. Para ler o teatro, op. cit., p.11.
} 
Mas para se prosseguir na captação das implicações sobre a idéia de imagem, convém situar todo o sistema semiótico de Peirce junto com as abordagens de Santaella como sendo da ordem de primeiro grau, como o é todo o sistema lingüístico no campo dos sinais verbais. Para além desse nível, situam-se as reflexões sobre imagem e representação no contexto da criação artística, na qual se trataria sempre de produção de sentido da ordem de segundo grau; como a que aparece na teoria cinematográfica de Eisenstein por exemplo.

Nesse ponto, surge outro problema: o da definição de representação, que também é pertinente ao campo da criação teatral. Do ponto de vista da Semiótica, Santaella e Nöth recuperam, na obra recorrentemente citada, as variações e os usos do termo desde a escolástica medieval, cotejando e contrapondo nuances da terminologia em autores como Tomás de Aquino, e outros mais recentes como Rosenberg, Dretske, Peirce, Mario Bunge, Goodman, passando por Guilherme de Ockham e Wittegenstein, entre outros. "As tentativas da delimitação do conceito são variadas, mas, freqüentemente imprecisas”. Assim, encontram-se definições de representação como sinônimo de "signo", como de “relação sígnica”, de "referência” e “função de apresentação”, e, por fim, de "signo icônico"382. Outro nível da questão semiótica refere-se à confusão da dicotomia “representação/apresentação”. As discussões filosóficas e psciológicas acabaram envolvendo tais conceitos por meio da abordagem de Husserl e Heidegger, propondo definições que por fim influenciaram o estudo semiótico nas obras de Max Bense, por exemplo, como é indicado por Santaella e Nöth. Estas questões referentes à imagem no âmbito da semiótica, porém, interessam ao presente trabalho apenas de uma forma marginal. Na obra dos autores aqui citados encontra-se um panorama histórico do desenvolvimento do conceito de imagem desde a antigüidade grega aos dias atuais. Reforçando o dito anteriormente, esse debate semiótico interessa ao campo do teatro apenas na medida em que uma representação teatral produz imagens continuamente. Obviamente, distintas da imagem produzida na pintura ou no cinema, mas em última instância imagens. Em vista disto, o objetivo desta abordagem semiótica é o de situar a dupla complexidade referente aos termos “representação” e "imagem” no campo da arte. Por isso, da explanação

\footnotetext{
${ }^{382}$ Lucia Santaella; Winfried Nöth. Imagem..., op. cit., p.16.
} 
de Santaella e Nöth interessa reter o que parece ser uma definição mais acabada da idéia de representação, definida a partir da proposta "da fase tardia” de Peirce, que eles citam na seguinte passagem:

representação (...) é o processo da apresentação de um objeto a um intérprete de um signo ou a relação entre o signo e o objeto: "Eu restrinjo a palavra representação à operação do signo ou sua relação com o objeto para o intérprete da representação”. A fim de delimitar os conceitos de representação e signo, ele introduz o termo representamen para o veículo do signo: "Quando é desejável distinguir entre aquilo que representa e o ato ou relação de representar, o primeiro pode ser chamado de 'representamen', o último de 'representação' "383.

Chama-se a atenção aqui para a importância de se reter desta definição a referência ao "para o intérprete da representação", o que inclui no teatro, por exemplo, o papel fundamental do espectador ou receptor da obra, que, a propósito, concentrará boa parte da pesquisa e da reflexão no curso do século $\mathrm{XX}$ por parte dos principais nomes dos encenadores e teatrólogos, sendo considerado já desde os primórdios, com Meyerhold em primeiro lugar, como o quarto criador da obra teatral.

$\mathrm{N}$ teoria fílmica de Eisenstein, a ampliação dos conceitos de “imagem” e “representação” é proposta a partir da distinção de cada um dos termos, no contexto da definição de montagem - propriedade fundamental na criação cinematográfica eisensteiniana. No primeiro capítulo, "Palavra e imagem”, de $O$ sentido do filme, encontrase a definição de montagem do seguinte modo:

A representação $A$ e a representação $B$ devem ser selecionadas entre todos os aspectos possíveis do tema em desenvolvimento, devem ser procuradas de tal modo que sua justaposição - isto é, a justaposição desses próprios elementos e não de outros, alternativos - suscite na percepção e nos sentimentos do espectador a mais completa imagem do próprio tema ${ }^{384}$.

A referência às noções de representação e imagem no interior desta definição faz com que Eisenstein se proponha em seguida a realizar a demarcação entre elas por meio de diversos exemplos. Ele apresenta três exemplos de processo de criação de imagens na vida

\footnotetext{
${ }^{383}$ Peirce, Charles. Collected Papers. Vols.1-6 ed. Hartshorne, Charles \& Weiss, Paul; vols. 7-8 ed. Burks, Arthur W. Cambridge, Mass.: Harvard Univ. Press., 1931-1958. Apud (Santaella; Nöth, 2005, p.17)

${ }^{384}$ Eisenstein, S. O sentido do filme. Rio de Janeiro: Zahar, 2002, p.18.
} 
e na arte por meio de diferentes representações da idéia de tempo: 1. a do tempo cronológico: o relógio; 2. a de uma determinada hora, como a imagem das cinco horas da tarde (estas duas criações da vida prática); e, 3. a da imagem da meia noite, por meio da representação das doze badaladas (na criação literária). A precisão da demonstração eisensteiniana pode ser conferida nas citações destes exemplos a seguir:

Tomemos um disco branco de tamanho médio e superfície lisa, dividido em 60 partes iguais. A cada cinco partes é colocado um número na ordem consecutiva de 1 a 12. No centro do disco são fixadas duas varas de metal, que se movimentam livremente sobre sua extremidade fixa, pontudas nas extremidades livres, uma do tamanho do raio do disco, a outra um pouco mais curta. Deixemos a extremidade livre da vara pontuda mais longa marcar o número 12, e a da mais curta, consecutivamente, apontar para os números 1, 2, 3 e assim por diante, até o número 12. Isto implicará uma série de representações geométricas de relações consecutivas das duas varas de metal, expressadas nas dimensões 30, 60, 90 graus, e assim por diante, até 360 graus.

Porém, se o disco dispuser de um mecanismo que movimenta uniformemente as varasa metálicas, a figura geométrica formada em sua superfície adquire um significado especial. Agora não é simplesmente uma representação, é uma imagem do tempo ${ }^{385}$ (grifos do autor).

Nesse exemplo, Eisenstein observa a fusão completa entre representação e imagem suscitada na percepção corrente, de modo que "apenas sob condições especiais distinguimos a figura geométrica, formada pelos ponteiros do relógio, do conceito de tempo"386. Tentando deslindar o processo pelo qual "algo tem de acontecer com a representação, algo mais tem de ser feito com ela” para que se torne uma imagem perceptível $^{387}$, Eisenstein recorre à eficácia do exemplo da imagem das cinco horas da tarde, que é suscitada por meio de um grupo de representações associadas a uma determinada hora:

Suponhamos, por exemplo, que o número seja cinco. Nossa imaginação está treinada para responder a este número recordando cenas de todos os tipos de acontecimentos que ocorrem nesta hora. Talvez o chá, o fim de uma jornada de trabalho, o começo da hora do rush no metrô, talvez lojas fechando as portas, ou a peculiar luminosidade do final da tarde... Em qualquer dos casos, automaticamente nos lembraremos de uma série de cenas (representações) do que acontece às cinco horas.

\footnotetext{
${ }^{385}$ Eisenstein, S. O sentido..., op. cit., p.18-19.

${ }^{386}$ Eisenstein, S. O sentido..., op. cit., p.19.

${ }^{387}$ Eisenstein, S. O sentido..., op. cit., p.19.
} 
A imagem das cinco horas é composta de todas essas representações particulares $^{388}$ (grifo do autor).

Nesse exemplo das cinco horas, o processo de formação de imagens fica muito claro. Com relação à participação do universo psíquico humano nesse processo, Eisenstein observa que entra em funcionamento as "leis de economia da energia psíquica”, por meio das quais “ocorre uma “condensação”, isto é, a cadeia de representações de múltiplos fragmentos da realidade desaparece e uma conexão entre o número e nossa percepção do tempo ao qual corresponde é estabelecida instantaneamente.

O interesse de Eisenstein no deslindamento dessa “'mecânica’ da formação de uma imagem (a partir de representações) é justificado por ele em razão de “...os mecanismos de sua formação na realidade [servir] de protótipo do método de criação de imagens pela arte” (p.20). "Entre a representação de uma hora no mostrador do relógio e nossa percepção da imagem dessa hora, há uma longa cadeia de representações vinculadas aos aspectos característicos distintos dessa hora”, que é por sua vez reduzida a um mínimo, a fim de que apenas o início e o fim do processo sejam percebidos. (p.20).

O que distinguiria este processo de formação de imagens na "prática da vida” do da “prática da arte” estaria no que Eisenstein identifica como um “deslocamento da ênfase”. Na vida, a ênfase recairia no resultado, passando rapidamente pelo primeiro estágio de reunião de fragmentos de imagens; enquanto na arte, para se conseguir um resultado, haveria de "dirigir toda a sutileza de seus métodos para o processo". Assim, "no método real de criação de imagens, uma obra de arte deve reproduzir o processo pelo qual, na própria vida, novas imagens são formadas na consciência e nos sentimentos humanos”. Esta condição da criação na arte valeria, na concepção de Eisenstein, "sempre e em qualquer parte, não [importando] qual a forma artística em discussão”,389. O terceiro exemplo que Eisenstein evoca para ilustrar uma imagem do tempo criada agora no âmbito da arte é colhido na Literarura: trata-se de uma passagem de Bel Ami de Maupassant. "É a cena em que George Duroy (...) está esperando no fiacre por Suzanne, que concordou em fugir com ele à meia-noite” (p.22). Não há necessidade de reproduzir toda a citação que

\footnotetext{
${ }^{388}$ Eisenstein, S. O sentido..., op. cit., p.19.

389 Todas as citações deste período referem-se à mesma obra de Eisenstein, p. 20-22. Nesse ponto, o autor recorre ao trabalho do ator como exemplo para ilustrar sua concepção.
} 
Eisenstein faz dessa passagem de Maupassant, bastaria um pequeno trecho, aquele que concentra a sua análise. Siga-se-lo:

[...]Um relógio distante deu doze badaladas, depois um outro mais perto, depois dois juntos, depois um último, muito longe. Quando este acabou de tocar, pensou: “Acabou-se. Deu tudo errado. Ela não virá”. Estava entretanto resolvido a ficar, até de manhã. Nestes casos é preciso ser paciente $\left[\ldots . . .{ }^{390}\right.$

De acordo com Eisenstein, nessa passagem, “doze horas da noite só é a hora cronométrica num grau mínimo, e é, num grau máximo, a hora na qual tudo (ou de qualquer modo, muito) está em jogo ('Acabou-se (...) Ela não virá.')”. Seguindo de perto a análise de Eisenstein com suas próprias palavras, tem-se que:

Nesse exemplo, (...) quando Maupassant quis gravar na consciência e nas sensações do leitor a qualidade emocional da meia-noite, não se limitou a mencionar que primeiro bateu a meia-noite e depois uma hora. Ele nos obrigou a experimentar a sensação da meia-noite, fazendo com que as doze horas batessem em vários lugares e em vários relógios. Combinados em nossa percepção, estes grupos individuais de doze badaladas se transformam numa sensação geral da meia-noite. As representações separadas se transformaram em uma imagem (grifos em itálico do autor; grifo em sublinha nosso) $)^{391}$.

Neste momento, Eisenstein volta ao ponto de partida que gerou toda a reflexão sobre a demarcação de sentido entre representação e imagem: "Isto foi inteiramente feito por meio de montagem"(grifo nosso). É o tal princípio de montagem que, na arte, reúne e organiza as representações de fragmentos da realidade de modo a transformá-las em uma determinada imagem. Ainda com relação a este exemplo de Maupassant, Eisenstein identifica em sua estrutura textual, o que ele diz ser "o mais requintado estilo de roteiro de montagem: “Este badalar de relógios, registrados a várias distâncias, é como a filmagem de um objeto a partir de diferentes posições da câmera e repetida numa série de três diferentes enquadramentos: 'plano geral', plano médio', 'plano de conjunto’”392. A conclusão de Eisenstein na análise dessa passagem é a de que a reprodução das diversas badaladas reais de relógio à meia noite não tinha nada a ver com uma tentativa de descrição "naturalista de

\footnotetext{
${ }^{390}$ Guy de Maupassant, Bel Ami. [Tradução brasileira de Clovis Ramalhete. São Paulo, Livraria Martins, 1953.] apud Eisenstein, op. cit., p.23.

${ }^{391}$ Eisenstein, op. cit., p.23.

${ }^{392}$ Eisenstein, op. cit., p.23.
} 
Paris à noite”, mas a “ênfase insistente na imagem emocional da 'meia-noite' fatal, não a mera informação: 'zero hora'”393.

Eisenstein não se limita a colher exemplos de aplicação do princípio de montagem em romance, ele o identifica também na interpretação do ator, tanto na construção externa dos gestos e movimento quanto na construção do universo interior, daquilo que motiva a atitude ou o gesto exterior do ator: "Mesmo se sua interpretação for tomada de um único ângulo (ou mesmo de uma única poltrona da platéia de um teatro), apesar disso - num caso bem sucedido - a interpretação terá a qualidade de “montagem”. Idenfifica-o também nas notas de Da Vinci para a pintura (de um quadro não realizado): um verdadeiro "roteiro de filmagem, com “cenas audiovisuais incomuns”; mas também em uma infinidade de poemas retirados da Literatura clássica, fonte inesgotável de imagens poéticas para Eisenstein. Isso o leva a afirmar a existência de um princípio da montagem em geral, válido para todas as modalidades de arte, cuja expressão no cinema seria apenas uma das formas particulares de sua manifestação.

Mesmo que Eisenstein não faça referência em nenhum momento ao sintagma imagem verbal em seu texto, é essa a categoria de imagem fornecida por ele ao analisar a estrutura de poemas, ilustrando mais uma vez nesse processo, a aplicação do princípio de montagem como método de construção de imagens utilizado pelos poetas. Deste modo, ele confirma a tendência dominante de se considerar o poema como imagem. Imagem construída a partir da linguagem, das relações entre palavras num verso, enfim, da articulação das palavras como disse Bosi.

Até este ponto, foi feita uma abordagem de forma esquemática sobre a questão da imagem em geral. Mas, para a eficácia da idéia de imagem poética como um conceito operativo na análise da imagem teatral do Nuevo Teatro, há que se partir da distinção entre “Poética” e "poética”, ou seja, distinção entre sua acepção substantiva e adjetiva.

\footnotetext{
${ }^{393}$ Eisenstein, op. cit., p.23.
} 


\section{Poética e poética}

O substantivo "Poética” está mais relacionado aos estudos literários e mais precisamente à abordagem do poema ${ }^{394}$ e é nesse sentido substantivado que é tratado nas obras de Tzvetan Todorov ${ }^{395}$, Henry Suhamy ${ }^{396}$, Vladimir Maiakovski ${ }^{397}$, Alfredo Bosi ${ }^{398}$, Jakobson, entre outros. Suhamy parte da definição de poética, que ele chama de “provisória”, como “designativa, ao mesmo tempo, da arte e da ciência da poesia”. A certa altura, ele faz referência à confusão entre os termos em suas acepções substantiva e adjetiva:

será útil distinguir entre a Poética e o poético, indicando que há forçosamente zonas comuns aos campos semânticos que cobrem essas duas noções, e laços orgânicos, ainda mais por que no masculino o adjetivo utilizado como substantivo designa uma qualidade geral, elevada à altura de um conceito, o que acentua a semelhança. A Poética trata, pelo menos em parte, do poético, isto é, explora um veio, ou produz um corpus, que a consciência intelectual ou mesmo a percepção imediata caracterizam como relacionados com o poético ${ }^{399}$.

Para Suhamy, “a Poética criou o poético”. Ou seja, “a criação literária é anterior à noção de qualidade poética” ${ }^{400}$. Todorov, por sua vez, entende Poética como a análise "das condições gerais do nascimento do sentido”401 ou, noutro lugar, afirma “(...) Poética se define como uma ciencia da literatura ${ }^{402}$ : (...) São os aspectos especificamente literários da literatura, aspectos que só ela possui [...]”. Ou nos postulados de Jakobson, lê-se que: “o objeto da ciência literária não é a literatura, mas a literaridade, isto é, o que faz de determinada obra uma obra literária"403.

A finalidade de semelhante estudo não é mais a de articular uma paráfrase, um resumo racional da obra concreta, e sim a de propor uma teoria da estrutura e do funcionamento do discurso literário, uma teoria

\footnotetext{
${ }^{394}$ A maioria dos livros sobre "Poética”, refere-se ao universo da literatura.

395 Todorov, T. Estruturalismo e Poética. São Paulo, Cultrix, 1973.

${ }^{396}$ Suhamy, H. A Poética. Rio de Janeiro, Zahar, 1988.

${ }^{397}$ Maiakovski, V. Poética. São Paulo, Global, 1984.

${ }^{398}$ Bosi, A. O ser o tempo da poesia. São Paulo, Cultrix, 1997.

${ }^{399}$ Suhamy, H. A Poética, op. cit., p.11.

${ }^{400}$ Suhamy, H. A Poética, op. cit., p.12-13.

401 Todorov, A Poética, p. 32.

402 Todorov, A Poética, p.127.

${ }^{403}$ Jakobson, R. (Questions de poétique, 1973), apud Todorov, op. cit., p.127.
} 
que apresente um quadro tal dos possíveis literários, que as obras literárias existentes apareçam como casos particulares realizados ${ }^{404}$.

Nessa tradição, a obra fundadora da Poética com teoria da literatura foi a do próprio Aristóteles, que descreveu as propriedades do discurso das tragédias e comédias gregas, exercendo grande influência sobre todo o teatro ocidental. O termo se origina também do verbo grego poieu, substantivo poiêsis que significa criar e “criação”.

Franklin Rodríguez ${ }^{405}$, cujo artigo traz no título esse conceito, resume o termo baseado nas proposições da teoria literária de Todorov e Ducrot, segundo os quais:

O termo "poética” pode ser entendido em três níveis distintos:

a) o que designa a tradição como toda teoria interna da Literatura;

b) o que designa a poética do autor que se baseia na seleção pessoal dentro de todas as possibilidades literárias (temática, composição, estilo etc.);

c) o que se refere ao código normativo que constrói uma escola literária sobre a base de um complexo de regras práticas, cuja utilização se torna obrigatória. ${ }^{406}$

Todorov, no final de sua obra Estrutura e Poética, aqui citada, aponta para uma ampliação do conceito de poética como ciência de todo tipo de textos, não apenas os verbais. Com suas próprias palavras, enuncia que: “[...] hoje não há mais nenhuma razão para reservar somente à literatura o tipo de estudos que se cristalizou na Poética: é preciso conhecer 'como tais' não apenas os textos literários, mas todos os textos; não apenas a produção verbal, mas todo simbolismo" ${ }^{\text {407 }}$.[Grifos do autor].

No âmbito da arte teatral, esse aspecto normativo da Poética e "seus pressupostos metodológicos" parece terem se tornado "bastante fora de moda, anacrônicos". Só no decorrer do século XX é que esta Poética foi se tornando menos normativa, mais descritiva, até mesmo, estrutural, passando a examinar as peças e a cena como sistemas artísticos

\footnotetext{
404 Todorov, A Poética, op. cit., p.15.

405 “Apuntes...”, op. cit., p.

406 Todorov; Ducrot, 1973 apud Franklin

${ }^{407}$ Todorov, A Poética, op. cit., p.129-130.
} 
autônomos ${ }^{408}$. Pavis se refere aqui ao campo de estudo da Semiologia Teatral surgida nos anos 60, influenciada pela semiótica e estruturalismo francês.

Mas a poética que interessa neste trabalho é aquela suposta em sua acepção adjetiva, de difícil apreensão, entre outros fatores, devido ao seu caráter considerado um tanto subjetivo. Mesmo assim, é esse dado poético, relacionado à criação da poesia em cena, que importa desmaranhar. Para começar, nada mais estimulante do que evocar a agudeza de espírito de um Georg Lukács quando, também sob o ponto de vista da teoria literária, faz a seguinte pergunta: “o que é que torna poéticas as coisas na poesia épica?”. Eis aqui sua própria resposta:

O palco e a orquestra, os camarins e os bastidores são em si mesmos, objetos inanimados, sem interesse e sem poesia. Continuam a sê-lo ainda quando se enchem de seres humanos e só com os acontecimentos nos quais se realizam as experiências da evolução destes homens é que eles adquirem a capacidade de provocar em nós emoções poéticas" ${ }^{409}$.

“As coisas só têm vida poética”, continua Lukács, “enquanto relacionadas com acontecimentos de destinos humanos. Por isso, o verdadeiro narrador épico não as descreve e, sim, conta a função que elas assumem nas vidas humanas” ${ }^{410}$. Essa idéia é perfeitamente aplicável ao teatro em geral, e o latino-americano em particular. Assim, caberia perguntar: o que torna poéticas as coisas no teatro latino-americano? Que se deixe a pergunta em suspenso por ora. Voltar-se-á a ela mais adiante.

Buscar-se-á antes o deslindamento do sentido do termo "poético”. Se, em primeiro lugar, o termo poético tem a ver com poesia, o que é poesia então? Em seu sentido mais comum e geral, poesia pode significar, além da “arte de compor ou escrever em versos”, “poder criativo”, (...) pode significar aquilo que desperta o sentimento do belo ou aquilo que há de elevado ou comovente nas pessoas ou coisas”411. Atente-se, de preferência, para este último significado referente “...àquilo que há de comovente nas pessoas ou coisas”. Não se trata aí de entender poesia como um gênero literário, mas naquele sentido próximo

\footnotetext{
${ }^{408}$ Patrice Pavis. Dicionário de Teatro (São Paulo,1999), p. 296.

${ }^{409}$ G. Lukács. “Narrar ou descrever?”, in Ensaios sobre Literatura (Rio de Janeiro, 1945), ps. 71-75;90.

${ }^{410}$ G. Lukács. "Narrar ou descrever”, op. cit.

${ }^{411}$ De acordo com o Dicionário Eletrônico Houaiss da Língua Portuguesa.
} 
ao observado por Andrei Tarkovski ${ }^{412}$ em sua meditação sobre cinema, Esculpir o tempo: “Quando falo de poesia, não penso nela como gênero. A poesia é uma consciência do mundo, uma forma específica de relacionamento com a realidade. Assim, a poesia torna-se uma filosofia que conduz o homem ao longo de toda a sua vida”413. O artista afinado com essa filosofia “é capaz de perceber as características que regem a organização poética da existência. Ele é capaz de ir além dos limites da lógica linear, para poder exprimir a verdade e a complexidade profundas das ligações imponderáveis e dos fenômenos ocultos da vida" ${ }^{414}$.

Pode-se compreender melhor agora o sentido a que se refere Lukács em suas definições. A seu modo, ele também se refere o tempo todo a esse mundo humano. Quando ele diz que “a essência corpórea do homem também só adquire vitalidade poética na relação com outros homens, na influência que exerce sobre eles”, fica mais clara essa referênca à “vitalidade poética” como aquela poesia que traspassa o mundo dos homens e suas mútuas relações. Em vista disso, o que pode tornar o teatro, supõe-se, uma obra de arte poética, no nível do texto verbal: é a palavra poética; e, no nível do texto espetacular, são os gestos, as atitudes dos personagens em cena, suas relações com outros personagens, ou seja, a trajetória e principalmente a transformação que o passar do tempo imporá aos personagens, ou ainda o que o evolver da ação fará emergir do comportamento deles, enfim, aquela matéria que se constroe a partir do mundo vivido. A situação exposta no início da peça será diferente ao cabo do espetáculo. E a combinação, de uma determinada maneira, de todos estes elementos em cena poderá suscitar uma imagem que na apreensão do espectador será percebido como algo comovente ou poético, isto é, uma poesia concreta.

Lukács aconselha:

O grande escritor deve observar a vida com uma compreensão que não se limite à descrição da superfície exterior dela e nem se limite à colocação em relêvo, feita abstratamente, dos fenômenos sociais (ainda que tal colocação seja justa): cumpre-lhe captar a relação íntima entre a necessidade social e os acontecimentos da superfície, construindo um entrecho que seja a síntese poética dessa relação, a sua expressão concentrada. ${ }^{415}$

\footnotetext{
${ }^{412}$ Cineasta russo (1932-1986).

413 Tarkovski, Andrei. Esculpir o tempo. São Paulo: Martins Fontes, 1990, p.18.

${ }^{414}$ Tarkovski, Andrei. Esculpir o tempo, op. cit., p.19.

${ }^{415}$ G. Lukács. “Narrar ou descrever?”, op. cit.,
} 
Tarkovski confirma como se segue:

Um artista pode alcançar a ilusão de uma realidade exterior, e obter efeitos cuja naturalidade os faça em tudo semelhantes à vida, mas isto será ainda muito diferente de examinar a vida que está sob a sua superfície. [...] Há alguns aspectos da vida humana que só podem ser reproduzidos fielmente pela poesia ${ }^{416}$.

Mas, para o artista, “examinar a vida que está sob a sua superfície”, ou "construir um entrecho que seja a síntese poética” do que está sob e do que está na superfície, há que se entregar à imaginação poética, operação a que Bachelard identifica como a geradora dessa síntese ou imagem poética. Bachelard considera “a imaginação como uma potência maior da natureza humana” (p.18). Eis aqui sucintamente seu raciocínio:

Com sua atividade viva, a imaginação desprende-nos ao mesmo tempo do passado e da realidade. Abre-se para o futuro. À função do real, orientada pelo passado tal como mostra a psicologia clássica, é preciso acrescentar uma função do irreal igualmente positiva, como procuramos estabelecer em obras anteriores. Uma enfermidade por parte da função do irreal entrava o psiquismo produtor. Como prever sem imaginar? ${ }^{417}$ (Grifos do autor).

Esta forma de encarar a imaginação humana como uma forma de conhecimento parece profundamente revolucionária. Não é mais considerada aqui meramente engano dos sentidos, mas sobretudo como uma forma de despertamento dos múltiplos automatismos que recalca o homem moderno e contemporâneo. "Com a poesia a imaginação coloca-se na margem em que precisamente a função do irreal vem arrebatar ou inquietar - sempre despertar - o ser adormecido nos seus automatismos”418. As duas funções do psiquismo humano, a função do real e do irreal, trabalhariam conjuntamente para o alargamento da percepção e assimilação do mundo, podendo desembocar nessa capacidade de ir além dos limites da lógica linear e entender as características que regem a organização poética da existência, para evocar de novo as palavras de Tarkovski. Essa tese da fenomelogia bachelardiana está de par com as descobertas mais recentes do campo da neurociência, para a qual, o lado esquerdo e direito do cérebro, embora atuem dominantemente em áreas

\footnotetext{
${ }^{416}$ Tarkovski, Andrei. Esculpir o tempo, op. cit., p.19-31.

${ }^{417}$ Bachelard, Gaston. A poética do espaço. São Paulo: Martins Fontes, 2005, p.18.

${ }^{418}$ Bachelard, Gaston. A poética do espaço, op. cit., p.18.
} 
distintas, não podem operar isoladamente ${ }^{419}$. É com base no apoio mútuo de informações entre eles que cada um encontra sua resposta aos inumeráveis estímulos e afetações advindos do mundo exterior.

Com base nesses breves apontamentos sobre a natureza do elemento poético, aplicável em todos os campos da arte para além da pura criação de versos e poemas propriamente ditos, esmerar-se-á em seguida na apuração da idéia de imagem poética.

\section{Imagem poética}

A imagem poética transporta-nos à origem do ser falante.

Gaston Bachelard

Como defini-la? De que modo captá-la? Qual a operação que o artista há de fazer para alcançá-la em sua obra? Tanto Paz quanto Bosi entendem-na apenas como relacionada ao universo da feitura de poemas. Eisenstein e Bachelard recorrem à poesia (como gênero literário) para ilustrar sua exposição sobre os princípios da criação imagética. Todorov, embora se refira à Poética em sua acepção substantiva como Ciência da Literatura, deixa no final grande abertura para a Poética como modelo de explicação de quaisquer sistemas simbólicos. Seguindo esse caminho de Todorov, a aplicação do termo poética em seu sentido adjetivo também vale para sistemas simbólicos outros, diversos do universo do poema. Para além do gênero literário, a poesia, como diz Tarkovski, é uma consciência do mundo. Detectar como ela se origina e que tipo de operação o artista faz para erigi-la é o tema de que se ocupará nesse momento. Os alcances das reflexões de Bosi, de Paz e de Bachelard são as principais referências. Ainda que todos eles se remetam ao universo do poema, é perceptível sua validade para as outras modalidades artísticas, como se verá mais adiante.

${ }^{419}$ Referência neorociência. 
Embora se trate de uma idéia arredia à explicação, quando ela é vivenciada pelo "leitor” na experiência da fruição estética, não há quem não a compreenda. Seu ser manifesto se dá por inteiro. O ato poético, com sua lógica própria,

Deixe que fale os poetas:

A imagem artística é sempre uma metonímia em que uma coisa é substituída por outra, o menor no lugar do maior. Para referir-se ao que está vivo, o artista lança mão de algo morto; para falar do infinito, mostra o finito. Substituição... não se pode materializar o infinito, mas é possível criar dele uma ilusão: a imagem ${ }^{420}$.

Substituições que geram ressonâncias e repercussões nas profundezas do ser, a imagem poética emerge "na consciência como um produto direto do coração, da alma, do ser do homem tomado em sua atualidade”, segundo a abordagem de Bachelard. Em sua obra, ele se propôs a identificar o início da imagem numa consciência individual, analisando a obra de vários poetas, para assim "reconstituir a subjetividade das imagens e a medir a amplitude, a força, o sentido da transubjetividade da imagem". De que forma "o aparecimento de uma imagem poética singular pode reagir - sem nenhuma preparação - em outras almas, em outros corações, apesar de todas as barreiras do senso comum, de todos os pensamentos sensatos [...] ?” Ao esforçar-se para dar resposta a essa questão da "transubjetividade” da imagem, Bachelard descobre o caráter variacional da imagem poética. "Não é, como o conceito, constitutiva”. "Ao nível da imagem poética, a dualidade do sujeito e do objeto é irisada, reverberante, incessantemente ativa em suas inversões”. É na criação de uma imagem poética que a alma afirma a sua presença. “A imagem poética está sob o signo de um novo ser" ${ }^{421}$. Nesse sentido último, pode-se perceber com clareza a convergência entre a consideração da imagem poética de Bachelard e Paz. Quando Paz distingue entre linguagem e poema, pode-se ler o seguinte: “a linguagem indica, representa; o poema não explica nem representa, apresenta. Não alude à realidade; pretende - e às vezes o consegue - recriá-la. Portanto, a poesia é um penetrar, um estar ou ser na realidade”,422. Para Paz, "o poeta faz algo mais do que dizer a verdade; cria realidades que

\footnotetext{
${ }^{420}$ Tarkovski, Andrei. Esculpir o tempo, op. cit., p.42.

${ }^{421}$ Bachelard, G., op. cit., p.4-42.

${ }^{422}$ Paz, O., op. cit., p.50.
} 
possuem uma verdade: a de sua própria existência. As imagens poéticas têm a sua própria lógica"423.

Foi visto no tópico 1 os procedimentos de Eisenstein para a criação de imagens na arte. Ele demonstrou as semelhanças desses processos com o que ocorre na formação de imagens na vida prática comum. Paz tenta fazer uma demonstração semelhante a partir da relação com um objeto, acompanhe-se-lo: “Quando percebemos um objeto qualquer, este se nos apresenta como uma pluralidade de qualidades, sensações e significados. Esta pluralidade se unifica, instantâneamente, no momento da percepção”, cujo “elemento unificador” é o sentido. “As coisas possuem um sentido”. A intencionalidade está presente até "mesmo no caso da mais simples, casual e distraída percepção”. De modo que, o sentido é tanto o fundamento da linguagem “como também de toda apreensão da realidade”. E aqui uma idéia similar da de Eisenstein: “À semelhança da percepção ordinária, a imagem poética reproduz a pluralidade da realidade e, ao mesmo tempo, outorga-lhe unidade”. Daqui para diante, Paz vai tentar iustrar o que vai distinguir o ofício do artista da prática comum dos homens: “Todas as nossas versões do real - silogismos, descrições, fórmulas científicas, comentários de ordem prática, etc. - não recriam aquilo que pretendem exprimir. Limitam-se a representá-lo ou descrevê-lo",424. Mas,

se vemos uma cadeira, por exemplo, percebemos instantaneamente sua cor, sua forma, os materiais com que foi construída, etc. A apreensão de todas estas notas dispersas não é obstáculo para que, no mesmo ato, nos seja dado o significado da cadeira: o de ser um móvel, um utensílio. Mas se queremos descrever nossa percepção da cadeira, teremos que ir aos poucos e por partes: primeiro sua forma, depois sua cor e assim sucessivamente até chegar ao significado. No curso do processo descritivo foi-se perdendo pouco a pouco a totalidade do objeto. A principio a cadeira foi apenas forma, mais tarde uma certa espécie de madeira, e finalmente puro significado abstrato: a cadeira é um objeto que serve para sentar-se. No poema a cadeira é uma presença instantânea e total, que fere de um golpe a nossa atenção. $O$ poeta não descreve a cadeira: coloca-a diante de nós. Como no momento da percepção, a cadeira nos é dada com todas as suas qualidades contrárias e, no ápice, o significado. Assim, a imagem reproduz o momento de percepção e força o leitor a suscitar dentro de si o objeto um dia percebido.

\footnotetext{
${ }^{423}$ Paz, O., op. cit., p.45.

${ }^{424}$ Todas as citações entre aspas deste período referem-se à mesma obra de Paz, op. cit., p.46.
} 
A partir dessa diferença entre linguagem e imagem, percebe-se como o poeta consegue por meio da linguagem construir imagens que se dão por inteira, instantaneamente à nossa compreensão, valendo-se da intensidade da tensão criada no momento em que a linguagem poética tenta escapar do eixo linear e seqüencial característicos dela mesma. Similarmente ao exemplo concreto da cadeira, tome-se um outro exemplo, aqueles constitutivos do cojunto de percepções humanas. Do mesmo modo, a origem e a totalidade de todo sentir humano se perderiam na tentativa de serem traduzidas pela língua, devido à necessidade de acomodá-las na cadeia sintagmática da linguagem. Além disso, muitas impressões humanas permanecem como impressões humanas, fugidias, caindo no total esquecimento. Aqui opera com agudeza a sensibilidade do verdadeiro poeta. Como diz Tarkovski, "muitas coisas [...] ficam em nossos corações e pensamentos como sugestões não concretizadas”425, ou percepções esmaecidas, não conscientizadas que o poeta vivificará na sua imagem. Percebe-se agora com clareza o ofício e a sensibilidade do poeta: captar esse universo de sensações “pré-s-sentidas”, intuídas, indefinidas que recheiam a infinitude do universo interior de cada indivíduo, dando forma a ele. A poesia encontra nessa fronteira entre percepções claras e impressões indefinidas de algo sua matéria poética por excelência. Na meditação sobre o cinema de Tarkovski, encontra-se uma idéia muito similar. Diz ele:

Impressões isoladas do dia geraram em nós impulsos interiores, evocaram associações; objetos e circunstâncias permaneceram em nossa memória, sem, no entanto, apresentarem contornos claramente definidos, mostrando-se incompletos, aparentemente fortuitos. [...] Será possível transmitir, através de um filme, essas impressões da vida? É evidente que sim; na verdade, a virtude específica do cinema, na condição de mais realista das artes, é ser o veículo de tal comunicação ${ }^{426}$.

Desnecessário dizer que tal afirmação também vale para o teatro. O teatro, a partir do corpo vivo do ator, é tão apto quanto o cinema para tocar nessas zonas fronteiriças, indefinidas, escorregadias que povoam o cotidiano das pessoas. O teatro também é um veículo para “tal comunicação”.

\footnotetext{
425 Tarkovski, op. cit., p.22.

${ }^{426}$ Tarkovski, op. cit., p.21-22.
} 
Voltando ao raciocínio de Paz, ele conclui: “o poema nos faz recordar o que esquecemos: o que somos realmente”427. Nesse sentido, “por obra da imagem produz-se a instantânea reconciliação entre o nome e o objeto, entre a representação e a realidade”. Mas esta é apenas o primeiro ato da operação poética. Paz continua seu raciocínio do seguinte modo:

Quando tropeçamos com uma sentença obscura, dizemos: "O que estas palavras querem dizer é isto ou aquilo". E para dizer "isto ou aquilo" recorremos a outras palavras. Toda frase quer dizer algo que pode ser dito ou explicado por outra frase. Em conseqüência, o sentido ou significado é um querer dizer. Ou seja: um dizer que pode dizer-se de outra maneira. O sentido da imagem, pelo contrário, é a própria imagem: não se pode dizer com outras palavras. A imagem explica-se a si mesma. Nada, exceto ela, pode dizer o que quer dizer. Sentido e imagem são a mesma coisa. Um poema não tem mais sentido que as suas imagens. Ao ver a cadeira, apreendemos instantaneamente seu sentido: sem necessidade de recorrer à palavra, sentamos-nos ${ }^{428}$.

O mesmo ocorreria com o poema. “O poeta não quer dizer, diz”. Segundo paz, “há muitas maneiras de dizer a mesma coisa em prosa; só existe uma em poesia. (...) O dizer poético diz o indizível”.

Mas ainda não se chegou à formulação capital da imagem poética na concepção de Paz. Ele identifica a ambivalência do poema em sua própria natureza dual, que consistiria num movimento duplo da operação poética: "transmutação do tempo histórico em arquetípico e encarnação desse arquétipo em um agora determinado e histórico”. Ou seja, “o poeta não escapa à história, inclusive quando a nega ou ignora. Suas experiências mais secretas ou pessoais se transformam em palavras sociais, históricas. Ao mesmo tempo, e com essas mesmas palavras, o poeta diz outra coisa: revela o homem” ${ }^{429}$. Nesse sentido, pode-se concluir que poesia é, antes de mais nada, palavra carregada de sentido. Para o homem. A agudeza da reflexão de Paz o leva afirmar: “a condição dual da palavra poética não é diversa da natureza do homem, ser temporal e relativo mas sempre lançado ao absoluto”. E para concluir,

A experiência poética não é outra coisa que a revelação da condição humana, isto é, desse transcender-se sem cessar no qual reside precisamente a sua liberdade essencial. Se a liberdade é movimento do

\footnotetext{
${ }^{427}$ Paz, O., op. cit., p.47.

${ }^{428}$ Paz, O., op. cit., p.47.

${ }^{429}$ Paz, O., op. cit., p.55.
} 
ser, transcender-se contínuo do homem, esse movimento deverá estar referido a algo. E assim é: um apontar para um valor ou uma experiência determinada. [...] aquilo de que o poeta fala efetivamente [...] pode ser pessoal, social ou ambas as coisas ao mesmo tempo. Mas ao falar-nos de todos esses sucessos, sentimentos, esperiências e pessoas, o poeta nos fala de outra coisa: do que está fazendo, do que está sendo diante de nós e em nós. E mais ainda: leva-nos a repetir, a recriar seu poema, a nomear aquilo que nomeia; e ao fazê-lo, revela-nos o que somos ${ }^{430}$.

Com esta última citação, fecha-se aqui a tentativa de compreensão da natureza da imagem poética como explanada por Paz. No princípio e no fim, encontra-se o homem no centro, encasquetado com seu próprio enigma. Como a poesia e o ato poético só faz sentido se conectado organicamente com tudo o que diz respeito ao humano, procede a proposição de Bachelard, segundo a qual, “a poesia tem uma felicidade que lhe é própria, independentemente do drama que ela seja levada a ilustrar”431, exatamente como a necessidade da presença de alegria no trabalho do ator, mesmo numa cena em que esteja representando a sua morte.

\section{Imagem verbal}

As imagens verbais podem ser tratadas sob dois pontos de vistas, segundo Santaella: 1. Como linguagem figurada, metafórica; ou, 2. no sentido empregado no Tratactus (1971) por Wittgenstein, ao definir a proposição como um "retrato", "figuração" (picture) da realidade, um “modelo da realidade” que tem em comum com essa realidade (o afigurado) “a forma lógica da afiguração”. Ainda segundo a autora, foi exatamente no campo da Literatura "que o conceito de imagem verbal disseminou-se”, “...substituindo pouco a pouco as figuras de linguagem" ${ }^{432}$.

No Romantismo, todas as variações de imagem, tanto pictóricas quanto verbais e mentais, foram sublimadas nas brumas mais misteriosas e refinadas da imaginação, até que, no Modernismo, a sublimação progressiva da imagem alcançou sua culminação lógica quando o poema inteiro ou texto passou a ser considerado como uma imagem ou "ícone verbal”. Esta imagem não mais concebida como impressão ou

\footnotetext{
${ }^{430}$ Paz, O., op. cit., p.57.

${ }^{431}$ Bachelard, G., op. cit., p.14.

${ }^{432}$ Santaella; Nöth. A imagem, op. cit., p.66.
} 
semelhança pictórica, mas como estrutura sincrônica num espaço metafórico, apresenta, segundo Pound, um complexo intelectual e emocional num instante de tempo ${ }^{433}$.

Em contraposição, porém, “ao caráter metafórico” da imagem no "reino da poesia”, Santaella aponta "um sentido" ainda mais literal nesse campo: o "da qualidade imagética da palavra escrita”, que de qualquer maneira reporta outra vez ao universo da poesia ${ }^{434}$. Ainda com relação à consideração dessa “qualidade imagética da palavra”, Alfredo Bosi faz o seu alerta de que "não é lícito, epistemologicamente, saltar da imagem (...) ao texto sem atravessar o curso das palavras, o seu discurso”435. Octavio Paz, por sua vez, declara a seguinte idéia:

Épica, dramática ou lírica, condensada em uma frase ou desenvolvida em mil páginas, toda imagem aproxima ou conjuga realidades opostas, indiferentes ou distanciadas entre si.

[...] A imagem reproduz o momento de percepção e força o leitor a suscitar dentro de si o objeto um dia percebido ${ }^{436}$.

Portanto, a linguagem verbal é matéria prima no processo de elaboração de uma imagem poética no âmbito da Literatura. Sobre essa elaboração verbal, reflexões consistentes têm sido feitas como demonstram os trabalhos de Alfredo Bosi e Octávio Paz, ainda que os dois partam de pontos de vista inconciliáveis ${ }^{437}$. Antes de desenvolver esse tema, porém, convém salientar de que modo a idéia de imagem é apreendida por eles. Em Octávio Paz, por exemplo, encontra-se uma primeira distição:

A palavra imagem possui, como todos os vocábulos, diversas significações. Por exemplo: vulto, representação, como quando falamos de uma imagem ou escultura de Apolo ou da Virgem. [...] Ou figura real ou irreal que evocamos e produzimos com a imaginação. Neste sentido, o vocábulo possui um valor psicológico: as imagens são produtos imaginários. Não são estes seus únicos significados, nem os que aqui nos interessam. Convém advertir, pois, que designamos com a palavra

\footnotetext{
433 Santaella; Nöth. A imagem, op. cit., p.67.

434 Santaella; Nöth. A imagem, op. cit., p.69.

${ }^{435}$ Bosi, Alfredo. O ser e o tempo da poesia. São Paulo: Cultrix, 1999, p.23.

${ }^{436}$ Paz, Octavio. Signos em rotação, op. cit., p.38-46.

${ }^{437}$ Umas das principais distinções entre os dois intelectuais referem-se ao modo de considerar a linguagem: Paz crê que os objetos estão mais adiante das palavras; enquanto Bosi vê o sistema lingüístico como um modelo da realidade, conforme o concebe Wittegenstei no seu Tractadus...; isso traz implicaçoes para o modo de considerar a criação poética: para Bosi, o poema revela a verdade; para Paz, o poema jamais poderia revelar a verdade, mas o que poderia ser.
} 
imagem toda forma verbal, frase ou conjunto de frases, que o poeta diz e que unidas compõem o poema"438.

Alfredo Bosi recua um pouco mais para ver a imagem encarnada primeiro no corpo do ser humano, como ilustra sua citação a seguir: “A experiência da imagem, anterior à da palavra, vem enraizar-se no corpo. A imagem é afim à sensação visual. O ser vivo tem, a partir do olho, as formas do sol, do mar, do céu. O perfil, a dimensão, a cor”439. Nesse sentido, “a imagem é um modo da presença que tende a suprir o contato direto e a manter, juntas, a realidade do objeto em si e a sua existência em nós”440.

O ato de ver apanha não só a aparência da coisa, mas alguma relação entre nós e essa aparência: primeiro e fatal intervalo. Pascal: 'Figure porte absence et présence'. [...] Formada, a imagem busca aprisionar a alteridade estranha das coisas e dos homens. O desenho mental já é um modo incipiente de apreender o mundo. [...] A imagem, mental ou inscrita, entretém com o visível uma dupla relação que os verbos aparecer e parecer ilustram cabalmente. [...] O objeto dá-se, aparece, abre-se à visão, entrega-se a nós enquanto aparência: esta é a imago primordial que temos dele. Em seguida, com a reprodução da aparência, esta se parece com o que nos apareceu. Da aparência à parecença: momentos contíguos que a linguagem mantém próximos ${ }^{441}$.

Deste modo absolutamente claro, Bosi dá continuidade ao seu deslindamento da idéia de imagem até detectar o engano a que ela pode induzir o sujeito: “cremos 'fixar' o imaginário de um quadro, de um poema, de um romance [...] como se objeto e imagem fossem entes dotados de propriedades homólogas”,442. Pura veleidade, suave ilusão que essa identificação supõe. “A imagem não decalca o modo de ser do objeto, ainda que de alguma forma o apreenda. Porque o imaginado é, a um só tempo, dado e construído. Dado, enquanto matéria. Mas construído, enquanto forma-para o sujeito"443. E finalmente se pergunta: “o que é uma imagem-no-poema?”. Como Octácio Paz que a identifica em toda forma verbal, Bosi declara: “já não é, evidentemente, um ícone do objeto que se fixou na

\footnotetext{
${ }^{438}$ Paz, Octavio. Signos em rotação, op. cit., p.37.

${ }^{439}$ Bosi, Alfredo. O ser e o tempo da poesia, op.cit., p.13.

${ }^{440}$ Bosi, Alfredo. O ser e o tempo da poesia, op.cit., p.13.

${ }^{441}$ Bosi, Alfredo. O ser e o tempo da poesia, op.cit., p.13-14. (Grifos do autor).

${ }^{442}$ Bosi, Alfredo. O ser e o tempo da poesia, op.cit., p.15.

${ }^{443}$ Bosi, Alfredo. O ser e o tempo da poesia, op.cit., p.15.
} 
retina; nem um fantasma produzido na hora do devaneio: [mas] é uma palavra articulada ${ }^{444}$. (Grifo nosso).

A imagem, tanto como totalidade do poema quanto como resultado do poder de evocação de uma única palavra, é detectada por Eisenstein no contexto de sua análise dos modos como aparece o princípio de montagem nos poemas. Em sua análise, são identificadas imagens construídas por um, dois ou mais versos; por um sintagma nominal ou verbal; e, às vezes, ainda por uma única palavra, deixando entrever a precisão de sua percepção com relação a todas essas possibilidades imagéticas de que fala Santaella.

A título de ilustração, tome-se apenas o exemplo do verso VII do poema Poltava de Puchkin, onde se lê uma partícula da descrição de Pedro, o Grande:

Verso VII: /“Seus movimentos ágeis. Magnífico,”/

Na enumeração das imagens, Einsenstein divide o verso em dois planos:

Plano 6: seus movimentos ágeis; e,

Plano 7: Magnífico.

No plano 6, tem-se então uma imagem, formada por um sintagma; e no, 7, trata-se de uma imagem formada por uma única palavra.

Noutro exemplo, Einsenstein mostra como o poeta constrói a imagem de uma "fuga noturna" por meio de "três representações objetivamente expressadas". Em outra cena do mesmo poema Poltava de Puchkin, lê-se os seguintes versos:

Mas ninguém sabia como ou quando

Ela sumira. Um pescador solitário

Ouviu naquela noite o galope de cavalos,

Vozes de cossacos e o sussurro de uma mulher... ${ }^{445}$

Os três planos dividos por Eisenstein:

\footnotetext{
${ }^{444}$ Bosi, Alfredo. O ser e o tempo da poesia, op.cit., p.21.

445 Alexander Sergeievitch Puchkin, Polnoye Sobraniye Sochinenil, Leningrado, 1936, apud Eisenstein, op. cit., p.37.
} 
1. Galope de cavalos

2. Vozes de cossacos

3. O sussurro de uma mulher ${ }^{446}$

Nesse exemplo, Eisenstein observa que o método da montagem é utilizado “com o objetivo de suscitar a necessária experiência emocional do leitor”, porque “a informação de que Marya desaparecera já fora dada no verso anterior”. Para conseguir dar a sensação de fuga, o poeta usa a montagem: “Com três detalhes selecionados entre todos os elementos da fuga, sua imagem de fuga noturna surge na forma de montagem, comunicando a experiência da ação aos sentidos”447.

Para ilustrar o princípio de montagem utilizado (ainda que inconscientemente) na experiência de criação de outros poetas, rememore-se aqui o relato de Maiakovski sobre como conseguiu encontrar a imagem que sintetizava para ele a idéia de "ternura":

Durante dois dias meditei nas palavras de ternura que um solitário dirige à sua única bem amada. Como vai ele olhar por ela, amá-la? Na terceira noite fui deitar-me com dores de cabeça, sem nada ter descoberto. Por fim achei a definição:

O teu corpo,

Hei de cuidá-lo e amá-lo,

Como um soldado mutilado na guerra,

Inútil, sem ninguém,

Cuida

De sua única perna ${ }^{448}$.

Nesse caso, trata-se de uma imagem metafórica que Maiakovski explorou muito no início de sua carreira de poeta. Eisenstein ao se referir a Maiakovski, diz: "ele corta seu verso exatamente como um experiente montador o faria ao construir uma seqüência típica de 'impacto", 449 . "As imagens no poema não levam a outras coisas, como ocorre com a prosa, mas nos colocam diante de uma realidade concreta” ${ }^{\star 450}$.

Eisenstein não se restringiu aos poemas para demonstrar a criação de imagens por meio dos versos. No contexto de seu esforço por ilustrar a aplicação do princípio de montagem em várias modalidades de arte, ele reconhece tratar-se de um princípio já

\footnotetext{
${ }^{446}$ Eisenstein, op. cit., p.37.

${ }^{447}$ Eisenstein, op. cit., p.37.

${ }^{448}$ Maiakovski, Vladimir. Poética. $4^{\mathrm{a}}$ ed. São Paulo: Global, 1984, p.30.

${ }^{449}$ Eisenstein, op. cit., p.47.

${ }^{450}$ Paz, Octavio. Signos em rotação, op. cit., p.47.
} 
utilizado há muito tempo. Para seguir sua demonstração, o cineasta recorre a outros gêneros literários como o romance ou a prosa poética, recorre às artes plásticas, referindo-se às pinturas de Bosh, Da Vinci e outros pintores.

Mas a substância, se se pode dizer assim, aquilo que distingue o modo de construção da imagem verbal, encontra-se com agudeza na formulação de Alfredo Bosi, segundo suas palavras, “a matéria verbal se enlaça com a matéria significada por meio de uma série de articulações fônicas que compõem um código novo, a linguagem”451.

A seqüência fônica articulada não tem a natureza de um simulacro, mas a de um substituto. (...) Formando-se com o apoio exclusivo da corrente de ar em contato com os órgãos da fala, a linguagem se vale de uma tática toda sua para recortar, transpor e socializar as percepções e os sentimentos que o homem é capaz de experimentar. Dizer como faz o poeta,

Qualquer que seja a chuva desses campos

Devemos esperar pelos estios;

$\mathrm{E}$ ao chegar os serões e os fiéis enganos

Amar os sonhos que restarem frios ${ }^{452}$,

nunca será o mesmo que transmitir a outrem, por meio de ícones aglomerados, a mensagem da situação global vivida e das relações internas pensadas pelo falante ao significar o período dado. $\mathrm{O}$ modo encadeado de dizer a experiência renunciou, por certo, àquela fixidez, àquela simultaneidade, àquela forma-dada imediatamente do modo figural de concebê-la. A frase desdobra-se e rejunta-se, cadeia que é de antes e depois, de ainda e já não mais. Existe no tempo, no tempo subsiste. (...) A oração não se dá toda, de vez: o morfema segue o morfema; o sintagma, o sintagma. E entre a cadeia das frases e a cadeia dos eventos, vai-se urdindo a teia dos significados, a realidade paciente do conceito. Mediação e temporalidade supõem-se e necessitam-se ${ }^{453}$.

Nessa formulação de Bosi, fica explícita a diferença profunda entre a imagem verbal e a imagem visual. A imagem visual "impõe-se, arrebata”. Comparado com ela, “o discurso é frágil”, “pede a quem o profere, e a quem o escuta, alguma paciência”. Já o ícone seduz com a sua pura presença, dá-se sem tardança à fruição do olho ${ }^{454}$.

\footnotetext{
${ }^{451}$ Bosi, Alfredo. O ser e o tempo da poesia, op.cit., p.21.

452 Jorge de Lima. Invenção de Orfeu, XXVI apud Bosi, op. cit., p.22.

453 Bosi, op. cit., p.21-22.

${ }^{454}$ Bosi, op. cit., p.25.
} 
Tanto o cinema quanto o teatro, guardadas aí a distância que os separa, realizam-se por meio da combinação de imagens verbais e visuais, denotando aí um grau de complexidade ainda maior, em vista do imenso número de códigos que podem funcionar em suas representações. Elas também podem ser lidas a partir dos eixos paradigmático e sintagmático. Como a linguagem, eles se realiza a partir de mediação e temporalidade, num encadeamento específico de imagens e discursos. Mas trata-se-á do funcionamento da imagem teatral mais abaixo.

\section{Imagem visual}

Quando se fala em imagem visual, pensa-se imeditamente em qualquer objeto ou superfície do mundo. De tão obvia, acaba por se tornar difícil a sua apreensão. A primeira coisa que vem à mente é a pintura, embora se saiba que qualquer sinal ou signo não-verbal possa ser designado como imagem, como por exemplo a fotografia, o cinema, o diagrama, o desenho, as peças publicitárias, os cartazes etc. É justamente para dar conta dessa multiplicidade de signos e sinais característicos do modo de vida contemporâneo que surge, na segunda metade do século XX, a Semiótica como uma nova disciplina do conhecimento. Dentre as várias classificações e sub-classificações das imagens visuais indicadas por Santaella como instrumento para abarcar essa multiplicidade dos signos não verbais, há uma, cuja distinção refere-se ao fato de levar em conta "a relação da imagem com o referente”. Nessa modalidade, há três tipos de imagens:

1. as não-representativas;

2. as figurativas; e,

3. as simbólicas.

Como o próprio nome diz, as imagens não-representativas são chamadas “abstratas”, reduzidas a "elementos puros: tons, cores, manchas, brilhos, contornos, movimentos, ritmos, etc”; as figurativas são “aquelas que transpõem para o plano bidimensional ou criam no espaço tridimensional réplicas de objetos preexistentes”, ou 
visíveis no mundo exterior; as simbólicas são "imagens que, mesmo sendo figurativas, representam algo de caráter abstrato e geral”455.

Como foi referido na introdução deste trabalho, além da tentativa de perseguir a apreensão do que seria a poesia no Nuevo Teatro, ou onde estaria o elemento poético presente na cena, afirmou-se também a pretensão de demonstrar a partir de exemplos outros, tirados da pintura e do cinema, cenas ou quadros que fossem considerados por alguma razão poéticos. Com relação às artes visuais, a referência aqui se direciona para as obras do pintor surrealista, Renné Magritte.

Renné Magritte é considerado um dos pintores mais racionais e ao mesmo tempo mais transgressores da “ordem” do mundo. Ades Dawn comenta que as telas de Salvador Dali eram pertubardoras, "mas não tão verdadeiramente transgressoras quanto as de Magritte”. Estas, “[...] são controvertidas; questionam os nossos pressupostos acerca do mundo, acerca das relações entre um objeto pintado e um objeto real, e estabelecem analogias imprevistas ou justapõem coisas completamente desconexas num estilo deliberadamente inexpressivo", o que teria um efeito de “um lento estopim”. Corroborando esta linha de apreciação da obra de Magritte, Marcel Paquet escreve em seu livro dedicado ao pintor que: “A sua intenção era apenas minar o alicerce das coisas, questionar muito seriamente o que é sério por si, tão simplesmente quanto possível, sem grande confusão, de forma inofensiva e quase anônima ${ }^{456 ”}$. A pintura de Magritte "é sempre a imagem de um pensamento e, como tal, o pintor exige que reflita a sua condição inerente, como imagem. Nunca é uma simples reprodução das aparências, no sentido de ilusão visual, destinada a representar a realidade ${ }^{457}$ nem procura levar o espectador a um mundo distante, antes “espalha luz sobre a incoerência que é comum às nossas formas de pensamento, sejam elas imaginárias ou inconscientes [...]”,458.

Na produção de Magritte, “a imagem pintada não é uma mera reprodução, visto que também retrata a pessoa do pintor, o seu corpo, obtido pela sua forma de ver e a técnica de pintar coisas, o seu olhar e a sua mão”. Nesse sentido, “a pintura não oferece um meio de identificação, como uma fotografia de passaporte; a sua intenção é chamar a atenção, não

\footnotetext{
${ }^{455}$ Santaella; Nöth. A imagem, op. cit., p.82.

${ }^{456}$ Paquet, Marcel. Magritte. Colônia, Taschen, 2000, p.71.

${ }^{457}$ Paquet, Marcel. Magritte, op. cit., p.67.

${ }^{458}$ Paquet, Marcel. Magritte, op. cit., p.75.
} 
para a realidade exterior como tal, mas para o insondável mistério por trás desta realidade”, o que pode ser verificado num de seus mais famoso quadros, o d'A Condição Humana I, por exemplo:

Nele, vê-se um cavalete colocado diante da janela, sustentando o que parece ser uma lâmina de vidro, pois nela está uma continuação exata da paisagem vista através da janela. Entretanto, o "vidro" sobressai ao lado da cortina e mostra ser sólido, de fato, uma pintura numa tela. Assim, trata-se de um quadro dentro de um quadro e embora o ilusionismo seja realmente muito tosco, estabelece-se uma violenta tensão entre o nosso conhecimento da fidelidade da paisagem na tela e a paisagem real, por um lado, e o conhecimento de que ambas são meramente pintadas, por outro ${ }^{459}$.

Ou o quadro O Império da Luzes, onde se encontra a seguinte cena: a imagem central da pintura revela uma casa, ou melhor, uma grande mansão de amplas janelas. No nível da casa, a paisagem é noturna. As árvores, enegrecidas pela noite, são manchas sinistras e o único ponto de luz é uma iluminária na frente da porta de entrada, cujos reflexos morrem na água de uma fonte de jardim defronte à casa. Pode-se ver ainda sob uma grande árvore, do lado esquerdo da tela, restos de luz que vêm de duas janelas. No mais, tudo é breu. Mas algo causa profunda estranheza ao se olhar o céu de um azul muito claro e nuvens brancas. Na altura do céu, é ainda dia. Para Magritte, a poesia se encontra justamente nesse poder de surpreender e encantar que a simutaneidade das imagens carrega. Observe-se nesse caso que não é difícil detectar aí o princípio de montagem como operação da criação do quadro.

"Magritte, com Vincy e Duchamp, crê que todas as imagens têm um sentido, um

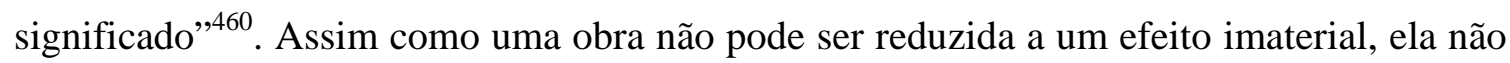
pode ser reduzida também a uma questão de técnicas. A obra é uma amálgama destes dois aspectos. "O significado da obra, o seu efeito estético, leva consigo o traço do "como se”; ou seja, o seu significado emerge através do seu efeito sobre o corpo e o intelecto do observador" ${ }^{461}$.

Para Magritte, a arte de pintar integra o invisível por meio do visível, pensamentos por meio de imagens. O que parece remeter às palavras de Pierre Francastel:

\footnotetext{
459 Paquet, Marcel. Magritte, op. cit., p.75.

${ }^{460}$ Paquet, Marcel. Magritte, op. cit., p.77.

${ }^{461}$ Idem, ibidem.
} 
Pensar ou figurar não é transcrever ou exprimir. É sempre integrar dentro de um sistema, ao mesmo tempo material e imaterial, elementos cuja justaposição cria novos objetos suscetíveis de reconhecimento, de conexão e de interpretação. [...] A obra de arte, especialmente a imagem, não é o reflexo de um real recortado antes de qualquer intervenção do espírito humano em objetos conformes à nossas nomenclaturas. [...] A obra de arte não constitui um sinal de uma realidade localizável por outras vias e exprimível por outras técnicas. Ela não remete a um universo de formas imutavelmente talhadas, ela inicia um processus de representação dialética entre o percebido, o real e o imaginário; ela não é analógica mas sempre constelada por numerosos elementos que associam lugares e tempos não-homogêneos. Ela não remete a um absoluto mas aos devires humanos ${ }^{462}$.

Magritte acabou sendo “classificado” como surrealista, mesmo que ele nunca tenha se afirmado como tal. O Surrealismo, “último instantâneo da inteligência européia”, foi um dos movimentos de vanguarda histórica que "brotou na França, em 1919, entre alguns intelectuais (citemos de imediato os mais importantes: André Breton, Louis Arago, Phillippe Soupault, Robert Desnos, Paul Éluard)...”463 . “[...] Nasceu de um desejo de ação positiva, de começar a reconstruir a partir das ruínas de Dadá” ${ }^{464}$. A referência que se faz aqui da imagem poética surrealista se justifica por elos de fundo comum: um dos dados curiosos deste movimento é a influência recebida pelo pensamento de Freud, que influenciou também a estética naturalista russa bem como o método da improvisação teatral de Enrique Buenaventura no TEC, como se poderá atestar no capítulo 2.

Ades Dawn chama a atenção para a "imagem surrealista” tal como aparece na “colcha de retalhos” do primeiro Manifesto. A definição de surrealismo enfatiza o automatismo, "mas uma extensa parte é dedicada aos sonhos, que Freud tinha revelado serem uma expressão direta da mente inconsciente, quando a mente consciente diminuía seu controle durante o sono" ${ }^{465}$ :

A imagem surrealista nasce da justaposição fortuita de duas realidades diferentes, e é da centelha gerada por esse encontro que depende a beleza da imagem; quanto mais diferentes forem os dois termos da imagem,

\footnotetext{
${ }^{462}$ Francastel, Pierre. A realidade figurativa. São Paulo, Perspectiva,

463 Benjamim, Walter. “O surrealismo”. In Magia e técnica, arte e política. São Paulo, Brasiliense, 1994, p.21.

464 Ades, Dawn. “Dada e Surrealismo”. In: Stangos, Nikos (ed.). Conceitos da arte moderna. Rio de Janeiro, Zahar, 2000, p.89.

465 Ades, Dawn. “Dada e Surrealismo”, op. cit., p.92.
} 
mais brilhante será a centelha”. [...] Muitas telas surrealistas têm características do que Freud chamou "labor do sonho", como, por exemplo, a existência de elementos contrários lado a lado, a condensação de dois ou mais objetos ou imagens, o uso de objetos que têm um valor simbólico $[\ldots]^{, 466}$.

No âmbito das artes visuais, os principais criadores no movimento surrealista foram pintores tais como Picasso, Braque, De Chirico, Max Ernest, Man Ray, Masson, Salvador Dali, Arp, Miró, Tanguy e Magritte.

Depois do colocado até aqui, poder-se-á discutir um dos focos centrais desta introdução, a da imagem teatral.

\section{Imagem teatral}

“O espetáculo serve-se tanto da palavra como de sistemas de significação nãolingüística. Utiliza-se tanto de signos auditivos como visuais”467. A complexidade da arte teatral envolve esse duplo aspecto imagético, tanto a imagem suscitada por meio da palavra articulada quanto aquela sugerida pela composição da corporalidade do ator, dos objetos e dos adereços de cena. O teatro produz imagens o tempo todo. Ou melhor, todas as modalidades artísticas produzem imagens. Nada mais elementar em se tratando do mundo humano, uma vez que “o homem vive imagens” como quer a fenomelogia de Gaston Bachelard ${ }^{468}$.

Todo teatro produz imagens. Esteja a serviço do texto, ilustrando-o ou não, a cena projeta imagens tridimensionais, que se transformam continuamente por meio do movimento. Tanto no cinema quanto no teatro, estas imagens podem representar a vida humana de forma figurativa ou metafórica. Embora sejam abissais as distinções entre cinema e teatro, ambas são artes que se realizam no espaço e no tempo. Mas o teatro é menos capaz do que o cinema de representar com realismo a totalidade da vida. Foi em razão mesma dessa incapacidade ao se comparar com o cinema que o teatro foi forçado, tal como as artes plásticas com relação à fotografia, a refletir sobre sua própria especificidade

\footnotetext{
466 Ades, Dawn. “Dada e Surrealismo”, op. cit., p.92-96.

${ }^{467}$ Kowsan, Tadeusz. “Os signos no Teatro - introdução à semiologia da arte do espetáculo” In: Guinsburg, J.; Teixeira Coelho Netto, J. ; Cardos, Reni Chaves. Semiologia do teatro. São Paulo, Perspectiva, 1988.

${ }^{468}$ Bachelard, Gaston. A poética do espaço, p.121.
} 
no curso do século XX. O movimento das imagens no teatro é produzido pela presença e pela corporalidade do ator sem mediações tecnológicas. No cinema, ainda que sua força de representação no que concerne à reprodução fidedigna da realidade seja irrefutável, o que se tem é uma ilusão do movimento sem a presença viva do ator. A reprodução do movimento é resultado de um mecanismo alta e tecnicamente elaborado: a associação de determinada velocidade dos fotogramas ao que Eisenstein chamou de "persistência de visão”: “...a persistência de visão de um fotograma sobre o fotograma seguinte da tira do filme é que cria a ilusão do movimento cinematográfico”469. Além disso, “ao contrário do cinema e da pintura”, a imagem cênica “não necessita de um 'suporte material' como a tela ou a película; mas se assim [se pode] dizer, o suporte material é o próprio objeto, o próprio espaço" $^{\text {,470. }}$.

Apesar destas diferenças, houve uma forte influência do teatro sobre a película nos primórdios do cinema. Fase que ficou conhecida como sendo a da produção de "teatro filmado"471. Ao descobrirem o grande poder de atração que a tela exercia sobre as classes populares - que não dispunham de condições para custear uma ida ao teatro, reservado aos mais abastardos -, os produtores começaram a filmar obras teatrais, às vezes, utilizavam a própria montagem em cartaz no teatro, obtendo grande êxito com custos relativamente baixos. Mas, ao mesmo tempo, pode-se falar também da influência do cinema sobre a cena teatral. Ao consquistar seu próprio rigor e método, depois de explorações amplas de suas possibilidades estéticas por meio das tentativas de um Eisenstein, um Vertov ou um

\footnotetext{
${ }^{469}$ Eisenstein. O sentido do Filme. p.57.

${ }^{470}$ Ubersfeld, Anne. Para ler o teatro. São Paulo, Perspectiva, 2005, p.98, (grifos da autora).

${ }^{471}$ Com relação a este teatro filmado dos anos 20-30 do século XX, uma pequena digressão. As possibilidades de bons negócios na produção de diversão de baixo custo para as massas logo se confirmaram com o grande êxito desses teatros filmados. Em seguida, produtores norte-americanos e franceses interessados em atrair a classe média européia para dentro da sala de cinemas forjaram a idéia de "cinema de arte" que não passava nessa época, da produção de teatro filmado do repertório clássico da Literatura dramática universal ${ }^{471}$. Nesse contexto, ocorre, por exemplo, a disputa entre Bertolt Brecht e os produtores cinematográficos em torno dos direitos de filmagem da peça de Brecht, “Ópera dos Três Vinténs”, em razão da quebra de contrato praticada pela produtora que não tinha interesse algum em explorar a linguagem do cinema, mas simplesmente produzir mais um teatro filmado de suposto sucesso na tela, como já o era no palco; gerando assim um conflito direto com BB, que tinha liberado os direitos autorais sob condições bem específicas, voltadas justamente para sua participação na adaptação do roteiro, tendo em vista se tratar de arte nova, que exigia pesquisa estética também específica. Essa disputa deixa clara a atração que o cinema exercia sobre Bertolt Brecht ${ }^{471}$ tanto no sentido de que poderia ampiliar os horizontes da cena teatral quanto no da especulação sobre as ilimitadas possibilidades da própria linguagem cinematográfica.
} 
Griffith, detecta-se um movimento contrário: o da influência do cinema sobre o teatro, como a citação de Patrice Pavis confirma:

A estética teatral de Meyerhold foi influenciada pelo cinema russo e soviético, sobretudo por aquele de seu antigo ator Eisenstein, mas seus empréstimos à estética do filme nunca foram diretos. Como escreve muito bem Uwe Richterich: "Meyerhold não estava interessado na simples utilização do cinema como alargamento técnico das possibilidades do teatro, mas na incorporação das implicações estéticas do olhar fílmico". Se não encontramos no teatro de Meyerhold tela e projeções em cena, por outro lado a encenação e a representação do ator utilizam técnicas de montagem cinematográficas, sobretudo a "montagem das atrações" "472.

Na tradução feita por Arlete Cavaliere de parte dos vários escritos de Meyerhold, encontra-se o artigo "De uma conversa com os atores”, de 15 de março de 1926, onde se lê comentários do próprio encenador sobre a repercussão de uma de suas obras primas, $O$ Inspetor Geral. Neste texto, há referências sobre este aspecto cinematográfico de suas peças. A título de curiosidade, vale lembrar que esta encenação embora tenha provocado a indignação da crítica especializada ("profanação” da obra de GÓgol), foi muito apreciada pelo espectador comum conforme indicação do próprio Meyerhold, como pode se conferir na citação abaixo:

O que me anima em nosso Inspetor é que nele existe esta verdade que tem legitimidade nas massas. E quase todos os críticos moscovitas, como que concordes, começaram a gritar que nosso Inspetor é uma verdadeira profanação, que O inspetor é um Gógol deformado, que o Inspetor de Meyehold só o diabo sabe o que é, que por causa deste Inspetor é preciso exilar Meyerhold da Rússia, que é preciso mandá-lo para o inferno, onde quer que esteja! Escreveram as coisas mais inverossímeis. Enquanto isso, dia após dias, nosso teatro que comporta, se não me engano, 1200 pessoas continua lotado, lota dia após dia, apesar das opiniões pessoais dos críticos que as expressam sem qualquer argumentação. Mas os soldados do Exército Vermelho interrogados pelo komsomólskaia Pravda e os espectadores tirados da massa, em oposição aos críticos, afirmam que é um espetáculo muito alegre, muito dinâmico, muito cinematográfico. Isso me deixa muito contente ${ }^{473}$. (Grifo nosso).

\footnotetext{
${ }^{472}$ Pavis, Patrice. Análise dos espetáculos, p.43. A citação que Pavis faz no interior deste trecho refere-se à obra de Uwe Reichterich, Die Sehnsucht zu sehen. Der filmische Blick, Frankfurt, Peter Lang, 1993, p.43.

${ }^{473}$ Cavaliere, Arlete. O Inspetor Geral de Gogol/Meyerhold: um espetáculo síntese. São Paulo, Perspectiva, 1996, p.77.
} 
Ainda sobre a relação entre teatro e cinema, podem ser valiosos os comentários de Béatrice Picon-Vallin em sua obra dedicada a Meyerhold, segundo a qual, “o cinema [...] funciona como um reservatório de imagens para os criadores de teatro que completam assim as fontes visuais pictóricas (quadros, desenhos), e sobretudo fotográficas (cartões postais, fotos, negativos), as fotos difundindo também a pintura (livros de arte, reproduções)”,474. Além disso,

[...] teatro e cinema, nos grandes países europeus na área teatral - Rússia, Alemanha - andaram de par: o cinema e suas técnicas se desenvolvem nos palcos no momento em que a indústria cinematográfica está em franca desorganização. É, aliás, aí que André Malraux situa a diferença fundamental entre a encenação russo-alemã, antes de tudo plástica, e o teatro francês, de Vilar, para quem "pôr em cena” era antes de mais nada "pôr no ponto certo". Vilar, respondendo a Malraux que lhe descreve o funcionamento de um espetáculo de Meyerhold: "Eu falo de teatro e o senhor me responde com cinema" ${ }^{\text {,75 }}$.

Segundo Picon-Vallin, “já em 1910 Meyerhold tinha apontado isto: o espectador exige 'que Maeterlinck lhe seja apresentado com os aperfeiçoamentos adquiridos pelo cinema”, ${ }^{476}$. Deste modo, corrobora-se aqui, por meio destas citações, a ocorrência do intercâmbio entre esses dois campos artísticos nos primórdios do desenvolvimento do cinema na Rússia e Alemanha. “A integração do cinema ao ato teatral se fez pelo modo [...] [como] suas técnicas e imagens alimentaram e ainda alimentam a arte da encenação”. Refere-se aqui à apropriação pela encenação dos princípios “de montagem, de enquadramento e, mais recentemente, pela noção de movimentos de aparelhos”477.

Para além de todas as trocas mútuas entre teatro e cinema, evocar Meyerhold no contexto de uma tentativa de apuração da natureza da imagem teatral se deve ao fato de ele ser considerado por muitos estudiosos ${ }^{478}$ um dos grandes revolucionários da cena teatral do século XX bem como o pioneiro no que diz respeito à reflexão da cena como imagem, ou seja, como “configuração composicional e imagética”. Sobre este último dado, Picon-

\footnotetext{
${ }^{474}$ Picon-Vallin, B. A arte do teatro: entre tradição e vanguarda. Meyerhold e a cena contemporânea. Rio de Janeiro: Folhetim, Teatro do pequeno gesto, 2006, p.98.

${ }_{475}$ Picon-Vallin, B, A arte do teatro..., op. cit., p.98.

${ }^{476}$ Picon-Vallin, B, A arte do teatro..., op. cit., idem.

${ }^{477}$ Picon-Vallin, B, A arte do teatro..., op. cit., idem.

${ }^{478}$ A descoberta paulatina da importância da contribuição de Meyerhold para a cena contemporânea só começou na segunda metade do século XX. É sabido de todos os longos anos de silêncio após a execução do encenador imposta pela ditadura de Stalin, desde 1940.
} 
Vallin faz referência a um texto de um crítico russo, que vale a pena reproduzir aqui. Tratase de um artigo de Nicolai Tarabukin, historiador da arte, autor de várias obras sobre as vanguardas plásticas e de análises “pertinentes” sobre a composição visual dos espetáculos meyerholdianos. Nesse artigo, o crítico está apresentando ao público estrangeiro a originalidade e a essência das criações de Meyerhold ${ }^{479}$ :

Uma peça, dita por atores mesmo maquiados e com figurinos sobre um palco, não se torna necessariamente um espetáculo. Essas pretensas "encenações" devem ser relacionadas à arte da declamação, não à do espetáculo. Um espetáculo é, antes de tudo, algo para ser olhado. E o teatro é, antes de mais nada, uma arte figurativa. A própria palavra espetáculo vem do latim spectare, que significa olhar. E, embora o vocabulário teatral possua um certo número de termos que caracterizam a especificidade da arte cênica, é raro que a idéia que o sustenta encontre uma encarnação concreta. A começar pela expressão pôr em cena. Monta-se uma peça. O cartaz exibe o nome do autor da encenação. Entretanto, na maior parte das vezes, sobre o palco, nós ouvimos uma peça, mas a encenação dela, quer dizer, sua configuração composicional e imagética, nós não vemos ${ }^{400}$.

Afinado com as teorizações de Gordon Craig sobre as "visões cênicas, e sobre o teatro como uma obra de arte que se dirige antes de tudo ao ver, Meyerhold, em 1930, “encarna no mais alto grau, segundo Louis Jouvet, ‘a idéia que é lícito formar a respeito do encenador' ${ }^{481}$. Ele era o 'criador de formas, um poeta da cena [que] escreve com gestos, ritmos, com toda uma língua teatral [...] que fala aos olhos na mesma medida em que o texto se dirige aos ouvidos’ [...]”482. E não se tratava de imagem ilustrativa do texto. Meyerhold não se cansava de afirmar que "para se tornar um encenador, é necessário deixar de ser um ilustrador".

A partir destas referências, esquematicamente evocadas, propõe-se chamar a atenção para a figura de Meyerhold na origem de parte das inovações revolucionárias da cena contemporânea. É só recentemente que tem aparecido publicações sobre suas teorizações, após o longo silêncio do qual foi vítima. É só recentemente que tem surgido o

\footnotetext{
${ }^{479}$ Picon-Vallin, B, A arte do teatro..., op. cit., p.84.

${ }_{481}^{480}$ Picon-Vallin, B, A arte do teatro..., op. cit., p.84.

${ }^{482}$ Dullin, Charles. "Recontres avec Meyerhold, in Souvenir set notes de travail d'um acteur. Paris: Lieutier, 1946, p.45 apud Picon-Vallin, B. A arte do teatro..., op. cit., p.88-89.
} 
impulso para o reconhecimento do grande valor do seu legado artístico e do seu lugar na história do teatro moderno mundial.

Com relação à imagem cênica, presente de uma ponta à outro no amplo arco de escolas estéticas, estilos, e a gama de criações híbridas e mistas - produzidas mais contemporaneamente com a tendência ao apagamento de fronteiras entres as modalidades artístcas - surgiu uma vertente cuja preocupação central gira em torno exatamente da criação desta imagem cênica e por isso mesmo ficou conhecida como "teatro de imagens". No seu Dicionário de Teatro, Patrice Pavis se refere assim a essa vertente:

A imagem desempenha um papel cada vez maior na prática teatral contemporânea, pois tornou-se a expressão e a noção que se opõe àquelas de texto, fábula, ou ação. Havendo reconquistado completamente sua natureza visual de representação, o teatro de imagens chega mesmo a recorrer a uma seqüência de imagens e a tratar os materiais lingüísticos e actanciais como imagens ou quadros ${ }^{483}$.

De qualquer maneira, “a encenação é sempre colocação em imagens, porém ela é mais ou menos ‘imaginada’ e ‘imaginante’: no lugar de uma figuração mimética ou de uma abstração simbólica, (...) [ter-se-ia] uma cena feita de uma seqüência de imagens de grande beleza”484.

Esta imagem é contruída por meio do espaço que o teatro precisa para existir. “Como o teatro representa atividades humanas, o espaço teatral será o lugar dessas atividades, lugar que terá, obrigatoriamente, uma relação (de fidelidade ou distância) com o espaço referencial dos seres huamanos" ${ }^{\text {485 }}$. Ou seja, o espaço teatral é a imagem e a contraprova de um espaço real. Junto com as proposições de Ubersfeld, poder-se-á definir agora o signo espacial do teatro (isto é, a imagem), analisando-o não como signo textual, mas como signo da representação: deste mdo, "o signo cênico (o espaço cênico como conjunto de signos espacializados) é de natureza icônica e não arbitrária”, no que distingue da linguagem verbal. Para elucidar em que consiste a natureza do signo teatral, Ubersfeld faz referência aos pensamentos de Peirce, Charles Morris e Umberto Eco. A precisão de

\footnotetext{
${ }^{483}$ Pavis, P. Dicionário de teatro. São Paulo, Perspectiva, 2005, p.204.

${ }^{484}$ Pavis, P. Dicionário..., op.cit., p.204.

${ }^{485}$ Ubersfeld, A., op. cit., p.91.
} 
Eco, na consideração de Ubersfeld, leva-a a encerrar este ponto referente ao signo com a sua citação. Assim, só se pode atribuir sentido à noção de iconicidade:

a) através do processo da percepção,

b) auxiliado pela noção de código, e conclui:

1)os signos icônicos 'não possuem as propriedades do objeto representado;

2) reproduzem algumas condições da percepção comum, com base nos códigos perceptivos normais'. E acrescenta ainda com mais precisão: 'os signos icônicos reproduzem certas condições da percepção do objeto, somente após tê-las selecionado com base em códigos de reconhecimento e anotado com base em convenções gráficas ${ }^{, 486}$.

Ubersfeld adapta certas definições como esta última acima por não se aplicarem ao signo cênico. No teatro não se trata mais de “conveções gráficas”, mas de outros tipos de convenção. "O objeto teatral é um objeto no mundo, em princípio idêntico (ou funcionalmente semelhante) ao objeto do “real” não teatral, do qual é ícone. Trata-se de um objeto situado em um espaço concreto, que é o espaço da cena”. Além disso, se “[...] todo signo icônico é não arbitrário, mas motivado, o signo cênico é duplamente motivado, se podemos dizer, na medida em que é ao mesmo tempo a mímesis de alguma coisa (o ícone de um elemento espacializado) e um elemento em uma realidade autônoma, concreta”487 (grido da autora).

Como já aludido no início deste tópico,

o texto (diálogo) figura na representação como sistema de signos lingüísticos cuja matéria é fônica. O texto do diálogo é ouvido como fala (com duplo destinário) e ao mesmo tempo como poema (objeto poético). Mas a representação é também a imagem visual plástica e dinâmica das redes textuais, e esse aspecto, embora menos visível, não deixa de ser capital $^{488}$.

O espetáculo teatral como produtor tanto de imagens verbais quanto de imagens visuais quer por meio delas comunicar algo à platéia. Assim, o processo de comunicação que permeia toda a representação teatral torna-a sensível à operação dos conceitos lingüísticos como por exemplo as seis funções da linguagem desenvolvida por Roman

\footnotetext{
${ }^{486}$ Eco, U. La Structure Absente, p.172-174; apud Ubersfeld, A., op. cit., p.98.

${ }^{487}$ Ubersfeld, A., op. cit., p.98.

${ }^{488}$ Ubersfeld, A., op. cit., p.104.
} 
Jakobson $^{489}$. Eles "são pertinentes tanto para os signos do texto, como para os da representação” ${ }^{490}$. Então, estão presentes numa representação teatral as funções emotiva, conativa, referencial, fática, metalingüística e poética. Não parece haver necessidade em se deter em cada uma desta funções, dada a evidência da pertinência de sua aplicação à análise do discurso teatral ou do texto do espetáculo. A alusão a estas funções se deve mais ao interesse na elucidação de uma única função: a poética. Embora o uso desse conceito no contexto do presente trabalho tenha sido assumido em sua acepção qualificativa, é irrefutável a imbricação da "Poética” com o "poético" como se tentou demonstrar no subtópico 2 mais acima. A partir da aplicação dos pressupostos da Lingüística ao Teatro torna mais clara a compreensão da própria "natureza poética” do "funcionamento teatral" como Ubersfeld indica abaixo:

A função poética, que remete à mensagem propriamente dita, pode aclarar as relações entre as redes sêmicas textuais e as da representação. O funcionamento teatral é, mais que qualquer outro, de natureza poética, se o trabalho poético é, como quer Jakobson, projeção do paradigma sobre o sintagma, dos signos textuais-representados sobre a totalidade diacrônica da representação.

Longe de ser apenas um modo de análise do discurso teatral (e particularmente do texto dialogado), o processo de comunicação como um todo pode esclarecer a representação como prática concreta ${ }^{491}$. (Grifo da autora).

Para além da própria natureza poética da representação teatral, a imagem cênica, ou seja, a imagem visual contruída no espaço cênico de uma representação teatral pode ser considerada como sendo poética ou não; pode ser considerada como sendo poética de mais ou de menos. Além disso, esse grau de “poesia” da cena pode ser detectada tanto nessa imagem visual quanto na própria imagem verbal do discurso textual da cena. A imagem poética teatral como diz

\section{A imagem poética do Nuevo Teatro}

\footnotetext{
489 Jakobson, Roman. Ensaios de Lingüística Geral.

${ }^{490}$ Ubersfeld, A., op. cit., p.19.

${ }^{491}$ Ubersfeld, A., op. cit., p.20.
} 
Ousar-se a afirmar que o mesmo princípio poético que orientou a criação de obras como as montagens de Meyerhold, as pinturas de René Magritte (1898-1967) ou os filmes de Tarkovski e Eisenstein, estão presentes nas montagens e na teoria de Enrique Buenaventura e Santiago Garcia. Se se detiver em cenas como algumas presentes em $A$ morte de Tintagales, ou no quadro O Império das Luzes, ou em cenas de Nostalgia, poderse-á ilustrar em que consiste este princípio poético, mais do que se se tentasse explicá-lo verbalmente. É claro que com relação à montagem de Meyerhold só se pode fazer deduções a partir de seus escritos ou dos escritos feitos sobre ele de seus contemporâneos e estudiosos posteriores. A partir dessa literatura, fica-se sabendo dos efeitos cênicos conseguidos por meio de sua experimentação que exploravam a composição da cena, o movimento plástico e musical, os silêncios e pausas, para cujos resultados Meyerhold chamaria de "teatro da convenção". Tratavam-se dos primórdios do que viriam a ser conceituados de grotesco e de estilização. Na montagem de A morte de Tintagales por exemplo em vários momentos, dizem os comentadores, as cenas se configurariam assim e assim. Na pintura O Iimpério das Luzes, de Magritte, defronta-se com “uma cena noturna sob um céu diurno”. O próprio artista, racional, oferece a sua explicação: “a paisagem levanos a pensar na noite, o céu no dia. Na minha opinião, esta simultaneidade de dia e noite tem o poder de surpreender e de encantar. Chamo a este poder poesia”492. No filme Nostalgia de Tarkovski há uma cena em que surge na tela a casa russa dentro de uma catedral italiana. A fusão das duas paisagens numa imagem única também está prenhe deste poder de que fala Magritte, ou seja, deste poder poético que gera no espectador primeiro um encantamento, depois certa reflexão sobre a condição humana no modo de vida moderna e contemporânea que torna o homem estrangeiro dentro de seu próprio lar e ao mesmo tempo um sentir-se em casa em qualquer lugar do mundo. A cena se liga conceitual e racionalmente ao próprio nome do filme Nostalgia. É como se Tarkovski conseguisse traduzir nessa imagem cinematográfica o sentimento indizível do que seria nostalgia (indizibilidade, que na verdade é característica de todo sentimento).

\footnotetext{
${ }^{492}$ Picon-Vallin, B. A arte do teatro: entre tradição e vanguarda. Meyerhold e a cena contemporânea. Rio de Janeiro: Folhetim, Teatro do pequeno gesto, 2006, p.98.
} 


\section{A IMAGEM POÉTICA DO NUEVO TEATRO}

Dufrenne diz que "no estado poético, como em toda percepção, estamos presentes ao real: alguma coisa age sobre nós e alguma coisa nos é comunicada”. E que "nesse ponto de receptividade em que a poesia [não só a verbal, completar-se-ia aqui] nos leva, não é uma emoção que nos é infligida e que nós projetaríamos de volta sobre o objeto”. Ou seja,

certamente somos tocados pelo poema, mas não somos reenviados a nós mesmos. Somos comovidos ao descobrir um mundo, que está longe de ser a expressão da nossa emoção. Também na música, como bem mostrou Susanne Langer, o sentido não se reduz ao afetivo. Uma emoção, pois, não forma um sentido; no máximo, acompanha-o quando esse a suscita ${ }^{493}$.

Na encenação teatral, quando este estado poético é produzido no espectador, ele costuma se dá de forma muito mais complexa em virtude da própria natureza do teatro, que envolve parte dos sentidos humanos em sua percepção. Visão dinâmica: imagens sonoras e visuais, compostas a partir de linhas, cores, volumes, luz, som e movimento, tudo dado à percepção e imaginação do espectador, numa miríade de estímulos que nenhuma modadlidade artística é capaz.

O corpo-a-corpo com a materialidade do espetáculo deve então ser tomado no sentido próprio: o analista (...) efetua uma volta para o corpo da representação para além da sublimação que representa todo o uso de signos; compenetra-se na experiência estética e nas coisas materiais que lhe oferecem a cena ${ }^{494}$.

Como já foi discutido o conceito de imagem e de imagem poética na introdução do presente trabalho, tentar-se-á neste capítulo detectar a presença daqueles elementos na estrutrura da obra de arte teatral a que se pode atribuir a idéia de se tratar de uma imagem poética, em obras teatrais produzidas pelos dois grupos teatrais colombianos em foco, TEC e LA CANDELÁRIA. Mas antes, faz-se necessário um pequeno intróito sobre o material de registro disponibilizado para a pesquisa.

\footnotetext{
${ }^{493}$ Dufrenne, Mikel. O poético. Porto Alegre, Editora Globo, 1969, 106.

${ }^{494}$ Pavis, P. Análise dos espetáculos. São Paulo, Perspectiva, 2003, p.14.
} 
A análise que se segue sobre cenas dos espetáculos dos grupos teatrais referidos acima foi possível em virtude da obtenção de cópias em “dvds” de registros fílmicos feitos destas montagens. São peças teatrais consideradas clássicas do repertório do nuevo teatro latino-americano e colombiano. Quando se fala em "teatro filmado" aqui não se refere mais àquele tratamento pejorativo concernente à produção cinematográfica dos anos 20-30, mas simplesmente a uma forma de documentação. Pressupõe-se, de acordo com as colocações de Patrice Pavis, a restituição do “tempo real” e do “movimento geral do espetáculo” que a linguagem do vídeo propiciou. Com isso, o vídeo passa a constituir “a mídia mais completa para reunir o maior número de informações, particularmente sobre a correspondência entre os sistemas de signos e entre a imagem e o som»495. Entretanto, há que se advertir que a mediação do próprio aparato tecnológico interfere de algum modo na natureza da obra, ainda mais em se tratando de uma obra de arte teatral, cuja natureza está inequivocadamente ligada à sua efemeridade: o espetáculo acontece aqui e agora, num espaço e num tempo determinados, após sua apresentação viva, esvaiu-se, acabou-se, a única coisa que resta são as imagens mentais assimiladas pelo espectador, ou seja, na lembrança de alguém. Nada mais. Obviamente, podo-se ter fotos, artigos e todo tipo de registro sobre o acontecimento; mas o acontecimento em si é irrepetível. Depois sair de cartaz uma peça, não é mais possível ter acesso a tal experiência. A menos que o elenco se reúna e volta a aprensentar a montagem. No âmbito da música, que se dá principalmente numa seqüência temporal, não se pode dizer que, ao ouvir uma cópia em $\mathrm{CD}$, também produto dos avanços tecnológicos, perde-se grande quantidade de informação da obra; mesmo que a magia de assistir a execução de uma peça musical ao vivo por uma orquestra, seja uma experiência estética das mais prazerosas, ao se ouvir num aparelho uma obra, o essencial da obra está presente ali. Isso, como se viu, não acontece com o teatro. Assistir a uma peça de teatro filmada jamais substituirá aquilo que é essencial no teatro: a presença física, viva, corpórea do ator.

No caso da análise das montagens dos dois grupos teatrais colombianos, por exemplo, os tratamentos serão distintos em função das condições e da forma como foram filmadas suas obras. Tome-se inicialmente o contexto da filmagem das duas obras do TEC

\footnotetext{
${ }^{495}$ Pavis, P. Análise..., op. cit., p.37.
} 
analisadas no presente trabalho. Trata-se em primeiro lugar de um documento histórico, ou seja, de um registro valioso para a história do teatro latino-americano: as peças La Orgia e Soldados foram filmadas em 1971, no contexto da primeira participação do TEC no VIII Festival de Teatro de Nancy ${ }^{496}$, na França. Foram gravadas por um concidadão, Pedro Nel Rey, que na ocasião se encontrava na cidade. Conclui-se desse fato duas conseqüências: 1) A seqüência registrada no filme obedece diretamente ao olhar desse concidadão, que necessariamente será distinto do que seria se o diretor do filme fosse o mesmo diretor dos espetáculos. 2) Em razão disso, ter-se-á nestes filmes um registro muito livre, com closes, cortes, planos gerais, médios e fechados; o que desemboca inevitavelmente num tipo de registro a meio caminho daquele editado e montado. Isto quer dizer que a análise parte então de imagens "re-criadas" a partir da imagem teatral original, num distanciamento de segundo grau. O que pressupõe por isto mesmo uma sobreposição de olhares. Afasta-se do espaço total da cena por meio do modo do uso da mediação tecnológica, promovendo tanto um recuo quanto uma aproximação. O recuo no sentido de a obra se oferecer agora interceptado por um segundo olhar, o do diretor do filme; e a aproximação, no sentido de que os recortes e closes permitem a percepção de detalhes da cena que de outro modo seria impossível.

Assim se dá a curiosa situação percebida no filme da peça em que o cineasta parece estar correndo atrás da cena. Ao não conhecer muito bem as "linhas de força”, os "vetores" e os deslocamentos no curso da peça, parece ao espectador do filme que a câmera está correndo atrás do movimento na cena, manifestada em seus deslocamentos no palco e na relação proxêmica entre os atores, quando o foco da cena é levado a localizações no espaço cênico “inesperados” pela câmera, o foco fica fora de enquadramento por segundos. Por outro lado, o cineasta tenta detectar por meio da lente aquela nuance que seria impossível ao espectador de teatro, dada a distância entre palco e platéia. Por mais próximos que estes possam ser, a platéia jamais poderá estar tão próxima do ator quanto o olho de uma câmera que, por meio do zoom, entre outros recursos, é capaz de captar pequenos sinais faciais do ator. Assim, detalhes da atuação do ator que passariam desapercebidos, ao se tornarem

\footnotetext{
${ }^{496}$ Participaram deste Festival mais dois grupos colombianos: La Mama e La Candelária.
} 
acessíveis por meio dos recursos do vídeo, promovem percepções novas que podem auxiliar na análise das obras.

O ideal para o analista da cena teatral seria a combinação de ambas as fontes: o de ter podido assistir a obra teatral junto com a aquisição de seu registro em filme. Isso foi possível apenas com relação às duas montagens selecionadas do grupo La Candelária, até por se tratarem de produções mais recentes, uma do final da década de 80, a outro do início da de 90. Estas duas montagens estavam em cartaz junto com outras obras de repertório do grupo, quando a pesquisadora viajou à Colômbia. Deste modo, além de ter assistido às peças El Paso e En la Raya, foi possível também conseguir cópias dos seus registros áudiovisuais. Vale lembrar, que no caso do La Candelária, o documento filmado das peças, ou seja, o "teatro filmado", tem um enquadramento menos livre e contém menos cortes, privilegiando a câmera fixada num plano geral, de modo a abarcar na maior parte da representação as várias ações simultâneas que acontecem em pontos diferentes do espaço.

As obras do TEC analisadas neste trabalho são mais antigas, não estão mais em repertório, mas a existência deste filme não só recupera cenas que podem ser consideradas antológicas do Nuevo Teatro como também torna possível sua análise do ponto de vista a que se propôs este estudo, qual seja, o de debruçar sobre a representação da obra, de identificar pistas que levam à idéia da presença de imagens poéticas, resultantes de pesquisa artística como princípio de trabalho tão importante quanto aqueles referentes ao seu engajamento sócio-político. Cotejando-se o registro do filme com análises de estudiosos que assistiram ao espetáculo na época pôde-se alcançar um quadro mais completo de sua imagem teatral e poética.

\section{Análise de obras e cenas}

A preocupação com a criação da imagem poética foi uma constante para ambos os encenadores colombianos. Encontra-se no sistema teórico de ambos não só a recorrência do termo bem como métodos de trabalho para alcançá-la. Esta é a finalidade principal do recurso das improvisações e da criação coletiva: atingir certa autenticidade na configuração de uma imagem do homem latino-americano. Uma imagem capaz de povoar o imaginário dessa gente muitas vezes perdidas no tempo e no espaço. Essa necessidade não só 
aproximou o teatro do seu público como também tornou essa relação com esse público em sua razão de viver. Nem sempre uma relação amistosa, às vezes, de franco confronto, mas ambos embuídos da necessidade de resolver o enigma do próprio ser.

Os princípios de “montagem”, “condensação” e “conflito” associados a conceitos semióticos compõem o rol dos conceitos operativos no trabalho de análise dos espetáculos. Antes, faz-se necessário, portanto, formalizar certa distinção entre texto e representação no contexto da montagem teatral. Anne Ubersfeld alerta para sua importância uma vez que “não é possivel examinar com os mesmos instrumentos os signos textuais e signos não verbais da representação”497. Assim, 1) “a matéria de expressão do texto é lingüística, a da representação é múltipla, verbal e não-verba”498; 2) é dito sincronicamente, numa leitura linear, em oposição ao caráter sincrônico dos signos da representação. De modo que o texto de teatro está "presente no interior da representação sob a forma de voz, phoné»499. É um dos componentes da representação teatral, precede-a e a acompanha, além de poder ser lido como um romance. Compõe-se basicamente de duas partes: o diálogo e as didascálias. A citação de Ubersfeld se deve à sua precisão na definição dos dois conceitos:

Mesmo quando parecem inexistentes, o lugar textual das didascálias nunca é nulo, pois elas abrangem o nome das personagens, não apenas na lista inicial, mas no interior do diálogo, e as indicações de lugar; respondem às perguntas quem? e onde? O que as didascálias designam, pertence ao contexto da comunicação; determinam, pois, uma pragmática, isto é, as condições concretas de uso da fala: constata-se como o texto das didascálias prepara o emprego de suas indicações na representação (onde não figuram como falas).

A distinção lingüística fundamental entre o diálogo e as didascálias tem a ver com a enunciação, isto é, com a pergunta quem fala? No diálogo, é este ser de papel que chamamos de personagem (distinta do autor); nas didascálias, é o próprio autor que:

a. nomeia as personagens (indicando a cada momento quem fala) e atribui a cada uma um lugar para falar e uma parte do discurso;

b. indica os gestos e as ações das personagens, independentemente de qualquer discurso.

Feita esta distinção, reproduzir-se-á abaixo, ao longo dos comentários e exames das montagens em foco, trechos dos quatro textos de teatro apenas como referência do ponto de partida (ou do ponto de chegada, dependendo do método utilizado no processo de criação)

\footnotetext{
${ }^{497}$ Ubersfeld, Anne. Ler o teatro, p.5.

${ }^{498}$ Ubersfeld, Anne. Ler o teatro, p.7.

${ }^{499}$ Ubersfeld, Anne. Ler o teatro, p.5.
} 
para transposição, concretização e objetivação do espetáculo teatral. Cabe lembrar que o trabalho de análise recairá sobre seqüências filmadas da encenação teatral, portanto, referirse-á de preferência aos signos não verbais: a sintaxe proxêmica, os códigos visuais e musicais, o sistema dos objetos etc. A complexidade do signo teatral está ligada a sua polissemia e ao seu empilhamento vertical de signos simultâneos, o que permite "dizer muitas coisas ao mesmo tempo, de construir várias narrativas simultâneas ou entrelaçadas” ${ }^{500}$, enfim, o contraponto, em seu evolver no eixo sintagmático.

\section{A imagem poética do TEC}

\section{Soldados}

Contextualização: Esta peça, Soldados, baseada na novela La Casa Grande de Alvaro Cepeda Zamudio, tornou-se um emblema da busca pela dramaturgia nacional na Colômbia. A partir da adaptação de vários capítulos da novela, feita por José Carlos Reyes, foram surgindo novos textos de outros autores que giravam em torno do mesmo tema: o massacre das bananeiras de 1928. Em entrevista com o próprio José Carlos Reyes, ele afirmou que foi um período muito rico do teatro colombiano, efervescente; que este texto provocou a imaginação da gente de teatro que se interessou e desenvolveu o tema, propondo novos textos a partir de novos pontos de vista, estabelecendo um verdadeiro diálogo entre as diversas montagens e propostas textuais cobrindo assim o espetro das vozes envolvidas no acontecido. Como, por exemplo, a primeira versão feita pelo TEC, em que Enrique Buenaventura ao ouvir crítica pela ausência dos trabalhadores em cena, retormou o processo de criação para uma nova versão da montagem. Era verdade, naquela primeria versão, só os soldados estavam ali, mostrava-se apenas os conflitos e contradições que envolviam os soldados que apresentavam apenas um ponto de vista da questão. Porque não mostravam a greve propriamente? Porque não mostravam o dilema dos trabalhadores?

A partir destas considerações e sempre tentando dar respostas consistentes aos problemas que o público apontava, a montagem do TEC acabou por ter cinco versões distintas, nas últimas das quais, Buenaventua acabou por reescrever parte do texto ao

\footnotetext{
${ }^{500}$ Ubersfeld, Anne. Ler o teatro, p.13.
} 
enxertar nele outros discursos. Antes da montagem de Buenaventura, houve a de Santiago García ainda em 1966.

Mas o que foi esse acontecimento histórico do massacre exatamente? Para falar da montagem Soldados do TEC, é preciso antes se referir a esse fato sangrento da história da Colômbia. O massacre das bananeiras foi resultado da brutal repressão à greve dos trabalhadores da empresa norte-americana United Fruit Company, ocorrido em Santa Marta, em 1928. Foi um marco na história política do país, em função de deixar registrada uma das primeiras manifestações do nível de organização a que a classe camponesa e trabalhadora alcançara. Organização que vinha se desenvolvendo desde finais do século XIX. No centro da questão encontrava-se o problema da terra, da desapropriação das massas camponesas pelos latifúndios, prática que remonta também ao século XIX.

De forma esquemática, pode-se resumir esse período do seguinte modo:

ao sair os paises latino-americanos da época das lutas emancipadoras, economicamente passaram da 'primeira fase da dependência', que se iniciou no momento mesmo em que os países ibéricos impuseram uma estrutura sócio-cultural baseada numa economia de exploração, a uma 'segunda fase', que se estenderia até a Grande Depressão nos anos 30 do presente século. [...] [etapa] baseada no convencimento de que o cobrir as necessidades das economias mais avançadas, abastecendo-as de produtos primários agrícolas e minerais, geraria “a la larga” um crescimento econômico local ${ }^{501}$.

$[\ldots]$

A América Latina continuava representando aos olhos da economia norte-americana e européia, uma grande possibilidade de lucros, ou seja, "novos mercados de onde extrair suas matérias primas e principais produtos de consumo”. Com na maior parte dos países latino-americanos, a base da economia da Colômbia era a produção agrícola: primeiro o café, “seguido pelo algodão, tabaco e mais tarde a banana”. Beatriz Rizk traz um resumo da política deste período:

A partir de 1860, o governo começou a se preocupar em incrementar o desenvolvimento econômico na área rural por meio da criação do Ministério da Agricultura, protocolando as primeiras leis protecionistas dos colonos: a lei 61 de 1874, e a 48 de 1882, nas quais praticamente dava a terra a quem a cultivasse com êxito. Entretanto, [...] grandes latifundiários conseguiram apropriar-se das terras públicas usando

\footnotetext{
${ }^{501}$ Rizk, Beatriz. La dramaturgia de la creacion colectiva, p.180-181.
} 
qualquer recurso que tivessem à mão, legal ou não, para desalojar os colonos e anexar as terras a extensos latifúndios, [...] [entre outros interesses havia aquele] de especular com a terra fazendo grandes negócios com companhias estrangeiras.

Foi num desses grandes negócios, associado às concessões dos governos, que a companhia norte-americana exportadora de bananas, United Fruit Company, com base em Boston, “chegou a possuir 256.000 acres de terra na Costa Norte da Colômbia”,502.

O deslocamento de grandes levas de camponeses provocado tanto pela desapropriação sistemática de suas terras quanto pelas inumeráveis guerras civis, gerou uma imagem completamente diferente daquela comum na América Latina, segundo a qual o agricultor ou colono era um homem apegado à sua terra. Na Colômbia, esta mobilidade de grupos e povoados inteiros, levava a uma intercomunicação que difundia onde havia maior possibilidade de trabalho. "De modo que, quando a United Fruit Company se instalou próxima do porto de Santa Marta, e começou [...] o cultivo de banana, foram muitos os trabalhadores [...] que se apresentaram atraídos pela possibilidade de melhora econômica através de contratos de trabalho" ${ }^{\circ 03}$.

Rizk indica ainda que os antecedentes mais antigos referentes à organização dos tabalhadores na Colômbia foram as chamadas Sociedades Democráticas de Artesãos em meados do século XIX. Depois disso, vieram as primeiras greves: a da estrada de ferro do Pacífico de 1878; e a dos trabalhadores do Panamá, em 1884. Mas os sindicatos propriamente ditos só apareceriam no começo do século XX, como resultado da influência das revoluções russa e mexicana bem como da difusão do pensamento marxista. É desse período a criação da maioria dos partidos comunistas na América Latina.

Na década de 20, no fim da qual se dá o massacre das bananeiras, aconteceria também o Segundo Congresso Obrero (1925), seria criada a Confederación Obrera Nacional, substituída um ano depois pelo Partido Social Revolucionário (PSR), além da ocorrência de três grandes greves: em 1924, em 1927 e em 1928. A primeira seria na Tropical Oil Company, em Barrancabermeja; a segunda outra vez na Tropical Oil e a terceira na United Fruit Company, todas elas desbaratadas por meio das balas dos soldados, ainda que já começasse o esforço de difundir entre trabalhadores e soldados “o

\footnotetext{
${ }^{502}$ Legrand, p.55 apud Rizk, B., op. cit., p.182.

${ }^{503}$ Rizk, B., op. cit., p.182.
} 
reconhcimento mútuo de interesses de classe", como lemas tais como: "não temais às baionetas, não temais aos fusis, pois estão nas mãos de vossos irmãos de classe e eles não dispararão sobre vossos peitos”.

Mas a verdade é que atiraram e é justamente este confronto entre soldados e grevistas que levou a um dos maiores massacres contra os trabalhadores na Colômbia, o assunto da novela de Cepeda Samudio e da adaptação de Carlos Jose Reyes. Uma das grandes obras de referência da Literatura Latino-Americana que também trata desse tema é Cem anos de solidão de García Márquez. As reivindicações dos trabalhadores das bananeiras podem ser encontradas no próprio texto da peça:

\section{Boga:}

1. Que se nos reconozca como trabajadores de la compañia por medio de un contrato de trabajo y se termine con los capacetesde acuerdo com las leyes colombianas.

2. Que se nos pague el descanso dominical, se nos reconozcan los accidentes de trabajo y el servicio médico, tal como exigen las leyes de Colômbia.

3. El salario mínimo, que en la actualidad es de 80 centavos, pedimos que se aumente en un 50 por ciento.

4. Que se construyan escuelas de acuerdo con las leyes colombianas, ya que la única escuela que había se há convertido en un bar.

5. Que se acabe com los comisariatos de la compañia y el pago en vales y se permita abrir tiendas y comprar lo que uno puerda donde uno quiera.

La Ciénaga, octubre 6 de 1928. Firmado por todos los representantes de la Unión Sindical de Trabajadores de la Compañia (p.170-171).

De acordo com Beatriz Rizk, Soldados do TEC estréia sob a autoria coletiva de Carlos José Reyes, Enrique Buenaventura, Jacqueline Vidal, e os quatro atores: Jorge Herrera, Sergio Gómez, Gilberto Ramírez, y Guillermo Piedrahita. Aos personagens originais da adaptação (os soldados que às vezes se convertem em trabalhadores), “o TEC lhe acrescenta um 'tamborillero' que se presta a múltiplos serviços: faz as vezes de sargento”, de narrador omnisciente, de presidente do país, de gerente da United e do general Cortés Vargas, y um advogado que representa os trabalhadores da companhia”,504. Quando a peça foi apresentada ante os velhos trabalhadores das bananeras, testemunhas da greve, deu início a mudanças que geraram novas versões, momento em que a peça sofreu, segundo Rizk, “mudanças transcendentais”: de mera “ ‘essencia mítica’ do acontecimento”

\footnotetext{
${ }^{504}$ Rizk, B., op. cit., p.186.
} 
passou-se a "um verdadeiro teatro-documento". A reprodução do relato de Buenaventura sobre essa peça é importante para mostrar um dos pontos centrais do Nuevo Teatro, a relação palco-platéia. Esse relato foi dado numa entrevista pessoal do encenador colombiano à pesquisadora Beatriz Rizk, a cujo texto este trabalho vem se referindo. Com relação a apresentação da peça aos antigos grevistas das bananeiras, ele diz:

A reação deles foi negativa. "Mas sim está bem, estão os soldados, mas aí não está a greve”. E nós ficamos pensando. Sim, é verdade, na peça os soldados falam da greve, mas não há greve... Então nos dedicamos a ir às bibliotecas para investigar como havia sido essa greve. E descobrimos uma quantidade de documentos nas bibliotecas, desempoeiramo-los e os tiramos. Hoje em dia estes documentos estão publicados... E então montamos a segunda versão. Mas como nesta segunda versão os elementos da primeira e da segunda não casavam bem, fizemos uma terceira e assim até que fizemos cinco versões de Soldados $^{505}$.

Influenciado por Peter Weiss, enxertam-se na obra documentos supostamente tomados de fontes originais, tais como: “os discursos de Abadia Méndez, a correspondência telegráfica entre este e o general Cortés Vargas, o edito promulgado pelo primeiro condenado à morte aos grevistas”, além dos “comunicados oficiais da companhia firmados por Thomas Brandshaw (gerente da United), as ‘memórias do general Cortés Vargas', etc”. Essa experiencia da montagem de Soldados seria de extrema importância para a trajetória e para o amadurecimento do TEC. Segundo Rizk, “entre as obras mais notáveis do Nuevo Teatro sobre este evento, em sua busca histórica por temas nacionais, temos A greve (1970), de Jaime Barbín com o coletivo do Teatro Ação; O sol subterrâneo (1975) de Jairo Aníbal Nino e a próxima do TEC, e A denúncia (1973), escrita por Buenaventura”506.

Fábula da peça. Nesta obra, os soldados estão completamente humanizados. O grupo usou a condensação e o deslocamento para conseguir determinados efeitos. O primeiro soldado está atrás de seu irmão que trabalha nas bananeiras, e o segundo está mais preocupado em comer e em "ver mulheres" do que resolver a questão dos grevistas. No final, o soldado número dois, preocupado com comida e mulheres se evade do massacre escondendo-se num prostíbulo. O conflito central da obra, na leitura de Rizk, encontra-se

\footnotetext{
${ }^{505}$ Buenaventura, E. Entrevista pessoa concedida a Beatriz Rizk em obra já citada, p.187.

${ }^{506}$ Rizk, B., op. cit., p.180.
} 
nessa confrontação soldado/trabalhador, como o grupo se daria conta mais tarde: “O fato de que os mesmos atores que interpretaram os soldados fizeram os trabalhadores, cosntruía uma imagem profunda significante no texto, porque o soldado é um trabalhador disfarçado e o disfarce o faz cometer barbaridades. Isto o percebemos muito tempo depois”. Além disso, os soldados vinham das mesmas classes populares que compunham a classe dos trabalhadores.

\section{A imagem poética da encenação da peça: Soldados do TEC}

A seqüência reproduzida no filme tem a duração total de: 0h13m39s.

Seqüência 1: dois trechos da "Marcha dos soldados": do intervalo de 0h04m04s a 0h4m46s; e do, de 0 h07m11s a 0h08m03s.

Nestes dois trechos, assiste-se à atividade dos soldados. A cena chama atenção pelo recurso altamente teatral que consiste em mostrar com apenas dois atores um grupo de soldados ou um pelotão. O recurso teatral consiste na repetição do fragmento de uma mesma cena pelos dois soldados, dando a impressão de serem outros soldados que estão executando as ações. O desenho de cena composto pela postura e movimento dos soldados indica claramente o método da observação e da mimese, ou seja, pesquisa da partitura corporal da vida cotididana e prática dos soldados. Indica também o cuidado e a preocupação com a transposição desta pesquisa para a cena, transformando os gestos cotidianos do exército militar num gestual elaborado artisticamente. Além da repetição, outro recurso utilizado é o da montagem, segundo a definição de Eisenstein. Por meio da reunião de fragmentos de uma imagem/representação similar à da vida cotidiana, emerge a imagem teatral e poética de um tipo de instituição criada pelo Homem, para exercer e controlar os povos pelo uso de sua coerção a base da força.

Seqüência 2: de 0 h08m04s a 0h08m27s.

Aqui, tem-se o mesmo recurso empregado nas seqüências dos soldados, mas agora a partir de outro ponto de vista. Ele foi utilizado para mostrar um grande número de trabalhadores em greve com apenas quatro atores. O recurso da repetição do gesto de chamar os companheiros para uma suposta assembléia também pressupõe pesquisa. E um dado interessante observado pelo próprio Enrique Buenaventura é o fato de que os mesmos atores que interpretaram os soldados, representam os trabalhadores da empresa 
norte-americana em greve, o que acabou gerando um novo signo, acabou se tornando um dado significativo. Pode revelar ao espectador a origem comum dos trabalhadores e dos soldados, ou seja eles advêm da mesma classe social.

Seqüência 3: da resposta da United Fruit Company: 0h09m32s a 0h10m21s

A teatralidade do objeto de cena: o uso do capacete como um globo terrestre no qual são apontados países onde a companhia poderia se instalar com facilidade.

Seqüência 4. da "dança da morte”: 0h10m22s a 0h13m29s

Nessa seqüência, assiste-se a uma das cenas mais chocantes do espetáculo. E usa beleza está aí, nesta “poética do choque”. Paradoxalmente, ela recria justamente o momento em que o exército atira contra os trabalhadores reunidos na praça central de Santa Marta. E não deixa de ser um recurso do efeito de distanciamento o recriar da tragicidade de uma cena histórica de forma plasticamente elaborada. A chacina dos 
trabalhadores não é mostrada de forma realista, ao contrário, é recriada como uma dança, a dança da morte. O tormento do grito lancinante ecoa no tempo, gera ressonâncias e reverberações internas no espectador ao recuar aos primórdios do genocídio fundador do conjunto dos países da América Latina. A imagem de um ritual emerge da cena. Trata-se de mais sacrifícios humanos no tortuoso devir latinoamericano.

É possível detectar nesta cena ecos de ensinamentos de Meyerhold. De forma indireta, muito dos princípios meyerholdianos foram difundidos, adotados e tornados senso comum na cena teatral contemporânea. Mesmo que a construção desta cena esteja muito distante daquela dos atores acrobatas da biomecânica, não é possível deixar de perceber a corporeidade e a fisicalidade da cena bem como a plasticidade do movimento e dos corpos em movimento. Há ritmo, desenho e símbolo. O giro ou a aspiral no que se está chamando aqui de “dança da morte” combinado com o grito erige um espaço que traz ecos do passado e prognóstico do futuro. Há condensação num só instante do passado, presente e futuro. As batidas que acompanham o movimento é tanto o som de uma estocada de tiros mortais quanto a percução de um ritual de sacrifício. Esta dança da morte não representa apenas a brutalidade de uma execução sumária de trabalhadores em seu livre direito de reivindicação de melhores condições salariais e laborais. Ao evocar o passado e o futuro, cria um momento de verdade que revela todos os assassinatos injustamente perpetrados contra os desejos e vontades do povo. Esta dança da morte é o sacrifício que uma grande parcela da humanidade teve que pagar para que a América Latina pudesse existir. E denuncia implicitamente a probabilidade de sua recorrência no futuro se esta história permanecer no desconhecimento, o que a montagem da peça resolve em parte tornando público um evento “mal-contado" pela história oficial.

A imagem poética foi sendo tecida a partir de todos os elementos compósitos desde o início do espetáculo e explode nesta cena final, em seu auge, fazendo emergir a partir de sua relação com todas as cenas anteriores, a plenitude e concretude de uma imagem teatral carregada de sentido. 


\section{La Orgía}

La orgía faz parte do ciclo de Los papeles del infierno

A peça La Orgía faz parte de um ciclo de peças de um ato, chamado Los papeles del infierno, em que Buenaventura explora a dificuldade e a periculosidade de se aceitar termos fechados e cordatos tais como "tradição" e "História” em sociedades aniquiladas pela violência ${ }^{507}$. Segundo Diana Taylor, “a própria estrutura da composição do ciclo em si mesma reflete ruptura e descontinuidade", ${ }^{508}$ pois o ciclo é composto de peças curtas, fragmentos, partículas que acabam por lembrar peças de um mosaico, o que não deixa de ser uma referência direta ao dilaceramento da sociedade colombiana em virtude da crise dos anos de "la violência", esquematicamente descrita no capítulo 1.

Diana Taylor observa em seu estudo a discordância sobre quantas ou quais eram exatamente essas peças que compunham o ciclo. Ou, ainda, em que ordem elas teriam aparecido. Para esclarecer isso, ela faz um pequeno histórico, informando sobre a discordância entre os diferentes registros: “o jornal Tramoya, por exemplo, publicou nove peças em 1979; Fernando de Toro se refere a quatro; Penny Wallace lista oito títulos: La Maestra, La Autopsia, La Requisa, La Tortura, El Entierro, La Orgia, El Menu, e O Sonho.” E acrescenta a seguinte informação, “a antologia de Errol Hills, A Time and a Season: Eight Carribean Plays, inclui La Orgía bem como uma peça não listada em nenhum outro lugar, O funeral (ou El Entierro), como representativas do ciclo"509. Mas a versão adotada por Taylor é aquela expressa na obra do próprio Buenaventura e de Carlos José Reyes. Segundo suas palavras:

A coleção do trabalho de Buenaventura de 1977, Teatro, lista cinco peças como constituintes do ciclo: La Maestra, La Tortura, La Autopsia, La Audiência, e La Requisa, embora o livro inclua também El Menu e La Orgia, que de acordo com a introdução de Carlos José Reyes, também fazem parte do ciclo ${ }^{510}$.

Seguir-se-á esta versão a exemplo de Taylor. Deste modo, o ciclo de “Os papéis do inferno” se comporia então de sete peças ao todo; distintas, cada uma com uma duração

\footnotetext{
${ }^{507}$ Taylor, Diana. Theatre of crisis, op. cit., p.187.

508 "The very structural makeup of the cycle in itself reflects rupture and discontinuity". In:Theatre of Crisis, 187.

${ }^{509}$ Taylor, Diana. Theatre of crisis, op. cit., p.

510 Taylor, Diana. Theatre of Crisis, op. cit., pp.187-188.
} 
diferente: as curtas durando menos de 10 minutos, enquanto as mais longas não ultrapassariam uma hora de espetáculo.

A imagem que Taylor utiliza para descrever essa obra seria a de uma espiral como sugerida pelo próprio Buenaventura em seu texto Atos de Habla ${ }^{511}$. Cada peça representaria uma volta sempre em torno do mesmo tema, no caso, o da violência, de modo que, à cada volta do ciclo esse tema se dilataria cada vez mais. Assim, na primeira volta dessa espiral, estariam incluídas as três primeiras peças: La Maestra, La Tortura e La Autopsia (“A professora”, “A tortura” e “A autopsia”); na segunda, La audiência e La Requisa (“A audiência” e “A requisição”); e, finalmente, no terceiro giro, as duas últimas peças mais longas: El Menu e La Orgia (O Menu e A orgia). Estas peças, como outras de Buenaventura, não têm um modelo rígido e seu começo abrupto e fim inesperado “destroem as noções aristotélicas de uma representação teatral contínua como um universo estético integrado com começo, meio e fim”. ${ }^{512}$ Do conjunto de peças que compõem Los Papeles, a que interessa particularmente nesse trabalho é a que encerra esse ciclo: a peça chamada A Orgia. Entretanto, para chegar a ela, é necessário se deter sucintamente nas outras peças que formam o quebra-cabeça. Para usar ainda uma vez a imagem de Buenaentura/Taylor, tome-se o primeiro giro da espiral, onde se situam as três primeiras peças, cujos três pontos de vista são distintos com relação ao mesmo evento, a saber, a violência: o ponto de vista da vítima (a professora), o do carrasco (o torturador) e o do colaborador (o médico de A autopsia). Como indica Taylor, embora os personagens pareçam existir de forma isolada, cada um na sua própria peça, “ecos fortes os ligam em conjunto”.

Na peça La Maestra, tem-se inicialmente a professora sentada sozinha no palco que informa ao espectador que está morta. "Ela se deixou morrer ao recusar comer e beber, depois que seu pai, fundador da cidade, foi morto pelos militares que depois a violaram”. Como afirma Taylor, a professora recorda a perda de seu mundo. Ela fala de um passado longínquo que quase toca o mito da criação cristã. Não há espaço para ela e sua experiência dentro da nova estrutura de poder que se instala. Quando o soldado que mata o pai a rapta,

\footnotetext{
511 Buenaventura, E. Diário de Trabalho. Texto digitado, ainda não publicado, cedido pela esposa do encenadora, Jacqueline Vidal, p.

512 Taylor, D., Op. Cit., p.189. “The abrupt stars e stops of the short pieces undermine all Aristotelian notions of a continuous performance as an integrated aesthetic universe with a beginning, middle, and end”.
} 
tenta se explicar, insistindo que ele pessoalmente não tem culpa: "Ele está cumprindo ordens daqueles que querem remover os 'caciques e os parasitas do antigo regime”, ${ }^{513}$ Do mesmo modo, em La tortura, o carrasco "também enfatiza que ser um torturador é igual a um trabalho como outro qualquer, como ser doutor ou açougueiro”. Você já viu um doutor ou um açougueiro honesto doente por escrúpulos? Quando sua esposa discute por causa de sua ocupação, ele a acusa de hipocrisia porque ela se beneficia do que ele faz: "para cada unha que ele arranca dos dedos de suas vítimas, ela ganha um novo par de meias.” O mesmo acontece com o médido “legista” de A autópsia. Ele também reivindica estar apenas fazendo o seu trabalho. Se ele falsifica evidencias para provar que vítimas brutalizadas morreram de morte natural, bem, 'isto é porque o mundo é um matadouro’. Mesmo quando isso acontece ao próprio filho. Ele se pergunta; o que se pode fazer? ${ }^{514}$

Na seqüência, tem-se duas outras peças: A Audiência e A Requisição. Na primeira, reúnem-se em cena vítima, perseguidores e colaboradores, cada um se escondendo por detrás de sua máscara, numa poderosa farsa judicial. Como analisa Taylor, "a fraude no julgamento legitima o processo de extermínio”. A violência aqui não é pontual, mas generalizada a toda a sociedade, de modo que os personagens começam a viver constantemente em função da ameaça desse terror. A suspeita e o temor contaminam as relações entre todos os personagens.

O "adepto do crime" (como o torturador) se sente mal pago e caluniado; os profissionais (com o doutor) temem pela suas vidas e posições; a vítima é um "personagem" anônimo e silente, cuja presença é necessária primeiramente para fazer a fraude funcionar. A hostilidade não canalizada no palco alerta-nos que a crise excede muito o delito alegado atribuído ao acusado - um homem constrangido, exposto, que não profere uma palavra durante todo o processo. ${ }^{515}$

O efeito disso no espírito do espectador é a percepção da ocorrência de uma espécie de inversão: na trilha de Taylor, inversão da mecânica da perseguição com relação à causa e

\footnotetext{
513 TAYLOR, D. Op. Cit., p. 189-190.

514 TAYLOR, D. Op. Cit. p.189.

515 TAYLOR, D. Idem. Ibidem, p.190. "The henchmen (like the torturer) feel underpaid and maligned; the professionals (like the doctor) fear for their lives and positions; the victim is a silent, anonymous player whose presence is necessary primarily to keep the sham functioning. The unchanneled hostility onstage alerts us that the crisis far exceeds the alleged misdeeds attributed to the accused - a naked, bound man who does not utter a word throughout the entire proceeding”.
} 
natureza da violência: “a vítima, que é percebida como cause (ele é um 'comunista’) é de fato o result da crise". 516

Na segunda, A Requisição, é perceptível sua associação temática com a anterior. Só que o foco aqui é a ação dos “bons rapazes”. Nessa peça, fica evidente que é difícil para as lutas revolucionárias sobreviverem numa sociedade criminosa, muito menos tornarem-se heróis automaticamente os grupos de luta. “Ele são também produtos de uma sociedade em crise, vítimas de brigas internas, contradições ideológicas (especialmente sexismo aqui), e pontos cegos.” Para não cair numa ingenuidade nada salutar, Taylor propõe examinar a idéia de "heroísmo”. Diz ela que o "herói revolucionário tem junto laços financeiros com o pai anti-revolucionário. Que ele mente para sua esposa, infantilizando-a tanto quanto para seu cunhado também antirevolucionário”. A contradição aumenta na medida em que a peça se desenrola para um desfecho fatal: o assassinato de um dos revolucionários, o que leva a perspicácia de Taylor a concluir:

A esperança de descolonização, que Buenaventura enfatiza em todo o ciclo, não está na confiança dos oprimidos em si mesmos de que eles são diferentes de seus opressores, mas na verificação deles do que os faz o mesmo e em que grau eles internalizaram seus opressores. No fim, "He" é morto pela polícia, e sua esposa e companheiros glorificam seu martírio. Numa ironia perturbadora, aqueles que se juntam aos oprimidos topam com o sacrifício como uma solução um tanto do mesmo modo quanto os opressores fazem: para ambos, "ele morreu para que nós pudéssemos viver. ${ }^{517}$

E enfim na volta mais ampla da espiral, a terceira, encontram-se as duas peças restantes: El Menu e La orgia. Estas são as peças mais longas do ciclo, com enredos complicados, de maior elenco e belos cenários. São peças complexas, engraçadas e grotescas que "reúnem vítimas, carrascos e colaboradores na representação da opressão e do colonialismo”. Na primeira, a trama central refere-se a um banquete oferecido para a introdução e lançamento de um novo candidato às “esferas mais altas da sociedade”. Entre a elite, alguns mendigos selecionados, um cego, um aleijado sem as duas pernas, um guru

\footnotetext{
${ }^{516}$ Grifo do autor.

517 “The hope for colonization, Buenaventura stresses throughout the cycle, does not lie in the oppressed's assuring themselves that they are different from their oppressors but in the scrutinizing what makes them the same and to what degree they have internalized their opressors. In the end, "He" is murderer by the police, and his wife and companions glorify his martyrdom. In a disturbing irony, those who side with the oppressed hit upon sacrifice as a solution in much the same way as the oppressors do: for both, "He died so that we might live”. Taylor, op. cit., p.191.
} 
de circo, um Fakir, e uma adivinhadora, chamada "Iniciada 1", são permitidos participarem porque eles de algum modo divertem as senhoras. Como afirma Taylor, entre outras funções, "a presença de mendigos - apesar de serem rigorosamente controlados e basicamente ‘simbólicos', ... - é indispensável na farsa dedicada à democracia e integração social ${ }^{, 518}$.

Finalmente, chega-se à peça La Orgia, a última peça que “fecha” esse ciclo. Antes de continuar, porém, é preciso rememorar algo já esquemática e sucintamente tratado acima. Viu-se a ordem das peças, de que modo elas partem de um ponto, e de que de forma espiralada vai se ampliando vertical e horizontalmente até tocar em situações resultantes de desdobramentos ou conseqüências de segundo grau, cujas causas estão lá no ponto inicial. Até agora, restringindo-se ao dado no corpo do texto, tem-se: a violência primordial expressada na aniquilação do mundo antigo da professora, que se desdobra num movimento mais amplo de perseguição desenfreada a todos os suspeitos de subversão, desembocando por sua vez na detecção da ampliação da rede social por meio do comprometimento de indivíduos com a violência institucionalizada, representada pelo grupos dos colaboradores. O trilho da violência sobe seu caminho com a farsa do processo judicial e com a denúncia da contradição dos revolucionários; enfim, chega-se ao banquete beneficente com toda a sorte de crueldade disfarçada de caridade. A Orgia representa no interior deste quadro, o desdobramento do desdobramento; como se se quisesse dar forma aos níveis de degradação a que essa violência pode levar ao alcançar as franjas da sociedade, a beirada onde se amontoam as multidões que conformam a base da pirâmide social. Apenas ao se refratá-la, como num olhar para trás, percebe-se o vínculo orgânico entre todas as peças do ciclo, ainda que ao examinar o fio da violência que liga todas as peças, encontra-se não uma totalidade orgânica como quer a arte clássica, mas o pressentimento dessa totalidade, cujas cenas aparentemente isoladas são expressões de uma mesma origem, cujas distintas facetas explodem unitárias na concretude da realidade. Que se continue então com La Orgia.

\section{La Orgia}

518 Taylor, op. cit., p.190-191. 
Nessa peça, o enredo pode ser resumido do seguinte modo. Uma mulher velha, feia, degenerada, mãe de um filho mudo, paga a um grupo de mendigos uma pequena quantia em dinheiro e uma refeição pobre para que eles vistam os trajes de seus antigos amantes, a fim de rememorar os tempos gloriosos do passado. A evocação mais recorrente dessas lembranças está relacionada ao encontro com um príncipe europeu, o que denuncia na velha seu mal-estar com sua história e sua condição ou algo como um sentimento inconsciente de inferioridade. Ou talvez aquilo que Otávio Paz falando do mexicano chamou de “enigma”, mas que vale para o conjunto das populações latino-americanas. Enigma que combina a “vergonha da origem” com a "vontade de ser”, o “querer ser diferente” com a "vontade de fantasia"519; ou ainda o que nas palavras ainda mais incisivas de Leopoldo Zea denotaria o “complexo de bastardia expresso no afã inútil por ser distinto do que se é; por ser outro, renunciando ao que se é por si mesmo. Vendo o próprio como inferior àquilo que lhe é estranho e do qual só se considera, eco e sombra”. Este é o homem “que começa a aceitar os critérios do colonizador sobre a cultura materna e americana e, de acordo com eles a inferioridade de sua mestiçagem, que o impede de ser parte legítima da cultura paterna”. Continuando com o autor, "sua mestiçagem, longe de ser algo positivo, será a fonte de toda a sua ambigüidade e ambivalência”, ${ }^{520}$ duas características que persistiriam ao longo da história da cultura do homem latino-americano.

Nesse sentido, é recorrente na fala da "Vieja” proposições tais como: “el Príncipe no volvió nunca más a esta horrible Suramérica de hoy”; ou, “...el Príncipe, heredero del trono de Inglaterra, que hace su primer viaje por Sudamérica, viene a mi vagón”; e, “...El príncipe...me besó la mano en el tren, en Argentina...”; “El príncipe...hizo su primer viaje a Suramérica. E el último. ¿Cómo quieres que venga a esta horrible Suramérica de hoy? ${ }^{521}$

O príncipe representa o máximo da possibilidade de ser em contraposição à terrível realidade do que na verdade se é. A velha não se aceita e nunca se aceitou em sua condição. E o evento mais importante de sua vida, algo digno de consideração, foi exatamente o fato, tantas vezes rememorado, de o príncipe ter beijado a sua mão. Isso é o que se apresenta numa primeira leitura de acordo com o puro enumerar dos fatos internos da peça. Mas ao se

\footnotetext{
${ }^{519}$ O labirinto da solidão, p.17.

520 “América Latina: largo viaje hacia si misma”. In: Ideas em torno de latinoamerica, p.282.

${ }^{521}$ Buenaventura, E. La orgia, ps. 11, 12,14,38,39
} 
olhar de viés, pode-se ver além. Essa velha bem poderia ser uma metáfora ou uma imagem da América, empobrecida, desfigurada, aniquilada, desde que o descobridor europeu aportou nessas terras. A nobreza e a cortesia do gesto da mão direita dissimulariam a verdade do gesto da mão esquerda. Se a Europa (o nobre) estende a mão direita à América (a velha) e se inclina num cumprimento (deslumbramento inicial dos conquistadores), a mão esquerda, por detrás (por meio da dissimulação) a aniquila e arranca seus tesouros com violência e brutalidade. Para corroborar essa idéia, é insinuado na peça que ouve mais do que um beijo na mão entre a que era moça e o príncipe. O fruto desse encontro jamais seria reconhecido pelo pai, ao contrário, seria rechaçado, humilhado e por fim subjugado. De tal ato fundador, nasceria todo um continente, povoado de bastardos. A prole da velha além de bastarda é degenerada. Ela é mãe de um filho mudo representando assim, sem forçar muito, a unidade dos filhos mestiços da América, subjugados ao ponto de perderem sua própria voz. A mãe, antes bela, só podia dar à luz a um ser “inferior”, dada à sua rusticidade. Agora, desgrenhada e desfeita, só podia contar com o silêncio do filho. A mudez do filho representaria essa impotência dos latino-americanos de fazer valer sua vontade e sua voz.

Todos os personagens da peça não têm nome próprio, são designados mais por uma característica (Vieja) ou por uma categoria (mendigos) do que com um nome que o individualiza. Nomeados são apenas os amantes da Velha que estão ausentes ou designados a partir do título que ostentam ou que lhes conferem autoridade: o Coronel, o governador, o bispo.

A amargura da velha, presa ao seu passado, fala da precariedade e da miséria em seu presente. Como diz Taylor, trata-se de "vítimas participando no drama de sua própria humilhação e destruição”. Para pagar o salário miserável aos mendigos, ela rouba dinheiro do filho mudo que ganha a vida engraxando sapatos. A certa altura, os mendigos famintos arrancam seus trajes e fartos com a avareza da velha, matam-na, comem sua comida, e roubam o dinheiro do mudo, que acabava de chegar ao recinto. Enquanto os mendigos fogem, o mudo, ao se dar conta do que aconteceu, vira-se para o público e sinaliza "por que”? E assim, com uma pergunta sem resposta, em suspense, termina a peça.

Há um trecho da peça em que a velha, toda orgulhosa, encena com seus “mendigosatores” a sua história com o Coronel. Então, ela se volta para o Mendigo 3 e começa sua “direção” de cena: “Coronel, organize as tropas. Vou fazer a revista. O Coronel Pardo me 
levava sempre para ver as paradas militares... Os soldados se derretiam sob o sol enquanto eu fazia a revista. Se alguém desmaiava, era fuzilado imediatamente”. A brutalidade e a gratuidade da morte, "se desmaiava, era fuzilado", mostram o processo de naturalização da violência, cuja prática institucionalizada leva à trivialiadade do ato; de tão comum já não causava espanto ou comoção. E a velha se sente orgulhosa ao narrar esse evento, sentia-se até importante. O Mendigo 3 desempenha com maestria seu papel e faz um pequeno mas significativo discurso na pele da autoridade militar. Como diz Octávio Paz, “a hombridade [do latino-americano] é medida pela invulnerabilidade diante das armas inimigas ou diante dos impactos do mundo externo;”522 idéia que está presente na enunciação do Mendigo 3 como Coronel: “Austeridade. Aperta-se o cinturão. A pátria requer sacrifícios”. Se alguém informa que tem tuberculose, a resposta é rápida: “Nada de desculpas”. Aos aplausos e à aprovação da Vilha, Mendigo 3 responde: "Eu estive no exército, Senhora, e fui para a guerra e sei como falam os militares". A esta frase "sei como falam os militares”, fica evidente a crítica à linguagem, à desvinculação entre discurso e realidade, trata-se apenas de um discurso.

Há outra cena de “comédia grossa” especialmente cruel. Na seqüência do diálogo citado acima, ocorre uma encenação da guerra, caindo “mortos” todos os soldadosmendigos. Ao serem encomendadas suas almas pelo anão-bispo, os mendigos começam a “ressuscitar” um a um e a primeira palavra que pronunciam é obviamente: “comida”. Ao que a reposta vem decisiva: “mortos não comem”. Em seguida, é pedido ao Mendigo 1 que, representando o governador, faça um discurso em homenagem à vitória. O discurso do governador-mendigo 1 é uma justaposição livre de palavras soltas, sem nenhuma conexão gramatical entre si:

Dívidas, empréstimos, investimentos ${ }^{523}$ estrangeiros, banquetes da austeridade, desfalques, conspirações, prisões... cárceres, calabouços, embaixadores, rainhas da beleza, ministros, atos de caridade, gerentes, bispo, empresa privada, hierarquias, impostos, greves, atentados, maioria silenciosa, minorias barulhentas, bancos, bancos, bancos...

O vocabulário do poder está tão distante da realidade destes mendigos que eles se tornam incapazes de articulá-lo num discurso minimamente coerente. Deste modo, assiste-

\footnotetext{
${ }^{522}$ O Labirinto da solidão, p.32.

${ }^{523}$ Buenavnetura, Enrique. La Orgía, p.
} 
se a uma enxurrada de termos advindos desse novo vocabulário, ainda em adaptação, e que ainda não é dominado pelo povo. E que também não deixa de ser uma espécie de violência. A violência física é visível e de fácil identificação. Mas a violência da linguagem é muito mais sutil por estar mais próxima daquele processo de naturalização. O “discurso" fragmentado do Mendigo 1, além de denotar a ação dessa violência no âmbito da linguagem, demonstra também a solução artística encontrada pelo artista para dar conta desse nível de violência verbal. O discurso construído por meio da justaposição de substantivos, mesmo que para os mendigos sejam apenas palavras vazias, cujo significado não alcançam, exerce um efeito de choque sobre o telespectador, por que a justaposição obriga as palavras a se confrontarem entre si; como são dispostas numa estrutura linear, a corrente formada pela justaposição de substantivos, paradoxalmente, põe em movimento as palavras num ritmo distinto do daquele da fluidez da sentença completa com todas os seus termos; aqui, ao contrário, por meio do artifício da justaposição, o confronto entre dois vocábulos forçam o movimento para a frente mas em pequenos saltos, como pequenas explosões resultantes do entrechoque dos conceitos suscitados pelas palavras do discurso.

A falta de coesão e lógica interna do discurso mostra o modo desconexo de realização do pensamento do personagem bem como o seu modo de percepção da realidade. O seu discurso mostra como ele enxerga e percebe o mundo: um mundo sem lógica e fragmentado; e de certo modo, ao menos em alguns aspectos, é assim que se dá no modo de vida imposto pela selvageria do sistema da periferia do capitalismo. O discurso fragmentado, desconectado, mostra o abismo existente entre cada idéia, pressupondo um abismo muito maior frente ao qual se movem aqueles personagens e suas misérias, como o abismo que ameaça constantemente o futuro da Colômbia e da América Latina.

É verdade que, de acordo com Taylor, mais peças poderiam ser adicionadas ao ciclo sem que se rompesse seu movimento básico, em função de “o movimento de uma peça para outra não [ser] dialética - não há o outro. Tudo o que temos é uma intensificação do mesmo, uma spirale du pire incluindo mais e mais violência e desolação". 524

\section{A imagem poética de La Orgía}

\footnotetext{
524 Taylor, op. cit., p.191.
} 
O próprio Enrique Buenaventura define La Orgía como a "imagem de uma sociedade através das lembranças de uma prostituta que revive seu passado”. Dirigida por Danilo Tenório, o texto de Buenaventura parece dialogar com elementos do Grotesco, uma linha estética explorada por Meyerhold, como se poderá conferir a seguir.

1. A seqüência reproduzida no dvd tem a duração de: 0h08m02s.

Trechos da seqüência do filme de teatro:

Seqüência 1. Fúcsias - Intervalo de 0h00m08s a 00h02m04s. Inicia-se com o diálogo, transcrito na seqüência, em que a Velha "revive” uma cena em que é cortejada por um “cavalheiro”, seu antigo amante. Em seguida, tem a vez a entrada do Coronel, cujo discurso provoca a briga com o Mendigo Dois. Pode ser pertinente a reprodução do diálogo desta seqüência:

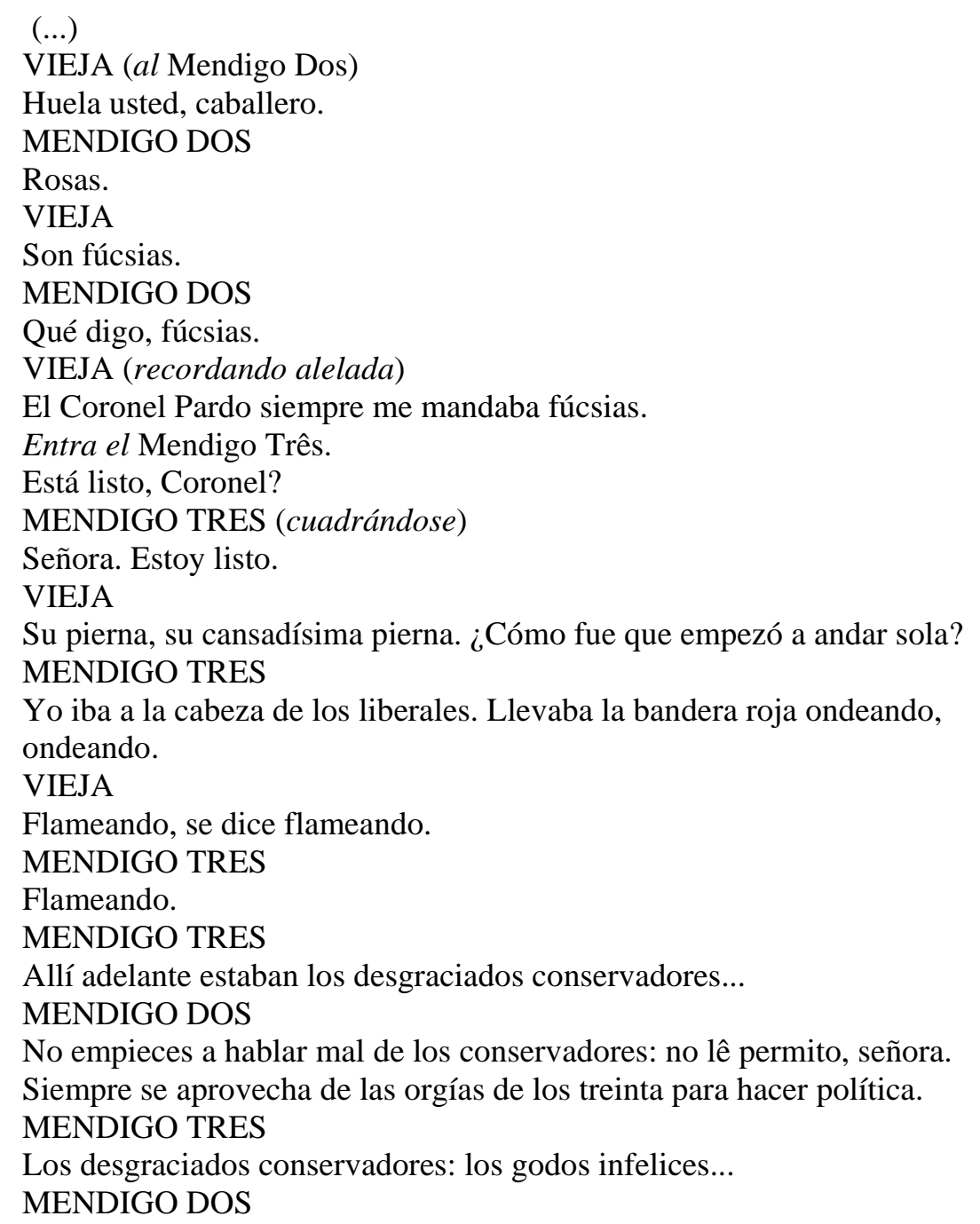


No le permito, señora. No le permito. ¿Quieres perder la outra pierna? El Mendigo Uno se desternilla de risa.

$¿$ ¿uieres perder la otra pierna?

Saca una navaja, oprime el botón y la navaja se abre.

$¿$ ¿uieres tener al otro lado otro palo lleno de gorgojo?

VIEJA

Adoro las batallas políticas.

Al Mendigo Uno.

Jacobo, tu, ¿qué eres?

MENDIGO UNO (cortando la risa y santiguándose)

Cristiano, señora.

Entra la Enana.

ENANA

Ujujuiii: Viva yo.

Pausa. Silencio. La Enana observa la escena.

¿Ya empezó la orgia?

Los Mendigos guardan lentamente sus armas. La Enana se vuelve hacia la Vieja.

Me demoré porque hoy no es treinta. Es veintinueve. Pero esta mañana, en la iglesia, pregunté y me dijeron que era fin de mes. Pero no es treinta, dije. Es año bisiesto, me dijeron. $\mathrm{Y}$ entonces, vine ${ }^{525}$.

(...)

525 Tradução. Velha (ao Mendigo Dois): Arrume você, Cavalheiro.

Mendigo Dois: Rosas.

Velha: São fúcsias.

Mendigo Dois: Que disse, fúcsias.

Velha: El coronel Pardo sempre me mandava fúcsias.

Velha: Está pronto, Coronel?

Mendigo Três: Senhora, pronto.

Velha: Sua perna, sua cansadíssima perna. Como foi que começou a andar só?

Mendigo Três: Eu ia à frente dos liberais. Levava a bandeira vermelha ondeando, ondeando.

Velha: Flamejando, diz-se flamejando.

Mendigo Três: Flamejando. Ali adiante estavam os desgraçados dos conservadores.

Mendigo Dois: Não comeces a falar mal dos conservadores: não o permito. Sempre se aproveita da orgia dos trinta para fazer política.

Mendigo Três: Os conservadores desgraçados: os godos infelizes.

Mendigo Dois: Não o permito Senhora. Queres perder a outra perna?

Mendigo Um (Dói-se de tanto rir): Queres perder a outra perna?

(Tira uma navalha, aperta o botão e ela se abre)

Queres ter no outro lado outra pala cheio de trincas?

Velha: Adoro as batalhas políticas. (Ao Mendigo Um) Jacobe, tu, o que és?

Mendigo Um (Parando de rir e benzendo-se): Cristão, senhora.

Entra o anão.

Anão: Ujujuiii: viva eu.

Pausa. Silencio. O Anão observa a cena.

Já começou a orgia?

Los Mendigos guardam lentamente suas armas. O Anão se volta para a velha.

Anão: Demorei-me porque hoje não é trinta. É vinte e nove. Mas esta manhã na igreja,perguntei e disseram que era fim de mês. Mas não era trinta, disse. É ano bissexto, me disseram. E então, vim. (...). 
Há uma alternância constante do jogo do teatro no teatro: os mendigos, personagens interpretados pelos atores do TEC, representam por sua vez outros personagens dentro da peça. O mendigo Dois, por exemplo, interpreta o cavalheiro, o Três, o coronel, e assim por diante. Esse jogo dos mendigos e da velha de entrar e sair da "encenação da orgia” acontece o tempo todo. Essa alternância vai criando uma tensão que, num crescendo, numa "espiral”, vai explodir no final com o assassianto da velha pelos mendigos. O discurso do "Coronel" denuncia a opção política do Mendigo Três, que é liberal, o que provoca a ira e a reação do Mendigo Dois, que defende o partido Conservador. A discussão entre os dois desemboca numa luta corporal que os leva ao chão. O embate histórico entre os dois partidos colombianos, o Liberal e o Conservador, é concretizado em cena por meio de uma briga de mendigos. O tom de paródia e humor negro que perpassa toda a cena pode remeter claramente ao universo do grotesco cênico ou do grotesco trágico de Meyerhold.

Arlete Cavalieri apresentando os traços de um "novo gênero cênico” que ela identifica na montagem de Meyerhold do texto dramático O Inspetor Geral de Gogol, descreve-os do seguinte modo: essa montagem,

com suas linhas estéticas “deformantes” e "deformadas”, suas proporções aumentadas e suas imagens "exageradas” e de traços "distorcidos” aponta certamente para uma espécie de "bufonaria trágica" que o próprio Meyerhold já tentava definir, em seus escritos teóricos de 1912, onde trata a questão do grotesco cênico ${ }^{526}$.

Essa deformação e exagero podem ser aplicados sem equívoco à La Orgia. Não se trata de "pura utilização de ambigüidades, de caretas e trejeitos, fraturas caricaturescas”, mas da complexidade do “jogo das máscaras, dos gestos e dos movimentos”, cuja retomada no início do século XX por Meyerhold, põe em relevo a descoberta de que se tratava na verdade de um mecanismo encantatório utilizado em várias épocas pelo povo da praça pública.

No grotesco de Meyerhold, “o cômico e o trágico se revezam, alternam-se diabolicamente, para fazer a cena resvalar, de um minuto para outro, da mais terna e sentimental cantiga para a mais cruel e violenta sátira”527. Essa definição do grotesco

\footnotetext{
${ }^{526}$ Cavaliere, Arlete, 1996, p.88.

${ }^{527}$ Cavaliere, Arlete, 1996, p.90.
} 
parece definir plenamente um trecho de uma das seqüências de La Orgía, aquela que se está chamando aqui de balé orgiático. Reporte-se a ela.

FIGURA 3. Seqüência de cenas da peça La orgía Fonte: arquivos do grupo TEC

Seqüência 2 do "balé orgiático" [intervalo de 00h04m28s a 00h05m11s], que pode ser descrita do seguinte modo:

A imagem começa com a tomada em primeiro plano de uma máscara, parece que de gesso, lembrando a fisionomia do cavalheiro estrangeiro que fora amante da Velha na 
juventude. A Velha entoa uma canção melancólica, em ritmo lento, acompanhada por um movimento do corpo todo. Segurando a ponta de um vestido velho, longo, meio em trapos, e que parece ter sido branco um dia, a velha acompanha o murmúrio da canção com um movimento dos braços e tronco, rodeada pelos mendigos. De repente, num grito abafado, como o arremedo de um "êxtase", a Velha despenca, como se fosse "engolida” pelos mendigos. Após o este momento, dá-se início a um baile estranho, um arremedo de dança, uma dança macabra. Os mendigos, com distorção em suas fisionomias devida à miséria, velhice, doença e fome, pulam de forma exagerada e desarmônica, dando uma mostra de como seria se os "mortos vivos" do filme de George Romero de repente resolvessem a dançar. Nessa seqüência, tem-se exatamente esse contraste entre a evocação de um sentimento terno expresso pela canção suavemente entoada e acompanhada por um movimento lento, para a sátira mais deslavada ilustrada na explosão da distorção do arremedo de baile.

De qualquer modo, percebe-se aqui um procedimento artístico que "fala diretamente aos sentidos":

o grotesco cênico de Meyerhold se origina na oposição de diversos tipos de contrastes: no plano da dramaturgia, do jogo do ator, da própria encenação. Assim, a percepção do espectador é constantemente desperta, abalada por um deslocamento contínuo de planos, uma ruptura permanente, pressentida ou imprevista por dissonâncias representadas cenicamente $^{528}$.

Recorre-se agora à citação que Cavaliere faz do próprio Meyerhold em seu esforço de definição do termo:

O grotesco é uma exageração deliberada, uma reconstrução (desfiguração) da natureza, uma união de objetos considerada impossível tanto no interior da nautreza quanto em nossa experiência cotidiana, com grande insistência no aspecto sensível, material da forma assim criada...[...]. [...] O teatro enquanto combinação extramaterial de fenômenos naturais, temporais, espaciais e numéricos que, de modo constante, contradizem o cotidiano de nossa experiência, é, em sua própria essência, um exemplo de grotesco. Nascido do grotesco da mascarada ritual, o teatro será inevitavelmente destruído à menor tentativa de suprimir-lhe o grotesco, pois este é o princípio de sua existência.

\footnotetext{
${ }^{528}$ Cavaliere, Arlete, 1996, p.90.
} 
Obviamente, muitos pontos discordantes existem também entre o grotesco de Meyerhold e o do Nuevo Teatro, entre os quais, poder-se-ia apontar a opulência e o requinte do teatro meyerholdiano, justificado na montagem em foco, pelo fato de as situações se passarem num ambiente burguês. Contrariamente, o grotesco do Nuevo Teatro pode ser compreendido como um aliado à “estética da fome” do cinema de Glauber. A pobreza material e de recursos do teatro latino-americano converte-se em princípio estético duplamente reforçado ao criar no palco a "realidade” da mendicância e sua eterna busca por comida.

Todo o conflito da peça gira em torno de uma panela de sopa. A velha só quer dar a sopa após a encenação da orgia, esse é o trato da "orgia dos trinta”, a festa que a mendiga oferece uma vez por mês aos seus amigos mendigos como recurso para rememorar seus áureos tempos. Mas a fome ancestral dos mendigos impedem-nos de esperar até o fim da “festa” e a todo momento tentam se apoderar da panela de comida.

Seqüência de “O beijo do cavaleiro”: de 0h02m05s a 0h02m58; e procissão: 0h03m00s a 00h04m24s.

(...)

Lentamente, el Mendigo Três, imitando al príncipe heredero, se acerca a la Vieja, le besa la mano y en profundo secreto le dice.

MENDIGO TRES

I love you...

VIEJA

Yes....yes ${ }^{529} \ldots$

$(\ldots)$

Segue uma seqüência de gestos sem fala. A voz do Mendigo Três ao declarar seu amor à velha soa mais a um grunhido, com seu som gutural, grave e incomprensível do que propriamente a uma declaração de amor. O tosco da cena comove. Ao realizar o oposto do que deveria ser uma cena de amor, a paródia de que fala Meyerhold mais uma vez se instaura. O Mendigo Três continua beijando a mão da Velha numa careta e com gestos grotescos, enquanto o Mendigo Dois, do outro lado da Velha, estende sobre

\footnotetext{
${ }^{529}$ Lentamente, o Mendigo Três, imitando ao príncipe herdeiro, aproxima-se da velha, beija-lhe a mão e em profundo segredo lhe diz:

Mendigo Três: I love you...

Velha: Yes...yes... (...)
} 
ela uma meia calça e se dobra sobre suas pernas, acariciando-a. O Mendigo Um também está junto do grupo e acaricia o pescoço da velha. A encenação dos mendigos reproduzindo os velhos "bons tempos" da velha explora outra vez elementos relacionados à estética do grotesco por meio do exagero e de distorções tais como apontados acima. A velha parece se divertir ao ser "paparicada” pelos três Mendigos. Enquanto isso, o Anão se veste de Bispo e começa uma espécie de canto litúrgico, dando início a uma procissão “religiosa”, cujo macabrismo fica evidente na dureza dos passos e na distorção da voz, similares outra vez aos personagens dos mortos-vivos de George Romero. No fim da procissão, o Anão rouba a panela de comida e corre com ela acompanhado pelos outros mendigos, quando a Velha, puxando uma navalha, grita para que parem, e rapidamente recupera a panela. Essa seqüência termina com um plano médio congelado na Velha apontando a navalha para o grupo de mendigos.

Nenhuma instituição escapa da crítica da peça. Igreja, Estado e Capital são fustigados cruelmente nas representações feitas pelos mendigos das autoridades, antigos amantes da prostituta: bispo, governador e o cavalheiro. No fundo, todos lutam encaniçardamente para manter a sua própria "panela de comida”.

Seqüências do "Discurso do governador" ao “assassinato da velha”: 00h05m25s a 00h07m53s.

\section{(...)}

\section{VIEJA}

Hable usted, señor gobernador,estamos esperando...

\section{MENDIGO UNO}

Quisiera comer algo.

MENDIGOS

\section{Bravo.}

\section{VIEJA}

Siempre tan demagógico.

\section{MENDIGO UNO}

Deberíamos poder comer a gusto en las malditas orgías de los treinta. ¿Por qué no se puede comer?, pregunto yo, señores. ¿por qué, estando allí la comida, tenemos hambre? ¿En qué consiste, señoras y señores, este enigma? ¿Quién lo habrá de resolver? Tengo el estómago pegado al espinazo, tenemos un hambre de perros, la comida está a mano y no podemos estirar la mano. Que se nos dê de comer en las orgías de los treinta.

Le da la tos.

\section{VIEJA}

Uno de los mejores discursos de uno de los mejores gobernadores en una de las mejores orgias. 


\section{MENDIGO DOS}

No es justo que haya sobras.

MENDIGO TRES Y ENANA

No. No es justo.

VIEJA

Hasta enardece las masas.

ENANA

Cristo repartió los panes y los peces.

MENDIGOS UNO Y DOS

Y los frijoles y las arepas.

MENDIGO UNO

Queremos las sobras.

MENDIGO DOS

Queremos las sobras.

ENANA

Queremos las sobras.

MENDIGO TRES

Queremos las sobras.

TODOS LOS MENDIGOS

Queremos las sobras. Queremos todo.

MENDIGO UNO (destapando la olla)

Todo.

VIEJA

Alto ahí. Reparto la comida cuando me dé la gana.

Agarra la olla.

MENDIGO DOS

Suelta la olla.

MENDIGO TRES

Vieja avara.

VIEJA (luchando)

Brutos. Borrachos inmundos. Ustedes son la porquería. Retirense.

Por un instante los Mendigos retroceden. La Enana queda detrás de ella

y trata de alcanzar la olla com el báculo. La Vieja toma el cuchillo. La

Enana retrocede.

Ustedes son la hez, la mierda. Ustedes no son mis caballeros. Solo abusan de una anciana desvalida que no tiene más que un hijo mudo.

MENDIGO DOS (avanzando)

Se acabó la comedia. Se acabó la comedia.

MENDIGO TRES

Vieja loca. Vieja loca.

VIEJA (tirando una cuchillada)

Atrás, recua de hediondos.

MENDIGO UNO

Vieja asesina. Me ha herido. Me ha herido.

MENDIGO DOS

Vieja asesina.

MENDIGO TRES

Asesina.

ENANA

Ajujiii. Viva la orgía. 
Descargando un baculazo en la cabeza de la Vieja, cayendo ésta hacia atrás sobre la mesa. Los Mendigos caen sobre ella y la golpean y apuñalan. Queda atravesada sobre la mesa. Su cabeza cuelga, sus grises cabellos llegan al suelo. En silencio, los Mendigos devoran la comida. El Mendigo Uno va a salir ${ }^{530}$.

Nesta cena, o Mendigo Um vai representar o governador. Faz um discurso "subversivo" exortando aos outros mendigos a refletirem sobre o fato de tendo a comida ali à mão, porque não podem comer?

530 Tradução: Velha: (...) Fale você, senhor governador,estamos esperando...

Mendigo Um: Quisera comer algo.

Mendigos: Bravo.

Velha: Sempre tão demagógico.

Mendigo Um: Deveríamos poder comer com gosto nas malditas orgias dos trinta. Porque não se pode comer? Pergunto eu, senhores? Por que estando aí a comida, temos fome? Em que consiste senhoras e senhores, este enigma? Quem o haverá de resolver? Tenho o estômago pregado na costela, temos uma fome de cão, a comida está à mão e não podemos estirar a mão. Que se nos dê de comer nas orgias dos trinta.

Começa a tossir.

Velha: Um dos melhores discursos de um dos melhores governadores numa das melhores orgias.

Mendigo Dois: Não é justo que haja sobras.

Mendigo Três e Anão: Não. Não é justo.

Velha: Até excita as massas.

Anão: Cristo repartiu os pães e os peixes.

Mendigo Um e Dois: E o feijão e o campo.

Mendigo Um: Queremos os restos.

Mendigo Dois: Queremos os restos.

Anão: Queremos os restos.

Mendigo Três: Queremos os restos.

Todos os mendigos: Queremos os restos. Queremos tudo.

Mendigo Um: (Destapando a panela). Todo.

Velha: Alto aí. Reparto a comida quando me der vontade.

Agarra a panela.

Mendigo Dois: Solta a panela.

Mendigo Três: Velha avara.

Velha (lutando) Brutos. Vocês são uma porcaria. Retirem-se.

Por um instante os Mendigos retrocedem. O anão fica atrás dela e trata de alcançar a panela com o báculo. A velha pega a faca. $O$ anão retrocede.

Vocês são a escória, a merda. Vocês não são meus cavaleiros. Só abusam de uma velha desvalida que não tem mais que um filho mudo.

Mendigo Dois (Avançando): Acabou-se a comédia.

Mendigo Três: Velha louca. Velha louca.

Velha (Dando uma facada): Para atrás, corja de nojentos / hediondos.

Mendigo Um: Velha assassina. Feriu-me.feriu-me.

Mendigo Dois: Velha assassina.

Mendigo Três. Assassina.

Anão: Ajujiii. Viva a orgia.

Dando uma cajadada na cabeça da Velha, caindo esta para trás, sobre a mesa. Os mendigos caem sobre ela e a golpeam e apunhalam. Fica atravessada sobre a mesa. Sua cabeça caída, seus cabelos cinzas chegam ao solo. Em silencio, os Mendigos devoram a comida. 
Num primeiro momento, envolvido com a representação do tom de um discurso político como aquele de comício de praça popular, o Mendigo, confirma sua tarefa através da postura corporal, inclinando o corpo para trás. Mas uma contradição se encontra aqui. Embora o discurso seja em tom de comício, o conteúdo do discurso é de corte reivindicatório, que deveria estar na boca da massa e não de um político. Após esse pequeno choque, o Mendigo Um esquece o discurso do "governador" e começa a falar como o mendigo mesmo. Muda o tom da voz, o corpo se inclina para a frente e as mãos se crispam como se quisessem estrangular alguém, faz lembrar num átimo uma cena de um filme clássico do expressionismo alemão, o Gabinete do Doutor Caligari de Fritz Lang, ou ainda, Nosferatu F. W. Murnau.

Muitos elementos da estética do grotesco estão presentes na montagem, embora isso não possa ser suficiente para afirmar que Buenaventura tenha ido buscar diretamente em Meyerhold sua inspiração. Não há dados que confirmem isto. Mas o que pode ser afirmado é que esta obra do Nuevo Teatro, em particular, tem parentesco com muitas idéias estéticas reivindicadas por Meyerhold no contexto da vanguarda russa do início do século XX. Idéias que podem ser resumidas do seguinte modo: “confronto de contradições” no âmbito da linguagem e da encenação; “fusão de elementos opostos”, ou seja,

síntese dos contrários que essa 'deliberada exageração e reconstrução' artística fazem realçar, numa espécie de destilação sintética da própria ambivalência tragicômica da vida humana. Ao teatro, enquanto pura grostequerie, corresponde talvez a vida enquanto mascarada ${ }^{531}$.

Outra possibilidade de circularidade de influências indiretas e subterrâneas das escolas estéticas no curso do século XX pode ser localizada na vinculação entre Grotesco e Surrealismo que Wolfgang Kayser aponta. Mesmo que ele apareça de forma marginal no Surrealismo, sua presença foi suscitada pela leitura do pensamento de Freud empreendida pelos artistas do Surrealismo. Freud, como já se teve oportunidade de ver, foi referência importante para a formulação da sistematização do processo de criação teatral de Buenaventura.

E para além disso, é relevante lembrar que o Grotesco é uma escola estética que remonta ao século XVI e, ao que tudo indica, bastante apreciada pelos espanhóis

\footnotetext{
${ }^{531}$ Cavaliere, Arlete, 1996, p.97.
} 
(colonizadores da América Hispânica). Kayser faz um mapeamento do termo desde essa época, monstrando como ele está presente nas pinturas dos holandeses (colecionadas pela corte espanhola desde o século XVI) Hieronymus Bosch e Pieter Brueghel, o Velho, entre 1516 e 1569. Ou na pintura de Goya ${ }^{532}$. De acordo com este autor, a unanimidade da definição do conceito deve-se à repetição "dos primeiros intérpretes do grotesco no século XVIII, quando o termo veio se arrastando “como subclasse do cômico, ou mais precisamente, do cru, baixo, burlesco, ou então, do cômico de mau gosto”. Kayser considera que concretizações da estética grotesca realizam-se plenamente principalmente nas pinturas de Velásquez e Goya.

Muita coisa nas estampas de Goya é apenas caricatura, sátira, tendência amarga - mas tais categorias não bastam para a interpretação. Nessas gravuras escondem-se, ao mesmo tempo, um elemento lúgubre, noturno e abismal, diante do qual nos assustamos e nos sentimos atônitos, como se o chão nos fugisse debaixo dos pés $[\ldots]^{533}$.

A imagem poética da peça La Orgía emerge justamente da dualidade do jogo da peça. Do jogo de contradições e contrastes que acabam por desembor no Grotesco. Num plano da representação, deparamo-nos com a miséria concreta da realidade dos mendigos; noutro plano, no da encenação da festa dentro da peça, a representação de um ambiente, cuja sofisticação, alegria e leveza, deveriam ser evocadas. Daí a cena de Mendigo cheirando uma flor. Mas não há continuidade em nenhum dos planos. O tempo todo há fissuras, um palno invadindo o outro, o que impede a realização do sonho/lembrança da festa da prostitura de se realizar. O Mendigo chama de rosa a flor que cheira, sendo corrigido pela mendiga advertindo-lhe que se tratam de "fúcsias". O tempo todo ocorrem este tipo de cortes. Emerge algo de monstruoso na cena, que evocam imagens poéticas, sem no entanto deixar que a "beleza resvale para o plano do sentimentalismo fácil”534.

Afinal, "o horrível e o belo estão sempre contidos um no outro. Em todo o seu absurdo, este prodigioso paradoxo alimenta a própria vida, e, na arte, cria aquela unidade ao mesmo tempo harmônica e dramática”535, expressa na imagem poética. (p.42).

\footnotetext{
${ }^{532}$ Kayser, Wolfgang. O Grotesco. São Paulo, Perspectiva, 2003, p.14-16.

${ }^{533}$ Kayser, Wolfgang, 2003, p.15-16.

${ }^{534}$ Cavaliere, Arlete, 1996, p.92.

535 Tarkovski, A. Esculpir o tempo, p.42.
} 


\section{A Imagem Poética do LA CANDELÁRIA}

As propostas teatrais do grupo La Candelária tem alcançado nos últimos vinte anos uma assinatura própria. São produtos dos desdobramentos daquelas buscas originadas no seio dos inícios do Nuevo Teatro. Ao manterem a curiosidade e a vontade de se superar sempre em seus próprios resultados estéticos e políticos, o La Candelária conseguiu alçarse a elevadas alturas em seus vôos poéticos. Uma fome insaciável de saber incita os integrantes a uma contínua busca de informações, de leituras sobre a arte mundial, sobre a semiótica, cinema, estimulada por meio de oficinas de teatro, de dramaturgia, de trabalho de ator. Na década de oitenta, os próprios atores começaram a escrever peças teatrais, o que não é muito comum. As atividades intensas do grupo atendendo às demandas que a instituição La Candelária exige não impediram o prosseguimento em suas buscas estéticas. O resultado é a qualidade dessas últimas obras que o grupo oferece ao espectador. Para ilustrar isso, tomar-se-á para análise duas montagens: El Paso de 1988, e En la Raya de 1993. Comecemos com El Paso.

El Paso pode ser considerada a mais cinematográfica das obras do grupo, em cujo processo de criação foram exploradas, além de suas clássicas improvisações, as linguagens não-verbais, a estética minimalista, e princípio do cinema. A primeira cena, por exemplo, é totalmente baseada numa cena do filme Katzelmacher (1969) de Rainer Werner Fassbinder ${ }^{536}$, segundo fala de Santiago García ${ }^{537}$. Mas, antes de prosseguir, evoque-se aqui o contexto da montagem da peça e sua fábula.

\section{EI Paso}

1. Contexto da montagem da obra: El paso (Parábola del camino) representa a retomada da criação coletiva como método de trabalho depois de uma temporada de nove anos de recesso, período em que foram produzidas peças escritas e dirigidas por atores do grupo. Com relação a El Paso, Santiago García conta que tudo começou com a necessidade

\footnotetext{
${ }^{536}$ Cineasta alemão (1945-1982). Entre seus mais famosos filmes constam O casamento de Maria de Brown (1979), e Berlin Alexanderplatz (1980, série para tv).

${ }^{537}$ Duque Mesa, F.; Prada Prada, J., 2004, p.425.
} 
que sentiam de fazer um trabalho sobre o político revolucionário nicaragüense César Augusto Sandino ${ }^{538}$, no estilo da peça Guadalupe, años sin cuenta. Mas, que, ao perceberem que estavam repetindo uma fórmula, confessa Santiago García, não hesitaram em abandoná-la depois de quase um ano de trabalho. A partir de então, foram iniciadas novas improvisações, novas referências e buscas, quando se depararam com um conto de Bertolt Brecht, “Medidas contra a violência”, publicado em Histórias do Senhor Keuner. Deste conto surgiu a idéia da história de uma estalagem no meio de um caminho, numa encruzilhada, com personagens, cuja carcterística era a solidão e o isolamento. Em seguida a esta apresentação do lugar e dos seres, dá-se a "a invasão deste espaço perdido por um grupo de pessoas vindas da cidade. [...] O giro que a obra deu foi sair de Sandino, sair de Guadalupe años sin Cuenta..., e entrar na cidade”539.

A obra alude à violência imperante na Colômbia. Como diz Santiago Garcia, a peça, criada em 1988, era para funcionar como um tipo de metáfora da situação do país, mas numa antevisão ou num átimo visionário, aquilo que era para ser uma metáfora, acabou por se tornar tristemente na realidade do país. Estão sugeridas na peça “a violência do narcotráfico, a insurgência armada, o fenômeno do paramilitarismo, as intimidações, contrabando de armas”. O país vive sob o regime do medo, das ameaças, dos exílios e os assassinatos estão na ordem do dia. Nas palavras de Duque Mesa e Prada Prada:

O silêncio ronda por todas as partes. A parábola, a metáfora, a alegoria, fazem-se mais urgentes, junto com as linguagens não verbais e uma estratégia estética como o minimalismo ${ }^{540}$ e a ralentização ${ }^{541}$, convertem-

\footnotetext{
${ }^{538}$ Político nicaragüense (Niquinohomo 1895 - Manágua 1934). “[...] Surgido no seio de grupos liberais, César Augusto Sandino radicalizou suas posições, abandonando o liberalismo. Em seguida, desencadeou uma guerra de guerrilhas, conseguindo a desocupação do território nacional pelas tropas dos Estados Unidos. Declarado opositor tanto à intervenção ianque quanto aos grupos liberais e conservadores, Sandino foi assassinado em 1934 pelo primeiro Somoza que permaneceu no poder durante grande parte do século XX. In: Enciclopédia contemporânea da América Latina e do Caribe, op. cit., p. 861.

${ }^{539}$ Duque Mesa, F.; Prada Prada, J. Santiago García: el teatro como coraje, op. cit., p.422.

${ }^{540} \mathrm{O}$ minimalismo foi uma escola estética originada no âmbito das artes plásticas, no contexto dos revolucionários anos 60. Aparentada com o suprematismo e o cubismo do início do século, isto é, com o pensamento articulado por Malevich ( Kasimir Severinovitch, pintor e escritor russo, Kiev 1878 - Leningrado 1935) e Mondrian ( Pieter Cornelius Mondriaan, pintor holandês, Amsterdan 1872- Nova Yok 1944) postula entre outros princípios, a de que "uma obra de arte deve ser completamente concebida pela mente antes de sua execução”. Comprometidos com a clareza, com o rigor conceitual, com a literalidade e com a simplicidade, “as suas obras do período maduro apresentam características estilísticas comuns: formas predominantemente retangulares e cúbicas, expurgadas de toda a metáfora e significado, igualdade das partes, repetição e superfícies neutras”. Com a consolidação da estética minimalista como uma das mais influentes em nosso tempo, não demorou muito para que ela surgisse na música e na dança, cujos expoentes são os nomes de
} 
se em um terreno fabuloso para dizer com maior eloqüência e inteligência tudo o que não se pode dizer, em um país rural sitiado pelo esquecimento, pela morte, pela desmemoria, pelo abandono, pela intimidação, pelo animalismo e o deslocamento ${ }^{542}$. [Grifo nosso]

\section{Fábula:}

Num tipo de pousada ou hospedaria, estalagem ou um hotel barato de beira de estrada, numa encruzilhada no interior do país, encontram-se os personagens da peça: Chela, a dona da hospedaria; Doris, sua filha; Emiro, seu amante; os músicos 1 e 2; e, Obdulio, o ajudante geral. Os personagens estão fechados em si mesmos, ou, dito de outra forma, ensimesmados. Como se ali o tempo tivesse parado, vivem sob os valores das comunidades rurais e das músicas do século XIX. O ambiente começa a mudar com a chegada de um grupo de pessoas vindas da cidade, que, devido ao enguiço do carro onde viajavam, são obrigadas a ficar na estalagem. São elas: a senhora pequeno-burguesa que, numa aventura, foge com o amante, o taxista e a prostituta. Chove e com isso não há possibilidade de se consertar o automóvel, obrigando-os a permanecer no local. Mas a situação fica ainda pior com a chegada de mais dois personagens: dois tipos, Estranho 1 e 2, que conseguem alterar todo o ambiente da pequena estalagem. Eles, representantes da corrupção que impera no mundo lá fora, serão os agentes da invasão no mundo fechado e parado no tempo em vivem os moradores da estalagem. Eles submeterão estes moradores e os corromperão através do dinheiro. Segundo Mercedes Jaramillo, "esta obra aponta a atitude da sociedade colombiana reprimida pelo terror e pela violência”543.

\section{As seqüências selecionadas}

A) Montagem: El Paso (La parábola del camino), é a imagem da atitude de uma sociedade assolada pelo medo, terror e violência. É uma montagem em que a tônica recai sobre as

Philip Glass, Steve Reich (música) e Ivonne Rainer (dança). Nessas modalidades, o minimalismo se manifesta em composições de estrutura modular: música e dança baseada na repetição de elementos mínimos e na mudança gradual de pequenos motivos aolonfo de diferentes fases.In: Conceitos da arte moderna, op. cit., pp. 174-181.

${ }^{541}$ Do fr. Ralenti: tornar mais lento o movimento de algo. In: Dicinário Eletrônico do Houaiss.

${ }^{542}$ Duque Mesa, F.; Prada Prada, J. Santiago García: el teatro como coraje, op. cit., p.44.

${ }^{543}$ Mercedes Jaramillo, “La autonomia cultural en el teatro colombiano”, p.6. 
linguagens não-verbais, sobre a “cinese, a proxemia, o pequeno gesto e os indícios”" acordo com García. A partir da representação de vários fragmentos da realidade destes personagens, de forma poeticamente elaborada, daquele modo como sugere Eisenstein, tem-se à frente gradativamente a construção de uma imagem da violência e da solidão em que estãos emersos os cidadãos colombianos e latino-americanos.

A montagem tem 1h30m de duração. Foram selecionadas certas seqüências, com duração total de 31:29s, para ilustração do que aqui se pretende denominar imagem poética. Os recortes feitos da totalidade do filme de teatro pretendem ser demonstrações concretas dos argumentos que se defendem neste trabalho, sem perder de vista que o filme, é uma outra linguagem, distinta da teatral, e que por isso mesmo, ele pode tentar e até se aproximar daquilo que se chama a essência do teatro, mas jamais substituí-la. Mas não se pode negar que o filme de teatro foi um grande apoio na elaboração desse trabalho.

As seqüências selecionadas apresentam alto grau de elaboração estética em suas imagens, entretanto, é importante ter em conta que a imagem poética da montagem emerge como totalidade única ao cabo do espetáculo inteiro. É construída, pois, a partir dessa totalidade mesma do espetáculo. Entretanto, pode-se detectar uma pulsação entre imagens mais e menos fortes poeticamente, cuja costura em múltiplas direções cria relações também múltiplas no interior da peça, ou seja, nas imagens internas da peça. As imagens criadas no palco se oferecem aos sentidos e à percepção do espectador como um enigma e como revelação. A dialética entre a percepção do espectador e a imagem criada na cena, ao fim e ao cabo, é processo por meio do qual é produzida a imagem teatral e poética.

A seqüência de El Paso reproduzida no DVD que acompanha este estudo tem a duração total de: 31:29. É bom lembrar que a peça foi criada por meio da criação coletiva e da improvisação; o texto, portanto, surgiu do trabalho coletivo dos atores, diretor e demais profissionais. Santiago Garcia enfatiza o interesse em manter nessa montagem um certo ar de improvisação. Em razão de ser um produto de improvisações ligado ao fato de se direcionar na exploração de linguagens não-verbais, é perceptível nesse texto teatral um aumento considerável da parte dedicada às didascálias. Reproduz-se trecho do texto

\footnotetext{
${ }^{544}$ Duque Mesa, F.; Prada Prada, J. Santiago García: el teatro como coraje, 2004, p.425.
} 
referente à abertura do espetáculo, apenas como referência, uma vez que o foco principal de análise é a encenação.

Seqüência 1: “Abertura da peça”- 0h01m00s a 0h07m52s. Exposição das personagens e da situação.

En la penumbra del escenario, una taberna o parador en un cruce de caminos, dos músicos con uma guitarra, Emiro saca cuentas. Don Blanco se reuesta contra el mostrador.

Los músicos esperan inmóbiles en un pequeno estrado. De pronto empiezan a tocar uma canción: "poe el camino verde".

Don Blanco cabecea amanecido.

Emiro, a la luz de una vela, continúa sacando cuentas.

Del fondo, arreglándose el pelo, aparece Chela. Llega hasta el proscenio.

Mira detenidamente al cielo.

Amanece.

Empieza a gotear. Estira la mano para constatar la lluvia.

Da uma vuelta por la taberna hasta llegar al mostrador.

Don Blanco se hace servir dos tragos.

Termina la canción.

Don Blanco se acerca com los tragos a los músicos.

Los músicos beben.

Chela se arrima a Emiro y le pregunta.

CHELA

Qué hubo? Encontró los quinientos pesos?

Emiro sigue examinando las cuentas sin hacerle caso. De pronto

empieza furiosamente a rayar el papel y se para refunfuñando.

Entre violentamente al fondo, a lo que podría ser la trastienda, y desde

allá lanza impropérios y exclamaciones.

Se oyen puertas y cajones que se golpean.

Sale con unos vestidos y unas camisas.

Sigue refunfuñando lleno de ira.

Lo que dice entre dientes prodría ser:

\section{EMIRO}

"Ya no más! Si quiere las cuentas tan claras, tan claras, pues que las saque ella misma. A joderse en otro! Eso le pasa a uno por pendejo! Toda la noche trabajando como un burro para qué! Yo también tengo mi dignidad! Si piensa que soy un ratero que se busque otro marrano! A otro perro con esse hueso! Eso le pasa a uno por vivir así amancebado! Esta ilegalidad en la vida es la que lleva a eso! A que le falten al respeto a uno! No más y no más!! Yo me largo de aqui!!”

Entra y sale repetidas veces de la trastienda. Saca una maleta de cuero y mete precipitadamente los vestidos en ella.

Cada vez que entra a la trastienda eleva más la voz y grita insistemente: "Doris, la revista que le presté". Continúa maldiciendo y se devuelve varias veces por algo que cree haber olvidado".

\section{EMIRO}


Cinco años en esta carajada y qué es lo que he sacado? (imitando a Chela) "Qué hubo, encontró los quinientos pesos?”. Cara de buen pendejo fue la que me vió!! No más, me largo ya!”.

Se devuelve otra vez y regresa con unas revistas.

Abre la maleta y las guarda. Cierra la maleta. Se dispone a salir. Cuando va saliendo Chela lê habla desde la posición en que se ha mantenido desde el comienzo de la rabieta de Emiro.

\section{CHELA}

Usted puede largarse de aqui cuando quiera, pero no con mi maleta de cuero. Esa, me la deja aqui.

Emiro se voltea y le arroja la maleta a los pies.

Luego entra precipitamente a la trastienda.

Se oyen de nuevo cajones y puertas.

Grita e lanza denuestos.

Sale con un talego de plástico.

Abre la maleta. Saca las cosas y las mete en el talego.

Le entrega la maleta a Chela.

\section{EMIRO}

Ahí la tiene, su maleta!

Sale Doris con la revista y se la entrega a Emiro.

Emiro toma la revista y la guarda en el talego. Se devuelve y saca un sombrero y se lo pone.

Empieza a llover.

Del fondo aparece Obdulio a medio despertar.

Emiro avanza hasta el proscenio pero se detiene por la lluvia.

Don Blanco se acerca de él mira el cielo y le dice:

\section{DON BLANCO}

Para dónde se quiere ir si por aquí ya no pasa ningún carro. Usted más que nadie sabe que de aqui con este tiempo uno no se puede largar.

Emiro se queda frenado en el proscenio y sigue murmurando algo así:

\section{EMIRO}

Puta que lo parió. Lo único que me falta es que trague el mismo putas! Que me trague y me lleve a los profundos infiernos!!

De pronto suena una música operática a todo volumen. Emiro sigue murmurando pero la música no deja oír todo lo que dice.

\section{EMIRO}

Algún día toda la lluvia del mundo ha de inundar este puto lugar!! Recontra chucha de vida que en vez de agua debería caer uma tonelada de mierda que lo sepultara todo! Rios de podredumbre el día en que yo pus elos ojos en esa mujer que ha sido mi perdición!! Que caiga un rayo que nos carbonice a todos los que vivimos metidos hasta el cuello en este horrible pecado de estar aqui!!

En medio de la música operática y mientras Emiro lanza sus maldiciones entra un tropel de gente al parador. Son quatro personas. Vienen cubriéndose con un plástico grande y uma sombrilla.

Se sacuden y limpian sus ropas.

Son: el chofer de un táxi intermunicipal, un joven y una señora muy elegante y una prostituta.

El taxista saluda a todos y se dirige a Emiro.

Le habla para explicarle lo que les pasó.

Chela invita a la pareja para que sigan. 
Ordena a Doris para que atienda a los pasajeros.

Lhama a Obdulio.

Le quita el talego e plástico de las manos a Emiro, que estaba parado en la mitad sin saber qué hacer.

Doris prepara las mesas y los asientos.

Obdulio sale y con tun trapo limpia las mesas.

La pareja se pasea por el recinto examinando los puestos.

El taxista lê explica a Emiro lo que les pasó: "Como a un kilômetro de ahí el carro le patino y se lê fué de lado, después ya no quizo arrancar.

Fueron las balineras que se lê rompieron al eje de la rueda de atrás.

Tendrá que esperar que alguien le traiga los repuestos”.

Emiro le dice que por lo que le está contando él no cree que sean las

balineras, que le parece que más bien ha de ser el cardán, lo cual es

menos problemático.

El taxista le muestra unas piezas que tiene en la mano y le asegura que son las balineras.

Emiro le dice que va a consultar su revista.

La pareja de amantes al fin se decide por una mesa del extremo y

comienza a limpiar el puesto.

Cesa la música operática.

(...)

Pausa larga. Cada uno se acomoda en su puesto y está en pensamientos.

Chela dicta una carta a Doris.

CHELA

...aquí no pasa nada...o mejor dicho menos que nada... de fuera llegan noticias...son cada día peores...en Torrentes por exemplo la semana pasada mataron otros seis hombres...(.... $)^{545}$.

\footnotetext{
${ }^{545}$ Na penumbra do cenário, uma taverna ou estalagem numa encruzilhada, dois músicos com um violão. Emiro confere as contas. Don Blanco está enconstado ao balcão.

Os músicos esperam imóveis num pequeno palco/tablado. De repente, começam a tocar uma canção: "por el camino verde".

Don Blanco começa a se mexer.

Emiro, à luz de uma vela, continua conferindo as contas da estalagem.

Do fundo, arrumando o cabelo, aparece Chela.

Chega até o proscênio.

Olha detidamente para o céu.

Amanhece.

Começa a gotejar. Estica a mão para constatar a chuva.

Dá uma volta pela estalagem até chegar ao balcão.

Dom Blanco se serve de duas doses de bebida.

Termina a música.

Don Blanco se aproxima com as doses dos músicos.

Os músicos bebem.

Chela se aproxima de Emiro e pergunta.

CHELA

Que houve? Encontrou os quinhentos reais?

Emiro continua a examinar as contas sem responder.

De repente, começa furiosamente a rabiscar o papel e para resmungando.

EMIRO
} 
Entra violentamente ao fundo, ao que poderia ser um quarto atrás da estalagem, e desde lá lança impropérios e exclamações. Ouvem-se bater e golpes de portas e caixas. Sai com umas roupas e umas camisas.

Continua resmungando cheio de raiva.

O que diz entre os dentes poderia ser:

EMIRO

“Já não mais! Basta! Se quer as contas tão claras, tão claras, pois que você as faça então por si mesma. Vai encher o saco de outro. Vai se foder com outro. Isso acontece a uma pessoa por causa da dependência. Toda noite trabalhando como um burro para qué! Eu também tenho minha dignidade. Se pensa que sou um ladrão que busque outro porco. A outro cachorro com esse osso. Isso acontece a um homem por que vive amigado/amasiado. Esta ilegalidade na vida é o que leva a isso! A que te faltem com o respeito!!Não mai, não mais! Vou me embora daqui!!”

Entra e sai repetidas vezes do quarto de trás. Pega uma maleta de couro e mete precipitadamente a roupa nela.

Cada vez que entra no quarto eleva mais a voz e grita insistentemente: "Doris, a revista que te emprestei". Continua xingando e se volta várias vezes por alguma coisa que pensa ter esquecido.

EMIRO

Cinco anos neste caralho e o que é que eu ganhei? (Imitando a Chela) "Que houve? Enocntrou os quinhentos reais? Cara de um idiota foi a que me viu! Não mais, vou me mandar já!”.

Entra no quarto outra vez e volta com umas revistas.

Abre a mala e as guarda.

Fecha a mala.

Dispõe-se a sair.

Quando vai saindo Chela lhe fala da posição em que se manteve desde o começo da raiveta de Emiro.

CHELA

Você pode se mandar daqui quando quiser, mas não com a minha mala de couro. Essa, fica aqui.

Emiro volta-se e lança a mala aos pés.

Então entra precipitadamente no quarto dos fundos.

Ouve-se de novo caixas e portas.

Grita e lança insultos.

Sai com um saco de plástico.

Abre a mala. Tira as coisas e as joga no saco.

Entrega a mala a Chela.

EMIRO

Aí tens sua mala!

Sai Doris com a revista e a entrega a Emiro.

Emiro pega a revista e a guarda no saco. Volta-se e pega um chapéu e o coloca.

Começa a chover.

Do fundo aparece Obdulio, despertando-se aos poucos.

Emiro avança até o proscênio mas se detém por causa da chuva.

Don Blanco se aproxima dele, olha para o céu e diz:

DON BLANCO

Para onde se quiser ir por aqui já não passa nenhum carro. Você mais que ninguém saber que daqui com este tempo ninguém pode se mandar.

Emiro fica parado no proscênio e continua murmurando algo assim:

\section{EMIRO}

Puta que pariu. O único que me falta é que tolere ele mesmo putas! Que me trague e me leve aos infernos profundos!!!

De pronto soa uma música operática a todo volume. Emiro continua murmurando mas a música não deixa ouvir tudo o que diz.

EMIRO

Algum dia toda a chuva do mundo há de inundar este puto lugar!! Reencontra um tipo de vida que em vez de água deveria cair uma tonelada de merda que o sepultasse todo! Rios de podridão que arrasarão este moridero! Maldito e contramaldito o dá em que eu pus os olhos nessa mulher que tem sido minha perdição!! 
Que caia um raio que nos carbonize a todos os que vivimos metidos até o pescoço neste horrível pecado de estar aqui!!

Em meio da música operática e enquanto Emiro lança suas maldições entra um grupo de gente à estalagem. São quatro pessoas. Vêm sobrindo-se com um plástico grande e uma sombrinha.

Sacodem-se e limpam suas roupas. São o chofer de um táxi intermunicipal, um jovem e uma senhora muito elegante e um aprostituta.

O taxista saúda a todos e se dirige a Emiro.

Fala-lhe para explicar-lhe o que lhes aconteceu.

Chela convida o casal para que entrem.

Ordena a Dorus para que atenda aos passageiros.

Chama Obdulio.

Toma o saco de plástico das mãos de Emiro, que estava parado na metade sem saber o que fazer.

Doris prepara as mesas e os assentos.

Obdulio sai e com um trapo limpa as mesas.

O casal passea pelo recinto examinando os postos. O taxista explica a Emiro o que lhes aconteceu: "Como a um quilômetro dali o carro patinou e escorregou para o lado, depois já não quis arrancar. Foram as "balineras" que romperam-se no eixo da roda de trás. Terá que esperar que alguém lhe traga as reposições".

Emiro lhe diz que pelo que ele lhe está contando, ele não crê que sejam as "balineras", que lhe parece que há de ser o "cardán”, que é menos problemático.

O taxista mostra a ele umas peças que tem na mão e o assegura que são as balineras.

Emrio diz a ele que vai consultar a sua revista.

O casal de amantes ao fim se decidem por uma mesa do canto extremo e começam a limpar o lugar.

Para a música operática.

Pausa longa. Cada um se acomoda em seu lugar e estão em pensamentos.

Chela dita uma carta a Doris.

CHELA

...aqui não acontece nada... ou melhor dito menos que nada... de fora chegam notícias ....são cada dia piores...em torrentes por exmeplo a semana passada mataram outros seis homens... (...) 
Do ponto de vista do espectador, a primeira imagem dada a ver são os dois músicos, que num tablado à direita do palco, tocam e cantam uma antiga canção colombiana. Trata-se de uma música melancólica, mas envolvente. Pela caracterização dos músicos, fica-se sabendo que se trata de pessoas advindas do meio rural, mas caracterizados num leve tom cômico. O correlato no Brasil seriam as duplas sertanejas de raiz, mas também valeria para a música sertaneja brega.

Há circularidades infinitas no espetáculo que podem ser detectadas desde o início. A canção se chama "Camino Verde” e é evidente a sua localização no mundo do campo, onde ainda se encontram "caminhos verdes”; mas mais que isso, refere-se a um “caminho”, que também vem no subtítulo da peça (parábola del camino); apontando assim duplamente para o espaço cênico ${ }^{546}$ : uma estalagem pobre, perdida numa encruzilhada de “caminhos".

\footnotetext{
${ }^{546}$ Espaço em que, além de cenário e objetos, é fabricado essencialmente pela gestualidade e pela phoné dos atores. In: Ubersfeld, Anne. Ler o teatro, p.110.
} 
Como se verá depois, este entrecruzamento geográfico espelha de certo modo o entrecruzamento de pessoas, cada uma delas na sua própria encruzilhada da vida.

Até a metade da música, a luz está fechada nos músicos. O foco vai abrindo lentamente, iluminando os outros espaços, quando então se depara com um homem sentado na mesa, debruçado sobre algo; ao mesmo tempo, avança também lentamente do fundo para o procênio, uma mulher prendendo os cabelos. A montagem de sua gestualidade é rica em signos e remete a detalhes significativos como operação de reconhecimento do universo da personagem, como, por exemplo, seus gestos de prender os cabelos. Há um momento em que pega um grampo que está preso na borda do vestido que está usando, um gesto simples, mas bastante difundido entre as mulheres de grupos populares, e imediatamente reconhecível. Chove. Sabe-se disso por meio do som. Mas também por gestos que o confirmarão. Chela (o nome da mulher) pára no procêsnio, termina de prender os cabelos, estende o braço para ver a densidade da chuva, enxuga a mão molhada na roupa, mira o horizonte para a direita e depois para a esquerda; e finalmente, vira-se em direção ao alcão do bar no fundo à esquerda do palco. Tudo muito devagar. Enquanto ela está na frente do palco, a luz abre mais e torna-se mais forte, vê-se então de costa para o público, próximo ao balcão, Don Blanco, um fazendeiro das redondezas. É o dia que amanhece e com ele as pessoas lentamente começam a se entregar aos seus afazeres cotidianos. Chela vai ao balcão no fundo da estalagem ou taverna, e atende a Don Blanco que pede duas doses. A música está chegando ao fim, quando acaba, o dia já amanheceu e don Blanco leva a eles as duas doses de bebida.

Chela se aproxima de Emiro, o homem que desde o início está debruçado sobre a mesa. Ela pergunta a ele se encontrou os quinhentos pesos. Pausa. O homem pára de escrever ou de conferir as contas. Não a olha. De estático num momento, explode num arroubo de raiva. Começa a resmungar impropérios a Chela, ao mesmo tempo, rabisca o caderno que examinava e o lança sobre o balcão; desaparece momentaneamente no fundo, entrando na coxia, o que deveria ser um quarto dos fundos da taverna. Ouve-se lá de trás pancadas e seus resmungos; volta com um punhado de roupas e a joga sobre a mesa; volta ao fundo e trás uma mala de couro. Nervoso, joga tudo de qualquer jeito dentro da mala, resmungando e xingando sempre. Pede repetidas vezes que Doris lhe devolva sua revista. Quando apronta a mala e vai se retirar, Chela o detém, dizendo que ele pode ir se quiser, mas tem de deixar 
a mala que é dela. Ele fica ainda mais raivoso, joga a mala aos pés de Chela, vai em busca de alguma coisa e volta com um saco de plástico, onde enfia seus trapos. Põe o chapéu na cabeça e quando se prepara para ir, entra Doris e lhe estende a revista. Pausa. Ele arranca a revista, enfia no saco, diz adeus e se dirige para o proscênio. Detém-se na frente. Está chovendo. Então ele continua com um discurso quase inaudível para a platéia, mas sua expressão facial mostra o desespero, a raiva e a angústia do homem. Nisso, don Blanco se aproxima dele, aconselhando que não dá para ir a lugar algum com esta chuva. Começa a se ouvir uma música operática que não suprime totalmente mas deixas as vozes ainda mais longíquas.

Neste ponto, há claramente um corte. O espaço cênico horizontal, os personagens encerrados nele e aquele mundo habitado por aquela gente acabaram de ser apresentandos ao público. A música que entra agora não é do ponto de vista interno da cena, não são os músicos que a executam. Essa música é extra-cênica e é claramente uma opção do encenador; é uma interrupção da linha contínua de ação da cena. O efeito da entrada dessa música, nesse momento, é claramente cinematográfica. Como se, depois de mostrar de perto, em primeiro plano, um certo conflito, a câmera num longo plano-seqüência fosse se distanciando do foco do conflito, ampliando o horizonte, trazendo para dentro do plano tudo o que povoa o contorno do conflito central mostrado em primeiríssimo plano.

Se fosse cinema, a câmera teria se distanciado do drama particular de Emiro, de sua raiva e humilhação, para mostrar o lado de fora da estalagem, a localização dela numa encruzilhada e nesse movimento, mostraria ao espectador que umas quatro pessoas, tentando se proteger da chuva, vão em direção à estalagem. Mostraria além disso o carro a certa distância parado na beira da estrada. Mas estamos no teatro, seus recursos são outros. De qualquer forma, esta música operática e incidental mostra a distância entre o drama de Emiro e o mundo lá fora. Interrompe e anuncia um novo acontecimento. A recorrência dessa mesma música incidental, inclusive, marca sempre uma modificação na situação, anunciando uma ocorrência nova na cena.

Em seguida a entrada da música, entram na cena quatro personagens meio molhados sob uma grande capa de plástico: um motorista de táxi, uma prostituta e um casal de amantes. Estavam viajando de Denges para Rivalta e o carro quebrou, o público saberá maisz tarde. Em seguida, cada um será acomodado numa das mesas da taverna. Em seguida estes 
persoangens começarão a criar relações, mútuas desconfianças, preconceitos, disputas, tudo quase que por meio de olhares, gestos e etc.

Essa grande descrição a partir do ponto de vista do espectador mostra o jogo de cena, cuja rede de códigos vai progressivamente construindo uma imagem da vida dessa gente e seus medos. É-se tomado de grande empatia por tais personagens, porque se crê neles. Em sua pequeneza, são sinceros e comoventes. Nicolas Buenaventura diz que vê nessa estalagem uma daquelas posadas espaçosas, onde se poderia chegar de carro ou à cavalo e se acomodar confortavelmente. Que certamente teve seu esplendor num tempo, quando Rivalta fora um povo próspero, antes do apodrecimento a que a violência lhe impusera, fazendo com que muita gente deixasse a cidade ${ }^{547}$.

A trama de cada um dos personagens pode ser resumida assim: o casal de amantes estão viajando incógnitos; tudo corria bem na viagem, mas quando o carro quebra e eles têm de ficar ali, eles começam a se desentender. Ao final da peça, estão claramente separados, ela não quer nem que ele a toque mais. Diz-lhe que quer voltar para seu marido e filhos. A prostituta teve de sair de Rivalta por falta de trabalho, mas vai regularmente à cidade levar dinheiro para sua família. Sobre Don Blanco, o estancieiro, Nicolas Buenaventura levanta muitas suspeitas: “na trama, há um nó. (...) trata-se precisamente da fazenda de don Blanco. Quem ampara esta fazenda? Quem a assegura?”. Ele, com tanta terra, não poderia ter sobrevivido sozinho em uma zona de guerra. Nicolas sugere que ele seja um tipo daqueles que se desliza fácil para o lado da corrente: seria o que negocia com os guerrilheiros. Outro fio da trama refere-se ao destino do armamento: vai para a guerrilha? "Vai para guerrilha, paga com pasta de coca?” Ou vai para grupos paramilitares. O “Homem de negro” e o helicóptero não deixam dúvida de que se trata de ordem “de cima”, e bem de cima.

Nicolas Buenaventura observa que "os personagens não existem senão como expressão ou resultado de suas relações humanas” ${ }^{, 48}$. Na abertura da peça, como descrita acima, com a partida frustrada de Emiro, é revelado todo o conflito da obra: “a infinita solidão que amarra para sempre o grupo. Toda a miséria que sustenta essa solidão e que cabe numa bolsa de plástico" ${ }^{\text {549 }}$. A partir das relações entre eles, o espectador começa se dar conta de

\footnotetext{
${ }^{547}$ Buenaventura, Nicolas. “El Paso”. In: Revista del Teatro La Candelária, no. 4, janeiro de 1990, p.5.

${ }^{548}$ Buenaventura, Nicolas, 1990, p.5.

549 Buenaventura, Nicolas, 1990, p.6.
} 
quem são aqueles personagens a sua frente. Assim, aos poucos desvenda-se a situação de Emiro. Embora sem dinheiro, era o único culto do lugar, que lia jornais e revistas. Quando o marido de Chela foi assassinado, pensou que iria substituí-lo em tudo e se tornaria "el señor” do lugar, mas logo Chela tomou o lugar do marido no comando da pousada e colocou Emiro em seu devido lugar, isto é, não passava de um amancebado.

“Toda a dinâmica de El Paso está em função deste tema (...): “a comunidade se nega a morrer. Ela mesma se refaz, reagrupa-se uma e outra vez quando os golpes da violência a estão desintegrando" 550 . Nesse sentido, Nicolas identifica "quatro situações com o mesmo signo: 1. a reorganização familiar da posada, depois da morte do marido de Chela; 2. a chegada dos forasteiros, das pessoas da cidade que gera uma alteração no ambiente; 3. quando a comunidade já se reorganizou outra vez, um novo conflito se precipita com a entrada em cena dos estranhos; e, 4. O assassinato do cachorro e do fazendeiro.

Seqüência 2: Longa pausa. "Chela dita carta”. 0h07m55s a 0h09m06s.

As pausas são outro recursos recorrentes ao longo da representação. Pode significar muitas coisas. O silêncio instaurado um tempo após a chegada das quatro pessoas da cidade pode indicar o reacomodamento da situação no espaço, integrando o novo elemento. Cada um no seu lugar, dobra-se sobre seus próprios pensamentos. Ninguém pode sair daquele lugar; de certo modo, é uma resignação a um estado de coisas ou a instauração na comunidade do sentimento de impotência. Após longa pausa, Chela, a dona da pousada, começa a ditar uma carta que escreve a um parente. O ditado desta carta escrita por Doris será outro evento recorrente como as pausas e a música incidental, sempre para marcar um grau de mudança na situação. Neste momento, é o primeiro momento do ditado da carta, quando então ficase sabendo da violência ao redor, e “aqui no pasa nada”. Segundo Nicolas, é um modo de a família se apresentar aos recém-chegados.

Seqüência 3: “Os músicos tocam outra música a pedido de Don Blanco”. Chegada dos dois estranhos. 0h09m08s a 0h17m19s.

${ }^{550}$ Buenaventura, Nicolas, 1990, p.7. 
Segundo Nicolas, a chegada dos estranhos 1 e 2 dá origem a uma nova situação, a “dinâmica interior da obra (refazer uma e outra vez a comunidade), requer uma força extraordinária. O grupo foi desfeito e é preciso reconstruí-lo outra vez”551. Praticamente todos tentam abordar aos estranhos. O primeiro deles, Don Blanco, em “ofensiva para a comunicação”, que se apresenta como fazendeiro, “com muito respeito”, “minha fazenda é a única que tem 'gua aqui”. O amante é o segundo deles, sem conseguir coisa alguma da dupla de estranhos. Depois é a vez de Emiro que chega com sua revista "mecânica automotiz”. Mas todos se estilhaçam contra um muro inquebrantável. Essa seqüência da cena foi construída de modo que se torna um mote cômico a situação gerada pelos estranhos. É tão impensável para a comunidade a atitude de recusa de comunicação dos estranhos que quando as três pessoas da pousada se deparam com ela, o estranhamento suscitado neles, provoca o riso do espectador. Assistir a don Blanco se afastando de costas repetindo três vezes "com mucho respecto”; ou o amante, sem jeito, começando a repetir o mesmo texto, vai reforçando o ridículo da situação. Mas a comunidade não desiste e para que ela se refaça é preciso estabelecer contato com estes novos comapnheiros de slidão. Então é que Obdulio consegue romper a muralha ao trazer a mala esquecida no banheiro por um dos estranhos.

Seqüência 4: Longa Pausa. Don Blanco fica entalado. Saída dos estranhos. 0h17m21s a 0h18m50s.

Após três tentativas frustradas de comunicação com a "parede" representada pelos dois estranhos, dá-se outra longa pausa. É interrompida bruscamente pela entaladela de Don Blanco, que, ao se engasgar com a comida, começa a ficar sem respirar. Passa por apuros e é socorrido por todos da pousada. Menos os dois estranhos, cuja impassibilidade faz com que continuem sentados em sua mesa. Na seqüência, tiros lá fora são ouvidos. Isso provoca nova inquietação em todos; os estranhos têm um movimento de sobressalto, e o grupo que socorria Don Blanco instantaneamente se dispersa, juntando-se no fundo à extrema direita do palco, de onde vieram os sons de tiros.

\footnotetext{
${ }^{551}$ Buenaventura, Nicolas, 1990, p.8.
} 
Seqüência 5: Músico entrega carta a Dóris, que ao lê-la, dá uma gargalhada. 0h18m59s a 0h20m08s. Após nova tentativa frustrada de fuga, desta vez de Doris, que esperava ir-se embora com os estranhos, passa-se a seguinte cena: a declaração de amor do músico dois a Doris. Cena patética. Há todo um jogo corporal. Silêncio. Doris está sentada desconsolada à mesa, o músico se aproxima com timidez, vem com uma carta e uma rosa na mão para oferecer a Doris. Ela não o percebe. Ele fica um tempo atrás dela com seus presentes na mão sem sequer ser notado. Cada vez mais sem jeito, o que mostra pelo gesto reiterativo de levar a mão ao cinto da calça para arrumá-lo, aproxima-se mais e deposita sobre a mesa à frente da moça. A moça olha, pega a carta, abre-a e começa a ler. Após a leitura, olha para o músico e solta histericamente uma gargalhada. O músico fica mais desconcertado. Ela para de rir, volta-se séria e mira o horizonte, também num gesto reiterativo de enfado, apóia o cotovelo sobre a mesa e a cabeça na mão. Nicolas observa agudamente que há algo mais nessa gargalhada de Doris. Há medo. “O riso funciona com uma espécie de exorcismo para afugentar os presságios. Sobre a sombra da mãe viúva e amancebada, sente que os destinos das duas estão se cruzando" ${ }^{552}$. No final, Doris se recusa a se ir com um dos estranhos que, tendo de voltar para a pousada, dessa vez, tenta levá-la com ele. A recusa vem depois de revelada a violência dos estranhos: eles matam o cão e Don Blanco.

Seqüência 6: Estranho 2 mata cachorro e estranho 1 oferece dinheiro como reparo. 0h20m09s a 0h23m46s.

Nessa cena, dois eventos importantes. A cena em que eles atiram no cachorro e a corrupção das pessoas da pousada. A cena da morte dos cachorros parece ter sua inspiração também no cinema. Há um filme colombiano, chamado “Condores no entierran todos los dias”, que retrata a disputa entre os conservadores e os liberais durante "os anos da violência",553, entre 1948 e 1958, numa cidadezinha do interior. Esse filme mostra como "um modesto empregado e católico fervoroso”554, León Maria Lozano, pode se transformar num assassino violento, cumprindo um papel macabro durante os anos da violência. Nesse filme,

\footnotetext{
552 Buenaventura, Nicolas, 1990, p.6.

${ }^{553}$ Santiago García e Francisco Martínez atuam nesse filme. Diretor do filme: Francisco Norden, de 1984.

554 Texto da cantra-capa do DVD do filme.
} 
há uma cena semelhante. Quando Lozano tenta redigir uma carta (numa espécie de quartel general), intimando um liberal a deixar a cidade, de repente os cachorros começam a ladrar lá fora incessantemente, quando então Lozano ordena a um dos seus subordinados que los matem. O enquadramento no filme não muda, ouve-se apenas os tiros lá fora e o cessamento dos ladridos. Ao atirar em animais, consegue-se revelar a dimensão da brutalidade da violência de forma muito mais cabal e chocante.

Este mesmo efeito é conseguido na peça. Quando Obdulio volta sem conseguir fazer com o cachorro pare de latir, imediatamente, um dos estranhos sai, acompanhado de novo por Obdulio, e atira no animal. Essa cena provoca uma verdadeira revolta na pousada. Chela reclama sem parar a morte do animal, “me mataram el animalito”. Nessa seqüência, assistese o método que se utiliza para corromper estas pessoas. Estranho 1 oferece dinheiro para reparar um pouco a morte do animal e coloca sobre a mesa um maço de notas. Nesse momento, dá-se o discurso de Emiro que também é central para a compreensão da peça. Ele diz que este tipo de coisa acontece lá fora, não ali dentro de sua casa, mas aos poucos aproxima a mão e pega o dinheiro sobre a mesa. Quando ver o dinheiro na mão, fica calado esperando o que Chela poderá dizer. Ela fica furiosa, mas deixa que ele decida. A música operática já está em cena outra vez. Emiro avança para a frente do palco meio entorpecido com o dinheiro na mão, prepara-se para contá-lo não antes de fazer o sinal da cruz como se o benzesse e então o enfia no bolso.

Seqüência 7: Músico 1 descobre que nas caixas dos estranhos há armamento. Estranhos se irritam com esta descoberta. Há confusão. Estranhos matam Don Blanco. 0h23m48s a 0h27m06s.

Em seguida, o músico 1 descobre o produto das caixas que os estranhos pediram para guardar temporariamente na pousada. Trata-se de balas de munição, armamento pesado. Esta descoberta desencadeia outra tensão no grupo. O músico mostra a munição a Emiro, que chama Chela, para mostrá-la; esta, indignada, recorre a Don Blanco, que enfim vai tirar satisfações com os estranhos. Depois de uma série de ameaças, Don Blanco chama os dois homens para fora, o que vai acarretar a morte de Don Blanco. 
Seqüência 8: Revolta das pessoas pelo assassinato de Don Blanco. Tensão geral.

O assassinato de Don Blanco vai provocar um verdadeiro terror dentro da pousada. Todos ficam muito assustados. O Estranho aponta a arma e ameaça a todos. Diz que foi em legítima defesa. Nesse momento, chega o helicópetero, como o Homem de negro.

Com quem os estranhos fazem a transação do armamento. E diz a frase final que resume o espetáculo: “Aqui no há passado nada”. 0h27m ao final ( 0h31m28s).

\section{En la raya}

A novela, Crônica sobre uma morte anunciada, de Gabriel García Marques foi o ponto de partida do espetáculo. Conta Santiago García que se trata do resultado de uma série de improvisações feitas sobre o tema da novela. De posse destes materiais, fruto do trabalho de varios meses, passaram a encarar o segundo passo do processo:

Que consistiu em confrontá-lo ou opô-lo a uma situação social e a uma série de estudos sociológicos que se estavam fazendo sobre um dos problemas mais patéticos que padecem nossas grandes metrópoles terceiro mundistas: o aparecimento de um estrato social de marginais, conformados por gentes que vivem nas ruas e que autodominam "excluídos".

Santiago informa ainda, que vários integrantes do grupo estavam trabalhando num programa de reabilitação social destes grupos urbanos de drogados, de desadaptados, ou dos chamados excluídos. Apropriando-se da teoria de Rossi Landi, Santiago identifica essas situações da vida real destes grupos como NT (não teatro), segundo a definição que ele cita:

NT é uma negação determinada: um modo genérico de dizer que, frente ao teatro, existem situações sociais e políticas, condições humanas individuais e coletivas, maneiras comuns ou singulares de comunicar e representar, teorias filosóficas, técnicas de todo tipo, além da cena e o público, ou os dois, na medida em que não constituem, ou todavia não, aquela síntese particular que é o teatro. Todo este material não teatral pode ser utilizado para seus fins pelo homem de teatro, e isso ocorre muito freqüentemente; mas só se convertirá em teatro quando de algum modo resulte integrado a uma síntese entre palco e platéia”,555.

\footnotetext{
${ }^{555}$ Rossi Landi, citado por Santiago García na obra, Teoria e practica del teatro, vol. 2., p. 36.
} 
No terceiro estágio do processo de montagem da peça, ocorreu justamente essa síntese, de acordo com o relato de García:

Ao enfrentar dinamicamente estes dois materiais concluímos uma síntese, em que as propostas teatrais da novela se fundiram com a situação social dos "excluídos", dando como resultado um teatro dentro do teatro, que satisfazia tanto nossos interesses de caráter estético, como nossos requerimentos de caráter ideológico, consistentes em empenhar nossos esforços não só numa representação da realidade, senão que essa representação tivesse um significado denso de caráter conotativo. O regresso a uma sínteses teatral é o enriquecimento de significação da proposta de partida ou da tesis inicial.

E o resultado foi a criação de mais uma obra poética no repertório do Nuevo Teatro.

\section{Contexto da montagem da obra}

Segundo conta Santiago García, o pretexto da montagem de En la Raya surgiu com o pedido do Ministério da Cultura da Espanha para a celebração do Quinto Centenário da Conquista da América, em 1992, quando queriam ter oito obras da América Latina. Da Colômbia, escolheram Gabriel Garcia Marques, ao Teatro La Candelária e a ele, Santiago García. Foi aceito o projeto por todo o grupo. Entraram em contato com Garcia Marques, que o aceitou. Pensaram na novela do escritor colombiano, Morte de uma Crônica anunciada. Mas depois de dois ou três meses de ensaio, foi exigido pelo Ministério a autorização do autor. Ao fim de idas e vindas, negaram a autorização da obra e o La Candelária perdeu o contrato. Abandonaram o projeto e voltaram-se para o projeto que Patrizia Ariza e Rafael Giraldo estavam desenvolvendo com marginais e excluídos. Resolveram então juntar os dois projetos. Restaram algumas imagens do trabalho que começaram a fazer a "Crônica...”, assumindo assim a montagem numa versão muito livre da novela de Garcia Marques. A montagem resultou da "cooperação real de intenções, imaginações e experimentos de um grupo de pessoas, artistas, que se denominou criação coletiva.

\section{Fábula}

B) Montagem: En la Raya: o ensaio geral de uma peça que nunca acontece. Imagem de um país que tem a mentalidade dos “excluídos”, sempre “con os ojos postos no 
exterior”. Dirigidos por um diretor alemão, que nunca aparece, o ensaio só tem problemas. Trata-se também de uma crítica aos programas de reabilitação social dos excluídos, incluindo nela a cultura. Funciona como uma "ironia dessas pretensões de que, por meio da arte, redime-se grupos sociais marginalizados, para os quais a rendenção deveria ser outra coisa mais.

Frame:

Seqüência 1: “Abertura da peça”- 0h00m45s a 0h02m27s.

Silêncios e pausas. Entrada do personagem Ângela Vicário (Conchita). Nesse percurso inicial, ocorrem 4 pausas e posturas congeladas, aludindo à “presença” de algo; na quarta pausa, a câmera enquadra uma parte do cenário, sugerindo que há uma presença invisível e que ela está se deslocando no espaço, junto com o movimento que o personagem em cena faz acompanhando o deslocamento do ser no espaço.

Esta cena mostra o artifício do teatro para criar realidades invisíveis. No cinema de Tarkovski, a sugestão de certas imagens surge muitas vezes com uma sutileza que só a câmera pode captar como aquelas captações de superfícies refletoras como vidros, espelhos etc. O espelho, aliás, é um objeto altamente significativo. É um objeto de culto dos surrealistas, devido a, entre outras coisas, seu poder de evocar em quem o mira reflexão que remete a um tempo interior, transgredindo a lógica corrente e o tempo linear da vida cotidiana, funde passado e futuro.

Aqui, tem-se por meio dos silêncios, pausas e de paralizações corporais, sugestões que remetem a um outro tempo e espaço, povoado de sensações, percepções ainda não definidamente formuladas, um mundo de possibilidades de distintos devir.

Seqüência 2: “Canto do Hino da Colômbia”. 0h02m28s a 0h4m13s.

Aqui aplica-se também a estes personagens a idéia do grotesco cênico a que já se remeteu na peça La Orgía do TEC. O trabalho de construção dos personagens contém algo de deformante e desfigurante, mesmo que se tenha em conta o comentário de Santiago García de que eles são assim mesmo. Ao ver tais figuras cantando o hino nacional, a par de sua situação de “desechables”, comove-se. E sabe-se que isso acontece mesmo na realidade corrente. Não é difícil assistir a reportagens sobre tais grupos sociais em situações tais de celebração patriótica ou algo parecido, portar-se dessa maneira, com fervor nacionalista a cantar o hino nacional. É uma situação que provoca sensações no espectador, agita-lhe 
confusamente a alma, um misto de sentimentos o arrebata não numa absorção emocional, mas numa lucidez da consciência. Gera incômodo. Similar à cena de uma pequena orquestra de adolescentes pobre, perdidos numa cidade do sertão nordestino, empenhados na execução de uma obra de Bach, “Jesus, a alegria dos homens”, como foi mostrado certa vez no noticiário nacional.

Seqüência 3: "Passarela do casamento". 0h04m15s a 0h05m13s

Trata-se de um ritual. O gesto simples de estender uma passarela no palco alça-se a um evento importante. É a cena do casamento, que afinal, acaba também não se realizando.

Seqüência 4: “Casamento”. Oh05m15s a 0h10m05s. A representação do casamento como sendo a posse da mulher pelo homem. O noivo carrega a noiva, ela está rígida como uma boneca. O noivo faz o que quer com ela, a mulher está totalmente nas mãos do homem. Ele a carrega nos ombros, a coloca deitada no chão, a arrasta pela passarela, ela não ousa se mexer senão for pela vontade do homem. Isso no plano da encenação da peça pelos “excluídos” socialmente. Porque, no plano da relação entre os próprios integrantes dos grupos excluídos que estão atuando na peça, no programa de reabilitação, não é isso que acontece. Varias vezes o “noivo” tenta tocar na "noiva” e é fortemente repelido. O ator bebe bebida alcoólica de verdade, ao que o assistente de direção rechaça veementemente afirmando tratar-se de teatro, de mentira. Ao cabo, o diretor passa ao ensaio de outra cena sem conseguir ensaiar a do casamento até o final.

Seqüência 5: “Golpes nas portas. Silêncio e pausa”. 0h10m06s a 0h10m18s.

Outra vez, são ouvidos misteriosos golpes nas portas. O grupo dentro do galpão paraliza-se transtornado. Nunca se sabe quem golpeia as portas, mas boa coisa não é.

Seqüência 6: “Adágio de Albinoni”. A espera no cais. 0h12m33s a 0h16m05s . O quadro de uma família burguesa: o elenco veste figurinos finos que nada têm a ver com seus personagens, mas como se trata de doações vindas da Europa, pouco importa se tem a ver com a realidade dos personagens. O prestígio do diretor alemão certamente influiu para a obtenção destas doações.

Antes dessa cena, ocorre um evento bastante apreciado pelo público. Quando a caixa com os figurinos chegam, o diretor exige que o grupo tome banho antes de vestí-los, o que gera 
indignação geral. Cada um vai ao diretor para solicitar dispensa em virtude de alguma doença ou qualquer outra desculpa. Outros tentam se esconder, mas são encontrados pelo diretor que praticamente os joga banheiro adentro. Então, em seguida, aparece o grupo de homens em cuecas de um lado do banheiro masculino e o grupo das mulheres do lado oposto, das mulheres, em trajes íntimos. É uma cena hilária. O diretor vai chamando um por um e entregando-lhe o figurino novo. Saem felizes para vestir a roupa, parecem crianças recebendo um presente novo. Em seguida todos desfilam seus figurinos no meio do palco, enahamndotr vai então, de repente, depara-se com uma cena totalmente européia na frente do palco. Ao som do adágio de Albinoni, o retrato de uma família burguesa a beira do cais, a espera do navio. É uma cena ordenada e, no contexto da peça, comovente. É a ilustração de uma possibilidade de meio de vida que deveria necessariamente estar ao alcance de todos.

Seqüência 7: "Fita cassete da trilha da peça é danificada. Golpes na porta”. 0h16m06s a 0h19m31s.Assite-se aqui ao desespero do diretor ao ver a fita despedaçada por um dos atores-marginais.

Seqüência 8: Ameaça de colocar fogo no corpo. Ritual. Saída de Maritzia. Violência e morte. Sacrifício. 0h19m14s a 0h26m34s. 
FIGURA 4. Seqüência de cenas da peça Em la raya

Fonte: arquivos do grupo La Candelária

Nessa seqüência final, tem-se uma cena chocante. Uma tentativa frustrada de Santiago Nasar colcoar fogo no galpão e em si mesmo. No filme Nostalgia de Tarkovski, depara-se também com uma cena em que um homem, considerado louco, coloca fogo em seu corpo. Obviamente em outro contexto, mas chama atenção de que no filme, o personagem não só ameaça, ele o realiza e nenhuma das pessoas ao redor se mexe para impedir. Todos assistem como se fosse um espetáculo. Apenas o cachorro do homem, pressentindo o perigo, começa a latir desesperadamente. Ao contrário na montagem, embora Emma leve cruelmente uma caixa de fósforo a Santiago Nasar que se banhou de gasolina e está parado com o galão do combustível na mão, surge outro personagem Zoraya e arranca o galão de gasolina das mãos de Nasar, antes disso porém, ajoelha-se na sua frente, Conchita, e lança um pó branco para cima, criando um efeito de magia e sonho, quase um ritual.

É perceptível nas quatro montagens abordadas o sentido do sagrado. Obviamente, este sagrado é construído de forma bastante diferente em cada uma delas. Existe como distinção fundamental um ritual que é próprio do teatro, e um ritual que é o do contexto do 
tema da peça, mas que, no entanto, não deixam de se misturar e se contaminar. Estas cenas ilustram exemplares da construção poética da cena, cuja imagem principal emerge com o sentido que surge com a totalidade do espetáculo na mente do espectador segundo reflexão de Santiago García. A imagem teatral é o resultado da dialética entre a imagem construída no palco pelo encenador e a imagem percebida pelo espectador a partir da composição concreta na cena. 


\section{CONSIDERAÇÕES FINAIS}

As quatro montagens teatrais recortadas acima referem-se decisivamente à representação de fragmentos de realidades constitutivas da história das sociedades latinoamericanas. Cada uma delas deixa entrever do fundo de sua fábula o fio descontínuo de uma subjacente continuidade temático-cultural, no qual são desvendadas por sua vez tentativas, ora vãs ora bem sucedidas, de estes povos colonizados, barbaramente dominados, explicarem-se a si mesmos, de empreenderem o caminho que vai da alienação da realidade à tomada de consciência e, conseqüentemente, da busca de sua própria emancipação. As seqüências citadas são trechos de produções dramatúrgicas inscritas dentro do que se convencionou denominar "Nuevo Teatro Latino-Americano”, cujo movimento pode ser considerado a expressão última dessa linha temático-cultural, que, de forma irregular, vem costurando a história latino-americana desde tempos pré-colombianos.

Embora o "Nuevo Teatro" tenha sido objeto de muitos estudiosos, ainda se constitui em fonte inesgotável de possibilidades novas e novas abordagens que poderiam iluminar aspectos às vezes obscurecidos, às vezes simplificados, devido não só à heterogeneidade $\mathrm{e}$ complexidade do tema, mas também à "colonização cultural” e intelectual, que durante longo processo submeteu os estudiosos “locais” a defrontar sua própria realidade a partir de esquematismos de modelos teóricos europeus e norte-americanos. É sobre esta colonização intelectual que Maria Mercedes de Velasco desenvolve sua crítica abaixo:

A análise da cultura, da arte e do teatro, neste caso, na América Latina, empreendeu-se com os mesmo critérios utilizados para estudar as manifestações culturais européias. De uma perspectiva histórica, como disse José Moleón, toda a América é considerada parte do Ocidente; e de acordo com estes parâmetros normativos ocidentais se julgam os fenômenos sociais, culturais e políticos latino-americanos. Esta atitude tem sido aceita sem indícios de resistência, com poucas exceções, pelas elites que encontravam no europeu uma evasão da precária realidade de seus países. Este erro contribuiu para a confusão e a perda de identidade de muitos artistas, intelectuais e em geral das elites que têm acesso à educação e à arte. ${ }^{556}$ (1986, p.50).

\footnotetext{
${ }^{556}$ Mercedes de Velasco, Maria. Op. cit., p.50.
} 
A dominação cultural da América Latina se acentuou com o surgimento em meados do século XX da “indútria cultural” atingindo também as classes médias e as menos favorecidas economicamente, por meio das instituições de ensino, instrumento principal do Estado para a ampla difusão da cultura dominante. Processo que gera a continuidade da alienação, se se pensar no ponto de vista de Marx, segundo o qual, as pessoas já nascem alienadas. Para fazer referência a um autor latino-americano como Eduardo Galeano, dirse-á que “a alienação é o processo por meio do qual o escravo olha a si mesmo com os olhos do amo". ${ }^{557}$ Muitas vezes essa realidade da alienação não é captada facilmente pelos estudiosos “locais” mais críticos em virtude do processo de arraigamento e naturalização dessa cultura, resultado dos cinco séculos de dominação política, econômica e cultural. É preciso às vezes um sobre esforço para se dar conta desse mecanismo. Foram pontuais as personalidades latino-americanas que desde o lumiar do século XVIII reivindicaram o direito de pensar a região a partir da realidade da própria região, forjando uma conceituação própria ao buscar explanar a problemática local: José Martí, Bolívar, José Vasconcelos, Sérgio Buarque de Holanda, Gérman Arciniegas etc. Ainda que apenas no decorrer do século $\mathrm{XX}$, esse impulso de pensar a questão da identidade e da nacionalidade tenha se tornado de grande vulto, principalmente, após a Segunda Guerra.

Quando Mercedes de Velasco fala dessa elite latino-americana que buscava no europeu “uma evasão da precariedade de seus países”, essa precariedade pode ficar mais clara, ao menos em um de seus aspectos, ao tomar conhecimento de que durante a colônia até o século XIX, “o mestiço americano era considerado, por definição, o que participa dos defeitos das duas raças que lhe deram origem, sem possuir nenhuma qualidade”. ${ }^{558}$ Ou seja, além do "atraso" político e econômico, das paisagens provincianas, as populações eram totalmente desqualificadas, ignoradas e consideradas inferiores, do ponto de vista da classe dominante obviamente.

A propósito, um dos objetivos do Nuevo Teatro é justamente o empreendimento da “descolonização" mental e cultural das gentes. Finalmente, constata-se primeiro que "a cultura entronizada e promovida nos países colonizados é a cultura do colonizador”, ${ }^{559}$ e

\footnotetext{
557 “La realidad es la mejor autora de sus proprias metáforas”. El Espectador, 1986, p.5.

${ }^{558}$ Solórzano, Carlos. Teatro Latinoamericano del siglo XX, p.10.

${ }^{559}$ Mercedes de Velasco, Maria. El nuevo teatro colombiano, p.51.
} 
segundo, que desde sempre foram considerados "critérios eurocentristas e extrangeirizantes na política educativa ... sem ter em conta as necessidades reais da nação”. ${ }^{560}$ A partir de tais constatações, entre múltiplas outras, intelectuais, artistas e grupos sociais começam a integrar mobilizações históricas em busca de sua própria origem, sua própria história, enfim, de seu próprio rosto, alcançando finalmente um nível de conscientização tal que torna possível uma percepção aguda da realidade como ilustra o texto de Enrique Buenaventura citado a seguir:

Pouco a pouco fui me dando conta do que é a cultura e minha desconfiança inconsciente foi se tornando rechaço consciente. A cultura é algo preparado e elaborado na Europa e nos Estados Unidos que nós devemos tratar de vender por aqui. No que se refere ao teatro, o produto nos chega com todas as instruções para desempacotá-lo e estendê-lo ante os clientes. Há que fazer viagens, é claro, à metrópole para ver montagens, técnicas de atuação, sistemas novos de comunicação, para ficar em dia. ${ }^{561}$

Essa busca se inscreve então no marco da discussão sobre a "cultura nacional” e a "busca de identidade” que caracterizaram mobilizações de estudiosos e movimentos sociais, ambos crescentes na América Latina a partir da segunda metade do século XX.

Durante este período, a América Latina estava no “auge da moda” entre intelectuais de países centrais. Era o assunto preferido, o que deu origem à superficialidade de muitas obras estrangeiras sobre a região, em função da pressa em dar conta de acompanhar o modismo, ou, às vezes por limitação ideológica mesmo, o que não impediu de se construir acervos muito mais completos sobre a região no exterior do que em qualquer dos países latino-americanos. Isso dificulta a circulação de informações e trocas culturais entre os próprios países da região, obrigando estudiosos a irem buscar nos Estados Unidos, por exemplo, referências de estudo sobre os países vizinhos. Entre estudiosos latinoamericanistas mais recentes, contudo, é possível encontrar maior profundidade, em função do avanço no conhecimento das complexidades dos modos de vida de uma região heterogênea e multiétnica, advinda de tradição colonial.

Como o texto dramático é o único elemento perene de uma representação teatral,

\footnotetext{
${ }^{560}$ Mercedes de Velasco, Maria. Op. cit., p.50.

561 “Teatro y cultura”. In WATSON ESPENER, Maida; JOSÉ REYES, Carlos. Materiales para una historia del teatro en Colômbia, p.286.
} 
dada à efemeridade de sua própria natureza, inovar-se-á nesse trabalho ao propor o registro em vídeo ou filme como forma de manter algo do que foi a representação teatral ao vivo. Deste modo foi possível fazer referências às principais encenações de ambos os grupos, tanto a partir de registros em vídeo quanto em registros escritos, fotografados bem como de críticas publicadas, uma vez que, como dito acima, o fenômeno em si, ou seja, a encenação teatral, encerra em sua efemeridade uma irredutibilidade assentada em sua irrecuperalidade têmporo-espacial.

Para uma primeira abordagem, destaca-se o fato de as cenas se referirem a fatos históricos concretos. A primeira cena está vinculada a um ciclo de peças relacionadas à história recente da Colômbia e representa mais precisamente um esforço de compreensão do período que ficou conhecido como “os anos da violência”, em vigor na Colômbia do final dos anos 40 a meados dos anos 50 do século XX. A segunda cena remonta a um evento histórico da segunda metade do século XIX, chamado de "Revolução dos Comuneros”, no final do período colonial. E aqui está apontada a primeira relação concreta que une estas duas cenas, a saber, o empenho no trato com a História. O esforço conjunto para reelaborar uma história que não só desafia a Historia Oficial, da classe dominante, mas que também é proposta a partir da consideração de novos pontos de vista, justamente daqueles ignorados e forçados ao silêncio.

A partir da violência e da barbárie da Conquista, as sociedades da América Latina foram se configurando sob o signo da fragmentação, o que gerou desde sua origem a busca pela unidade do Ser. O alcance da criação de imagens poéticas produzidas no contexto do movimento do Nuevo Teatro na segunda metade do século XX revelou um relativo amadurecimento desta busca. Representou não um ponto de chegada propriamente dito, mas uma aproximação ao reconhecimento do que significou, significa e significará ser latino-americano. 


\section{BIBLIOGRAFIA}

\section{Obras de e sobre Enrique Buenaventura e o Teatro Experimental de Cali}

BUENAVENTURA, Enrique. Los Papeles del Infierno y otros textos. Bogotá, Siglo Veintiuno, 1990.

BUENAVENTURA, Enrique. Máscaras y Ficiones. Cali, Colômbia: Universidad del Valle, 1992.

BUENAVENTURA, Enrique. “A arte não é um luxo”.

BUENAVENTURA, Enrique. "Teatro e cultura”. In WATSON ESPENER, Maida;

BUENAVENTURA, Enrique. Poemas e cantares. MERCEDES JARAMILLO, Maria;

OSORIO, Betty; YEPES, Mario (Editores). Obra completa. vol. 1. Cali, Medellín:

Universidad del Valle, Universidad de Antioquia, 2004.

BUENAVENTURA, Enrique. Teatro Inédito. Bogotá, Presidente de la República, 1997. BUENAVENTURA, Enrique. Diario de Trabajo: 1984-1987. Cali, Colômbia: TEC, 2007, p.71. Obra sem publicação, cedida pela atual diretora do TEC, Jacqueline Vidal, [Digitada]. BUENAVENTURA, Enrique. "La interpretacion de los sueños y la improvisacion teatral”. In WATSON ESPENER, Maida; CARLOS REYES, José. Materiales para una historia del teatro en Colômbia.

JOSEFINA CASAS, Vésper. Trás las Máscaras del Teatro. Arte y Política: un análisis desde "La denuncia”. Obra del Teatro Experimental de Cali. Popayán, Universidad del Cauca, 2002.

MAZA CHAMARRO, Tânia. "Enrique Buenaventura: o la suma elegíaca del teatro colombiano”. Home Page: http://casadeasterion.homestead.com/v5n19buena.html; capturado da Internet em 31/05/2006.

MERCEDES JARAMILLO, Maria; OSORIO, Betty. "El legado de Enrique Buenaventura”. In Revista de Estudios Sociales, no. 17, febrero de 2004.

RIZK, Beatriz J. Buenaventura: la Dramaturgia de la Creación Colectiva. México, Editorial Gaceta, 1991.

RIZK, Beatriz J. "La obra de Enrique Buenaventura”. In Separata Dramaturgica. Bogotá, Escuela Nacional de Arte Dramático, Cocultura, 1996.

VÁZQUEZ-ZAWADZKI, Carlos. "El teatro de Enrique Buenaventura y la afirmación popular”. Site: http://www.revista.agulha.nom.br/ag33buenaventura.htm. Acesso em 01 de outubro de 2006.

\section{Obras de e sobre Santiago Garcia e o Teatro La Candelária}

ESPINOSA DOMÍNGUEZ, Carlos. "La Candelaria: vivir para el teatro”. In: Escenarios de dos mundos: inventario teatral de Iberoamérica, vol.1, Madrid: Centro de Documentación Teatral, 1988.

GARCIA, Santiago. Teoria e prática do teatro. São Paulo: Hucitec, 1988. 
GARCIA, Santiago. Teoría y práctica del teatro. vol. 2, Bogotá, Ediciones Teatro La Candelária, 2002.

GARCIA, Santiago. Teoría y práctica del teatro. vol. 3. Bogotá, Ediciones Teatro La Candelária, 2006.

DUQUE MESA, F.; PRADA PRADA, Jorge. Santiago García: el Teatro como Coraje. Bogotá, Investigación Teatral Editores, 2004.

\section{Sobre o teatro na Colômbia}

ARCILA, Gonzalo. Nuevo Teatro en Colômbia. Bogotá, Ediciones CEIS,1983.

AZCÁTE, Pablo. "El Nuevo Teatro y la CCT” In: Materiales para una historia del teatro em Colômbia.

BAYCROFT, Bernard Kent. Brecht in Colômbia: The Rise if the New Theatre. Michigan, Stanford University, 1986.

CARLOS REYES, José. Materiales para una historia del teatro en Colômbia. Bogotá, Instituto Colombiano de Cultura, 1986.

GIORGIO ANTEI (Editor). Las Rutas del teatro. Bogotá: Universidad Nacional de Colômbia, 1989.

GOMÉZ, Eduardo.“Notas sobre la iniciación del teatro moderno em Colombia”. In: GOMÉZ, Eduardo. "La influencia de Brecht en el teatro moderno en Colombia”. In Señales Abiertos, octubro-diciembre de 1992, pp.25-37.

GONZÁLEZ CAJIAO, Fernando. Historia del Teatro en Colômbia, 1986

MERCEDES JARAMILLO, Maria. El nuevo teatro colombiano y la colonización cultural. 1986.

MERCEDES JARAMILLO, Maria. "La autonomia cultural en el teatro colombiano”. http://iacd.oas.org/interamer/Interamerhtml/RodrVerghtml/Verg34_Jaram.htm, acesso em 02/01/20007.

RIZK, Beatriz J. El Nuevo Teatro Latinoamericano: una lectura histórica. Minneapolis, Prisma Institute, 1987.

WATSON ESPENER, Maida; JOSÉ REYES, Carlos. Materiales para una historia del teatro en Colômbia.

\section{Bibliografia geral}

ALVAREZ, Sonia E.; DAGNINO, Evelina; ESCOBAR, Arturo (Org.). Cultura e Política nos movimentos sociais latino-americanos. Belo Horizonte, UFMG, 2000.

AIRA, César. Dicionário de Autores Latinoamericanos. Buenos Aires, Emecé, 2001. América Ladina: Germán Arciniegas. México, Fondo de Cultura Econômica, 1993.

Compilador Juan Gustavo Cobo Borda, coleção Tierra Firme.

BENJAMIM, Walter. "Magia e técnica, arte e política” In: Obras escolhidas. 7 ed. São Paulo: Brasiliense, 1994.

BOAVENTURA, Maria Eugênia. A vanguarda antropofágica. São Paulo: Ática, 1985. BONETT, Diana. "Estalla la Revuelta de los comuneros". In.: http://www.colombiamania.com/historia/ 
index_historia/04_las_fundaciones_y_poblamiento/0010_revuelta_comuneros.html, acesso em 18/01/07.

BOURDIEU, Pierre. As regras da arte: gênese e estrutura do campo literário. São Paulo: Companhia das Letras, 1996.

BOURDIEU, Pierre. A economia das trocas simbólicas. 5ª Ed. São Paulo: Perspectiva, 2004.

BRANDING, D. A. “A Espanha dos Bourbons e seu Império Americano”. In BETHELL, Leslie (org.). História da América Latina: A América Latina Colonial I, vol.1, São Paulo: Edusp; Brasília, DF: Fundação Alexandre Gusmão, 1998.

CARELLA, Túlio. El Sainete, Buenos Aires: Centro Editor de América Latina, 1967.

BÜRGER, Peter. Teoria da Vanguarda. Lisboa: Vega, 1993.

CAMACHO, Ricardo. “La 'creación' y la crisis de autores en el teatro nacional. In:

CAMACHO GUIZADO, Eduardo. Sobre la literatura colombiana e hispanoamericana.

1977.

CID PERÉZ, José; MARTI CID, Dolores. Teatro Indio Precolombino. Madrid: Aguilar, 1964.

COSTA, Iná Camargo. Sinta o drama. Petrópolis, RJ: Vozes, 1998, 237p.

COULON, Olga Maria A. Fonseca; Pedro, Fábio Costa. "Dos Estados Nacionais à Primeira Guerra Mundial”, 1995, CP1-UFMG. Site:

http://www.hystoria.hpg.ig.com.br/rindus01.html; Acesso em 10/07/2006.

EAGLETON, Terry. A ideologia da Estética. Rio de Janeiro, Zahar, 1993.

SADER, E.; JINKINGS, I. (Coord.). Enciclopédia Contemporânea da América Latina e do Caribe. Rio de Janeiro/São Paulo, Laboratório de Políticas Públicas, Boitempo, 2006.

FORSTER, Merlin H. Latin American Theatre Review. Kansas, Universidade de Kansas, $\mathrm{N}^{\mathrm{0}} 1 / 1$, Fall 1967. pp. 50-54.

GARCIA CANCLINI, Néstor. A produção simbólica: teoria e metodologia em sociologia da arte. Rio de Janeiro, Civilização Brasileira, 1979.

GIBSON, Michael. Simbolismo. Concepção: Gilles Néret. Colônia, Alemanha: Taschen, 2006.

GONZÁLES, Margarita. El resguardo en el nuevo reino de granada. Bogotá, La Carreta Inéditos Ltda, 1979.

GONZÁLEZ-RÚBIO, Mar Estela. “El grupo ‘Mito’ y las Vanguardias en Colômbia”. In www.ucm.es/info/especulo/numero28/mitocol.html.

GULLAR, FERREIRA. Vanguarda e subdesenvolvimento. Rio de Janeiro: Civilização Brasileira, 1969.

HERMAN, Edward S.; CHOMSKY, Noam. A manipulação do público. São Paulo: Futura, 2003.

LYNTON, Norbert. "Expressionismo”. In: Conceitos da arte moderna. STANGOS, Nikos (Editor). Rio de Janeiro: Jorge Zahar, 2000.

KOVAL, Boris. A grande Revolução de Outubro e a América Latina. São Paulo: AlfaÔmega, 1980.

MARX, Karl. Para a Crítica da Economia Política. São Paulo, Abril Cultural, 1982.

PAVIS, Patrice. Dicionário de Teatro. São Paulo: Perspectiva, 2005.

PAZ, Otávio. O labirinto da solidão e post-scriptum. Rio de Janeiro: Paz e Terra, 1984. PINCÓN-VALLIN, Béatrice. A arte do teatro: entre tradição e vanguarda. Meyerhold e a cena contemporânea. Rio de Janeiro: Teatro do Pequeno Gesto: Letra e Imagem, 2006. 
POSADA, Francisco. Lúkács, Brecht e a situação do realismo socialista. Rio de Janeiro, Civilização Brasileira, 1970.

REYES, José Carlos. “1955-1987: um movimiento plural e creciente” In Escenarios de dos mundos.

RIZK, Beatriz J. Posmodernismo y teatro en América Latina: Teorías y prácticas en el umbral del siglo XXI. Madrid: Iberoamericana, 2001.

ROSENFELD, Anatol. O teatro épico.

SAGAN, Carl. Cosmos. Rio de Janeiro, Francisco Alves, 1989.

SCHWARTZ, Jorge. Vanguardas Latino-Americanas: polêmicas, manifestos e textos críticos. São Paulo: Editora da Universidade de São Paulo: Iluminuras: FAPESP, 1995. SOLÓRZANO, Carlos. Teatro Latinoamericano del siglo XX.

SOLÓRZANO, Carlos. “Corrientes del Teatro Latinoamericano”. In Latin American Theatre Review, Kansas, n. 2/1, p. 59-60, Fall 1968.

SZONDI, Peter. Teoria do drama moderno [1880-1950]. São Paulo: Cosac \& Naify, 2001. TARKOVSKI, Andrei. Esculpir o tempo. São Paulo: Martins Fontes, 1990.

TAYLOR, Diana. Theatre of crisis. Drama and politics in Latin American. Kentucky: University of Kentucky, 1991.

YOSHIKAWA Emiko. “El magisterio latinoamericano de Seki Sano” In: Escenarios de dos mundos.

WATSON ESPENER, Maida; JOSÉ REYES, Carlos. Materiales para una historia del teatro en Colômbia.

WATSON ESPENER, Maida. "La teoria teatral de Enrique Buenaventura”. In WATSON ESPENER, Maida; CARLOS REYES, José. Materiales para una historia del teatro en Colômbia.

WEISS, Judith A . Latin American Popular Theatre. Albuquerque, University of New Mexico Press, 1993.

WHITFIELD, Sara. "Fauvismo”. In.: Conceitos da arte moderna. STANGOS, Nikos (Editor). Rio de Janeiro: Jorge Zahar, 2000.

ZEA, Leopoldo.“América Latina: largo viaje hacia si misma”. In: Ideas em torno de latinoamerica.

CARTER, Huntly. The new spirit in the russian theatre: 1917-1928. New

York/Londres/Paris, Bretano’s, 1924.

CONRADO, Aldomar. O teatro de Meyerhold. Rio de Janeiro, Civilização Brasileira, 1969.

GUINSBURG, J. Stanislávski, Meyerhold \& Cia. São Paulo, Perspectiva, 2001.

LEACH, Robert. Vesevolod Meyerhold. 1989.

EYERHOLD, V. Teoria teatral. 5aed., Madrid, Editorial Fundamentos, 1986.

RUDNITSKY, Konstantin. Meyerhold: the director. Translated by George Petrov; Edited by Sydney Schultze; Introduction by Ellendea Proffer. Michigan-Ann Arbor, Ardis, 1981, 565 p. [1 $1^{\mathrm{a}}$.edição em russo 1969].

SCHMIDT, Paul (Ed.). Meyerhold at work. Austin, University of Texas Press, 1980.

SYMONS, J. Meyerhold's Theater of the Grotesque. Florida, University of Miami Press, 1971. 


\section{Materiais especiais}

Filmes e vídeos, cópias em DVD.

NEL REY, Pedro. TEC en Paris -1971: Trilogia Teatral. [Filme]. Cali, Colômbia, s.d., Cópia em dvd.

Enrique Buenaventura. Versão livre para TV. Cópia de dvd.

Crônica. Montagem do TEC, gravada em vídeo, s.d. Cópia em dvd.

El lunar em la fuente. Montagem do TEC, gravada em vídeo, s.d. Cópia em dvd.

Guinnaru. Montagem do TEC, gravada em vídeo, s.d. Cópia em dvd.

Los Dientes de la Guerra. Montagem do TEC, gravada em vídeo, s.d. Cópia em dvd.

CANDELÁRIA: 40 ANOS. Documentário feito pela TV [Vídeo]. Bogotá, 2006. 120min. Cópia em dvd.

\section{Filmes}

NORDEN, Francisco. Condores no entierran todos los dias. [Filme]. Bogotá, Colômbia, 1984. 90min, color. son. Cópia em dvd.

EISENSTEIN, S. Alexandre Nevsky. [Filme]. Moscou/URSS, 1938. 108min, p\&b, son. TARKOVSKI, A. O Espelho. [Filme]. Rússia/URSS, Mosfilm, 1974. 101min, color., son. TARKOVSKI, A. Nostalgia. [Filme]. Roma, Sovin Film e Raí 2 TV, 1983.121min., color., son. 


\section{ANEXO 1}

\section{Dados oficiais da Colômbia}

Nome oficial: República de Colômbia

Localização: Norte da América do Sul, banhada pelo mar do Caribe entre o Panamá e a Venezuela e pelo oceano Pacífico norte, entre o Equador e o Panamá.

Estado: República presidencialista

Idioma: Espanhol

Moeda: Peso colombiano

Capital: Bogotá (6 milhões de hab. Em 1999)

Superfície: $1.138 .910 \mathrm{~km} 2$.

População: 45,60 milhões (2005)

Densidade demográfica: 40 hab./km2 (2005)

Distribuição da população: Urbana (77,4\%) / Rural (22,6\%) (2005).

Analfabetismo: 7,1\% (2005)

Composição étnica: Mestiços de brancos, ameríndios e negros (58\%); brancos (20\%); mestiços de brancos e negros (14\%); negros (4\%); mestiços de brancos e ameríndios (3\%); ameríndios (1\%).

Religiões: Católica romana (90\%); outras (10\%).

PIB (a preços constantes de 1995): US $\$ 104,8$ bilhões (2003)

PIB per capita (a preços constantes de 1995): US\$ 2.352,4 (2003)

Dívida externa bruta desembolsada: US $\$ 37,3$ bilhões (2002)

IDH: 0,785 (2003)

IDH no mundo e na AL: $69^{\circ}$. e $15^{\circ}$.

Eleições: Legislativo bicameral composto pelo Senado de 102 membros e pela Câmara de Representantes de 163 membros. Eleições a cada 4 anos.

Fonte: Latinoamericana: enciclopédia contemporânea da América Latina e do Caribe.

Coordenadores: Emir Sader, Ivana Jinkings, Rodrigo Nobile, Carlos Eduardo Martins. Rio de janeiro, São Paulo: Laboratório de Políticas Públicas da UERJ, Boitempo, 2006, p.322. 


\section{ANEXO 2}

\section{Colômbia - Uma história de guerras}

1899/1903 - Primeira guerra civil entre liberais e conservadores (os dois partidos burgueses e oligarcas que dominam a política tradicional do país): "Guerra dos Mil Dias". A guerra termina com um acordo entre os dois lados, diante da ameaça de intervenção dos Estados Unidos. Inicia-se um período de 30 anos de governos conservadores.

1946 - Nas eleições presidenciais, o partido liberal se divide em duas alas. Uma refletia a pressão das lutas populares, e tinha como candidato Jorge Eliécer Gaitán, a outra apoiava Gabriel Turbay. Aproveitando-se da divisão o Partido Conservador ganha as eleições, elegendo Mariano Ospina Pérez

1948 - Assassinado Jorge Eliécer Gaitán. Como reação à sua morte explode a rebelião popular conhecida como o "Bogotazo". Em seguida começa "A violência", uma guerra civil que durou 10 anos, onde se enfrentam as guerrilhas liberais e comunistas com o governo conservador.

1959 - A Revolução Cubana tem uma grande influência sobre o renascimento do movimento guerrilheiro.

1962 - O exército inicia uma ofensiva contra a zona liberada controlada pelos comunistas em Marquetalia, departamento de Tolima (região central, próxima a Bogotá). Os camponeses reagem com ações guerrilheiras. Um dos camponeses desta zona era Manuel Marulanda Vélez, o "Tirofijo" (hoje, principal dirigente das FARC).

1964 - As guerrilhas comunistas se reúnem em Marquetalia, em 20 de julho de 1964 e aprovam um programa de reforma agrária revolucionária que tem como base o "confisco da propriedade latifundiária" e das "ocupadas por companhias imperialistas". O Exército expulsa a guerrilha de Marquetalia.

1966 - A guerrilha comunista de Marquetalia, em unidade com outros destacamentos guerrilheiros do sul de Tolima, funda as Forças Armadas Revolucionárias da Colômbia (FARC).

1967 - Surge o Exército de Libertação Nacional, inspirado em Che Guevara. O Partido Comunista Colombiano - Marxista-Leninista (PCC-ML) organiza o Exército Popular de Libertação. Essas duas guerrilhas refletem o ascenso do movimento estudantil dos anos 60 e as massas urbanas empobrecidas.

1970 - Eleito Misael Pastrana Borrero, conservador, com 1,6 milhão de votos. O ex-ditador e general Gustavo Rojas Pinilla, líder da Aliança Nacional Popular (Anapo), consegue 1,5 milhão de votos. Há acusações generalizadas de fraude e descontentamento das massas pobres que tinham votado em Rojas Pinilla. 
1973 - Surge o Movimento 19 de Abril (M-19), uma guerrilha de tipo nacionalista e popular. O movimento vem das fileiras da Anapo.

1984 - Em março o governo firma uma trégua de um ano com as FARC. Em 24 de agosto é firmado um acordo com o M-19 e com o Exército Popular de Libertação (EPL). Poucos meses depois o M-19 rompe o cessar-fogo devido às agressões constantes do Exército.

1986 - Toma posse o presidente Virgílio Barco, do Partido Liberal. Nestas eleições a União Patriótica, movimento orientado pelo Partido Comunista e ligado às FARC, concorre e obtém mais de 300.000 votos.

1987 - Os grupos paramilitares (extrema-direita) começam um plano sistemático de assassinatos, não só de guerrilheiros mas de dirigentes políticos e sindicais. Jaime Pardo Leal, o candidato a presidente e máximo dirigente da União Patriótica, é assassinado por mercenários paramilitares o que provoca uma onda de enfrentamentos entre as massas e a polícia com o saldo de oito mortos.

1989 - Um comando assassina Luís Galán, pré-candidato liberal às eleições presidenciais que aparecia com maiores chances de vitória. O governo do presidente Barco desfecha uma campanha militar contra os narcotraficantes, que respondem com atentados, bombas e até lançamento de mísseis.

1990 - O M-19, que renunciara a luta armada em 1989, obtém 19 cadeiras na Constituinte.

1991 - O EPL também renuncia a luta armada após acordo com o governo.

1994 - Assume o presidente eleito Ernesto Samper do Partido Liberal. Explode o escândalo do apoio financeiro do narcotráfico à campanha de Samper.

1998 - Eleito Andres Pastrana e início do processo de aproximação e tentativa de negociação com as duas guerrilhas que continuam ativas no país: as FARC e o ELN.

2002 - Álvaro Uribe Vélez é eleito presidente, seu governo é marcado por um regime autoritário e uma explícita “orientação ideológica” na adoção acelerada “das tarefas agendadas da nova ordem neoliberal”. "A articulação com o império e seu principal agente, os EUS, é absoluta”. (Enciclopédia Latinoamericana, p.336).

\section{Anexo 3}

\section{FESTIVAIS DE TEATRO NA COLÔMBIA}

1968 - FESTIVAL NACIONAL DE TEATRO UNIVERSITÁRIO

Cali - 4-9 set 


\begin{tabular}{|c|c|c|c|}
\hline Título & Autor & Diretor & Grupo \\
\hline $\begin{array}{l}\text { Guárdese bien cerrado en un } \\
\text { lugar seco y fresco } \\
\text { Guadalupe Terreros }\end{array}$ & $\begin{array}{l}\text { Megan Terry } \\
\text { Fanor Terán }\end{array}$ & Danilo Tenorio & $\begin{array}{c}\text { Universidad Santiago } \\
\text { de Cali }\end{array}$ \\
\hline El museo & Guillermo Borrero & Guillermo Borrero & Universidad del Cauca \\
\hline $\begin{array}{l}\text { La condena de Lucullus } \\
\text { Aguante Aguantín }\end{array}$ & $\begin{array}{l}\text { Bertolt Brecht } \\
\text { Hugo Villegas }\end{array}$ & Hugo Villegas & Universidad de Caldas \\
\hline $\begin{array}{l}\text { El globo } \\
\text { Em algún lugar es de noche }\end{array}$ & $\begin{array}{l}\text { Fernando González Cajiao } \\
\text { Ignácio Gómez Dávila }\end{array}$ & Antonieta Mercury & $\begin{array}{c}\text { Universidad } \\
\text { Tecnológica de Pereira }\end{array}$ \\
\hline $\begin{array}{l}\text { Um solo de saxofon } \\
\text { Episodio de la vida universitaria }\end{array}$ & $\begin{array}{l}\text { A . Muniz } \\
\text { Grupo de Teatro - U. Libre }\end{array}$ & $\begin{array}{l}\text { Manuel H. Edmont } \\
\text { Rojas }\end{array}$ & $\begin{array}{c}\text { Universidad Libre de } \\
\text { Colombia }\end{array}$ \\
\hline $\begin{array}{l}\text { Los viejos baúles empolvados } \\
\text { que nuestros padres nos } \\
\text { prohibieron }\end{array}$ & Carlos José Reys & Carlos José Reys & $\begin{array}{c}\text { Universidad Externado } \\
\text { de Colombia }\end{array}$ \\
\hline
\end{tabular}

Bogotá - 18-24 set

\begin{tabular}{|c|c|c|c|}
\hline Título & Autor & Diretor & Grupo \\
\hline $\begin{array}{l}\text { La autopsia } \\
\text { El Knack }\end{array}$ & $\begin{array}{l}\text { Enrique Buenaventura } \\
\text { Ann Jellicoe }\end{array}$ & Ricardo Camacho & $\begin{array}{l}\text { Universidad de los } \\
\text { Andes }\end{array}$ \\
\hline $\begin{array}{l}\text { La sombra del valle } \\
\text { Las diligencias }\end{array}$ & $\begin{array}{l}\text { John Millington Synge } \\
\text { Héctor Sánchez }\end{array}$ & Héctor Sánchez & $\begin{array}{l}\text { Universidad la Gran } \\
\text { Colombia }\end{array}$ \\
\hline $\begin{array}{l}\text { Enrique IV } \\
\text { Nascimento de la verdad } \\
\text { números y variedades }\end{array}$ & $\begin{array}{l}\text { Luigi Pirandello } \\
\text { Joel Otero }\end{array}$ & Joel Otero & $\begin{array}{l}\text { Universidad Nacional } \\
\text { de Colombia }\end{array}$ \\
\hline $\begin{array}{l}\text { Ceremonia para um negro } \\
\text { asesinado } \\
\text { Un hongo nació em Hiroshima }\end{array}$ & $\begin{array}{l}\text { Fernando Arrabal } \\
\text { Gabriel Brasso }\end{array}$ & Gabriel Brasso & $\begin{array}{l}\text { Universidad del } \\
\text { Atlântico }\end{array}$ \\
\hline $\begin{array}{l}\text { Outra vez un extraño há llegado } \\
\text { a nuestros predios }\end{array}$ & $\begin{array}{l}\text { Enrique Pulecio } \\
\text { Luis Alberto García } \\
\text { Jiménez }\end{array}$ & $\begin{array}{l}\text { Luis Alberto } \\
\text { García Jiménez }\end{array}$ & $\begin{array}{l}\text { Fundación Universidad } \\
\text { de América }\end{array}$ \\
\hline
\end{tabular}

Medellín - 29 set -04 out

\begin{tabular}{|c|c|c|c|}
\hline Título & Autor & Diretor & Grupo \\
\hline $\begin{array}{l}\text { El Rabdomante } \\
\text { La requisa }\end{array}$ & $\begin{array}{l}\text { Sebastián Salazar Bondy } \\
\text { Enrique Buenaventura }\end{array}$ & Edilberto Gómez & $\begin{array}{l}\text { Universidad de } \\
\text { Antioquia }\end{array}$ \\
\hline Maluco el Bejuco & Guillermo Valencia Salgado & $\begin{array}{l}\text { Guillermo Valencia } \\
\text { Salgado }\end{array}$ & $\begin{array}{l}\text { Universidad de } \\
\text { Córdoba }\end{array}$ \\
\hline $\begin{array}{l}\text { Las bodas de lata, o } \\
\text { El baile de los arzobispos }\end{array}$ & Jairo Aníbal Niño & Jairo Aníbal Niño & $\begin{array}{l}\text { Universidad Nacional } \\
\text { Seccional de Medellín }\end{array}$ \\
\hline $\begin{array}{l}\text { La farsa de Maese Pedro } \\
\text { Pathelin } \\
\text { El dia de la ira }\end{array}$ & $\begin{array}{l}\text { Anônimo } \\
\text { Oscar Jurado }\end{array}$ & Henry Cardona & $\begin{array}{l}\text { Univesidad Nacional } \\
\text { Seccional de } \\
\text { Manizales }\end{array}$ \\
\hline $\begin{array}{l}\text { Escena para cuatro personajes } \\
\text { Misa para el tiempo futuro. } \\
\text { Ceremonia }\end{array}$ & $\begin{array}{l}\text { Eugene Ionesco } \\
\text { Alberto Sierra }\end{array}$ & Alberto Llerena & $\begin{array}{l}\text { Universidad de } \\
\text { Cartagena }\end{array}$ \\
\hline En la diestra de Dios Padre & Enrique Buenaventura & $\begin{array}{l}\text { Yolanda García } \\
\text { Reina }\end{array}$ & $\begin{array}{l}\text { Universidad Pontifica } \\
\text { Bolivariana }\end{array}$ \\
\hline
\end{tabular}


\begin{tabular}{|l|l|l|l|}
\hline & & & \\
\hline
\end{tabular}

* Esta tabela dos festivais de teatro da Colômbia será completada até a data de 1975. 